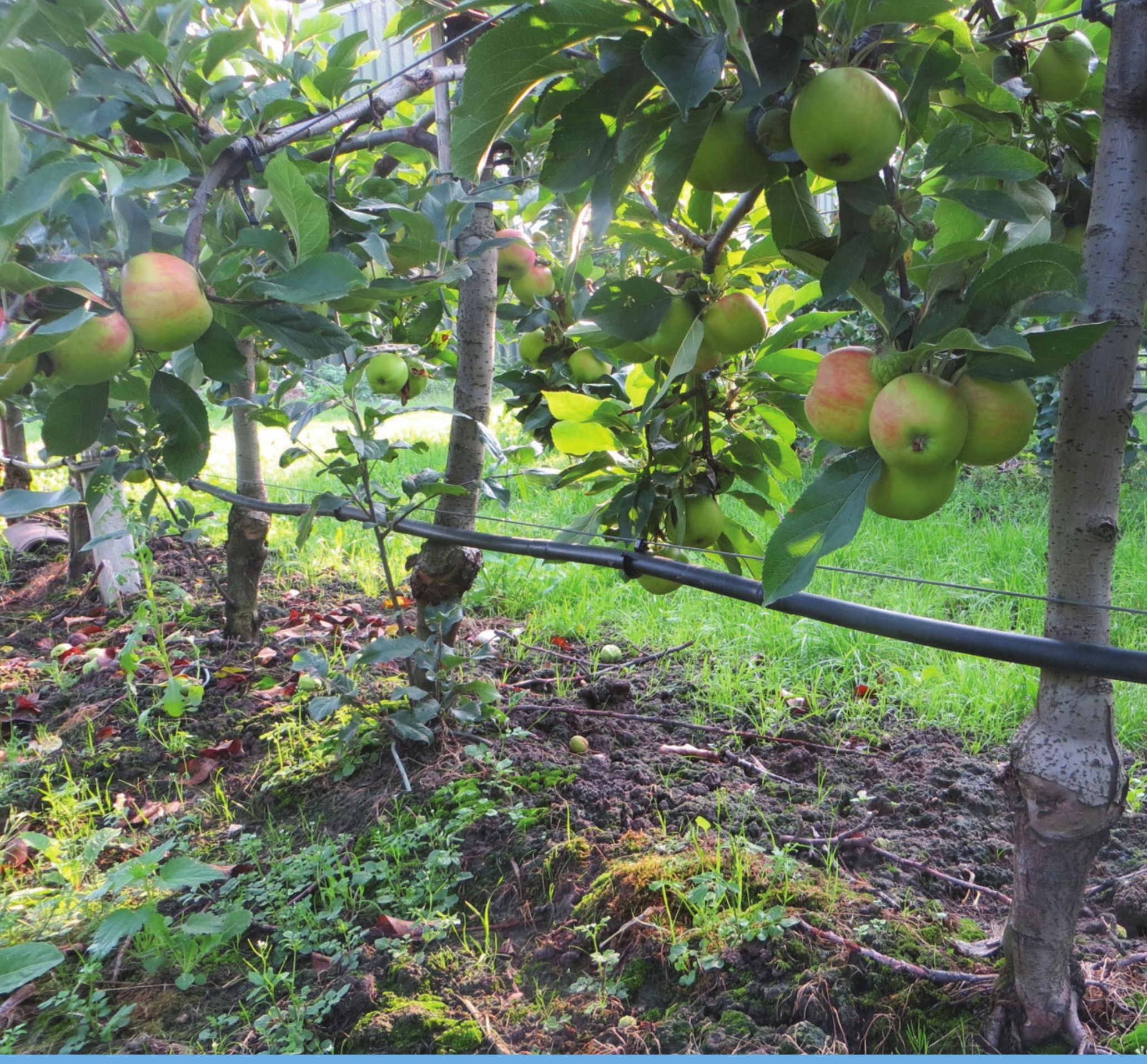

\title{
Inventarisatie en analyse zouttolerantie van landbouwgewassen op basis van bestaande gegevens
}

L C P M Stuyt, M Blom-Zandstra en R A L Kselik

WAGENINGEN

UNIVERSITY \& RESEARCH 



\section{Inventarisatie en analyse zouttolerantie van landbouwgewassen op basis van bestaande gegevens}

L C P M Stuyt ${ }^{1}$, M Blom-Zandstra² en R A L Kselik ${ }^{1}$

1 Wageningen Environmental Research (Alterra)

2 Wageningen Plant Research

Dit onderzoek is uitgevoerd door Wageningen Environmental Research (Alterra) in opdracht van en gefinancierd door Rijkswaterstaat Water, Verkeer en Leefomgeving.

Wageningen Environmental Research

Wageningen, oktober 2016

Rapport 2739

ISSN 1566-7197 
L C P M Stuyt, M Blom-Zandstra, R A L Kselik, 2016. Inventarisatie en analyse zouttolerantie van landbouwgewassen op basis van bestaande gegevens. Wageningen, Wageningen Environmental Research, Rapport 2739. 158 blz.; 20 fig.; 7 tab.; 125 ref.

Referaat - In het Deltaprogramma Zoetwater is het lastig gebleken economische analyses te maken voor de programmering van maatregelen en/of de beleidsmatige afweging rond waterbeschikbaarheid. Een van de knelpunten is het gemis aan inzicht in de droogte- en zoutschade in landbouw en natuur. De zoutschade aan landbouwgewassen is nog niet goed in beeld; er zijn veel getallen in omloop, maar de manier waarop deze tot stand zijn gekomen en/of gerapporteerd is niet eenduidig. Daarom is de tussen 1950 en 2015 in Nederland beschikbaar gekomen informatie geanalyseerd. Het resultaat is specificatie van zouttolerantiedrempels voor 35 gewassen en gewasgroepen, gekoppeld aan het zoutgehalte van beregeningswater.

Summary - In the Dutch Delta Programme Fresh Water, the development of adequate strategic and operational measures to meet service levels of fresh water supply to agriculture has proved difficult. One of the problems is a limited knowledge of drought-, and salt damage to agricultural crops. Over the years, many figures have been proposed, yet the way these were established is ambiguous. Hence information that has become available in the Netherlands between 1950 and 2015 has been analysed and summarized. The result of is a concise specification of so called salt tolerance thresholds of 35 (groups of) crops, linked to the irrigation water salinity.

Trefwoorden: zout, verzilting, zoetwaterbeheer, zouttolerantie, zouttolerantiedrempel, landbouwgewassen.

Dit rapport is gratis te downloaden van http://dx.doi.org/10.18174/391931 of op www.wur.nl/environmental-research (ga naar 'Wageningen Environmental Research' in de grijze balk onderaan). Wageningen Environmental Research verstrekt geen gedrukte exemplaren van rapporten.

2016 Wageningen Environmental Research (instituut binnen de rechtspersoon Stichting Wageningen Research), Postbus 47, 6700 AA Wageningen, T 03174807 00, E info.alterra@wur.nl, www.wur.nl/environmental-research. Wageningen Environmental Research is onderdeel van Wageningen University \& Research.

- Overname, verveelvoudiging of openbaarmaking van deze uitgave is toegestaan mits met duidelijke bronvermelding.

- Overname, verveelvoudiging of openbaarmaking is niet toegestaan voor commerciële doeleinden en/of geldelijk gewin.

- Overname, verveelvoudiging of openbaarmaking is niet toegestaan voor die gedeelten van deze uitgave waarvan duidelijk is dat de auteursrechten liggen bij derden en/of zijn voorbehouden.

Wageningen Environmental Research aanvaardt geen aansprakelijkheid voor eventuele schade voortvloeiend uit het gebruik van de resultaten van dit onderzoek of de toepassing van de adviezen.

Wageningen Environmental Research Rapport 2739 | ISSN 1566-7197

Foto omslag: Lodewijk Stuyt 


\section{Inhoud}

$\begin{array}{ll}\text { Woord vooraf } & 5\end{array}$

$\begin{array}{ll}\text { Samenvatting } & 7\end{array}$

$\begin{array}{llr}1 & \text { Inleiding } & 9\end{array}$

1.1 Achtergrond 9

1.2 Probleem- en doelstelling 9

$\begin{array}{ll}1.3 \text { Werkwijze en beoogd resultaat } & 11\end{array}$

2.1 Inleiding 12

2.2 Effect van zout in de bodem op gewasgroei en -opbrengst 13

$\begin{array}{lll}2.3 & \text { Chronologisch overzicht } & 14\end{array}$

2.4 Irrigatie- en zoutschade $\quad 21$

$\begin{array}{lll}2.5 & \text { Structuurbederf } & 22\end{array}$

2.6 Zoutschadedrempels $\quad 23$

$\begin{array}{lll}2.7 & \text { Simulatiemodel SWAP } & 24\end{array}$

$\begin{array}{lll}2.8 & \text { De beregening van landbouwgewassen } & 27\end{array}$

3 Inventarisatie zoutschade op basis van bestaande gegevens 29

$\begin{array}{lll}3.1 & \text { Inleiding } & 29\end{array}$

$\begin{array}{lll}3.2 & \text { Beschrijving werkwijze } & 30\end{array}$

$\begin{array}{lll}3.3 & \text { Betrouwbaarheidsintervallen van drempelwaarden } & 34\end{array}$

$\begin{array}{lll}3.4 & \text { Analyse en discussie } & 38\end{array}$

$4 \quad$ Conclusies en aanbevelingen $\quad 44$

$5 \quad$ Zouttoleranties van 35 gewassen en gewasgroepen $\quad 47$

$\begin{array}{lll}5.1 & \text { Grasland } & 48\end{array}$

5.2 Tarwe, gerst $\quad 51$

5.3 Klaver (Luzerne) $\quad 54$

5.4 Snijmais $\quad 56$

5.5 Radijs, spinazie, erwten, bonen $\quad 59$

5.6 Spruiten, witlof, boerenkool, radijs $\quad 62$

$\begin{array}{lll}5.7 & \mathrm{Ui} \text {, andijvie, knolselderij, prei, wortelen, witlof } & 65\end{array}$

$\begin{array}{lll}5.8 & \text { Aubergine, aardbei, tuinbonen } & 68\end{array}$

$\begin{array}{lll}5.9 & \text { Aardappel } & 71\end{array}$

$\begin{array}{ll}5.10 \text { Augurk } & 74\end{array}$

$\begin{array}{ll}5.11 \text { Broccoli } & 77\end{array}$

$\begin{array}{ll}5.12 \text { Erwten } & 79\end{array}$

$\begin{array}{ll}5.13 \text { Knolselderij } & 82\end{array}$

$\begin{array}{ll}5.14 & \text { Kroot (rode biet) } \\ 5.15 & 85\end{array}$

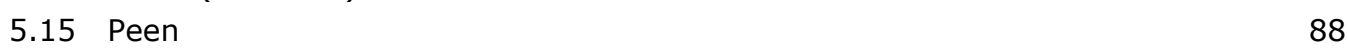

$\begin{array}{ll}5.16 \text { Prei } & 91\end{array}$

$\begin{array}{ll}5.17 \text { Radijs } & 94\end{array}$

5.18 Groene Savooiekool $\quad 97$

$\begin{array}{ll}5.19 \text { Spinazie } & 100\end{array}$

5.20 Suikerbieten 103

5.21 Uien 106

$\begin{array}{lr}5.22 \text { Wortel } & 109\end{array}$ 
5.23 Sierteelt $\quad 112$

5.24 Amaryllis, Chrysant $\quad 115$

5.25 Bollentelers Noord-Holland $\quad 118$

5.26 Boomkwekerij $\quad 120$

5.27 Tulpen 123

5.28 Fruitbomen 126

5.29 Paprika, tomaat, komkommer, sla $\quad 129$

5.30 Komkommer $\quad 132$

$\begin{array}{ll}5.31 & \text { Paprika } \\ 5.32 & 135\end{array}$

5.32 Kropsla, IJsbergsla $\quad 138$

5.33 Sla 141

5.34 Tomaten 144

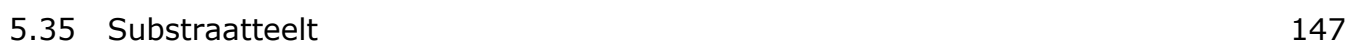




\section{Woord vooraf}

Het klimaat verandert en het watersysteem staat onder druk van conflicterende belangen. Een belangrijk aandachtspunt is de beschikbaarheid van voldoende zoet water en de toenemende verzilting in laag Nederland. In het regionale waterbeheer wordt de vraag naar water met een zo laag mogelijk zoutgehalte ingegeven door de vrees dat brak beregeningswater onder andere schade veroorzaakt in de landbouw. Er zijn echter steeds meer aanwijzingen dat diverse beregende vollegrondsteelten beter tegen hogere zoutgehalten bestand zijn, in ieder geval in bepaalde perioden, dan de aangenomen zouttoleranties suggereren. Ook zijn er aanwijzingen dat het beter is zoutschade te accepteren en zo droogteschade te voorkomen. De bestaande zoetwatervoorziening van Nederlandse verziltingsgevoelige gebieden is structureel aan de veilige kant, regiogebonden en qua 'normstelling' niet eenduidig. Dat is verklaarbaar. Waterbeheerders proberen onder alle omstandigheden onder de 'afgesproken' zoutdrempels te blijven en de gebruikers zijn tevreden met de geboden voorziening. Incidentele overschrijdingen van het zoutgehalte worden geaccepteerd. De vraag is echter: is dit beleid bij toekomstige, toenemende zoetwaterschaarste vol te houden? En is het wel nodig? Want: in hoeverre is verzilting van beregeningswater voor teelten in de vollegrond een probleem? De intensieve land- en tuinbouw wordt vaak beregend. De geschiktheid van beregeningswater kan worden beoordeeld op grond van de resultaten van een chemische analyse. De chemische samenstelling van grond- en oppervlaktewater varieert sterk; de herkomst van dit water is vaak al een goede indicator voor de geschiktheid voor beregening. Als water van mindere kwaliteit wordt gebruikt, kan dit heel wat problemen opleveren. Irrigatiesystemen kunnen verstopt raken door een te hoog ijzergehalte en zout $(\mathrm{NaCl})$ kan zich in de wortelzone ophopen waardoor de wateropname door wortels vermindert en wortels en bovengrondse delen beschadigd kunnen raken. Naast het optreden van schade aan gewassen kan ook de bodemstructuur verslechteren. Een te hoog zoutgehalte kan bij beregening leiden tot bladverbranding en verkleuringen, met als gevolg financiële schade voor de teler. Waterbeheerders in verziltingsgevoelige regio's zijn alert, en nemen maatregelen om verzilting van polderwateren zo goed mogelijk tegen te gaan.

Over de zouttolerantie van landbouwgewassen is de afgelopen decennia al heel veel opgeschreven. Zó veel zelfs, dat er sterke behoefte was aan een overzicht van de bestaande kennis. In deze rapportage is een poging gedaan een allesomvattend overzicht samen te stellen. Hierbij is uitsluitend gebruik gemaakt van bestaand materiaal.

Dit rapport is tot stand gekomen in goede samenspraak met de direct belanghebbenden en de opdrachtgever.

Wageningen, 13 oktober 2016

L C P M Stuyt, projectleider. 


\section{Samenvatting}

\section{Inventarisatie}

In een bureaustudie zijn ruim 100 geschriften onderzocht met als doel het maken van een overzicht van in Nederland gerapporteerde kennis van, en informatie over de zouttolerantie van beregende landbouwgewassen. De geraadpleegde bronnen omvatten een breed scala aan gewassen, omstandigheden etc., en zijn zeer divers. Het betreft wetenschappelijke artikelen in gerenommeerde tijdschriften en vakbladen, wetenschappelijke rapporten, jaarverslagen en Nota's van het ICW (het voormalig Instituut voor Cultuurtechniek en Waterhuishouding), memo's en 'lijstjes' die bij de doelgroep (telers en agrariërs in verziltingsgevoelige regio's) circuleren (of dit hebben gedaan), door bedrijven gedistribueerde informatiebladen en overig (ongepubliceerd) materiaal.

De zouttolerantie van gewassen (d.w.z. de tolerantie voor $\mathrm{NaCl}$, keukenzout) is een onmisbaar gegeven voor waterbeheerders die zoetwater aanvoeren dat geschikt moet zijn om gebruikt te worden voor beregeningsdoeleinden. Daarom is ervoor gekozen de studie te concentreren op de zogenoemde zouttolerantiedrempels van beregeningswater. Een zouttolerantiedrempel is het maximale zoutgehalte van beregeningswater waarbij nog geen sprake is van gewasschade. Gewasschade wordt echter door meer factoren bepaald dan alleen het zoutgehalte van beregeningswater. 'De' zouttolerantie van een gewas, vervat in één enkel getal, bestaat niet, maar is gerelateerd aan de omgevingsfactoren waaronder deze drempel is bepaald, en gewaskenmerken.

De verzamelde informatie is ondergebracht in een database (Excel), waarin ook eenvoudige statistische analyses zijn gedaan. Uit de enorme hoeveelheid informatie konden uiteindelijk 35 gewassen en gewasgroepen worden onderscheiden. Voor elk van deze groepen is opgetekend welke zouttolerantiedrempels zijn gerapporteerd en, voor zover mogelijk, onder welke omstandigheden dit is gedaan.

Twee dingen werden al snel duidelijk.

1. De onderzoekers beschrijven slechts bij hoge uitzondering gedetailleerd de randvoorwaarden en omstandigheden waaronder zij hun resultaten hebben geboekt.

2. De gerapporteerde zouttolerantiedrempels van een gewas of gewasgroep vormen in veel gevallen een vrij consistent beeld, maar vertonen wel een grote marge. Die marge werd echter vrijwel nooit toegeschreven aan specifieke omgevingsfactoren of gewaskenmerken. De enige uitzondering hierop vormde de resultaten van computersimulaties. De waarde hiervan is echter beperkt omdat zij niet altijd in detail zijn gevalideerd aan de hand van veldexperimenten.

\section{Analyse}

Gegeven de bevindingen is geconcludeerd dat het niet voor de hand ligt om de zouttolerantie van gewassen, uitgedrukt in het chloridegehalte van beregeningswater, vast te leggen in één representatieve drempelwaarde. In plaats daarvan worden daarom zouttolerantietrajecten voorgesteld. Dit zijn eenduidig gedefinieerde bandbreedtes waarbinnen de zouttolerantie van een gewas(groep) zich, gegeven de omstandigheden, met een zekere waarschijnlijkheid bevindt. Voor elk van de 35 gewassen en gewasgroepen is zo'n bandbreedte berekend rond de verwachtingswaarde van de normale kansverdeling die werd vastgesteld op grond van alle gerapporteerde drempelwaarden van de betreffende gewas(groep).

De in veelsoortige documenten gerapporteerde zouttolerantiedrempels vertonen, als groep van 35, qua waardenbereik weliswaar een aanzienlijke spreiding, maar de meeste drempels hebben een beperkte bandbreedte in de orde van grootte van $500 \mathrm{mg} \mathrm{Cl}^{-} / /$of minder. Daardoor kan het voorzieningenniveau met betrekking tot 'zout' in beregeningswater voor landbouwgewassen vrij nauwkeurig worden gespecificeerd, en wordt het bereiken van consensus hierover vergemakkelijkt. 
Uit de resultaten van het hier verzamelde materiaal kan niet worden geconcludeerd dat het beregeningswater wellicht (incidenteel) zouter kan. Deze vraag wordt met enige regelmaat gesteld als telers/agrariërs onder droge omstandigheden moeten beslissen of zij moeten beregenen met water met een verhoogde zoutconcentratie om droogteschade te voorkomen, of niet. Deze afweging kan op basis van deze bureaustudie niet worden gemaakt, want vergt meer onderzoek naar de kwantitatieve relaties tussen zouttolerantiedrempels enerzijds en omgevingsfactoren en gewaskenmerken anderzijds.

Overigens is uit eerdere studies op basis van resultaten van modelberekeningen wel geconcludeerd dat hogere chlorideconcentraties in beregeningswater acceptabel kunnen zijn in de afweging tussen zoutschade en het voorkomen van droogteschade (Stuyt et al., 2011).

\section{Leeswijzer}

De opbouw van dit rapport is als volgt. Na de Inleiding (Hoofdstuk 1) wordt in Hoofdstuk 2 een chronologische beschrijving gegeven van het onderzoek naar zoutschade aan landbouwgewassen in Nederland, inclusief een beknopte beschrijving van de onderliggende inhoudelijke concepten. In Hoofdstuk 3 wordt de gevolgde werkwijze van deze bureaustudie beschreven, gevolgd door de resultaten. De betekenis van deze resultaten wordt besproken in Hoofdstuk 4, waarna conclusies worden getrokken. Hoofdstuk 5 bevat gedetailleerde informatie, afzonderlijk gepresenteerd voor elk van de 35 geïdentificeerde gewassen en gewasgroepen. 


\section{$1 \quad$ Inleiding}

\subsection{Achtergrond}

Het klimaat verandert. De leveringszekerheid van zoet water en de toenemende verzilting in laag Nederland staan op de agenda. In onze kustregio's speelt het zoutgehalte van aangevoerd water dat volgens betrokkenen nog acceptabel is, in het operationele waterbeheer een grote rol. Rijkswaterstaat stuurt op zoutgehalte door waterstromen op innamepunten te reguleren en zoutlekken door (schut)sluizen te minimaliseren. Sommige waterschappen sturen op zoutgehalte, conform afgesproken doelstellingen voor landbouw en natuur. Voor drinkwater zijn wettelijke normen afgesproken. In de industrie spelen kostenoverwegingen bij het opwerken van oppervlaktewater tot proceswater en schade (i.c. corrosie) aan installaties een rol. In de landbouw wordt de vraag naar water met een zo laag mogelijk zoutgehalte ingegeven door de vrees dat beregeningswater met een verhoogd zoutgehalte altijd schade veroorzaakt. Bij natuur spelen vergelijkbare overwegingen.

Al een aantal jaren klinken er signalen dat oppervlaktewater dat - in de vorm van gietwater, beregening via sprinklers, door middel van druppelirrigatie en dergelijke - wordt gebruikt voor de voorziening van grondgebonden landbouwgewassen wel wat zouter kan. Een belangrijke signaalbron is het Zilt Proefbedrijf op Texel. Met deze signalen wordt echter weinig tot niets gedaan, waardoor onzekerheid blijft bestaan. De aandacht voor beregeningswater ligt voor de hand omdat een verhoogd zoutgehalte door een gebruiker gemakkelijk kan worden geconstateerd en de waterbeheerder hierop kan worden aangesproken. Dit geldt niet voor zelf gewonnen grondwater, noch voor het zoutgehalte in de wortelzone. Daarnaast zijn drempelwaarden van 'zout' in oppervlaktewater bruikbaar als 'stuurknoppen' in het operationele zoetwaterbeheer. Veel gebruikers geven aan dat zoetwater (i.c. water zonder verhoogd zoutgehalte) een essentiële randvoorwaarde is voor hun bedrijfsvoering en dat deze behoefte, gegeven de lokale situatie op hun bedrijf, onder alle omstandigheden vanzelfsprekend is. Deze vaak genoemde causaliteit lijkt echter betrekkelijk. De zoetwaterbehoefte kan inderdaad gerelateerd zijn aan de onderliggende fysica op percelen (grondslag, regionale hydrologische randvoorwaarden en dergelijke), maar kan ook worden toegeschreven aan de plaatselijke waterbeschikbaarheid en/of aan minder grijpbare fenomenen als gewoonterecht, regionale cultuurverschillen en zaken als de relatieve vertegenwoordiging van agrariërs in een waterschapsbestuur. Daarnaast blijken telers/agrariërs bij zoetwaterschaarste incidenteel, noodgedwongen, met brak water te beregenen om droogteschade te voorkomen. In zulke gevallen is lang niet altijd sprake van waarneembare zoutschade.

\subsection{Probleem- en doelstelling}

In het Deltaprogramma Zoetwater is het lastig gebleken economische analyses te maken voor de programmering van maatregelen en/of de beleidsmatige afweging van het voorzieningenniveau. Eén van de knelpunten is het gemis aan inzicht in de droogte- en zoutschade in landbouw en natuur. We hebben de zoutschade aan gewassen, ondanks recente inspanningen, in termen van percentage productieverlies of vermindering van de kwaliteit van het product, nog niet goed in beeld. Voor diverse lopende onderzoekstrajecten en de programmering van de tweede fase Deltaprogramma is een beter inzicht in de economische effecten van 'zout' in beregeningswater voor landbouwgewassen echter cruciaal. Telers/agrariërs moeten geregeld besluiten of het verstandig is om onder droge omstandigheden te beregenen met water met een verhoogd zoutgehalte. Deze afweging is ingewikkeld (zie Figuur 1) en kan op basis van deze bureaustudie niet worden gemaakt, want vergt meer onderzoek naar de kwantitatieve relaties tussen zouttolerantiedrempels enerzijds en omgevingsfactoren en gewaskenmerken anderzijds. 


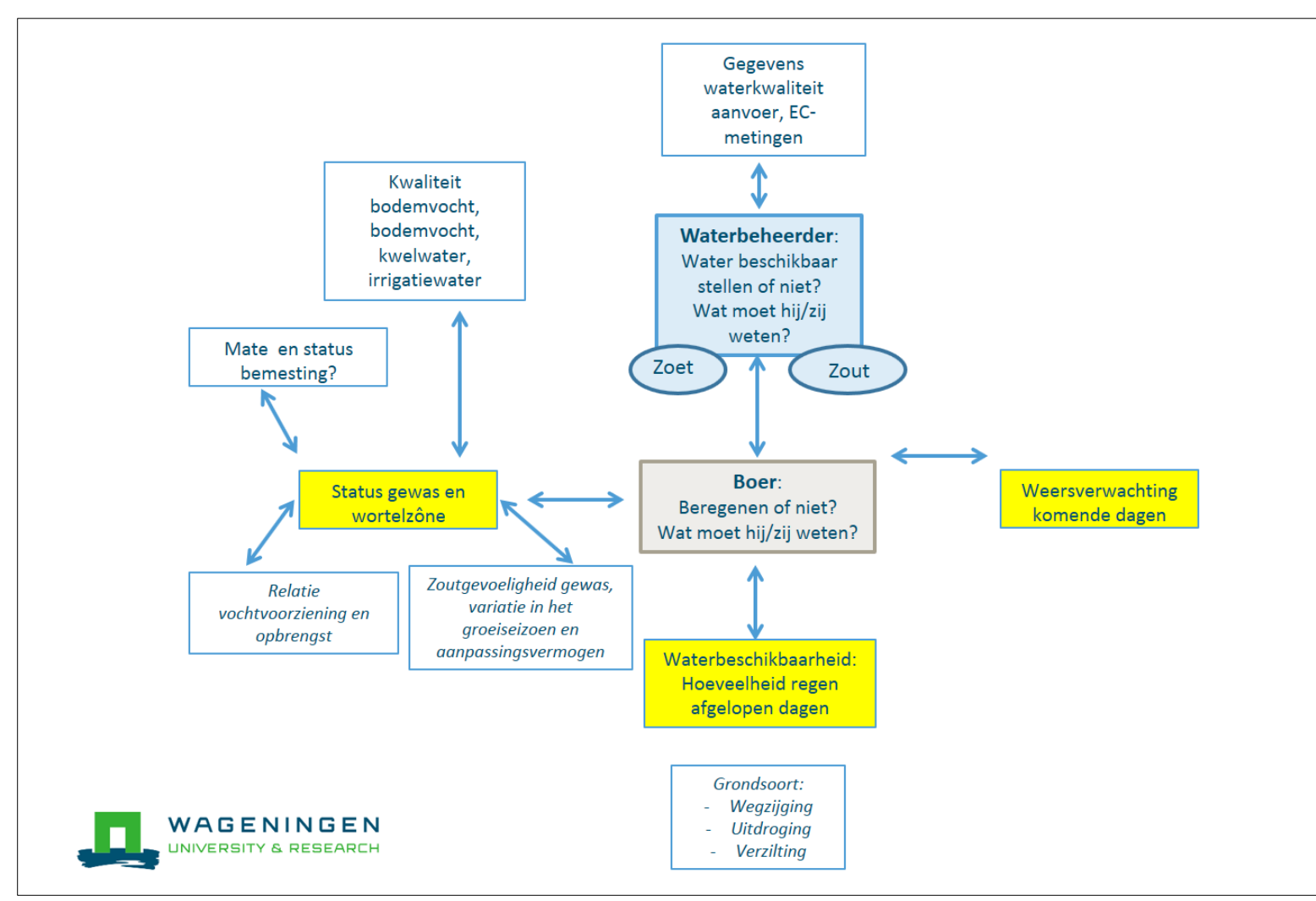

Figuur 1 Factoren die een rol spelen bij de afweging van een teler / agrariër om al dan niet te gaan beregenen.

Een aantal partners (STOWA, I\&M/WVL, EZ, VEWIN en provincies) werkt samen in project 'Waterwijzer'. Het traject is nu nog in een conceptuele fase waarbij een hydrologisch model (SWAP) aan een gewasgroeimodel (WOFOST) wordt gekoppeld. Dat moet uiteindelijk voor diverse gewassen worden uitgewerkt en geverifieerd aan de hand van praktijkgegevens. Begin 2017 worden de resultaten voor droogteschade van de belangrijkste gewassen verwacht. Voor een kwantitatieve bepaling van zoutschade aan landbouwgewassen is echter een langer traject voorzien.

De kennisvraag in deze studie omvat het ontsluiten van alle bestaande, relevante kennis van de meest recente gegevens die nog niet in beeld zijn tot historische, empirische gegevens die tot nu toe onopgemerkt zijn gebleven. De verkregen informatie is in deze rapportage beschikbaar gemaakt voor trajecten als Waterwijzer Landbouw, economische metamodellen als €ureyeopener, etc.

Eén belangrijke bron is een nog niet goed verkend empirisch spoor, te weten: de resultaten van de in de jaren 60 - 70 van de vorige eeuw uitgevoerde veldproeven, gerapporteerd door J.T.M. Huinink, destijds werkzaam bij CAD voor Bodem-, Water- en Bemestingszaken in de Akkerbouw en Tuinbouw te Wageningen. Deze bron is in deze studie meegenomen.

Het uiteindelijk doel van het onderliggende project is om in het waterbeheer in verziltingsgevoelige regio's effectiever te kunnen sturen op 'zout'. Deze studie geeft een aanzet in deze richting. Er is op korte termijn grote behoefte aan verbeterd inzicht in de urgenties bij beheersmaatregelen voor zoetwater in een brakke omgeving. In de eerste fase van het Deltaprogramma kon nooit goed worden vastgesteld: 'Doen we het goed? Is het gerechtvaardigd, op grond van kosten-baten?

\footnotetext{
1 www.waterwijzer.nl
} 


\subsection{Werkwijze en beoogd resultaat}

Voorgaande studies laten zien dat de kennis van zouttoleranties van landbouwgewassen versnipperd en niet eenduidig is, en dat de betrokkenen/deskundigen het niet altijd eens zijn. In dit project is de analyse van de zouttolerantie van landbouwgewassen (de methodologische kant, Fase 'A') onderwerp van analyse. De hierop volgende beleidskant, Fase ' $B$ ', die gestoeld is op methodologische informatie, wordt door deze onduidelijkheid sterk gehinderd. We zetten een 'knip' tussen methodologische kant ' $A$ ' en de beleidskant ' $B$ ', en doen in dit project een eerste aanzet om ' $A$ ' in te vullen, waarbij de aandacht uitsluitend gericht is op landbouwgewassen en de landbouwpraktijk. Dit wordt gerealiseerd door de bestaande empirische gegevens over zoutschade in landbouwgewassen te ontsluiten, waarna deze informatie in gezamenlijk overleg met alle betrokken partijen wordt geanalyseerd en gerapporteerd. De uitkomsten van deze studie kunnen gebruikt worden bij de ontwikkeling van een verbeterd instrumentarium binnen Waterwijzer landbouw en aan diverse andere instrumenten zoals metamodel €ureyeopener.

Bij dit project zijn de volgende randvoorwaarden benoemd.

1. Bij de betrokken wetenschappers (Zilt Proefbedrijf (Texel), De Bakelse Stroom, Deltares, WaterNexus (VU) en Wageningen University \& Research) en andere betrokkenen moet hetzelfde inzicht zijn over de betekenis en waarde van de informatie die dit project heeft opgeleverd.

2. Het materiaal dat bij elkaar wordt gebracht wordt op een zodanige manier gepresenteerd dat beleidsmakers en waterbeheerders de resultaten goed kunnen gebruiken bij het formuleren van nieuwe operationele beheersstrategieën.

3. Afstemming met Water Nexus (onderzoeksonderdeel 1.2 i-nurture) is gewenst en noodzakelijk. Punten van aandacht bij de afstemming zijn: 1) methodologisch - op welke gegevens wordt zouttolerantie gebaseerd; en 2) inhoudelijk - hoe worden gegevens verzameld. Op deze manier worden de onderzoeksactiviteiten vanuit Water Nexus en deze opdracht aanvullend aan elkaar.

4. De kennis en ervaring van het onderzoek dat in 2011 is uitgevoerd in opdracht van DGRW en LNV (EZ) (zie: Alterra rapporten 2200 en 2201) wordt in deze opdracht meegenomen.

5. Er wordt geen economische analyse uitgevoerd. Dit zal onderdeel zijn van het beleidstraject.

Wageningen University \& Research heeft deze opdracht uitgevoerd in nauwe samenwerking met een breed consortium van partijen: het Ministerie van EZ (Ir J Th M Huinink), 'Potato Meijer' (Ir G Heselmans), het Zilt Proefbedrijf Texel (Dr A de Vos) en Ir R J Oosterbaan (ex Alterra/ILRI).

De zouttolerantiedrempels zijn ondergebracht in een database, en voorzien van info over de omstandigheden waaronder de gerapporteerde experimenten/pilots zijn uitgevoerd. Gekeken is naar zaken als: met welke nauwkeurigheid er is gemeten; betreft het alleen computersimulaties, zonder verificatie in het veld? Naast afzonderlijke gewassen zijn ook gewasgroepen geïdentificeerd, conform de geanalyseerde rapportages.

Tijdens de looptijd van het project heeft het projectteam de (tussen-)resultaten van de analyse en interpretatie viermaal in zogenoemde Kennistafels besproken met de begeleidingsgroep ${ }^{2}$, bestaande uit Drs R J M Teunissen (Min I\&M-DGRW), Ir N Kielen (RWS-WVL), Drs D Kern (Unie van Waterschappen), Ir J Th M Huinink (Ministerie van EZ)) en Ir R Ruijtenberg (STOWA). Voor de inhoudelijke discussies was het gezelschap aangevuld met Ir G Heselmans (Meijer Potato, Rilland)', Dr A de Vos (Zilt Proefbedrijf Texel), Ir R J Oosterbaan (ex Alterra/ILRI) en Ir D Kea (LTO Noord). In de Kennistafels, gehouden op 4 maart, 22 april, 23 juni en 14 september 2016, is afstemming van dit project met gerelateerde programma's, projecten en applicaties als Waterwijzer Landbouw, Water NEXUS en $€$ ureyeopener aan de orde geweest.

\footnotetext{
2 Op 19 maart 2015 werd een eerste 'Kennistafel Zout' gehouden, georganiseerd door Rijkswaterstaat en STOWA, met deelname van een grote diversiteit aan stakeholders. De ervaringen uit die kennistafel zijn in dit project gebruikt en is voor het inwinnen van informatie en adequate afstemming met andere ontwikkelingen gestreefd naar het formeren van een meer wetenschappelijk georiënteerd team.
} 


\section{Inventarisatie zoutschade aan landbouwgewassen in Nederland}

\section{$2.1 \quad$ Inleiding}

In de dagelijkse praktijk wordt gestreefd naar een minimaal zoutgehalte van beregeningswater, maar het is de vraag in hoeverre minder zoutgevoelige grondgebonden gewassen in de praktijk schade ondervinden wanneer zoutgehalten (incidenteel) enigszins zouden oplopen. Daar werden 50 jaar geleden al vraagtekens bij gezet. Het Wageningse Instituut voor Cultuurtechniek en Waterhuishouding (ICW) deed vanaf de oprichting in 1956 jarenlang onderzoek naar de zouttolerantie van tuinbouwgewassen. Aandacht voor de zouttolerantie van gewassen in open vollegrondsteelten werd niet nodig geacht, omdat er geen problemen werden gerapporteerd. In een rapportage ter gelegenheid van het tienjarig bestaan geeft het ICW (1967) daarvoor de volgende verklaring: 'Het neerslagoverschot tijdens de winterperiode $(200 \mathrm{~mm})$ is voldoende om de zouten die tijdens het voorbije groeiseizoen zijn opeengehoopt, uit te spoelen. De meeste landbouwgewassen en sommige tuinbouwgewassen die in de vollegrond worden geteeld, zullen niet te maken krijgen met gevaarlijke verziltingsproblemen omdat de zouttolerantie hoog is en de toename van het zoutgehalte van het bodemvocht bij veldcapaciteit laag'. Met andere woorden: het wordt in de wortelzone zelden of nooit 'te zout', en àls dat al gebeurt is het van korte duur, omdat er wel weer een bui overheen komt. Dit argument heeft ondertussen weliswaar in kracht gewonnen omdat de jaarlijkse hoeveelheid neerslag in ons land sindsdien trendmatig en significant is gestegen, maar dat geldt ook voor de kans op langere, aaneengesloten perioden van droogte.

Aan de orde is de zoutgevoeligheid van grondgebonden, beregende gewassen. De waaier aan percepties van het operationele zoetwaterbeheer staat de ontwikkeling naar het zoeken van mogelijkheden voor gebruik van beregeningswater met een verhoogd zoutgehalte in de landbouw in de weg. Daarom past het dit gegeven en de effecten hiervan (duurzaamheid, geld) kritisch tegen het licht te houden. De onduidelijkheid rond de schadelijke effecten van 'zout' op landbouwgewassen wordt vertaald in 'conservatieve/veilige aannames' over zouttoleranties. Er zijn echter steeds meer aanwijzingen dat sommige gewassen aanzienlijk beter tegen hogere zoutgehalten bestand zijn dan de anno 2016 veronderstelde zouttoleranties suggereren.

Mocht dit zo blijken te zijn dan zou dit goed nieuws zijn voor alle partijen die te maken hebben met 'zout'. Voor Rijkswaterstaat en de waterschappen betekent dit dat er meer flexibiliteit in het waterbeheer ontstaat, met name in droge perioden. En boeren kunnen veel droogteschade voorkomen.

Dit perspectief is aanleiding om de bestaande kennis - zowel wetenschappelijke als ervaringskennis tegen het licht te houden, te analyseren en te verkennen wat dit betekent voor de zouttolerantienormen van landbouwgewassen en het zoetwaterbeheer.

De in Nederland gehanteerde zouttoleranties van grondgebonden, beregende landbouwgewassen passeren de revue, in historisch perspectief. Daarna geven we een korte beschrijving van de huidige wetenschappelijke stand van zaken ten aanzien van de effecten van verzilting op bodem en gewasgroei. 


\subsection{Effect van zout in de bodem op gewasgroei en - opbrengst}

Zout $(\mathrm{NaCl})$ dat zich ophoopt in de wortelzone kan op verschillende manieren schade aan planten veroorzaken (zie Figuur 2):

1. Reductie van de wateropname door wortels. Zouten die zijn opgelost in het water in de wortelzone maken de osmotische potentiaal van de bodem meer negatief, waardoor de plant er 'harder aan moet trekken' en waardoor de huidmondjes eerder sluiten, met verdampings- en opbrengstreductie tot gevolg. Dit effect is vergelijkbaar met dat bij droogte.

2. Toxische werking. Zodra natrium in de bladeren van de plant komt kan het de fotosynthese en enzymactiviteiten in het cytoplasma remmen, waardoor de groeisnelheid afneemt. Daarnaast kan het de opname van kalium remmen, en daarmee de ionenbalans in de plant verstoren.

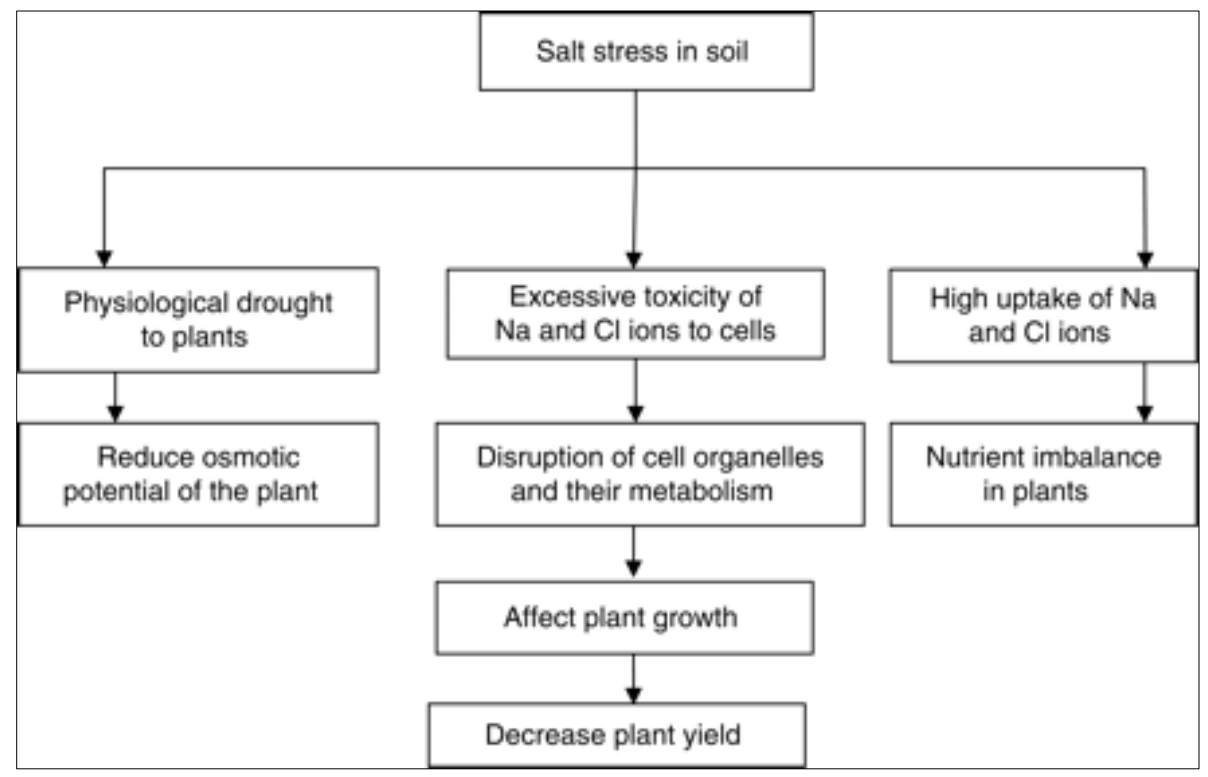

Figuur 2 Oorzaken van schade aan planten ten gevolge van zoutstress in de wortelzone.

Planten hebben echter in de loop van de evolutie drie verschillende mechanismen ontwikkeld om de negatieve effecten van zout tegen te gaan (Munns en Tester, 2008):

1. Natriumuitsluiting aan het worteloppervlak om te voorkomen dat het $\mathrm{Na}^{+}$-gehalte in de bladeren oploopt tot toxische concentraties. Natrium kan direct door de wortels worden tegengehouden door plantensoorten die tot de groep van de zogenaamde 'excluders' behoren.

2. Opslag van natrium en chloride in de vacuole van cellen in allerlei organen van de plant om een toxisch niveau in het cytoplasma van de bladcellen te voorkomen. Dit is het meest voorkomende mechanisme en komt bij verschillende plantensoorten (in meer of mindere mate) voor, zoals in gerst (Munns et al., 2006), kool (Shirazi et al., 2011), paprika (Blom-Zandstra, 2000), en soja en komkommer (Dabuxilatu and Ikeda, 2005).

3. Aanpassing van de osmotische waarde, zoals bijvoorbeeld voorkomt bij bonen (Ashraf et al., 2013). Planten nemen dan actief extra ionen zoals Kalium op uit het bodemvocht en/of maken zelf organische metabolieten aan en passen daarmee hun osmotische druk in het cytoplasma aan. Het aanmaken van organische metabolieten vergt een deel van de beschikbare energie van de plant, wat ten koste gaat van de groeisnelheid (Yeo, 1983).

De mate waarin planten over deze mechanismen of combinaties ervan beschikken en hun effectiviteit om zo min mogelijk schade te ondervinden variëren sterk tussen plantensoorten, zijn sterk ras afhankelijk en hangen samen met factoren als leeftijd van de plant tijdens blootstelling, duur van de blootstelling, zoutconcentratie, bodemkarakteristieken, klimatologische omstandigheden, etc. Mede hierom bestaat tussen landbouwgewassen een grote variatie in zouttolerantie (Shannon, 1997). 


\subsection{Chronologisch overzicht}

\section{Vóór 1940: Zout- en droogteschade herkend als probleem}

In vroege literatuur is al veel aandacht voor de reactie van bodems en landbouwgewassen op verzilting (Ponse, 1808; Mayer, 1877; Hissink, 1906, 1907a 1907b, Smeding, 1919-1920, 1921; Nobel, 1921). Raats (2014) geeft hiervan een voortreffelijk overzicht. Het meest relevante resultaat in deze vroege periode en belangrijke aanleiding voor het doen van vervolgonderzoek, was de introductie van 'zoutparameters' A, B en C door Nobel (1921) en Smeding (1921). De A-waarde is het vochtgehalte in 100 gram droge grond (gram), B de hoeveelheid zout in 100 gram droge grond ( gram) en C de zoutconcentratie per liter water (gram). Nobel en Smeding suggereerden in 1921 dat de gewasreactie op zout vooral wordt bepaald door parameter C.

In de herfst van 1921 rapporteert Van der Have, werkzaam bij het Landbouwkundig Proefstation te Groningen, problemen met een slechte groei van gewassen in de provincie Zeeland. De vermoedelijke oorzaak was een hoog zoutgehalte van de bodem, vooral in droge perioden. Hissink en Zijlstra (1922) concludeerden echter dat de oorzaak droogteschade was (Raats, 2014).

In de periode 1917-1939 was plantenfysioloog Zijlstra hoofd van de botanische afdeling van het Landbouwkundig proefstation te Groningen. Zijn publicatie uit 1922 was gewijd aan de problemen van droogte en verzilting. In de periode 1929-1933 bestudeert hij de kieming en groei van een groot aantal gewassen, op substraat, met sterk uiteenlopende zoutgehalten (zie kader).

De kiemexperimenten waren uitgevoerd met zes zoutoplossingen: de 'Van der Crone cultuur-oplossing' (1000 mg KNO $3,500 \mathrm{mg} \mathrm{MgSO} 4,250 \mathrm{mg} \mathrm{Fe}\left(\mathrm{PO}_{4}\right)_{2}$, $500 \mathrm{mg} \mathrm{CaSO}$, en $250 \mathrm{mg} \mathrm{Ca}\left(\mathrm{PO}_{4}\right)_{2}$ per liter), de 'Van der Crone cultuuroplossing plus kunstmatig zeewater' $(25830 \mathrm{mg} \mathrm{NaCl}, 3100 \mathrm{mg} \mathrm{MgCl}, 2110 \mathrm{mg} \mathrm{MgSO}$, $1270 \mathrm{mg} \mathrm{CaSO}_{4}$ per liter) en vier oplossingen bestaande uit de Van der Crone cultuur-oplossingen en verdunningen van kunstmatig zeewater, respectievelijk 15000, 10000, 5000 en $1000 \mathrm{mg} \mathrm{NaCl}$ per liter. Deze zes kweekoplossingen werden aangeduid als 0, 1, 5, 10, 15 en 25.8, met respectievelijk 2000 (Van der Crone), 3270, 8360, 14730, 21100 en 34870 (Van der Crone + zeewater) mg zout per liter. De lagere zoutconcentraties (2000, 3270 en $8360 \mathrm{mg} / \mathrm{l}$ ) bleken weinig invloed te hebben op het uiteindelijke kiempercentage, behalve bij aardbei en een bepaalde grasvariant. Zomertarwe en Engels raaigras bleken het minst zoutgevoelig, met respectievelijk nog $60 \%$ en $33 \%$ kieming in zeewater.

Het doel van deze experimenten was om te bepalen hoe ver de ontzilting van een bodem gevorderd moet zijn om min of meer te verzekeren dat het zaaien van een specifiek gewas gerechtvaardigd was en de oogst niet zou mislukken.

\section{1939-1950: strategische overstromingen 'triggeren' onderzoek naar de zouttolerantie landbouwgewassen}

In de periode 1939-1953 zijn grote gebieden in het zuidwesten van Nederland met zout water overspoeld. Ten dele kwam dit door militaire inundaties gedurende de Tweede Wereldoorlog en ten dele door natuurlijke oorzaken (dijkvallen, stormvloed van 1 februari 1953). In deze gebieden is toentertijd veel onderzoek verricht naar zoutuitspoeling naar structuurbederf van de gronden. Concluderend kan worden gezegd dat het zout weliswaar na ongeveer 1 tot 4 jaar is uitgespoeld, maar dat structuurherstel in oudere, kalkloze kleigronden vervolgens meer dan 8 jaar in beslag kan nemen (Nieuwenhuizen et al., 2003).

In 1940 verhuist Zijlstra naar Wageningen, waar een deel van zijn gegevens tijdens een bombardement in 1944 verloren gaat. Hoewel hij zijn experimenten in eerste instantie had ontwikkeld om de risico's van 'zout' in de Wieringermeer en de toekomstige IJsselmeerpolders vast te stellen, hadden de strategische overstromingen in de Tweede Wereldoorlog de interesse in het onderwerp vergroot. Daarom werd besloten om de na het bombardement resterende gegevens alsnog te publiceren (Zijlstra, 1946). 
Riemens (1941) publiceerde de eerste concrete cijfers over oogstreducties als gevolg van zoutschade voor witte bonen, bruine bonen, erwten, blauwmaanzaad, uien en aardappelen. Hij constateert grote verschillen in zoutgevoeligheid tussen gewassen en rapporteert voor aardappelen een oogstreductie van $25 \%$ bij gemiddeld $2800 \mathrm{mg} \mathrm{Cl}^{-} / \mathrm{l}$, terwijl witte bonen al bij $500 \mathrm{mg} \mathrm{Cl}^{-} / \mathrm{l}$ een vergelijkbare oogstreductie vertoonden.

De overstromingen van voor- en tijdens de Tweede Wereldoorlog stimuleerden het doen van vervolgonderzoek naar de zouttolerantie van landbouwgewassen na de Tweede wereldoorlog. Rowaan (1951) inventariseert onderzoeksresultaten tot 1944, Abell (1954) geeft een overzicht van de periode 1944-1954. Van den Berg (1950) rapporteert veldexperimenten naar de toleranties van landbouwgewassen;

\section{1950-1960: Het eerste onderzoek aan groententeelt in de vollegrond door het ICW}

In 1951 introduceren Dorsman en Wattel veldexperimenten met tuinbouwgewassen. Van den Berg (1952) beschrijft in zijn proefschrift experimenten naar de invloed van geabsorbeerde zouten op de groei en de opbrengst van landbouwgewassen op zoute bodems. Het betreft waarnemingen aan kieming en groei van zes landbouwgewassen die werden beregend met water met diverse zoutgehalten, en aan de ionsamenstelling in de gewassen en de bodem. Hij constateert duidelijke verschillen in gevoeligheid voor zout tussen verschillende groeistadia, die voor elk gewas echter weer anders uitpakken. Tijdens de kieming nam de zouttolerantie af in de volgorde zomergerst < erwten < tuinbonen < zomertarwe < kidneybonen (Van den Berg, 1950a, 1950b), terwijl bij de eindopbrengsten de volgorde juist anders was: zomergerst < suikerbieten < haver < zomertarwe $<$ vlas < aardappelen < tuinbonen < erwten < kidneybonen. Om een indruk te krijgen van het effect van het zoutgehalte van de grond op de wortelontwikkeling werden erwten opgekweekt in potten. De wortelgroei verminderde sterk wanneer het zoutgehalte in de bodemlaag tussen 30 en $60 \mathrm{~cm}$ minstens $6100 \mathrm{mg}$ zout per liter water bedroeg, en stopte bijna volledig bij $12900 \mathrm{mg} / \mathrm{liter}$.

Van den Berg (1952) wijdde een kritische beschouwing aan de in die periode heersende overtuiging dat de osmotische druk in een verzilte bodem de belangrijkste oorzaak is van de groeireductie van landbouwgewassen. Hij verdiepte zich in de fysiologische oorzaken van gewasschade en maakte daarbij onderscheid tussen osmotische effecten, zoutophoping in de plant en ongunstige ionenbalansen; zie Tabel 1 en Figuur 3, en stelde vast dat de zouttolerantie van gewassen sterk gerelateerd is aan de potentie van een gewas om de accumulatie van zout te beperken. 
Tabel 1 De mate van belangrijkheid van enkele fysiologische gevolgen van zoute substraten voor de groeivermindering van verschillende gewassen. Bron: van der Berg (1952).

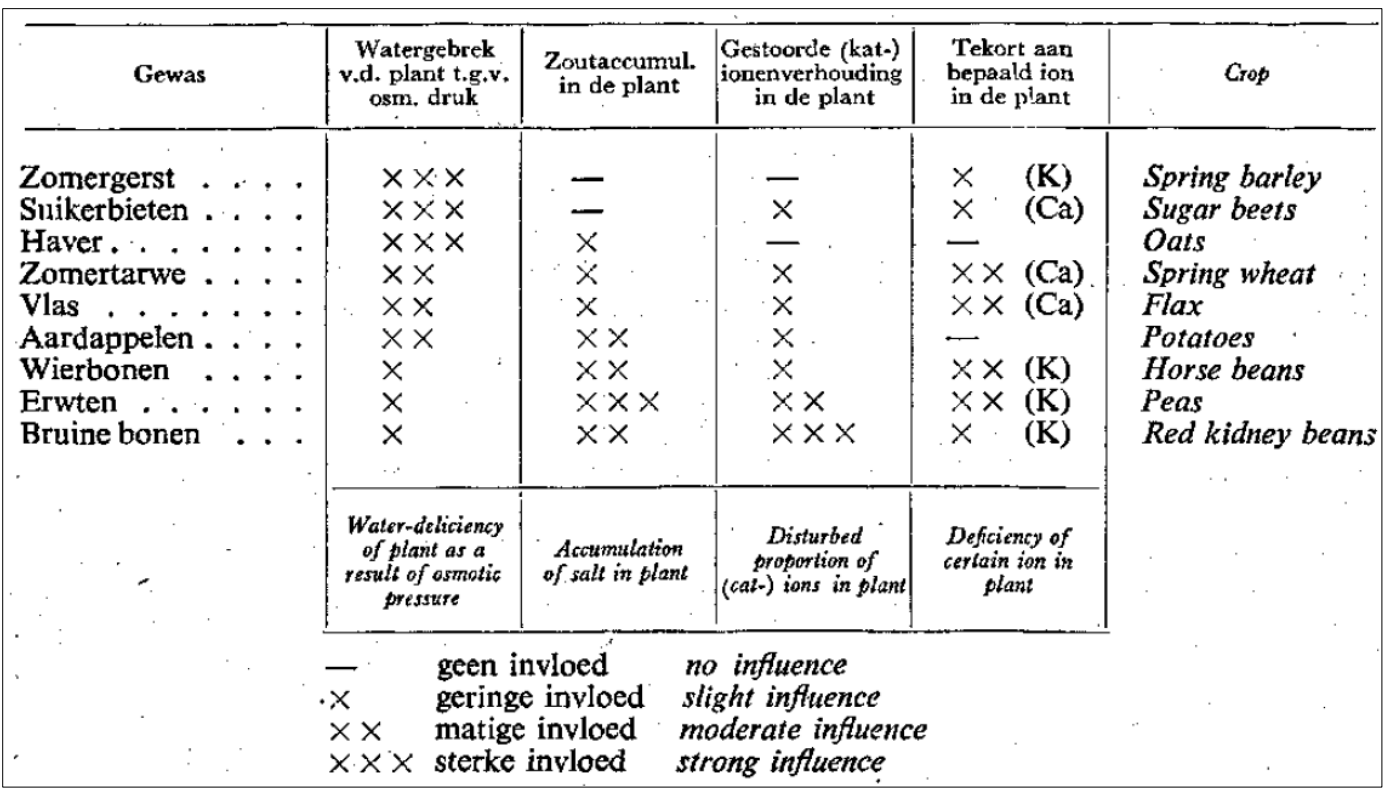

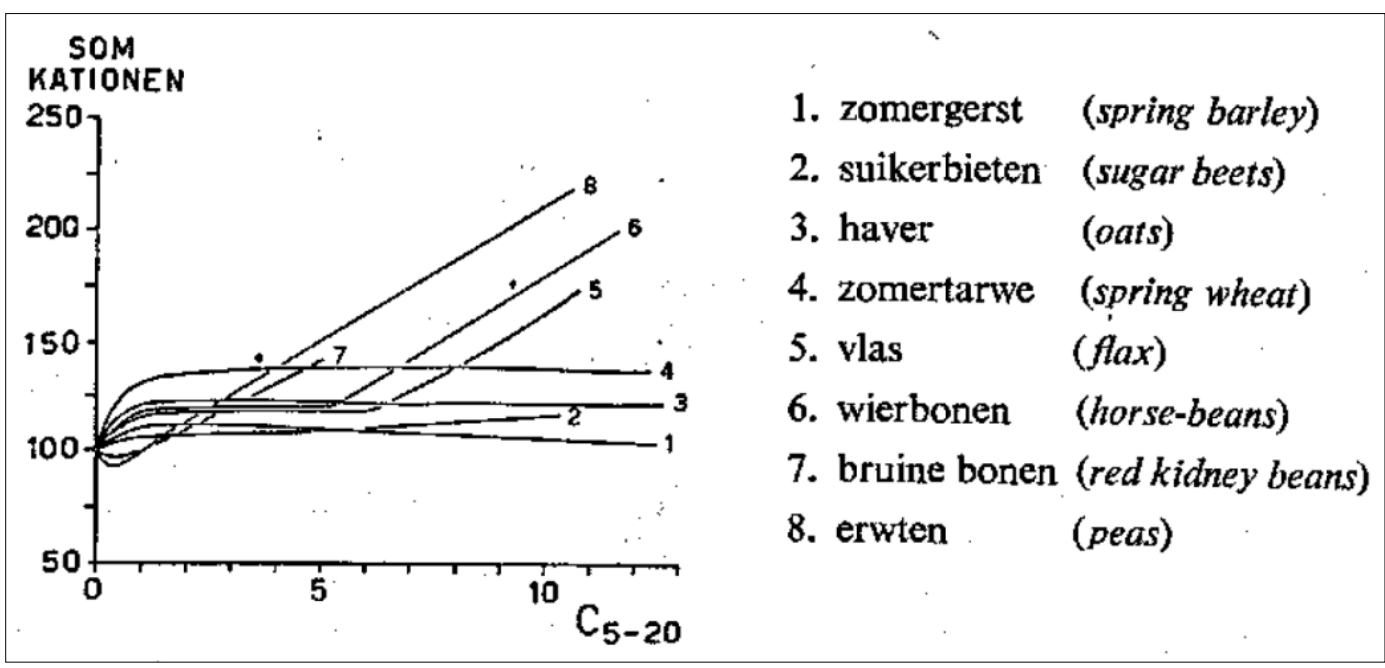

Figuur 3 Relatieve kationen-som, opgenomen door verschillende gewassen. Bron: Van den Berg (1952).

Dam (1953) doet voor het eerst onderzoek naar de zoutgevoeligheid van de belangrijkste vollegronds groentegewassen. Hij wordt later uitgebreid geciteerd door Hellings (1971) die een uitgebreide tabel van hem overneemt. De analyses zijn gericht op bodemwater.

\section{1960-1970: Start van onderzoek aan tuinbouw (onder glas) en aardappel en het leggen van relaties met de omgeving}

Het ICW intensiveert het onderzoek en neemt ook omgevingsfactoren in beschouwing. In het jaarverslag van 1962 beschrijft Van der Valk veldproeven met zout irrigatiewater aan sla, bonen en bloemkool. Hij rapporteert dat doseringen tot $2500 \mathrm{mg} \mathrm{Cl}$ per liter in het beregeningswater in het natte jaar 1962 geen nadelige invloed heeft op de opbrengst, maar dat er bij de hoge dosering wel ernstig structuurverval van de grond is opgetreden. In het ICW Jaarverslag van 1966 wordt onderzoek van Bierhuizen \& Ploegman beschreven, waaraan Van den Berg in 1967 opnieuw verwijst. Hierin wordt beschreven dat komkommers zeer gevoelig zijn en groeireductie vertonen bij $50 \mathrm{mg} / \mathrm{l}$, terwijl tomaten op kleigrond minder gevoelig ( $250 \mathrm{mg} / \mathrm{l}$ ) blijken dan op zandgrond (100 mg/l). In het jaarverslag van 
1968 wordt gemeld dat de hoeveelheid natuurlijke neerslag een rol speelt en dat ook voor komkommers onderscheid gemaakt kan worden tussen zand en klei. In 1968 rapporteert Baars dat de teelt van aardappelen in de zeekleigebieden vrij veel beregend wordt, en dat uit onderzoek is gebleken, dat bij een chloridegehalte van het sproeiwater van 500 en $1000 \mathrm{mg}$ per liter de schade niet groot is mits men het water in kleine giften toedient en de grond niet sterk laat uitdrogen.

\section{1970-1975: Opstellen van normen; start van onderzoek aan sierteelt}

Het ICW start in deze periode met bureaustudies waarin bestaande resultaten (ook uit de Verenigde Staten) worden geanalyseerd en samengebracht. Aan de hand van in de literatuur gevonden onderzoeksresultaten en de bij verschillende instellingen opgedane praktijkervaring wordt in 1970 geprobeerd normen op te stellen voor gietwater. Er wordt een indeling voorgesteld in vier zoutklassen: gevoelig, matig gevoelig, matig tolerant en tolerant. Couwenhoven (1971) publiceert normen voor sproeiwater, waarbij hij opbrengstreducties ontleend aan de eerder gepubliceerde onderzoeksresultaten van Zijlstra (1946) en Van den Berg (1950). Hellings (1971) beschrijft ook eisen inzake de kwaliteit van sproeiwater voor vollegronds groentegewassen. Zijn informatie over opbrengstreducties hebben betrekking op bodemwater en is ontleend aan van Dam (1953) en Bernstein (1964). Bernsteins gegevens komen uit de USA, waar dr. J. Wesseling van het ICW gedetacheerd was geweest. Wesseling introduceerde de Amerikaanse kennis in Nederland.

In het jaarverslag van het ICW van 1971 meldt Ploegman dat bloemen (en met name bollen) heel gevoelig zijn (ICW, 1971). Bij de cultivar 'Apeldoorn' treedt al duidelijk waarneembare bloeischade op als het chloridegehalte van beregeningswater tijdens de bloei boven de $300 \mathrm{mg}$ per liter komt. De grenswaarde waarbij het aantal bloemen niet afneemt ligt bij ongeveer $80 \mathrm{mg} \mathrm{Cl} / /$, wanneer het bodemwater 'op veldcapaciteit' is. Toch blijkt het niet mogelijk om één duidelijke drempelwaarde per bloemtype te formuleren en gedurende een lange periode hierna grote onduidelijkheid blijft bestaan over de gewenste kwaliteit van het gietwater.

\section{1975-1980: Meer bureaustudies; start onderzoek zouttolerantie tulpen}

In de tweede helft van de jaren 70 van de vorige eeuw komt het ICW met nieuwe bureaustudies waarin opnieuw bestaande resultaten worden geanalyseerd en samengebracht (Rijtema,1975; Ploegman, 1975, 1978). In ICW Nota 856 geeft Rijtema (1975) een overzicht van resultaten van Ploegman, Bierhuizen, Sonneveld en van den Ende (1967-1971), maar de getallen worden niet gekoppeld aan gewassen, of alleen aan gewasgroepen. In deze periode wordt ook voor het eerst onderzoek verricht naar schadedrempels voor de 'bolopbrengst bij tulpen', gemeten aan bodemvocht, en komt de FAO voor het eerst met een publicatie over effecten van zout op landbouwgewassen (FAO, 1976). Het jaar 1976 verloopt in ons land extreem droog, gaat als historisch droog jaar de boeken in en zal in toekomstige studies als referentiejaar worden gebruikt.

\section{1980-1990: PAWN na het historisch droge jaar 1976; bestaande informatie nogmaals gebundeld, maar de bronvermelding is onvolledig of afwezig}

In 1982 worden in het kader van de PAWN-studie (PAWN=Policy Analysis of Water Management for the Netherlands) zouttolerantiefuncties geformuleerd (Abrahamse, et al., 1982) en door RIZA gebruikt in model DISTAG (=District Hydrologic and Agriculture Model). Aanleiding voor deze studie was de uitzonderlijk droge zomer van 1976, waardoor de droogteproblematiek (weer) op de landelijke beleidsagenda kwam (Boogerd, 2005). In 1983 bundelt Jansen in een Nota van het ICW alle informatie die tot dan toe bekend is (Jansen, 1983). Er worden grenswaarden gegeven voor het maximaal toelaatbare totale zoutgehalte en het chloridegehalte per liter irrigatiewater, in afhankelijkheid van de jaarlijkse watergift en de gevoeligheid van het gewas, maar een bronvermelding ontbreekt, en blijkt ook tijdens deze bureaustudie niet te achterhalen ( $P$. Jansen, persoonlijke mededeling). De FAO publiceert Itrrigation \& Drainage paper 29, waarin de op dat moment bestaande kennis rond verzilting is gebundeld; deze kennis is anno 2016 nog steeds actueel (Ayers \& Westcot6, 1985). 
Huinink (1987a) heeft zijn eigen visie op de wijze waarop het onderzoek moet worden geïnterpreteerd en publiceert een tabel met generieke 'attenderingswaarden voor waterkwaliteit': irrigatiewater. Hierin zijn de zes tolerantiedrempels gebruikt die eerder waren gerapporteerd (Jansen, 1983; Rijtema, 1983; Ploegman et al. 1967-1971), en verwerkt in lineaire grafische voorstellingen, waarin voor diverse gewasgroepen de 'opbrengstderving' tegen de EC van het bodemvocht wordt uitgezet.

In 1988 verschijnt het 'Cultuurtechnisch Vademecum'; hierin wordt de door Jansen (1983) verstrekte informatie een op een overgenomen; ook hier zonder bronvermelding. Dit feit is opmerkelijk, omdat het Vademecum een gezaghebbend standaardwerk/handboek was (en anno 2016 nog steeds is). In hetzelfde jaar fuseert het Instituut voor Cultuurtechniek en Waterhuishouding (het ICW) met de Stiboka (de Stichting voor Bodemkartering) tot 'Staring Centrum-DLO'.

\section{1990-2000: Twijfel aan zouttolerantie tulpen: het IKC neemt de rol van het in 1988 verdwenen ICW over}

In 1993 stelt het IKC-AT Afd. Bloembollen vast dat de kennis op grond waarvan in Nederland rond de kwaliteit van gietwater keuzes gemaakt worden berust op gedateerd onderzoek en dat vraagtekens kunnen worden gezet bij de onderbouwing van de gebruikte criteria. Ook zijn de afgeleide zouttoleranties soms niet eenduidig (Huinink, 1993). Een goed voorbeeld is tulpen: op basis van onderzoek van Ploegman staan ze 'in de boeken' als gevoelig (schadegrens $200 \mathrm{mg} / \mathrm{l}$ chloride) terwijl door IKC en de praktijk in de Flevopolders 600 mg (zandgrond) resp. 1500 mg/l (zavel- en lichte kleigrond) als schadegrens wordt genoemd.

In 1998 fuseert het Staring Centrum met Instituut 'De Dorschkamp' tot onderzoekinstituut Alterra, DLO-onderdeel van de Environmental Sciences Group (ESG) van Wageningen UR. In hetzelfde jaar zet Huinink (1998) alles nog eens op een rij. Hij onderschrijft de eerdere gegevens van Ploegman:

'Bloembollen zijn zeer zoutgevoelig. Bij chloridegehalten van het beregenings- c.q. infiltratiewater hoger dan $200 \mathrm{mg} \mathrm{cm}$ vindt reeds een duidelijke opbrengstdaling plaats'. Kort hierop volgt een zeer uitgebreide Amerikaanse (US Salinity Laboratory, Riverside, Californië) bureaustudie gepubliceerd door Shannon \& Grieve (1999), waarin enkele zouttolerantiedrempels staan, maar deze omvatten veel tuinbouwgewassen, weinig vollegrondgewassen, zijn vooral toegespitst op geïrrigeerde landbouw in (semi-) aride gebieden en daarmee voor de Nederlandse situatie minder relevant. In hetzelfde jaar verschijnt FAO's standaardwerk 'Soil Salinity assessment', waarin veel elementaire kennis en ervaringen (deels afkomstig van het US Salinity Laboratory) laagdrempelig zijn gebundeld (Rhoades et al., 1999).

In Bakel et al. (2009) is beschreven dat de zoutschadegevoeligheid van tulpen ter discussie staat. Decennia geleden stelde onderzoeker Ploegman (1972) al vast dat bolgewassen zoutgevoelig zijn. Hij legde de schadedrempel voor gladiool bij beregeningswater met een chloridegehalte van $100 \mathrm{mg} / \mathrm{l}$, en kwam daarmee in de buurt van resultaten van buitenlands onderzoek. Ploegman is de enige onderzoeker die ook aan andere bolgewassen zouttolerantieonderzoek heeft verricht: tulp (Ploegman, 1972), hyacint, narcis en krokus (Ploegman, 1977) en lelie (Ploegman en Boontjes, 1981). Volgens collega-onderzoeker Van der Valk (1970) zijn tulpen echter matig zoutgevoelig. Overigens is de vaststelling van schadedrempels op basis van de beschikbare gegevens soms arbitrair. Ploegman (1975) stelt deze bijvoorbeeld voor tulp op $130 \mathrm{mg} \mathrm{Cl}$ per liter bodemvocht vast, maar op basis van dezelfde gegevens zou ook rond 600 mg per I genomen kunnen worden (Dam et al., 2007).

\section{2000-2009: Introductie Maas-Hoffman schadefunctie en discussie over de interpretatie}

In 2000 ziet een hernieuwde uitgave van het Cultuurtechnisch Vademecum uit 1988 het licht. Hierin is Huininks' publicatie uit 1998 integraal opgenomen. De drempelwaarden die Huinink in zijn publicatie in 1987 rapporteerde worden 13 jaar na dato opnieuw gepubliceerd.

De zouttolerantie van een gewas kan beschreven worden door de gewasopbrengst te plotten als functie van het zoutgehalte van de bodem. Deze functie is meestal S-vormig. Maas en Hoffman (1977) 
stelden voor om deze continue opbrengstcurve te vervangen door twee lijnstukken: een horizontaal lijnstuk met maximale opbrengst, gevolgd door een lijn waarvan de helling de opbrengstreductie geeft bij stijging van het zoutgehalte; zie Figuur 4. In 2002 verschijnt een FAO-publicatie over het beheer van drainagewater in (semi-)aride gebieden (Tanji en Kielen, 2002). In een bijlage bij dit rapport zijn zouttolerantiecijfers (drempelwaarde, helling) van 81 gewassen opgenomen, maar deze zouttoleranties zijn gemeten onder omstandigheden die in ons land niet voorkomen. Zie ook Bakel en Stuyt (2011), Hoofdstuk 3. In 2003 publiceren Roest et al. de resultaten van een nieuwe bureaustudie waarin ze de Maas-Hoffman schadefunctie in Nederland introduceren, op basis van rapporten van Maas en Hoffman (1977), Landon (1984), Maas (1990), Allen et al. (1998) en Aendekerk (1999, 2000); zie Figuur 4.

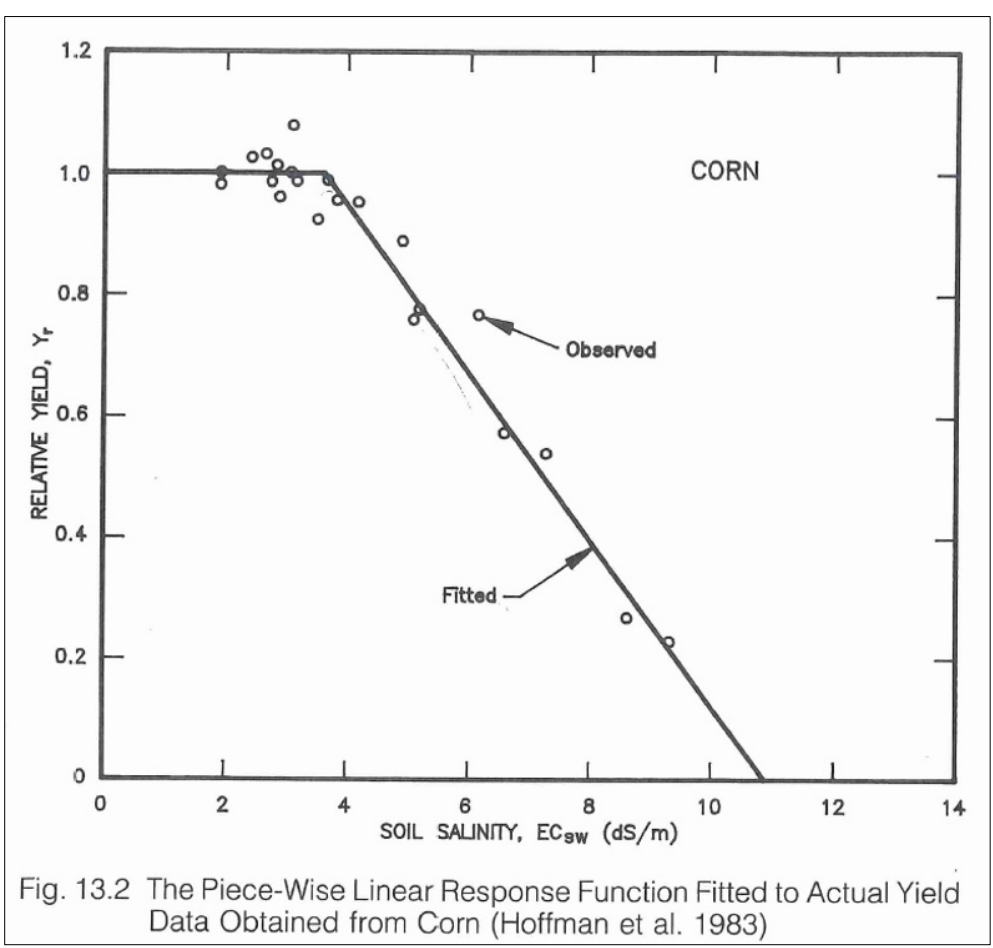

Figuur 4 Voorbeeld van een reductiefunctie van gewasopbrengst bij toenemend zoutgehalte van de bodem, met drempelwaarde en helling, gedefinieerd volgens de Amerikaanse onderzoekers Maas en Hoffman (1977). Boven een bepaalde drempelwaarde van het zoutgehalte van de bodem daalt de opbrengst recht evenredig met het zoutgehalte (constante helling). Dit concept is gedefinieerd op basis van veel lysimeteronderzoek, uitgevoerd door het US Soil Salinity Laboratory, Riverside (CA), USA.

Uit de literatuurreferenties maken Roest et al. op grond van hun expertkennis echter een keuze uit de 'meest waarschijnlijk juiste tolerantiegegevens' (zie kader). Roest et al. (2003) vergelijken hun resultaten met de PAWN-waarden uit 1982 en met waarden uit het Cultuurtechnisch Vademecum van 1988.

Toelichting op de werkwijze: 'De resultaten van de literatuurstudie hebben betrekking op de gewasgroepen die in Agricom worden gebruikt voor de droogte- en zoutstress. Per individueel gewas zijn de resultaten uit de verschillende bronnen vergeleken en is een keuze gemaakt voor de meest waarschijnlijk juiste waarde voor Nederlandse omstandigheden. Vervolgens zijn de grenswaarde en de hellingshoek van de afzonderlijke gewassen per gewasgroep gemiddeld. Ten slotte zijn de gegevens genormaliseerd tot de grenswaarde en hellingshoek behorende bij het vochtgehalte waar Agricom mee rekent. 
De normen van Roest et al. (2003) blijken strenger uit te vallen dan die uit het Cultuurtechnisch Vademecum; die voor gietwater voor bloembollen gaat met een factor zes (!) omlaag. Voor aardappelen, snijmaïs, sierteelt en vollegrondsgroente gaat de norm met een factor drie omlaag en voor fruitbomen met een factor twee. De norm voor glastuinbouw blijft min of meer gelijk. Voor gras gaat de norm met ongeveer de helft omhoog en voor granen en suikerbieten met een factor twee. Dit is waarschijnlijk te verklaren door het feit dat de onderzoekers voor teelten onder glas en bollen terugvallen op oud ICW-onderzoek, maar voor andere (grondgebonden) teelten voornamelijk gegevens gebruiken van Maas \& Hoffman en FAO. Voor de tuinbouwgewassen is vanuit kosten gerekend en het gewenste chloridegehalte van het gietwater gezet op $<50 \mathrm{mg} / \mathrm{l}$, omdat hogere concentraties verlies van dure meststoffen tot gevolg kan hebben.

In een overzicht van de Nederlandse literatuur (Sonneveld, 1988) blijkt echter dat voor gewassen onder glas in Nederland de tolerantie voor zout veel groter is dan in de aride gebieden (waarop de internationale literatuur voornamelijk betrekking heeft). De in Nederland verkregen gegevens van Ploegman wijken hiervan af maar zijn niet gebruikt.

In 2009 beginnen de onderzoekers met het model SWAP voor zand, klei en zavelgronden simulaties uit te voeren (Roest et al., 2009) om het vochtgehalte in de bodem beter in de vingers te krijgen en de vaste 'multipliers'/factoren tussen het zogenoemde bodemextract (de 'saturated paste') en het bodemzoutgehalte is als 'te rigide' te kunnen loslaten. De simulaties worden echter niet geverifieerd door veldmetingen. In een workshop met twee uitgenodigde, hoog aangeschreven buitenlandse onderzoekers (Zvi Plaut uit Israël en Jan Hopmans uit de Verenigde Staten) wordt het gebruik van de Maas-Hoffmann schadefunctie voor de Nederlandse situatie uitgebreid geëvalueerd. De buitenlandse onderzoekers zijn zeer kritisch, maar vinden voor hun kritiek bij de onderzoekers nauwelijks gehoor, waarmee de in Nederland gebruikte aanpak in stand blijft.

\section{2010-2015: De vraag 'kan het niet wat zouter?' komt op de agenda}

In opdracht van I\&M verschijnt in 2011 een nieuwe literatuurstudies (Van Bakel en Stuyt, 2011) waarin een 'update' wordt gegeven van de state of the Art. Over bollen blijkt (nog steeds) verrassend weinig bekend te zijn. Van Bakel en Stuyt hebben daarom in 2010 de bibliotheek van de Koninklijke Algemeene Vereeniging van Bloembollencultuur (KAVB) geraadpleegd. De conclusie was dat bol- en knolgewassen, gegeven dit kennishiaat, veiligheidshalve worden geclassificeerd als 'gevoelig', met een drempelwaarde $<300 \mathrm{mg} \mathrm{Cl} /$, conform Ploegman $(1975,1978)$. Voor tulpen wordt op grond van eerder onderzoek door Van der Valk (ICW, 1962), Ploegman en van der Valk (1972) en regionaal expertoordeel een uitzondering gemaakt: zij zijn als matig gevoelig geclassificeerd, omdat op de grove zandgronden (geestgronden) bij aanvullende vochtvoorziening via de subinfiltratie aan de chlorideconcentratie hogere eisen moeten worden gesteld. Bij drogend weer kan namelijk geen doorspoeling van de wortelzone door beregening worden gerealiseerd. Daarom wordt hierbij voor het oppervlaktewater de een grens aangehouden van $200 \mathrm{mg} / \mathrm{l}$.

Uit bovenstaand chronologisch overzicht kan worden geconcludeerd dat de in Nederland gebruikte zoutschadefuncties voor beregende teelten in de landbouw deels in de praktijk zijn ontstaan, deels zijn gebaseerd op buitenlands wetenschappelijk onderzoek (Stuyt et al., 2006) maar ook wordt ingegeven door 'veiligheidsoverwegingen' om de kans op zoutschade zo klein mogelijk te doen zijn. Het operationele zoetwaterbeheer tegen verzilting is regio gebonden, qua normstelling niet eenduidig en aan de veilige kant. Meer informatie is beschikbaar in Stuyt et al. (2013).

De chloridenormen zijn, conform afspraak, streng (Bakel en Stuyt, 2011; Stuyt, 2014³.). Beheerders proberen onder alle omstandigheden onder deze afgesproken zoutdrempels voor beregeningswater te blijven. Op lange termijn zal wellicht vaker en langduriger sprake zijn van zoetwaterschaarste. De strenge handhaving van de huidige normen kan daarom wellicht steeds moeilijker worden gehandhaafd. Misschien moet de leveringszekerheid worden vervangen door een zoetwaterregime met een risicobenadering. Een belangrijke conclusie uit Van Bakel en Stuyt (2011) was dat het starre

\footnotetext{
${ }^{3}$ http://www.stowa.nl/Upload/agenda/20142606\%20ZZ\%20tweedaagse/Presentatie\%20Lodewijk\%20Stuyt,\%20Zouttolerantie\% 20groter\%20dan\%20gedacht_.pdf
} 
zoetwaterbeheer vervangen zou moeten worden door een flexibele, adaptieve variant. Dat betekent: loslaten van rigide normen en de gebruikers, gegeven actuele situatie, op juiste plek, op het juiste moment, genoeg water met de vereiste kwaliteit leveren.

\subsection{Irrigatie- en zoutschade}

Onder zilte omstandigheden kan de manier van irrigeren van belang zijn voor het effect van zout op de plant. Bij de aardappelteelt op ruggen kan het natrium in het beregeningswater op verschillende manieren ophopen in de wortelzone. Figuur 5 toont verschillende zoutaccumulatieprofielen bij verschillende manieren van watertoediening. Het bodemtype speelt hierbij een belangrijke rol.

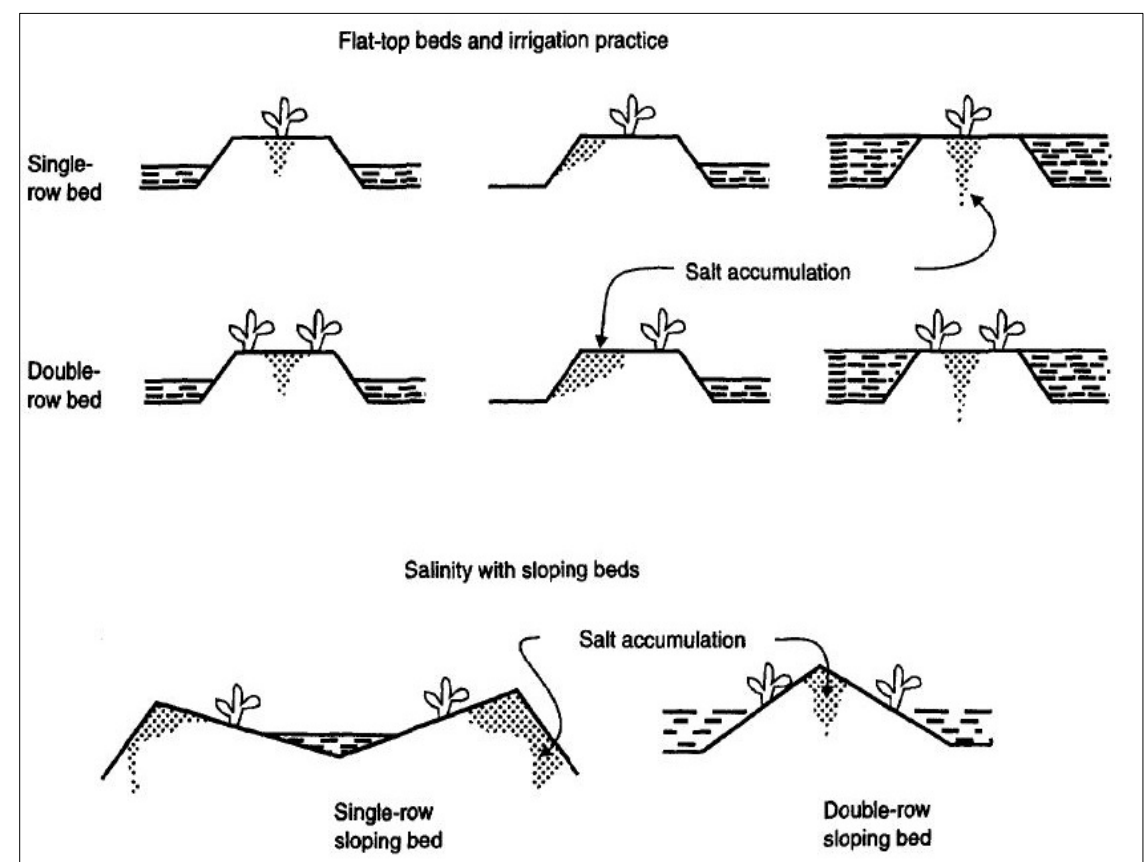

Figuur $5 \quad$ Zoutaccumulatiepatronen in een ruggenteelt bij verschillende manieren van irrigeren van de voren (Hillel, 2000).

Beregening met sprinklers (Figuur 6) kan bladverbranding veroorzaken, waardoor de fotosynthese en de assimilatie worden geremd, en/of verbranding en verkleuring van oogstbare producten optreedt.

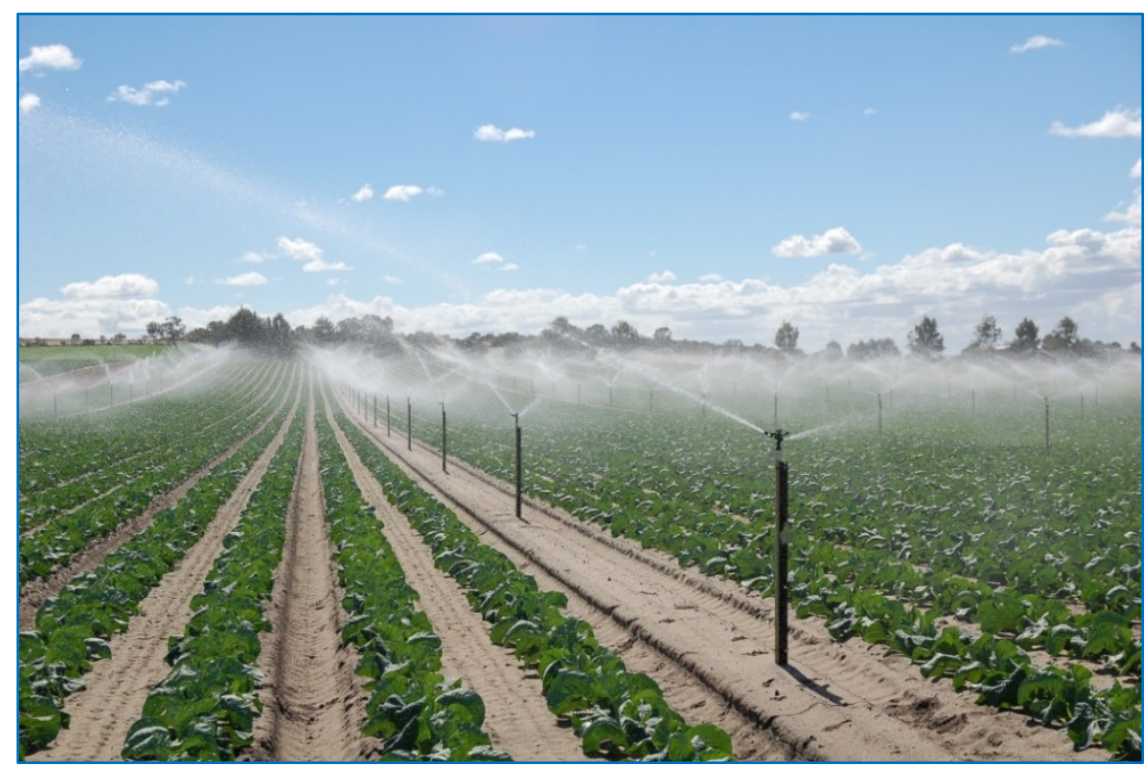

Figuur 6 Het gebruik van sprinklers bij beregening kan bladverbranding veroorzaken. 


\section{$2.5 \quad$ Structuurbederf}

Behalve schade aan een gewas kan beregening met water met een verhoogd zoutgehalte ook nadelige effecten hebben op de bodemstructuur. Daarbij gaat het over ongewenste reacties van de bodem. Het belangrijke aspect van beregening met water met verhoogd zoutgehalte is structuurbederf van de grond. Om dit te begrijpen wordt kort ingegaan op de belangrijkste processen die hierbij een rol spelen (Locher en de Bakker, 1990). De lutumfractie (fractie $<2 \mu \mathrm{m}$ ) in kleigronden bestaat hoofdzakelijk uit plaatvormige minerale deeltjes de zogenaamde kleimineralen. Deze deeltjes bezitten van nature vaak een positieve elektrische lading aan de randen van de platen en een negatieve lading aan de plaatzijde. Losse kleideeltjes in een grondsuspensie worden door zogenaamde London- van der Waalskrachten naar elkaar toegetrokken. De overwegend negatieve ladingen drijven de deeltjes echter uit elkaar. De positieve randlading toont neiging contact te maken met de negatieve valenties van de platen. Wanneer de negatieve ladingen voldoende geneutraliseerd worden door kationen, dan kunnen ook de platen elkaar dicht naderen. Opgeloste zouten in de bodemoplossing hebben de neiging te ioniseren, dwz te splitsen in positieve en negatieve ionen, respectievelijk kationen en anionen. Voor keukenzout kan dit proces als volgt voorgesteld worden:

$\mathrm{NaCl} \leftrightarrow \mathrm{Na}^{+}+\mathrm{Cl}^{-}$

De mate van uiteenvallen in ionen, dissociatie- of ionisatiegraad genoemd, is voor verschillende zouten verschillend. Natriumzouten ioniseren sterk, calciumzouten zoals koolzure kalk en calciumsulfaat of gips, zwak. Per eenheid van lading bezit het positieve natriumion een dikkere watermantel dan de tweewaardige calcium- en magnesiumionen. De positieve kationen worden aangetrokken door de overwegend negatief geladen kleideeltjes van het adsorptiecomplex en vormen daarmee de zogenaamde elektrische dubbellaag (van kationen met hun water- of hydratatiemantel). Hoe dikker de dubbellaag, des te minder groot de aantrekking tussen de kleideeltjes zal zijn. Bij een dikke dubbellaag zweven de kleideeltjes los van elkaar (peptisatie); bij een dunne dubbellaag worden vlokken of aggregaten gevormd (coagulatie). Een hoge zoutconcentratie in het bodemvocht en een hoge waardigheid van de kationen in de dubbellaag hebben een relatief dunne dubbellaag tot gevolg. Een lage zoutconcentratie in de bodemoplossing daarentegen en een lage waardigheid van de kationen geven een dikke dubbellaag (peptisatie) (Nieuwenhuizen et al., 2003).

In een kleigrond die na overstroming met zout water droogvalt, zijn de $\mathrm{Ca}^{2+}{ }^{2}$-ionen aan het adsorptiecomplex voornamelijk vervangen door $\mathrm{Na}^{+}$-ionen. Wanneer nu door regenval de zoutconcentratie in het bodemvocht daalt, dan zal peptisatie en zwelling (uitzetting van de dubbellaag) optreden. De grond zal slempgevoelig zijn en zwel- en krimpverschijnselen vertonen. Natriumhoudende kleigronden kunnen hierdoor bij natte omstandigheden ondoorlatend worden, waardoor natschade aan het gewas kan ontstaan en de grondbewerking wordt bemoeilijkt. Ineengeslempte gronden drogen steenhard op, met eveneens mogelijke schadelijke gevolgen voor grondbewerking en gewasgroei (Hissink, 1954).

Een goede maat voor het risico op structuurbederf, veroorzaakt door irrigatiewater, is de Sodium Adsorption Ratio (SAR) van irrigatiewater, die wordt berekend als:

$$
\mathrm{SAR}=\frac{\mathrm{Na}^{+}}{\sqrt{\frac{\mathrm{Ca}^{2+}+\mathrm{Mg}^{2+}}{2}}}
$$

In deze betrekking worden de concentraties van de ionen $\mathrm{Na}^{+}, \mathrm{Ca}^{2+}$ en $\mathrm{Mg}^{2+}$ uitgedrukt in milli-equivalenten per liter. 'EC' staat voor Electric Conductivity (Elektrisch Geleidingsvermogen, EGV) en is een veel gebruikte maat voor de hoeveelheid in water opgeloste ionen. Zoals uit Figuur 7 kan worden afgelezen is de combinatie van een hoge SAR en een lage EC riskant voor de structuurstabiliteit van de bodem. 


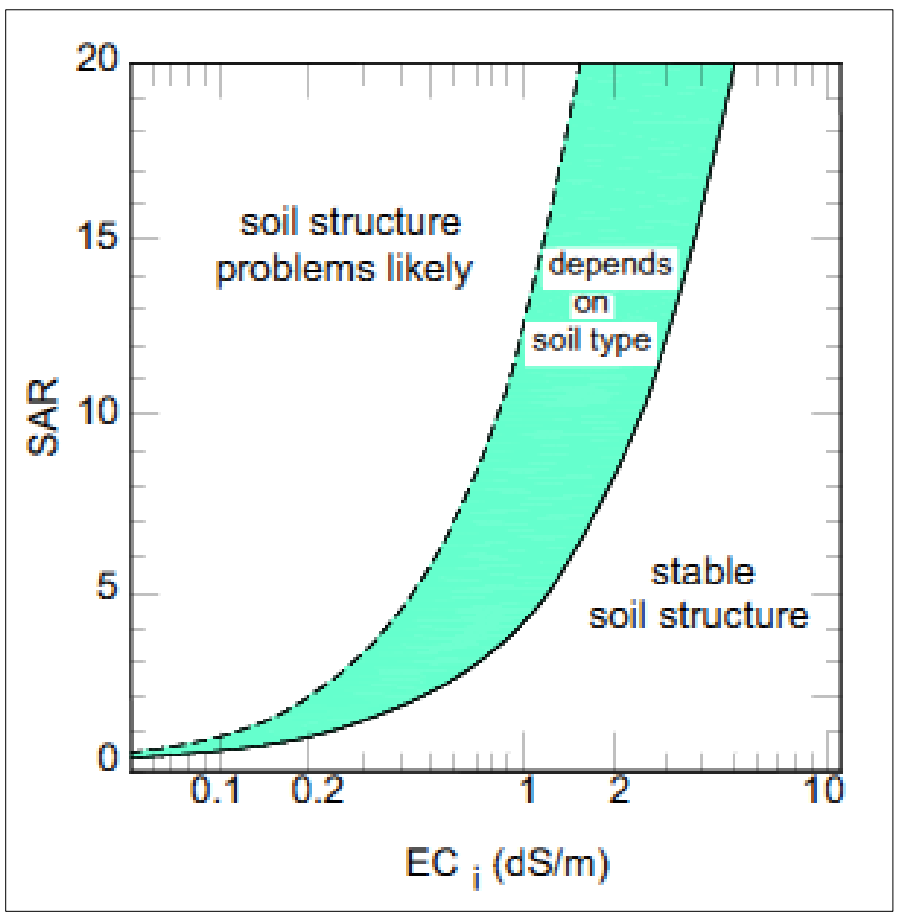

Figuur 7 Relatie tussen SAR en EC van irrigatiewater en kans op structuurschade ${ }^{4}$.

\subsection{Zoutschadedrempels}

Zoals al in het historisch overzicht is beschreven, zijn in navolging van het werk van de Amerikaanse onderzoekers Maas en Hoffman de gewassen ingedeeld in vier zoutgevoeligheidsklassen (gevoelig, matig gevoelig, matig tolerant en tolerant); zie Figuur 8.

\section{FIGURE A1.1}

Division for classifying crop tolerance to salinity

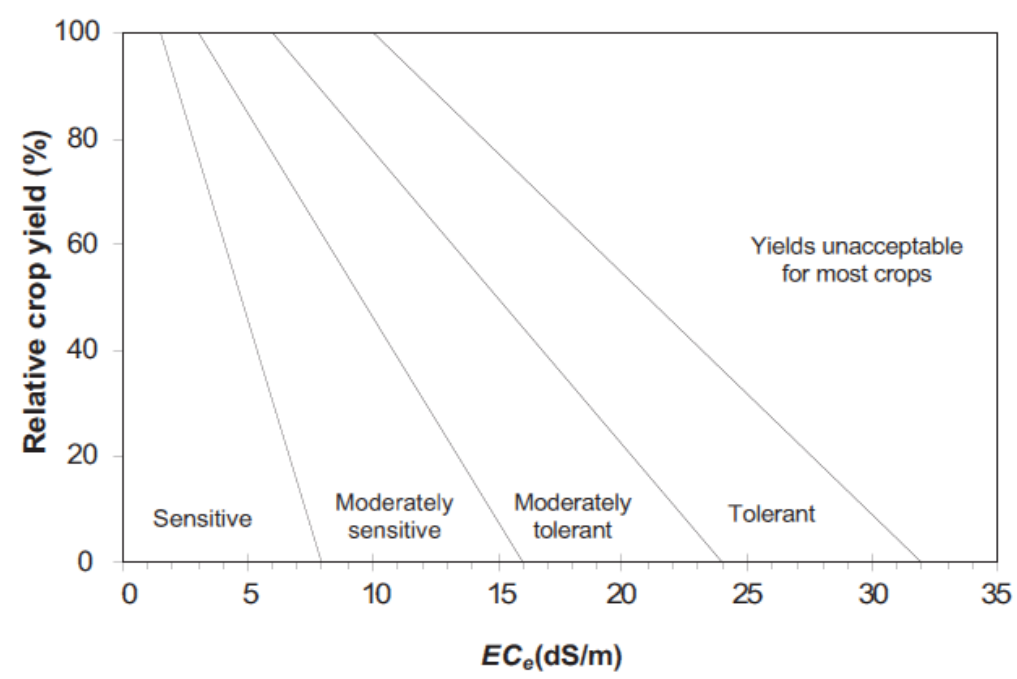

Figur 8 Vier zoutgevoeligheidsklassen van planten (gevoelig, matig gevoelig, matig tolerant en tolerant) in relatie tot het zoutgehalte waaraan zij worden blootgesteld.

\footnotetext{
4 Bron: http://www.optimaagriculture.com.au
} 
Per klasse zijn relaties afgeleid tussen de EC en de relatieve gewasopbrengst. Deze relaties worden gekarakteriseerd door twee parameters:

1. De zoutschadedrempel. Dit is de EC van het water in de wortelzone waarbij schade aan het gewas begint op te treden; het knikpunt van de doorgetrokken lijn in Figuur 9;

2. De zoutschadegevoeligheid, gedefinieerd als de procentuele daling van de gewasopbrengst door zoutschade per eenheid van toename van de seizoensgemiddelde EC in de wortelzone boven de zoutschadedrempel; de hellingshoek $\mathrm{EC}_{\text {slope }}$ in Figuur 9.

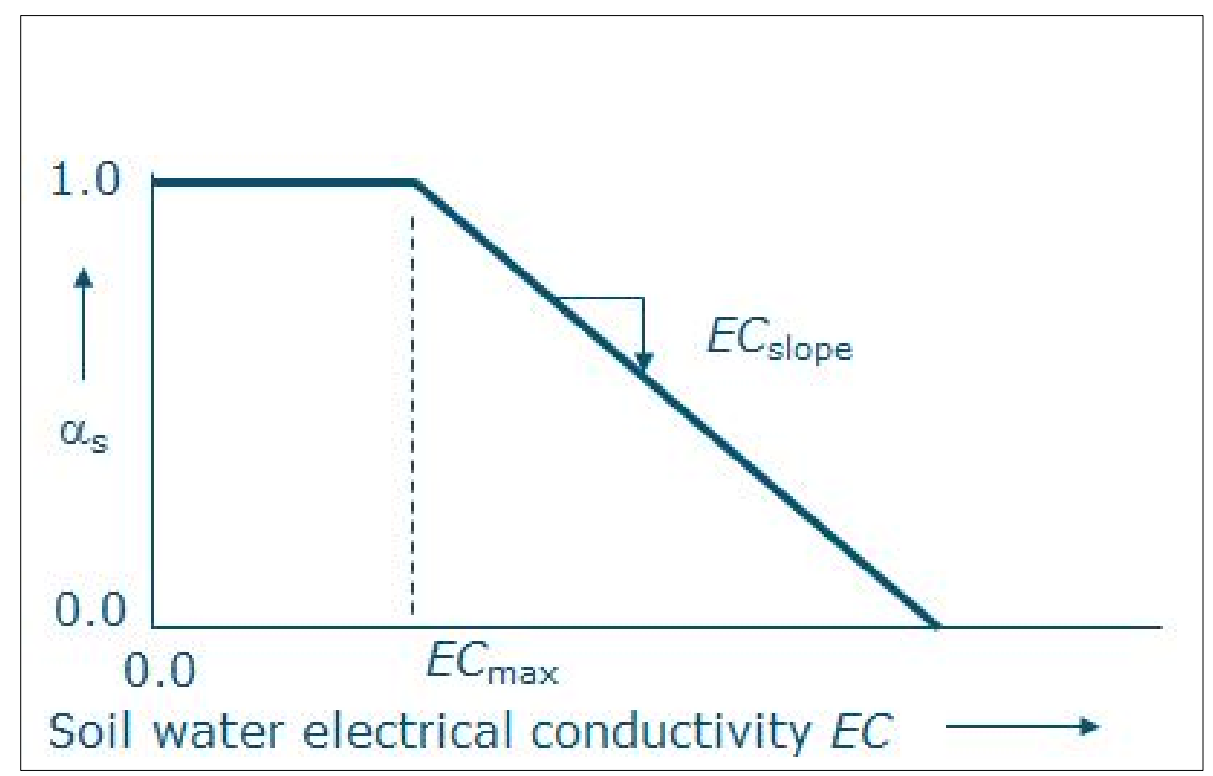

Figuur 9 Relatie tussen de EC en de relatieve gewasopbrengst. Deze relaties worden gekarakteriseerd door waarden van de zoutschadedrempel en de zoutschadegevoeligheid, hier weergegeven als de helling 'EC slope'; zie tekst.

Op basis van de in de literatuur vermelde relaties is een tabel opgesteld met waarden voor beide parameters, voor elk van de vier zoutgevoeligheidsklassen.

De berekening van de zoutschadedrempels met de Maas-Hoffmanvergelijking is gebaseerd op de veronderstelling dat de gevoeligheid van gewassen voor zout in alle groeistadia gelijk is. Van een ruim aantal cultuurgewassen is echter bekend dat de gevoeligheid in de diverse groeistadia sterk kan variëren. Het betrouwbaarheidsinterval van een zouttolerantiedrempel wordt gekenmerkt door een waardeninterval ('bandbreedte'). Het is nodig om de effecten van factoren als plantleeftijd tijdens de blootstelling aan zout, duur van de blootstelling, zoutconcentratie in de wortelzone, bodemkarakteristieken, ontwateringstoestand getalsmatig en eenduidig met dit waardeninterval in verband te brengen. Welke factoren werken drempelverlagend (i.c. grotere zouttolerantie) en welke drempelverhogend (i.c. kleinere zouttolerantie), en in welke mate? Hoe implementeren we deze nieuwe informatie in het operationele zoetwaterbeheer?

\subsection{Simulatiemodel SWAP}

SWAP $^{5}$ (Soil-Water-Atmosphere-Plant) is een veelgebruikt simulatiemodel dat in eerste instantie is ontwikkeld voor het bepalen van de actuele verdamping als functie van meteorologische gegevens, gecombineerd met gewas- en bodemgegevens; zie Figuur 10.

\footnotetext{
${ }^{5}$ http://www.swap.alterra.nl
} 


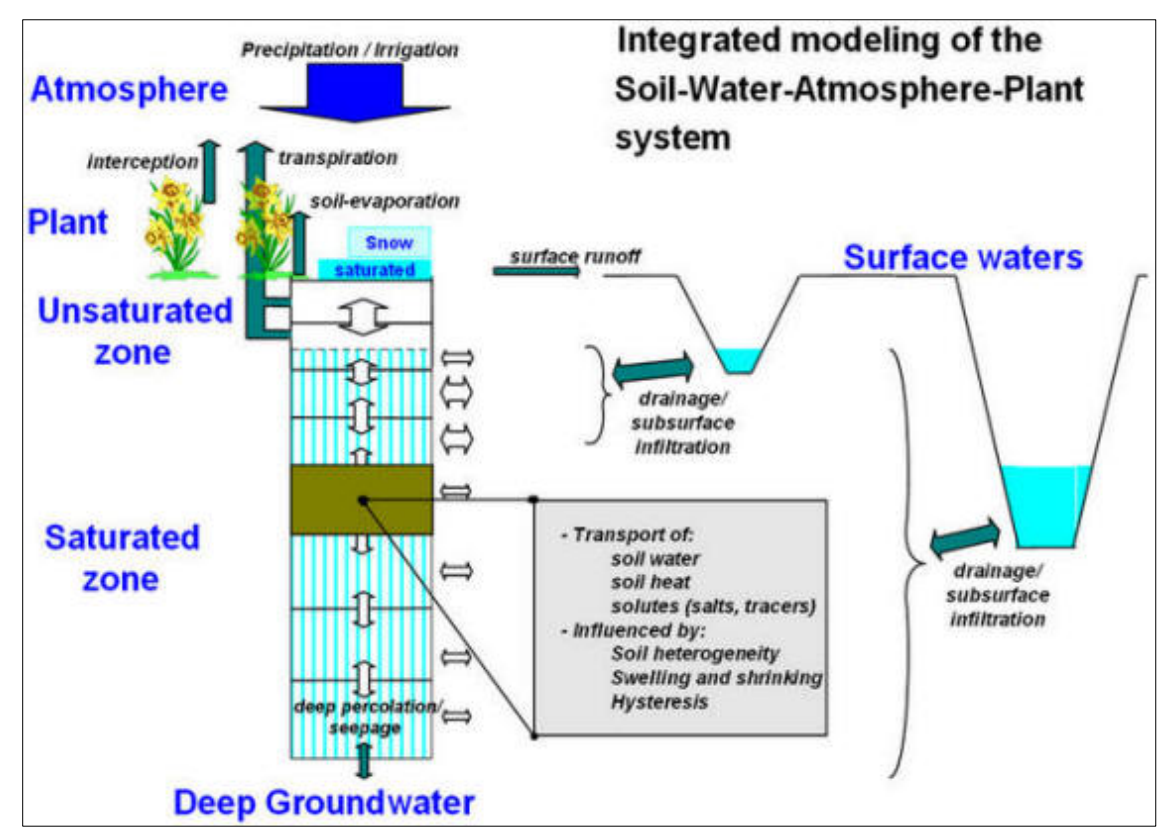

Figuur 10 Modelconcept SWAP (Bron: http://www.swap.alterra.nl).

Het model simuleert processen in het zogeheten topsysteem, ofwel het onverzadigde en verzadigde bovenste deel van de bodem, waar de interactie tussen grond- en oppervlaktewater op perceelschaal van belang is. Zo worden met het model SWAP voor dit topsysteem het transport van water, opgeloste stoffen en de bodemtemperatuur berekend. Met dit model kan de water- en zoutbeweging ééndimensionaal (i.c. verticaal) worden gesimuleerd, dus is op elk moment modelmatig bekend welke hoe hoog de zoutconcentraties in de onderscheiden compartimenten zijn. Het model is daarmee in staat de osmotische werking van zout in de wortelzone en de gevolgen voor de wateropname in beeld te brengen. SWAP berekent afzonderlijk reductiefactoren voor wortelvochtopname als gevolg van zout (Maas-Hoffman, 1977) en door droogte of zuurstofstress (Feddes et al., 1978).

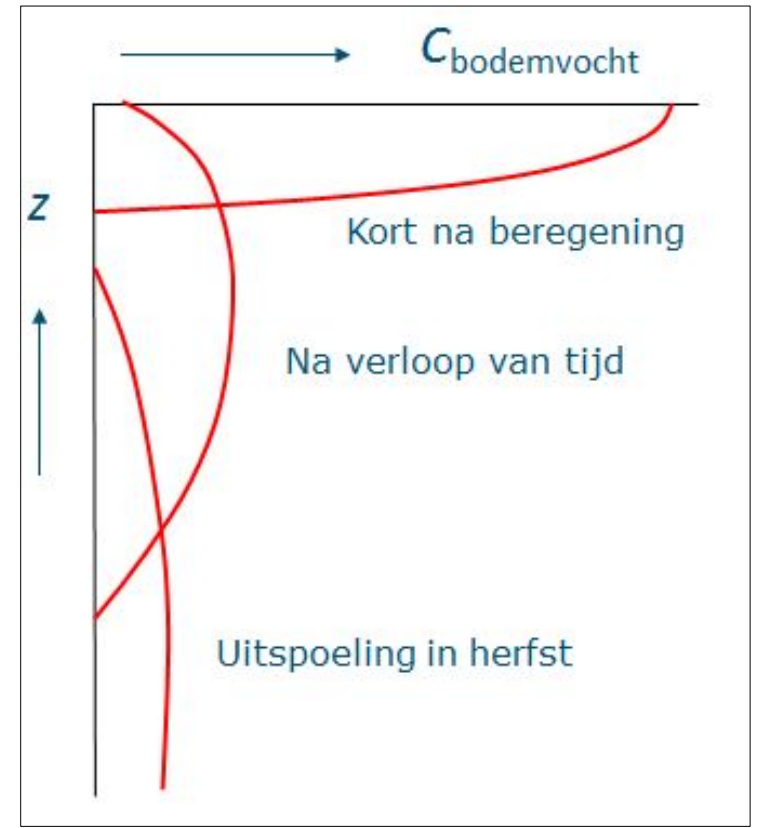

Figuur 11 De verandering, met de tijd, van het zoutgehalte van bodemvocht ( $C_{\text {bodemvocht }}$ ) met de diepte beneden maaiveld $(Z)$, in drie stadia in het humiede Nederlandse klimaat: kort na een beregening, na verloop van tijd, en tijdens uitspoeling, veroorzaakt door neerslag. De concentratie van het zoutgehalte van het bodemvocht verplaatst zich in deze volgorde in neerwartse richting en neemt tegelijkertijd af. Bij voldoende neerslag is het zout na de winter meestal goeddeels uitgespoeld. 
Bij open teelten onder Nederlandse omstandigheden kan natuurlijke neerslag grote invloed hebben op het zoutprofiel van de bodem; zie Figuur 11. Als de hoeveelheid neerslag tijdens het groeiseizoen niet verwaarloosbaar klein is kan het zoutgehalte van het bodemvocht geregeld (tijdelijk) door de neerslag worden verlaagd. Deze hypothese is getoetst en bevestigd door middel van berekeningen met SWAP. Voor een aantal gewassen en bodems is het verloop van de concentratie in het bodemvocht berekend, op basis van weersgegevens voor de jaren 1971-2000; zie Figuur 12, ontleend aan Bakel et al.

(2009). Uit de berekeningen bleek dat de zoutconcentratie in het bodemvocht alleen in de extreem droge zomer van 1976 hoger was dan de concentratie in het irrigatiewater. In alle andere zomers bleek sprake te zijn van 'verdunning' van het irrigatiewater, met als resultaat afnemende zoutconcentraties in het bodemvocht.

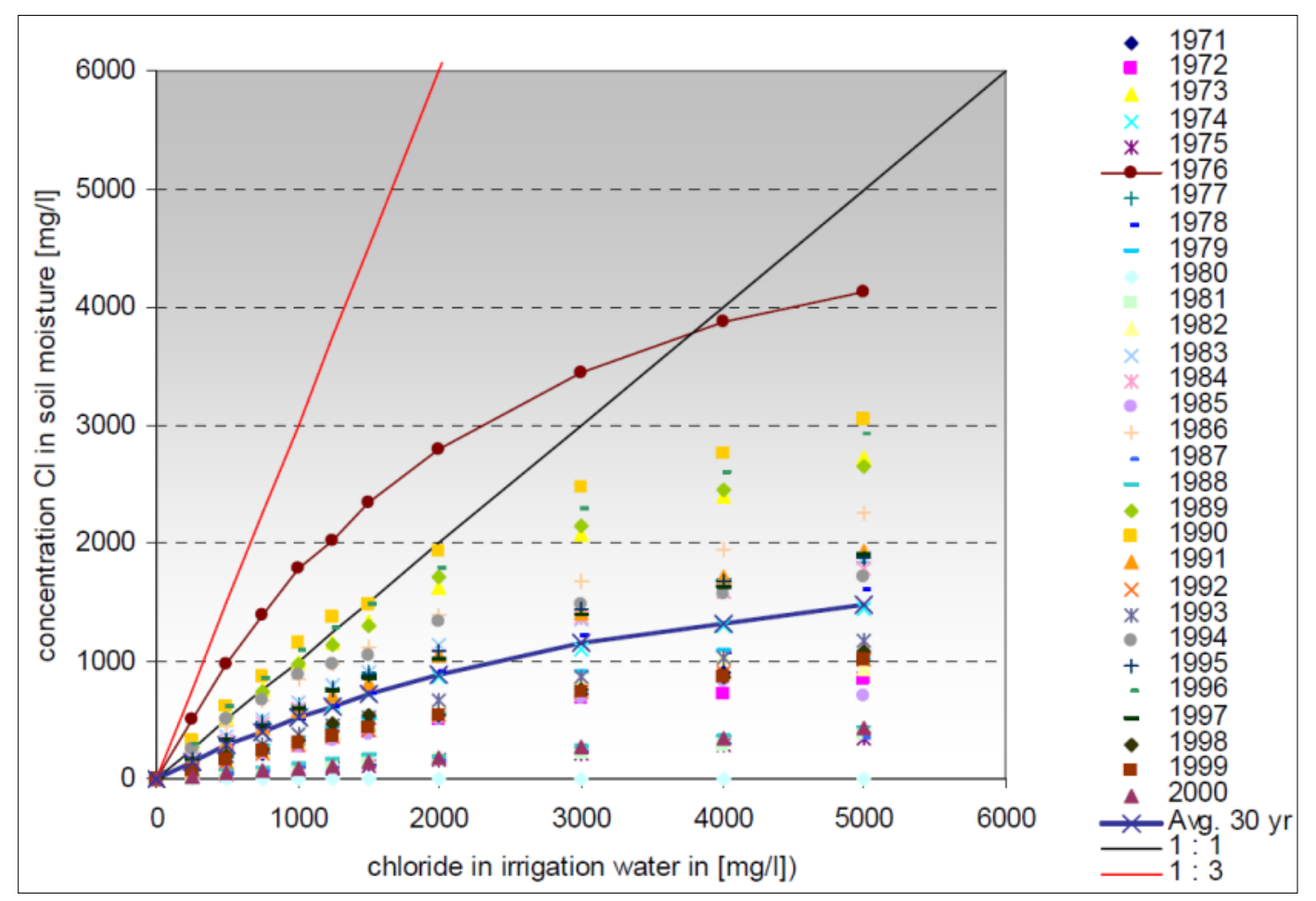

Figuur 12 Het verband tussen de gemiddelde chlorideconcentratie in het bodemvocht in de wortelzone ( $\mathrm{mg} / \mathrm{I})$; verticale as, en in het irrigatiewater (horizontale as), voor aardappel op zandgrond. Bron: Bakel et al. (2009).

SWAP gaat uit van een homogene bodem en een - ruimtelijk gezien - uniforme irrigatiegift. Verhoeven (1953) wijst echter op de grote ruimtelijke variabiliteit van vochtgehalte, zoutgehalte en samenstelling van de zoutoplossing in de bodem. Zelfs bij het nemen van een groot aantal monsters is het daardoor niet altijd mogelijk een representatief beeld te krijgen van de zouttoestand in de wortelzone van het gewas (zie Figuur 13, ontleend aan Verhoeven 1953). De verdeling van irrigatiewater over een bodemprofiel is niet uniform. Een uniformiteit tussen de 60 en $84 \%$ wordt als (zeer) goed bestempeld. Bij een uniformiteit van $70 \%$ (dus op de grens van 'goed' en 'zeer goed') is ruwweg $15 \%$ van het oppervlak te nat en $15 \%$ te droog. 


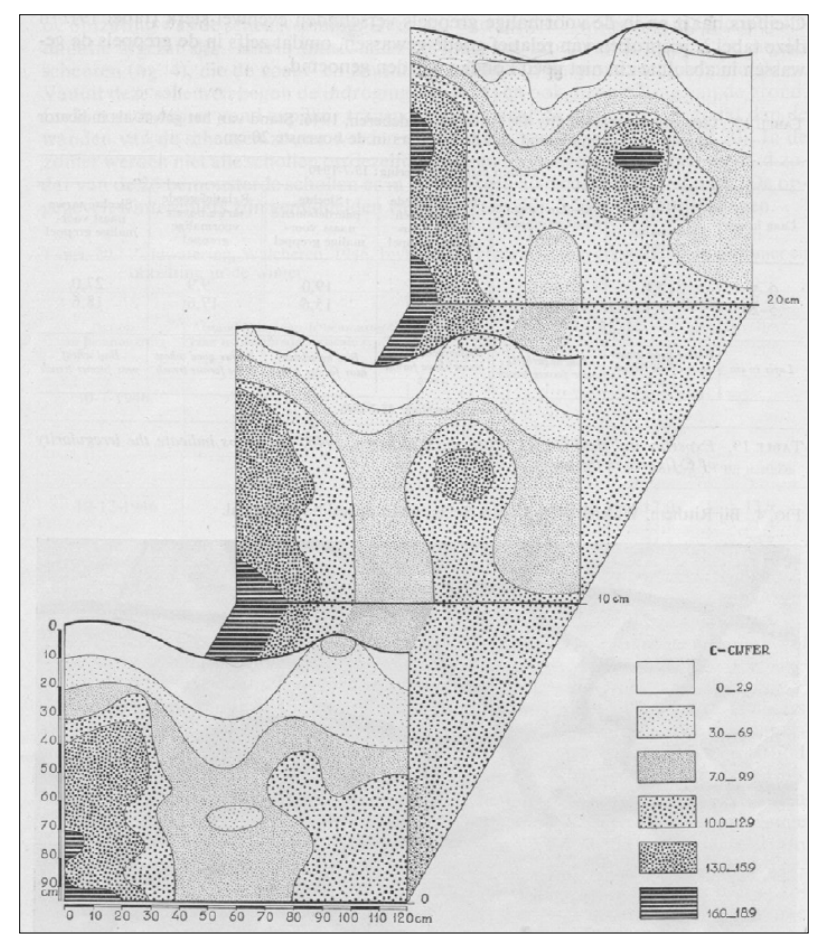

Figuur 13 Kenmerkende verdeling van het 'C-cijfer', te weten de zoutconcentratie in gram per 1000 gram bodemwater ( $\approx 1$ liter bodemwater) op korte afstanden in een bodemsegment met afmetingen 1,2×1,0×0,2 m, in de Oost-Bevelandpolder, op 1 mei 1947. Bron: Verhoeven (1953).

Model SWAP simuleert overigens alleen het osmotisch effect van natrium. Er wordt geen rekening gehouden met de dynamiek in de gewasgroei, het toxische effect van natrium op de fotosynthese en de potentie van een gewas om zich aan zijn veranderende omgeving aan te passen. Om rekening te kunnen houden met deze dynamiek van gewasgroei wordt SWAP in het project Waterwijzer ${ }^{6}$ gekoppeld aan het groeimodel WOFOST (World Food Studies) ${ }^{7}$. In WOFOST wordt de potentiele gewasgroei berekend als functie van het $\mathrm{CO}_{2}$-gehalte, de zonnestraling, de temperatuur en gewaskenmerken. Gewasrespons en schade bij verzilting zijn echter vooralsnog niet in dit model meegenomen.

\subsection{De beregening van landbouwgewassen}

In deze bureaustudie staat de beregening van landbouwgewassen, in de vorm van gietwater, met behulp van sprinklers, door middel van druppelirrigatie en dergelijke, centraal. Het is daarom belangrijk om informatie in te winnen over de mate waarin bepaalde gewassen worden beregend. Op basis van landbouwmeitellingen uit 1995, 1997 en 1999 heeft het Landbouw Economisch Instituut (LEI) beregeningsactiviteiten geïnventariseerd, als percentage van het de totale oppervlakte cultuurgrond (Hoogeveen et.al., 2003). In het kader van de ontwikkeling van het Nationaal Hydrologisch Instrumentarium heeft Massop (2013) de landelijke potentiële beregeningskaart geactualiseerd. Deze actualisatie is gebaseerd op de landbouwmeitellingen uit 2010. Deze meitellingen bevatten de meest recente informatie over de beregende arealen, geregistreerd tussen april 2007 en maart 2010. Vergelijking met informatie van landbouwmeitellingen uit het rapport van Hoogeveen uit 2003 laat zien dat het beregende areaal tussen 2003 en 2010 is toegenomen (Figuur 14), vooral in de IJsselmeerpolders, de kop van Noord-Holland en de Zuid-Hollandse Eilanden (Massop, 2013).

\footnotetext{
www.waterwijzer.nl

www.wageningenur.nl/en/expertise-services/research-institutes/alterra/facilities-products/software-andmodels/wofost.htm
} 


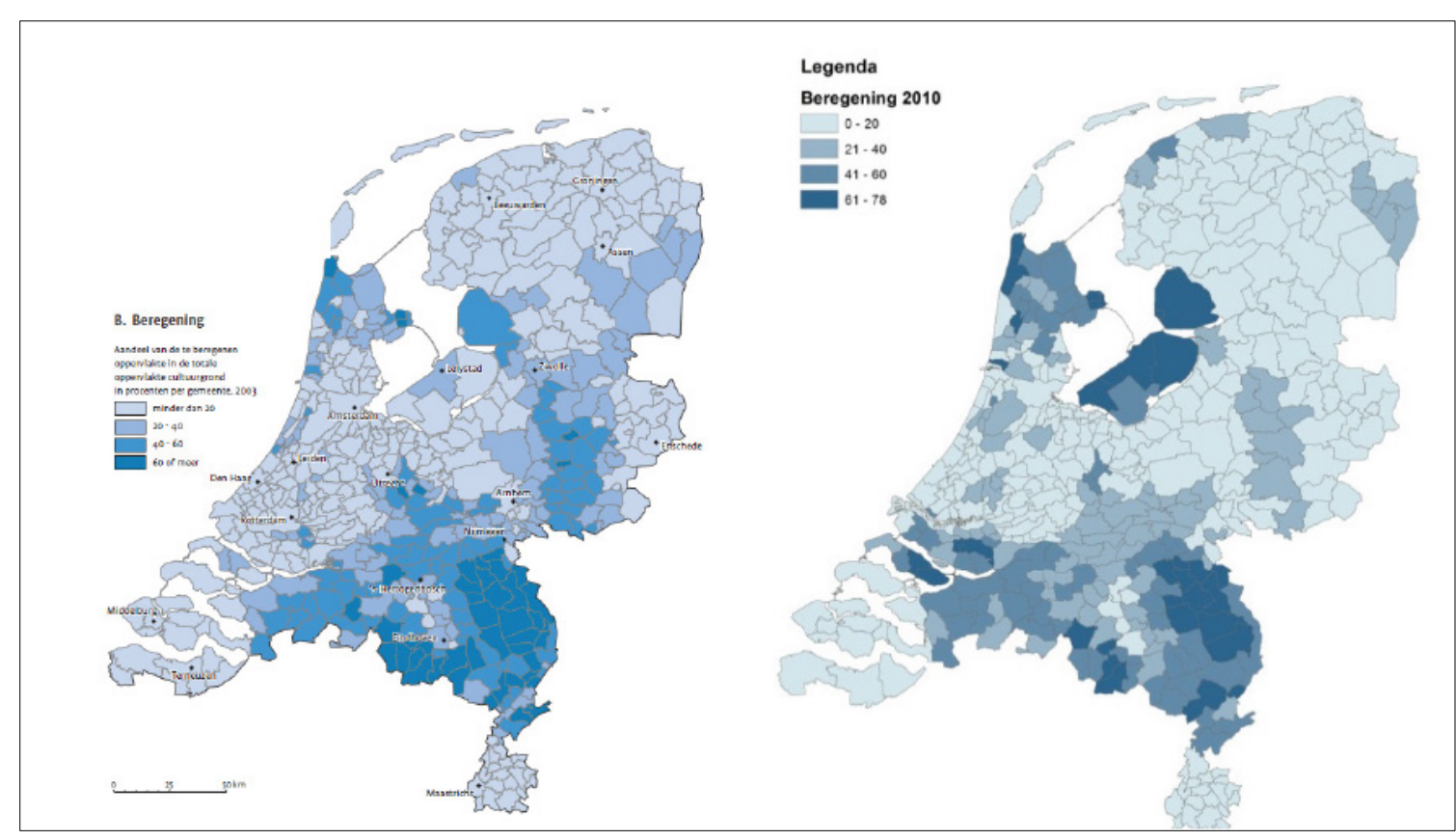

Figuur 14 Percentage van het totale areaal cultuurgrond dat wordt beregend in 2003 (links) en 2010 (rechts). Bron: Massop (2013).

Naast de beregende arealen in Nederland is ook de volgende informatie geregistreerd: het gewastype, de watergift in $\mathrm{mm}$, het type beregening en de soort waterbronnen die voor irrigatie zijn gebruikt. Onder het type beregening vallen naast 'sproeien' ook oppervlakte irrigatie en druppelbevloeiing. Door informatie uit de BRP-percelen (Basisregistratie Percelen, RVO2010), die gebruikt is voor bepaling van het totaal areaal, te koppelen aan de Geografische Informatie Agrarische Bedrijven (GIAB2010, Alterra) waarin de beregeningsgegevens zijn opgeslagen, werd inzicht verkregen in het percentage beregend areaal per gewassoort. 


\section{Inventarisatie zoutschade op basis van bestaande gegevens}

\subsection{Inleiding}

Deze bureaustudie, waarin de bestaande informatie rond de zouttolerantie van onder Nederlandse omstandigheden geteelde landbouwgewassen is geïnventariseerd, is uitgevoerd conform onderstaande beschrijving. De grote hoeveelheid voorliggende informatie werd gestructureerd, gestroomlijnd en geanalyseerd in een hiervoor in Excel ontwikkelde database.

In Nederland is het gewoonte om een zoutgehalte uit te drukken in mg chloride per liter volledig ingeburgerd; deze bij ons herkenbare rekeneenheid is ook in deze rapportage gebruikt ${ }^{8}$.

Zoutschade aan landbouwgewassen kan worden gekoppeld aan het zoutgehalte van beregeningswater of het zoutgehalte van (het bodemwater in) de wortelzone. In dit onderzoek was de aandacht gericht op het zoutgehalte van beregeningswater. Er is doelbewust gezocht naar gerapporteerde drempelwaarden van het chloridegehalte in beregeningswater waarbij een gewas nog (net) geen zoutschade oploopt. Deze keuze is gemaakt omdat deze drempelwaarde in de praktijk van het operationele waterbeheer in verziltingsgevoelige regio's een belangrijke rol speelt.

Een gerapporteerde zoutschadedrempel is het cumulatieve resultaat van een groot aantal effecten van (doorgaans bewust gekozen) randvoorwaarden die elkaar niet (of weinig) beïnvloeden; in dit geval het soort gewas, het groeistadium, de grondsoort, de watervoorziening, de aan/afwezigheid van zoute kwel, de vochttoestand van de grond, het al dan niet gedraineerd zijn van het perceel enzovoort. Van de 35 gewassen en gewasgroepen die in deze bureaustudie zijn geïdentificeerd hebben diverse autonome onderzoekers één (of meerdere) drempelwaarde( $n$ ) voor het zoutgehalte van beregeningswater vastgesteld. $\mathrm{Zij}$ hebben hun experimenten uitgevoerd met verschillende aannames en onder uiteenlopende omstandigheden, en wel (i) door meting onder veldomstandigheden, (ii) door meting in opstellingen in kassen, al dan niet in potproeven, (iii) door berekening met behulp van computersimulatiemodellen, (iv) op grond van expertkennis en (v) door combinaties van (i) - (iv). In Nederland zijn diverse brochures, memo's e.d. in omloop waarin informatie wordt verstrekt over de zouttolerantie van gewassen, en die soms al jaren door belanghebbenden worden geraadpleegd. Een simpel voorbeeld is weergegeven als Tabel 2, ontleend aan de proefstations voor tuinbouw onder glas en voor de bloemisterij en IKC Afd. Glasgroente en bestuiving (1991), waarin diverse toleranties worden gespecificeerd. Dit gebeurt echter slechts in zeer algemene termen; er worden geen drempels genoemd, noch wordt informatie verstrekt over de omstandigheden waar de toleranties mee geassocieerd zouden kunnen zijn, bijvoorbeeld de teeltmethode, het bodemtype, diverse vormen van substraatteelt; de gietmethode: druppelbevloeiing, regenleiding, eb-vloedsysteem etc. Ook worden geen bronnen genoemd waaraan de kennis ontleend werd; vermoed wordt dat dit vooral praktijkervaring betreft (van 25 jaar geleden).

\footnotetext{
${ }^{8} \mathrm{Er}$ is een trend gaande om over te schakelen op het Elektrisch Geleidingsvermogen (EGV), oftewel EC (=Electric Conductivity), een werkwijze die in deze 'branche' buiten Nederland vanzelfsprekend is.
} 
Tabel 2 Opgave van de 'zoutgevoeligheid' van gewassen bij tuinbouw onder glas en bloemisterij. Bron: proefstations voor tuinbouw onder glas en voor de bloemisterij en IKC Afd. Glasgroente en bestuiving (1991).

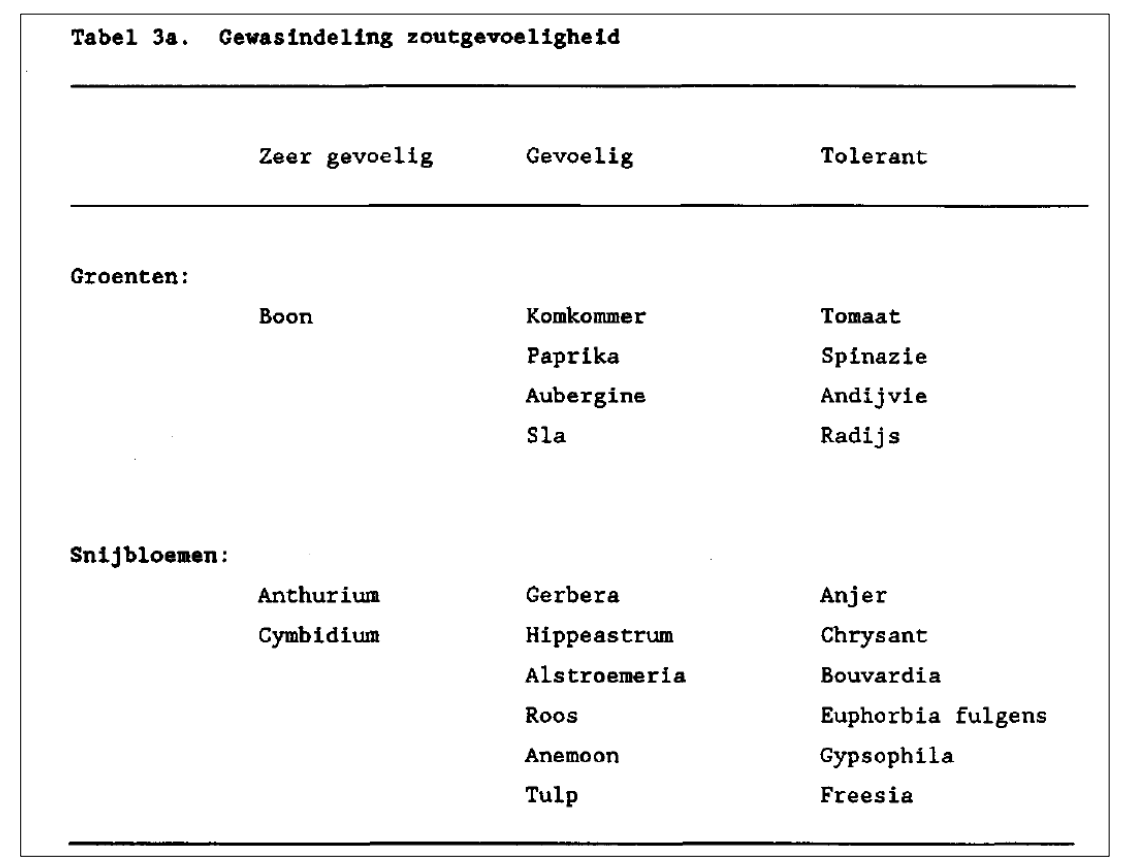

Bij de zoektocht naar bruikbare informatie is opgevallen dat bovenstaand voorbeeld geen uitzondering is, maar dat in veel gevallen slechts kwalitatieve informatie wordt verstrekt. Een goed voorbeeld hiervan, ontleend aan Deckers en Vergote (2006), afkomstig uit België: 'Als algemene beoordeling van de EC kan men volgende normen aanhouden: $<0,8 \mathrm{mS} / \mathrm{cm}=$ gunstig; 0,8-1,2 $\mathrm{mS} / \mathrm{cm}=$ gunstig indien hoofdzakelijk voedingselementen, problemen indien $\mathrm{Na}$ of $\mathrm{Cl}$ te hoog zijn; 1,2-1,5 $\mathrm{mS} / \mathrm{cm}=$ probleemwaters, enkel te gebruiken voor zoutverdragende gewassen zoals bloemkolen of selderij; $>1,5 \mathrm{mS} / \mathrm{cm}=$ voor tuinbouw niet bruikbaar, voor weinig gevoelige landbouwteelten of voor grasland mogelijk nog bruikbaar. Bij een te hoge EC zijn er vooral problemen te verwachten als er te veel natrium en chloriden in het water aanwezig zijn.

Niet elke teelt is even gevoelig voor zout water. Wortelen en prei zijn bijvoorbeeld weinig gevoelig, aardappelen en koolsoorten zijn dan weer matig gevoelig. Ook voor de fruitteelt zal men moeten beschikken over water met een laag zoutgehalte. Peren verdragen meer zout dan appels. In principe kan bij de beregening boven de bomen voor nachtvorstbestrijding tamelijk zout water gebruikt worden. In dat geval kunnen ongewenste zouten echter accumuleren in de bodem en een negatieve invloed uitoefenen op de productie en de kwaliteit van het fruit. (...) De Bodemkundige Dienst van België geeft op basis van een analyse van het irrigatiewater een advies of het water al dan niet geschikt is als irrigatiewater voor teelten in open lucht.'

\subsection{Beschrijving werkwijze}

In onze bureaustudie zijn alleen publicaties meegenomen waarin de resultaten van nieuw onderzoek zijn gerapporteerd; citaten, te weten referenties naar eerder verschenen publicaties, zijn genegeerd. Hierop is slechts één uitzondering gemaakt, te weten de meest recente specificaties die werden gevonden, zijnde de in 2015 door Eurofins Agro Laboratories (Wageningen) in een vijftal informatiebladen voor diverse categorieën (akkerbouw, boomkwekerij, fruitteelt, glastuinbouw, groententeelt vollegrond) gespecificeerde zouttolerantiedrempels. De reden dat de informatiebladen van Eurofins niet zijn genegeerd is dat zij door telers en agrariërs anno 2016 worden geraadpleegd. Desgevraagd kon Eurofins overigens niet de bron(nen) noemen van de in deze informatiebladen gespecificeerde drempelwaarde $(n)^{9}$. Zij werden vermoedelijk (deels) ontleend aan van Bakel en Stuyt (2011).

\footnotetext{
9 J. Hardeman (Eurofins Agro), persoonlijke mededeling dd. 15 juli 2016.
} 
Tabel 3 geeft voor 35 gewassen en gewasgroepen informatie over het aantal nieuwe zouttolerantiedrempels dat in deze bureaustudie boven tafel is gekomen, op welke pagina in dit rapport gedetailleerde informatie beschikbaar is, het aantal keren dat een zouttolerantiedrempel in latere publicaties is geciteerd en een overzicht van de jaren waarin nieuwe drempelwaarden werden geïntroduceerd.

Tabel 3 Informatie over de gerapporteerde zouttolerantiedrempels van 35 geïdentificeerde gewassen en gewasgroepen, gemeten in beregeningswater, het aantal nieuwe zouttolerantiedrempels dat in deze bureaustudie boven tafel is gekomen, op welke pagina in dit rapport gedetailleerde informatie beschikbaar is, het aantal keren dat een zouttolerantiedrempel in latere publicaties is geciteerd en de jaren waarin nieuwe drempelwaarden voor het chloridegehalte van beregeningswater zijn voorgesteld.

\begin{tabular}{|c|c|c|c|c|c|c|c|c|c|c|c|c|c|c|c|c|c|c|c|}
\hline \multirow[b]{2}{*}{ No } & \multirow[b]{2}{*}{ Gewas(groep) } & \multirow{2}{*}{$\begin{array}{l}\text { Details op } \\
\text { pagina }\end{array}$} & \multicolumn{2}{|c|}{ Aantal drempels } & \multicolumn{15}{|c|}{$\begin{array}{l}\text { Introductiejaar nieuwe drempelwaarde( } n \text { ) } \\
\text { (bij benadering) }\end{array}$} \\
\hline & & & nieuw & geciteerd & $\frac{10}{\circ}$ & 욜 & 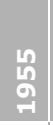 & ஜ & 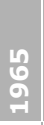 & $\stackrel{\circ}{\stackrel{2}{+}}$ & คे & \begin{tabular}{c|}
$\circ$ \\
के \\
ने
\end{tabular} & $\stackrel{10}{\infty}$ & $\begin{array}{l}8 \\
\text { के } \\
\text { मे }\end{array}$ & है & 요 & ำ & 웅 & 를 \\
\hline 1 & Grasland & 48 & 10 & 5 & & $x$ & & & & $x$ & & & & & $\times$ & & & & \\
\hline 2 & Tarwe, gerst & 49 & 11 & 6 & & $x$ & & & & $x$ & & & & & & & & & $x$ \\
\hline 3 & Klaver (Luzerne) & 54 & 1 & - & & $x$ & & & & & & & & & & & & & \\
\hline 4 & Snijmais & 56 & 7 & 2 & & & & & & & & & & & & & & $x$ & \\
\hline 5 & $\begin{array}{l}\text { Radijs, spinazie, erwten, } \\
\text { bonen }\end{array}$ & 59 & 8 & 7 & & & & $x$ & & & & & & & & & & $x$ & \\
\hline 6 & $\begin{array}{l}\text { Spruiten, witlof, boerenkool, } \\
\text { radijs }\end{array}$ & 62 & 4 & 3 & & & & & & & & & & & & & & & $x$ \\
\hline 7 & $\begin{array}{l}\text { Ui, andijvie, knolselderij, prei, } \\
\text { wortelen, witlof }\end{array}$ & 65 & 4 & 4 & & & & $x$ & & & $\times$ & & & & & $x$ & & & $\times$ \\
\hline 8 & $\begin{array}{l}\text { Aubergine, aardbei, } \\
\text { tuinbonen }\end{array}$ & 68 & 1 & 3 & & & & & & & & & $\times$ & & & & & & \\
\hline 9 & Aardappel & 71 & 15 & 5 & & & & & $x$ & $x$ & & & & & & & & $x$ & $x$ \\
\hline 10 & Augurk & 74 & 5 & 1 & & & & & & & & & & & & & & $x$ & $x$ \\
\hline 11 & Broccoli & 77 & 1 & - & & & & & & & & & & & & $x$ & & & \\
\hline 12 & Erwten & 79 & 3 & - & & & & & & $x$ & & & & & & & & & $\times$ \\
\hline 13 & Knolselderij & 82 & 6 & 2 & & & & & & & & & & & & $\times$ & & $\times$ & $x$ \\
\hline 14 & Kroot (rode biet) & 85 & 4 & 2 & & & & & & & & & & & & & & & $x$ \\
\hline 15 & Peen & 88 & 4 & 2 & & & & & & & & & & & & & & & $x$ \\
\hline 16 & Prei & 91 & 5 & 3 & & & & & & & & & & & & & & $x$ & \\
\hline 17 & Radijs & 94 & 5 & 3 & & & & & & & & & & & & $x$ & & & $\times$ \\
\hline 18 & Groene Savooiekool & 97 & 4 & 2 & & & & & & & & & & & & & & & $x$ \\
\hline 19 & Spinazie & 100 & 4 & 2 & & & & & & & & & & & & $\times$ & & & $\times$ \\
\hline 20 & Suikerbieten & 103 & 9 & 8 & & & & & & & & & & & & & & $\times$ & $x$ \\
\hline 21 & Uien & 106 & 6 & 2 & & & & & & & & & & & & $\times$ & & $\times$ & $\times$ \\
\hline 22 & Wortel & 109 & 6 & 2 & & & & & & & & & & & & $x$ & & $x$ & $x$ \\
\hline 23 & Sierteelt & 112 & 8 & 8 & & & & & & $\times$ & $\times$ & & & & & & & $x$ & \\
\hline 24 & Amaryllis, Chrysant & 115 & 4 & 8 & & & & & & & & & $x$ & & & & $x$ & & \\
\hline 25 & Bollentelers Noord-Holland & 118 & 1 & - & & & & & & & & & & & & & & & \\
\hline 26 & Boomkwekerij & 120 & 4 & 2 & & & & & & $x$ & & & & & & & $x$ & & \\
\hline 27 & Tulpen & 123 & 6 & 1 & & & & & & & & & $\times$ & & $\times$ & $x$ & & & \\
\hline 28 & Fruitbomen & 126 & 7 & 9 & $x$ & $\times$ & & & & & & & & & & & & & $\times$ \\
\hline 29 & $\begin{array}{l}\text { Paprika, tomaat, } \\
\text { komkommer, sla }\end{array}$ & 129 & 6 & 7 & & $x$ & & & & & & & $x$ & & & & $x$ & & \\
\hline 30 & Komkommer & 132 & 5 & 1 & & & & & $x$ & $\times$ & $\times$ & & $\times$ & & & & & & \\
\hline 31 & Paprika & 135 & 2 & 1 & & & & & & $\times$ & & & $\times$ & & & & & & \\
\hline 32 & Kropsla, IJsbergsla & 138 & 2 & - & & & & & & & & & & & & $x$ & & $x$ & \\
\hline 33 & Sla & 141 & 5 & - & & & & $\times$ & & & & & & & & & & & $x$ \\
\hline 34 & Tomaten & 144 & 4 & 2 & & & & & $\times$ & $x$ & & & & & & & & & \\
\hline 35 & Substraatteelt & 147 & 2 & 8 & & & & & & & & & $x$ & & & $x$ & & & \\
\hline
\end{tabular}


Verwarrend is wellicht dat sommige gewassen/teelten in Tabel 3 op meerdere plekken worden genoemd: individueel, en/of geclusterd in één of meer gewasgroepen. De reden hiervan is dat deze gewassen/teelten in de hier opgesomde samenstellingen door diverse onderzoekers in verschillende projecten zijn beschreven.

De variatie in het aantal nieuwe en geciteerde zouttolerantiedrempels wordt voor kennisgeving aangenomen. Er zijn gewassen waarvoor veel nieuwe drempels werden geïntroduceerd, zoals aardappel (15), maar het aantal is doorgaans aanzienlijk lager; gemiddeld ruim vijf keer. Nieuwe drempels werden gemiddeld genomen ruim driemaal geciteerd, maar ook hier zijn koplopers, bijvoorbeeld fruitbomen en kapitaalintensieve teelten. Bij een klein aantal gewassen werden gepubliceerde drempels in latere publicaties nooit geciteerd. Tabel 4 geeft de onder- en bovengrenzen van de waardenintervallen van alle gerapporteerde zouttolerantiedrempels die in deze bureaustudie boven tafel zijn gekomen.

Tabel 4 Onder- en bovengrenzen van de wardenintervallen van gerapporteerde zouttolerantiedrempels van 35 geïdentificeerde gewassen en gewasgroepen, gemeten in beregeningswater. Bij gewas(groep)en 3, 8, 11 en 25 was slechts sprake van één gerapporteerde waarneming.

\begin{tabular}{|c|c|c|c|}
\hline \multirow{2}{*}{ No } & \multirow{2}{*}{ Gewas(groep) } & \multicolumn{2}{|c|}{$\begin{array}{c}\text { Waardeninterval } \\
\text { zouttolerantiedrempel }\end{array}$} \\
\hline & & $\begin{array}{l}\text { Ondergrens } \\
\left.\mathrm{Cl}^{-} \text {( } \mathrm{mg} / \mathrm{I}\right)\end{array}$ & $\begin{array}{l}\text { Bovengrens } \\
\mathrm{Cl}^{-} \text {(mg/I) }\end{array}$ \\
\hline 1 & Grasland & 600 & 10000 \\
\hline 2 & Tarwe, gerst & 600 & 10000 \\
\hline 4 & Snijmais & 200 & 1300 \\
\hline 5 & Radijs, spinazie, erwten, bonen & 100 & 600 \\
\hline 6 & Spruiten, witlof, boerenkool, radijs & 900 & 1200 \\
\hline 7 & Ui, andijvie, knolselderij, prei, wortelen, witlof & 300 & 2300 \\
\hline 11 & Broccoli & \multicolumn{2}{|c|}{600} \\
\hline 12 & Erwten & 340 & 1100 \\
\hline 13 & Knolselderij & 325 & 1070 \\
\hline 14 & Kroot (rode biet) & 900 & 1200 \\
\hline 15 & Peen & 600 & 1070 \\
\hline 16 & Prei & 600 & 1070 \\
\hline 17 & Radijs & 230 & 1200 \\
\hline 18 & Groene Savooiekool & 900 & 1200 \\
\hline 19 & Spinazie & 375 & 1200 \\
\hline 26 & Boomkwekerij & 150 & 300 \\
\hline 27 & Tulpen & 200 & 1500 \\
\hline 28 & Fruitbomen & 150 & 1000 \\
\hline 29 & Paprika, tomaat, komkommer, sla & 142 & 500 \\
\hline 30 & Komkommer & 40 & 200 \\
\hline 31 & Paprika & 100 & 200 \\
\hline 32 & Kropsla, IJsbergsla & 225 & 375 \\
\hline 33 & Sla & 300 & 2500 \\
\hline 34 & Tomaten & 200 & 500 \\
\hline 35 & Substraatteelt & 25 & 50 \\
\hline
\end{tabular}

De waardenintervallen (minimum-maximum) van de gerapporteerde zouttolerantiedrempels (Tabel 4) zijn grafisch weergegeven in Figuur 15. 


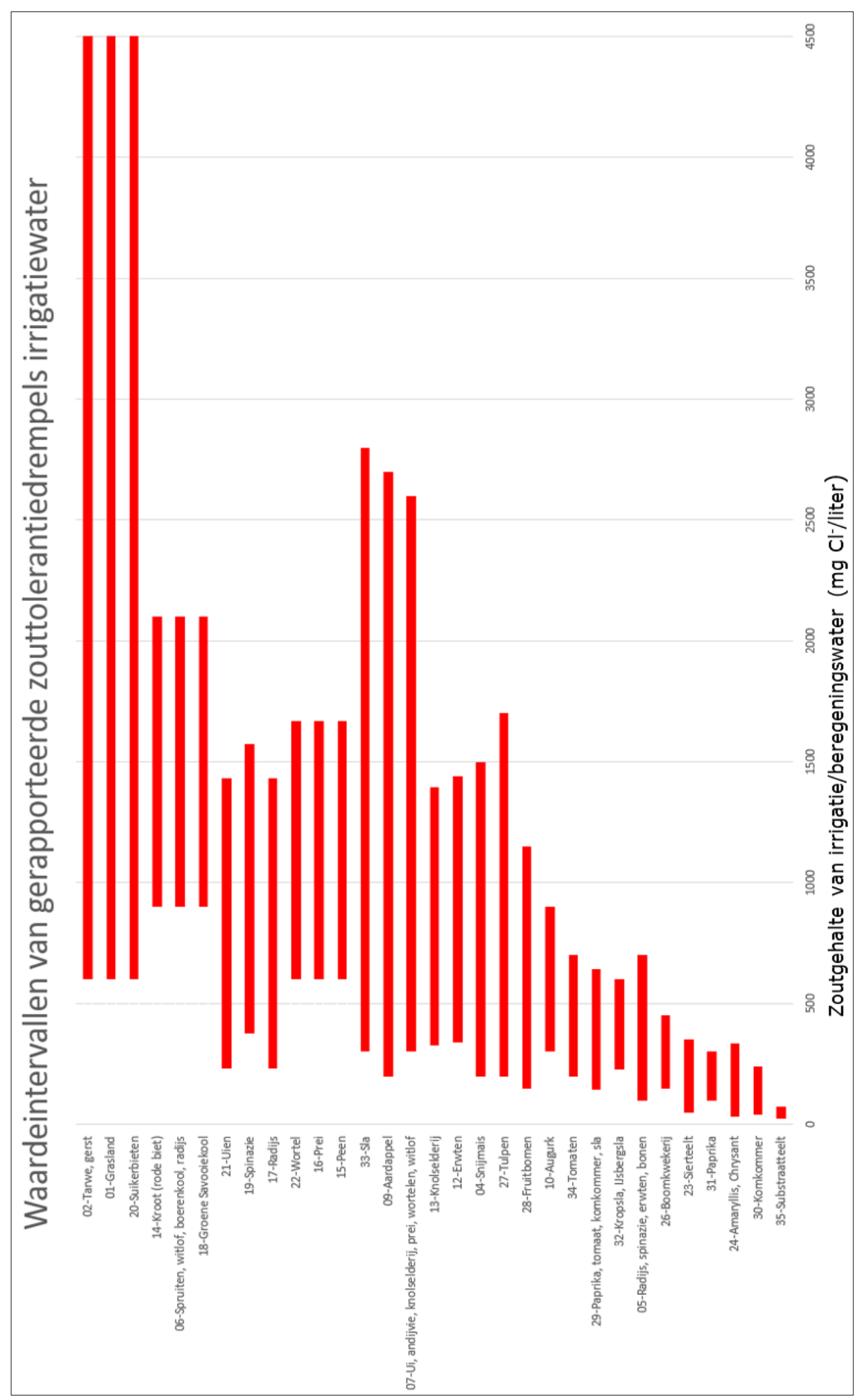

Figuur 15 Grafische weergave, per gewas(groep), van de waardenintervallen van gerapporteerde zouttolerantiedrempels van irrigatiewater voor landbouwgewassen en -gewasgroepen, in neerwaartse richting gerangschikt naar afnemende gemiddelde waarde. De bovengrenzen van de bovenste drie intervallen (tarwe/gerst, grasland en suikerbieten), respectievelijk 10000, 10000 en $5000 \mathrm{mg}$ $\mathrm{Cl}^{-}$/liter, overschrijden de hier gebruikte horizontale schaal. De gewassen klaver (3) en broccoli (11), de categorie 'bollentelers Noord-Holland' (25) en de gewasgroep aubergine-aardbei-tuinbonen (8), waarvoor slechts één zouttolerantiedrempel werd gespecificeerd (zie Tabel 4) zijn niet weergegeven. 
De in Figuur 15 horizontaal weergegeven intervallen worden begrensd door de extreme waarden: de hoogste en de laagste gerapporteerde zouttolerantiedrempel. De intervalbreedte is variabel, kleiner bij kapitaalintensieve teelten, en in veel gevallen aanzienlijk.

\subsection{Betrouwbaarheidsintervallen van drempelwaarden}

Hoewel inzichtelijk, geven de waardenintervallen geen informatie over de verdeling (de 'spreiding') van de erbinnen gelegen gerapporteerde zouttolerantiedrempels (aantallen, waarden). Zijn de gerapporteerde waarden uniform over het interval verdeeld, of is er sprake van een scheve verdeling, met de nadruk op lagere of hogere waarden?

Tijdens de inventarisatie ontstond daarom al snel de vraag hoe de gerapporteerde drempelwaarden op een eenduidige en verifieerbare manier voor interpretatie en discussie hanteerbaar zouden kunnen worden gemaakt. Voor elke gewas/gewasgroep willen we immers weten: wat is, gegeven het waardeninterval, de meest waarschijnlijke drempelwaarde, en met welke zekerheid kunnen we die op grond van de bestaande gegevens vaststellen? Vertaald in statistisch jargon: wat zijn de verwachtingswaarde en de spreiding van de zouttolerantiedrempels binnen het bewuste interval?

Geconcludeerd werd dat een simpele statistische bewerking van de gegevens zinvol zou kunnen zijn. Van de gerapporteerde zouttolerantiedrempels is daarom, per gewas(groep), een standaardnormale kansverdeling bepaald. Strikt genomen is het aantal waarnemingen van de zouttolerantiedrempel in alle gevallen (veel) te gering om hier een statistische verdeling aan te kunnen/mogen koppelen. De keuze om dit toch te doen is echter ingegeven door het feit dat vasthouden aan één 'gemiddelde' drempelwaarde, op grond van de informatie die tijdens deze bureaustudie boven tafel is gehaald, niet voor de hand ligt (Bakel en Stuyt, 2011). We moeten het doen met de gegevens die we hebben.

Met uitzondering van klaver (3), aubergine-aardbei-tuinbonen (8), broccoli (11) en 'bollentelers Noord-Holland' (25), waarvoor slechts één zouttolerantiedrempel werd gespecificeerd, zijn aan de gerapporteerde drempelwaarden van de zouttolerantie per gewas(groep) normale kansverdelingen 'gefit', om de onzekerheid van de drempelwaarden te kwantificeren. Gekozen is voor een standaardnormale- of Gaussverdeling. Deze keuze lijkt arbitrair, maar veel natuurlijke verschijnselen zijn benaderend te beschrijven met behulp van een standaardnormale verdeling, waarin de geïnventariseerde getallen symmetrisch geconcentreerd zijn rond het gemiddelde, en de afwijkingen van het gemiddelde steeds minder waarschijnlijker worden naarmate ze groter zijn. We berekenen de gemiddelde drempelwaarde $\mu$, ook wel de meest waarschijnlijke drempelwaarde genoemd.

De factoren plantleeftijd tijdens de blootstelling aan zout, duur van de blootstelling, zoutconcentratie in de wortelzone, bodemkarakteristieken, ontwateringstoestand, klimatologische omstandigheden en dergelijke, waarvan aannemelijk is dat zij de waarde van een gemeten zouttolerantiedrempel beïnvloeden ${ }^{10}$ kunnen weliswaar met zekerheid worden geïdentificeerd, maar de kennis ontbreekt op dit moment om deze invloed concreet en te vertalen in getalsmatige effecten op gemeten drempelwaarden. We kunnen de geconstateerde spreiding echter niet negeren. Voorgesteld wordt daarom om de per gewas(groep) gerapporteerde zouttolerantiedrempels, naast de gemiddelde drempelwaarde $\mu$, ook te karakteriseren door het $40 \%$ betrouwbaarheidsinterval van de 'gefitte' standaardnormale verdeling, waarin de spreiding in de gerapporteerde drempelwaarden is verdisconteerd. Hoe groter de spreiding, des te groter is de onzekerheid rond de betreffende drempel.

Met de introductie van een betrouwbaarheidsinterval leggen we een koppeling met de (statistische) spreiding van de gerapporteerde zouttolerantiedrempels. Een interval dat alleen gemarkeerd wordt door de extreme gerapporteerde waarden biedt die garantie niet, met het risico op misinterpretatie.

\footnotetext{
${ }^{10}$ Dit feit werd al langgeleden onderkend, getuige een citaat uit Thomas (1973): 'Plant salt tolerance data should only serve as a guide to relative tolerances among crops. Absolute tolerances vary depending upon climate, soil conditions and cultural practices. In gypsiferous soils, plants will tolerate about $2 \mathrm{dS} / \mathrm{m}$ higher soil salinity (ECe) than indicated but the water salinity (ECW) will remain the same as shown in this table'.
} 
De interpretatie van een $40 \%$ betrouwbaarheidsinterval is dat - op grond van de in deze bureaustudie verzamelde gegevens - de kans dat een drempelwaarde groter is dan de ondergrens van het betrouwbaarheidsinterval maar tegelijkertijd kleiner dan de bovengrens, $40 \%$ is. Getalsmatig gezien is de keuze voor een $40 \%$ betrouwbaarheidsinterval arbitrair en intuïtief, maar niet kritisch. Als we een kleiner (groter) percentage kiezen leidt dit tot smallere (bredere) intervallen, maar onze interpretatie blijft kwalitatief en onveranderd.

Het resultaat van deze stap is dat we voor elk van de 31 gewassen en gewasgroepen nu beschikken over een eenduidig gedefinieerde zouttolerantiedrempel die gebaseerd is op alle gerapporteerde, bruikbare meetresultaten die gedurende vele decennia in ons land zijn gedaan; er zit veel kennis en expertise in.

Ongeacht het gekozen percentage van $40 \%$ is een betrouwbaarheidsinterval omgekeerd evenredig met de wortel van het aantal gerapporteerde nieuwe drempels $n$, te weten $n^{-1 / 2}$. Dit betekent dat als er meer zouttolerantiedrempels van een bepaalde gewas(groep) zijn gerapporteerd, dit automatisch leidt tot een 'smaller' interval. Meer gerapporteerde drempelwaarden betekent dus een betrouwbaarder schatting van de drempelwaarde.

De parameters van de normale verdelingen, te weten het gemiddelde $(\mu)$ en standaardafwijking $(\sigma)$, werden berekend in de in dit project ontwikkelde Excel database; het $40 \%$ betrouwbaarheidsinterval van de zouttolerantiedrempel met een webapplicatie ${ }^{11}$.

De hierboven beschreven bewerking leidt, bijvoorbeeld voor de gewasgroep 29 (paprika, tomaat, komkommer, sla), via $\mu=308$ en $\sigma=153$, tot een $40 \%$ betrouwbaarheidsinterval van $225-400 \mathrm{mg} \mathrm{Cl}^{-} / \mathrm{l}$; zie Figuur 16.

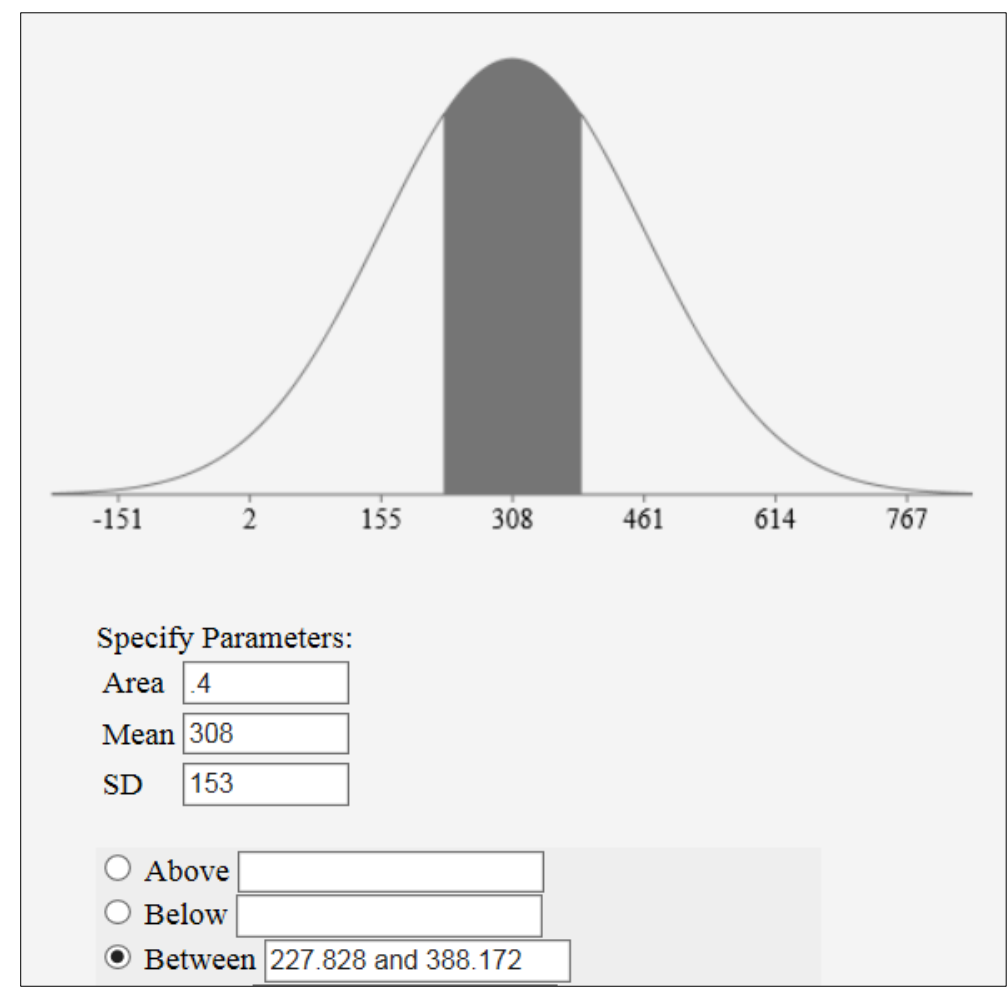

Figuur 16 Berekening van het 40\% betrouwbaarheidsinterval van de zouttolerantiedrempel van gewasgroep 29: paprika, tomaat, komkommer, sla. De gemiddeld gerapporteerde zouttolerantiedrempel $\mu=308 \mathrm{mg} \mathrm{Cl} / /$ en de standaardafwijking $\sigma=153 \mathrm{Cl}^{-} / \mathrm{l}$. Het $40 \%$ betrouwbaarheidsinterval, grijs gemarkeerd, ligt tussen 227,8 en 388,2 $\mathrm{mg} \mathrm{Cl}^{-} / \mathrm{l}$, afgerond tussen 225 en $400 \mathrm{mg} \mathrm{Cl} / \mathrm{l}$. De berekening werd uitgevoerd met een webapplicatie $1^{11}$.

\footnotetext{
${ }^{11}$ http://onlinestatbook.com/2/calculators/inverse_normal_dist.html
} 
De zoutschade die een gewas(groep) kan ondervinden wordt niet alleen gekarakteriseerd door een zoutschadedrempel, maar ook door de zoutschadegevoeligheid, die gedefinieerd is als de procentuele opbrengstderving (\%), veroorzaakt door zoutschade boven de zoutschadedrempel, en weergegeven als de helling in Figuur 4 (pagina 19) en als de hellingshoek $E C_{\text {slope }}$ in Figuur 9 (pagina 24). De hier uitgevoerde bureaustudie heeft over zoutschadegevoeligheden geen bruikbare informatie opgeleverd. Daarom is besloten om terug te grijpen op een door Bakel en Stuyt (2011) uitgevoerde analyse. De in Tabel 5 gespecificeerde zoutschadegevoeligheden zijn schattingen die zij bij gebrek aan gegevens van veldexperimenten op grond van een enkele aannames hebben gemaakt. Een belangrijke aanname bij deze schattingen was dat de gemiddelde chlorideconcentratie in de wortelzone tweemaal zo hoog is als de chlorideconcentratie in beregeningswater.

Tabel 5 Per zoutgevoeligheidsklasse afgeleide parameters voor de zoutschadefunctie, geldig voor beregeningswater als een indikkingsfactor 2 tussen het beregeningswater en de wortelzone wordt gebruikt (Bron: Bakel en Stuyt, 2011).

\begin{tabular}{|c|c|c|}
\hline Zoutgevoeligheidsklasse & $\begin{array}{r}\text { Zoutschadedrempel } \\
(\mathrm{mg} \mathrm{Cl} / \mathrm{I})\end{array}$ & $\begin{array}{c}\text { Zoutschadegevoeligheid } \\
\left(\% \text { opbrengstdaling } / \mathbf{1 0 0} \text { mg } \mathrm{Cl}^{-} / \mathrm{I}\right)\end{array}$ \\
\hline Gevoelig & 300 & 8 \\
\hline Matig gevoelig & 600 & 4 \\
\hline Matig tolerant & 1200 & 2 \\
\hline Tolerant & 2400 & 1 \\
\hline
\end{tabular}

Een grotere standaardafwijking $(\sigma)$ van gerapporteerde waarden van een zoutschadedrempel betekent automatisch een groter betrouwbaarheidsinterval (Tabel 6). Die van bijvoorbeeld aardappel (No. 9) is met $700 \mathrm{mg} \mathrm{Cl}^{-} / /$vrij breed, en die van paprika (No. 31) slechts $50 \mathrm{mg} \mathrm{Cl} / /$. Verondersteld wordt dat de afstand tussen de onder- en de bovengrens indicatief is voor de relevantie en de bruikbaarheid.

In Tabel 6 zijn de resultaten van deze bewerkingen samengevat. Deze tabel geeft voor 35 gewassen en gewasgroepen informatie over: het aantal gepubliceerde zouttolerantiedrempels, het aantal keren dat een zouttolerantiedrempel in latere publicaties is geciteerd, de parameters $\mu$ (gemiddelde) en $\sigma$ (standaardafwijking) van de standaardnormale verdeling die op de beschikbare gegevens is 'gefit', het betrouwbaarheidsinterval van 31 gewassen en gewasgroepen, een geschatte zoutschadegevoeligheid en een overzicht van de jaren waarin nieuwe drempelwaarden werden geïntroduceerd. 
Tabel 6 Overzichtstabel met het aantal gepubliceerde zouttolerantiedrempels, gemeten in beregeningswater, van 35 geïdentificeerde gewassen en gewasgroepen, het aantal keren dat een zouttolerantiedrempel in latere publicaties is geciteerd, de parameters $\mu$ (gemiddelde) en $\sigma$ (standaardafwijking) van de standaardnormale verdeling die op de beschikbare gegevens is 'gefit', de onder- en bovengrens en de bandbreedte van de $40 \%$ betrouwbaarheidsintervallen en de jaren waarin nieuwe drempelwaarden voor het chloridegehalte van beregeningswater werden geïntroduceerd. Bij gewas(groep)en 3, 8, 11 en 25 was slechts sprake van één gerapporteerde drempel. De zoutschadegevoeligheid (\% opbrengstdaling/100 $\mathrm{mg} \mathrm{Cl} / \mathrm{I}$ ) is geschat op grond van een indeling van gewassen en gewasgroepen in vier zoutgevoeligheidsklassen (Bakel en Stuyt, 2011).

\begin{tabular}{|c|c|c|c|c|c|c|c|c|c|c|c|c|c|c|c|c|c|c|c|c|c|c|c|c|}
\hline \multirow[b]{2}{*}{ No } & \multirow[b]{2}{*}{ Gewas(groep) } & \multicolumn{2}{|c|}{$\begin{array}{c}\text { Aantal } \\
\text { drempels }\end{array}$} & \multicolumn{2}{|c|}{$\begin{array}{l}\text { Parameters van } \\
\text { 'gefitte' normale } \\
\text { kansverdeling }\end{array}$} & \multicolumn{3}{|c|}{$\begin{array}{c}\text { Grenzen } 40 \% \\
\text { betrouwbaarheids- } \\
\text { interval }\end{array}$} & \multirow{2}{*}{ 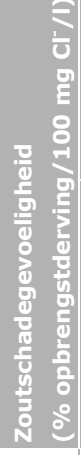 } & \multicolumn{15}{|c|}{$\begin{array}{l}\text { Introductiejaar nieuwe } \\
\text { drempelwaarde( } n \text { ) } \\
\text { (bij benadering) }\end{array}$} \\
\hline & & $\frac{3}{2}$ & 율 & 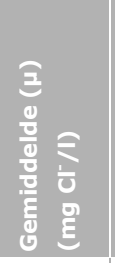 & 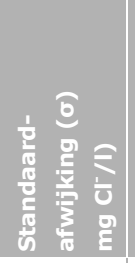 & 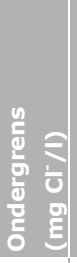 & $\begin{array}{l}\frac{y}{5} \\
\frac{5}{5} \\
\frac{1}{5} \\
\frac{5}{0} \\
0 \\
0 \\
0 \\
0\end{array}$ & 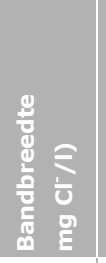 & & \begin{tabular}{|l}
$\mid$ \\
of \\
के \\
\end{tabular} & 윰 & 是 & :을 & 우 & $\stackrel{0}{\circ}$ & กิ & \begin{tabular}{l|}
$\circ$ \\
. \\
\%े
\end{tabular} & 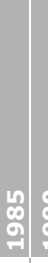 & $\begin{array}{l}8 \\
8 \\
2\end{array}$ & in & : & ำ & 융 & 둥 \\
\hline 1 & Grasland & 10 & 5 & 2055 & 2711 & 650 & 3475 & 2825 & 1 & & $x$ & & & & $x$ & & & & & $\times$ & & & & \\
\hline 2 & Tarwe, gerst & 11 & 6 & 2626 & 2796 & 1150 & 4100 & 2950 & 1 & & $x$ & & & & $x$ & & & & & & & & & $x$ \\
\hline 3 & Klaver (Luzerne) & 1 & - & 10000 & - & & - & - & 1 & & $x$ & & & & & & & & & & & & & \\
\hline 4 & Snijmais & 6 & 2 & 498 & 371 & 275 & 700 & 400 & 4 & & & & & & & & & & & & & & $\times$ & \\
\hline 5 & $\begin{array}{l}\text { Radijs, spinazie, erwten, } \\
\text { bonen }\end{array}$ & 8 & 7 & 267 & 166 & 180 & 350 & 170 & 8 & & & & $x$ & & & & & & & & & & $x$ & \\
\hline 6 & $\begin{array}{l}\text { Spruiten, witlof, } \\
\text { boerenkool, radijs }\end{array}$ & 4 & 3 & 1093 & 123 & 1030 & 1150 & 120 & 3 & & & & & & & & & & & & & & & $x$ \\
\hline 7 & $\begin{array}{l}\text { Ui, andijvie, knolselderij, } \\
\text { prei, wortelen, witlof }\end{array}$ & 4 & 4 & 963 & 817 & 550 & 1140 & 590 & 3 & & & & $x$ & & & $x$ & & & & & $\times$ & & & $x$ \\
\hline 8 & $\begin{array}{l}\text { Aubergine, aardbei, } \\
\text { tuinbonen }\end{array}$ & 1 & 3 & 300 & - & - & - & - & 8 & & & & & & & & & $\times$ & & & & & & \\
\hline 9 & Aardappel & 15 & 5 & 838 & 668 & 500 & 1200 & 700 & 3 & & & & & $x$ & $x$ & & & & & & & & $\times$ & $x$ \\
\hline 10 & Augurk & 5 & 1 & 423 & 111 & 350 & 475 & 125 & 8 & & & & & & & & & & & & & & $\times$ & $x$ \\
\hline 11 & Broccoli & 1 & - & 600 & - & - & - & - & 4 & & & & & & & & & & & & $\times$ & & & \\
\hline 12 & Erwten & 3 & - & 647 & 327 & 475 & 825 & 350 & 4 & & & & & & $x$ & & & & & & & & & $x$ \\
\hline 13 & Knolselderij & 6 & 2 & 799 & 258 & 675 & 950 & 275 & 3 & & & & & & & & & & & & $x$ & & $\times$ & $x$ \\
\hline 14 & Kroot (rode biet) & 4 & 2 & 1093 & 123 & 1050 & 1150 & 100 & 3 & & & & & & & & & & & & & & & $x$ \\
\hline 15 & Peen & 4 & 2 & 868 & 169 & 800 & 950 & 150 & 3 & & & & & & & & & & & & & & & $x$ \\
\hline 16 & Prei & 5 & 3 & 894 & 160 & 800 & 975 & 175 & 3 & & & & & & & & & & & & & & $x$ & \\
\hline 17 & Radijs & 5 & 3 & 920 & 362 & 725 & 1100 & 375 & 3 & & & & & & & & & & & & $\times$ & & & $x$ \\
\hline 18 & Groene Savooiekool & 4 & 2 & 1093 & 123 & 1025 & 1150 & 125 & 3 & & & & & & & & & & & & & & & $x$ \\
\hline 19 & Spinazie & 4 & 2 & 919 & 337 & 750 & 1100 & 350 & 3 & & & & & & & & & & & & $\times$ & & & $x$ \\
\hline 20 & Suikerbieten & 9 & 8 & 1478 & 817 & 1050 & 1900 & 850 & 2 & & & & & & & & & & & & & & $\times$ & $x$ \\
\hline 21 & Uien & 6 & 2 & 867 & 351 & 875 & 1050 & 175 & 6 & & & & & & & & & & & & $\times$ & & $\times$ & $x$ \\
\hline 22 & Wortel & 6 & 2 & 903 & 148 & 825 & 1000 & 175 & 6 & & & & & & & & & & & & $x$ & & $\times$ & $x$ \\
\hline 23 & Sierteelt & 11 & 8 & 161 & 82 & 100 & 200 & 100 & 8 & & & & & & $x$ & $x$ & & & & & & & $x$ & \\
\hline 24 & Amaryllis, Chrysant & 4 & 8 & 106 & 112 & 50 & 175 & 125 & 8 & & & & & & & & & $x$ & & & & $\times$ & & \\
\hline 25 & Bollentelers Noord-Holland & 1 & - & 200 & - & - & - & - & 8 & & & & & & & & & & & & & & & \\
\hline 26 & Boomkwekerij & 3 & 2 & 233 & 62 & 200 & 275 & 75 & 8 & & & & & & $x$ & & & & & & & $\times$ & & \\
\hline 27 & Tulpen & 4 & 1 & 475 & 468 & 225 & 725 & 500 & 8 & & & & & & & & & $x$ & & $\times \quad \times$ & $x$ & & & \\
\hline 28 & Fruitbomen & 6 & 9 & 465 & 381 & 275 & 675 & 400 & 8 & $x$ & $x$ & & & & & & & & & & & & & $\times$ \\
\hline 29 & $\begin{array}{l}\text { Paprika, tomaat, } \\
\text { komkommer, sla }\end{array}$ & 6 & 7 & 308 & 153 & 225 & 400 & 175 & 8 & & $x$ & & & & & & & $x$ & & & & $\times$ & & \\
\hline 30 & Komkommer & 5 & 1 & 113 & 72 & 75 & 150 & 75 & 8 & & & & & $x$ & $x$ & $x$ & & $\times$ & & & & & & \\
\hline 31 & Paprika & 2 & 1 & 150 & 50 & 125 & 175 & 50 & 8 & & & & & & $x$ & & & $x$ & & & & & & \\
\hline 32 & Kropsla, IJsbergsla & 2 & - & 300 & 75 & 275 & 350 & 75 & 8 & & & & & & & & & & & & $x$ & & $\times$ & \\
\hline 33 & Sla & 5 & - & 848 & 833 & 425 & 1300 & 875 & 4 & & & & $x$ & & & & & & & & & & & $x$ \\
\hline 34 & Tomaten & 4 & 2 & 338 & 119 & 275 & 400 & 125 & 8 & & & & & $x$ & $x$ & & & & & & & & & \\
\hline 35 & Substraatteelt & 2 & 8 & 38 & 13 & 30 & 45 & 15 & 8 & & & & & & & & & $x$ & & & $\times$ & & & \\
\hline
\end{tabular}


Eenzelfde spreiding in gerapporteerde drempelwaarden weegt bij gewassen en gewasgroepen met lage zouttoleranties zwaarder dan bij gewas(groepen) met hoge toleranties. Daarom is de afstand tussen de onder- en bovengrens van de $40 \%$ betrouwbaarheidsintervallen ook berekend als percentage van het gemiddelde volgens de betrekking (bovengrens-ondergrens) $/ \mu * 100 \%$. Het resultaat van deze rekenstap is 31 'bandbreedtes'. De bandbreedte varieert van 11 tot $137 \%$ van de gemiddelde waarde, is vervolgens (arbitrair) geclassificeerd in vijf stappen en geeft aldus een beeld van de betrouwbaarheid van de waarde van een gerapporteerde zouttolerantiedrempel; zie Tabel 7.

Tabel $7 \quad 40 \%$ betrouwbaarheidsintervallen van 31 gewassen en gewasgroepen, berekend als percentage van de gemiddelde zouttolerantiedrempel $(\mu)$. De bandbreedte varieert van 11 tot $137 \%$ van dit gemiddelde, is (arbitrair) geclassificeerd in vijf categorieën en geeft daarmee een beeld van de relevantie en dus de bruikbaarheid van de gerapporteerde drempel; ' 5 ' = bruikbaar; '1' = weinig bruikbaar. Een kleine bandbreedte betekent dat de gerapporteerde zouttolerantiedrempels in het irrigatiewater qua waarde niet veel uiteenlopen: dit suggereert een grotere bruikbaarheid/relevantie van de bewuste drempel dan een grote bandbreedte.

\begin{tabular}{|c|c|c|c|}
\hline No. & Gewas(groep) & $\begin{array}{l}\text { Betrouwbaarheidsinterval } \\
\text { drempelwaarde ten opzichte } \\
\text { van gemiddelde waarde (\%) }\end{array}$ & $\begin{array}{c}\text { Indicatieve } \\
\text { betrouwbaarheid } \\
\text { zouttolerantiedrempel }\end{array}$ \\
\hline 6 & Spruiten, witlof, boerenkool, radijs & 11 & \multirow{3}{*}{5} \\
\hline 18 & Groene Savooiekool & 11 & \\
\hline 22 & Wortel & 19 & \\
\hline 16 & Prei & 20 & \multirow{6}{*}{4} \\
\hline 21 & Uien & 20 & \\
\hline 32 & Kropsla, IJsbergsla & 24 & \\
\hline 10 & Augurk & 30 & \\
\hline 34 & Tomaten & 37 & \\
\hline 19 & Spinazie & 38 & \\
\hline 35 & Substraatteelt & 40 & \multirow{5}{*}{3} \\
\hline 17 & Radijs & 41 & \\
\hline 12 & Erwten & 54 & \\
\hline 29 & Paprika, tomaat, komkommer, sla & 56 & \\
\hline 20 & Suikerbieten & 58 & \\
\hline 5 & Radijs, spinazie, erwten, bonen & 64 & 2 \\
\hline 33 & Sla & 101 & \multirow{5}{*}{1} \\
\hline 27 & Tulpen & 105 & \\
\hline 24 & Amaryllis, Chrysant & 111 & \\
\hline 2 & Tarwe, gerst & 112 & \\
\hline 1 & Grasland & 137 & \\
\hline
\end{tabular}

\subsection{Analyse en discussie}

Om het inzicht in de resultaten van deze inventarisatie te vergemakkelijken zijn de resultaten grafisch weergegeven. In Figuur 17 zijn de zouttolerantiedrempels in neerwaartse richting gerangschikt, in afnemende zouttolerantie. 


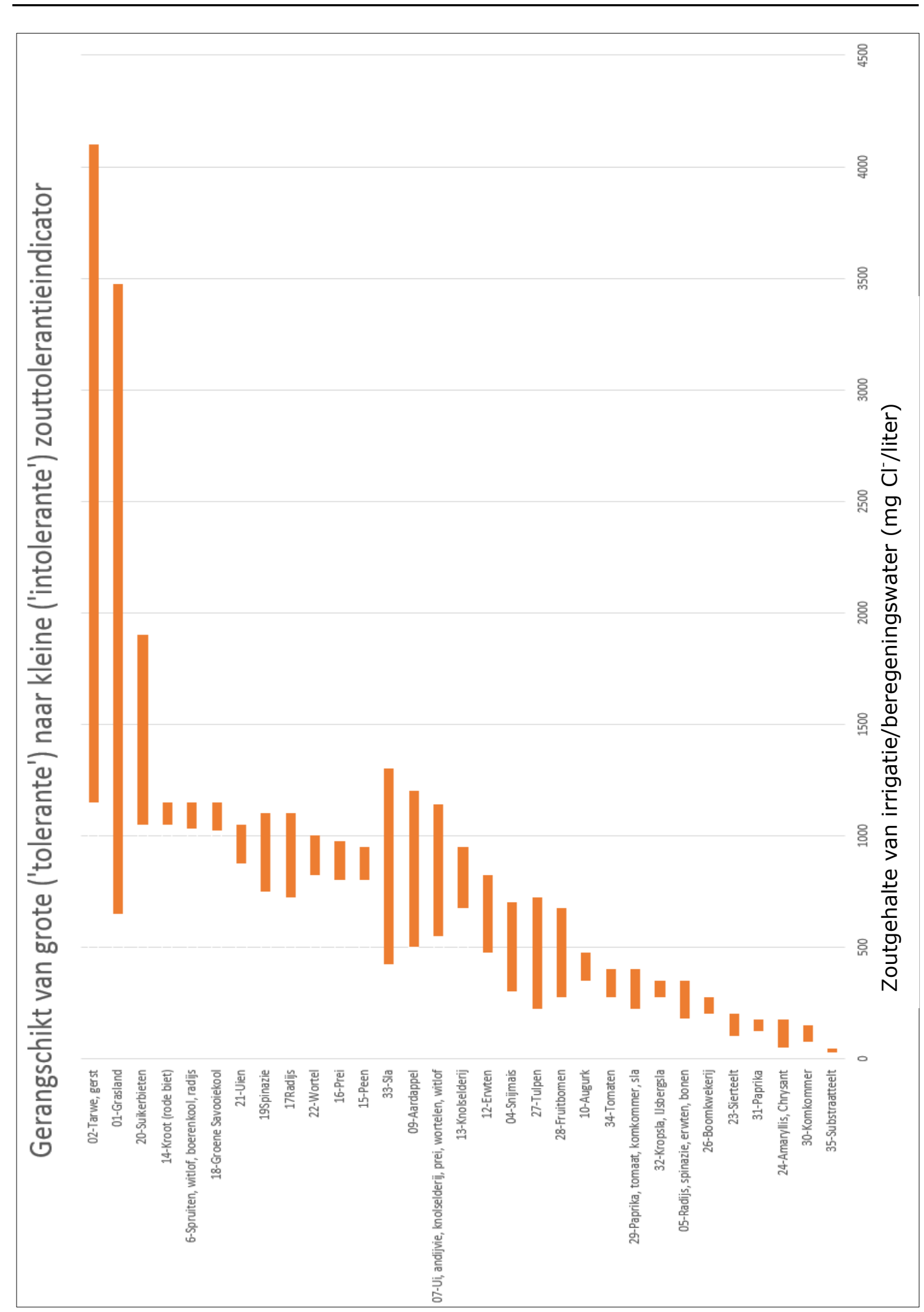

Figuur 17 Grafische weergave van de zouttolerantiedrempels met hun betrouwbaarheidsintervallen, in neerwaartse richting gerangschikt van 'groot' naar 'klein': hoe lager een gewas / de gewasgroep in deze figuur is weergegeven, des te kleiner is de zouttolerantiedrempel volgens de bestaande, geïnventariseerde gegevens. De gewassen klaver (3) en broccoli (11), de categorie 'bollentelers Noord-Holland' (25) en de gewasgroep aubergine-aardbei-tuinbonen (8), waarvoor slechts één zouttolerantiedrempel werd gespecificeerd (zie Tabel 4) zijn niet weergegeven. 
Uit Figuur 17 kan worden afgeleid dat er geen eenduidig verband bestaat tussen de hoogte van de gerapporteerde zouttoleranties en het waardeninterval (de 'bandbreedte'). De waardenintervallen van de grootste toleranties (granen, grasland, suikerbieten) zijn verreweg het grootst, maar de spreiding van de groep die loopt van 'sla' tot en met 'fruitbomen' is ook aanzienlijk. De bandbreedte houdt ongetwijfeld verband met een variëteit aan omstandigheden waaronder de tolerantie werd vastgesteld. Het is overigens opmerkelijk (en teleurstellend) dat over deze omstandigheden in de onderzochte rapportages weinig tot geen informatie wordt verstrekt. De onderste groep, met geringe toleranties, vertoont een kleine spreiding: een resultaat dat in lijn is met de verwachting omdat deze kapitaalintensieve gewassen onder strak geregisseerde omstandigheden worden geteeld.

De 'vervanging' van waardenintervallen van 31 reeksen gepubliceerde zouttolerantiedrempels die bepaald worden door gerapporteerde onder- en bovengrenzen door $40 \%$ betrouwbaarheidsintervallen leidt tot een classificatie met een sterker onderscheidend vermogen; zie Figuur 18. Deze verbeterde classificatie wordt veroorzaakt door het feit dat het waardeninterval van zoutschadedrempels wordt bepaald door de spreiding van de drempelwaarden en niet door onder- en bovengrenzen (de zogenaamde úitbijters'). 


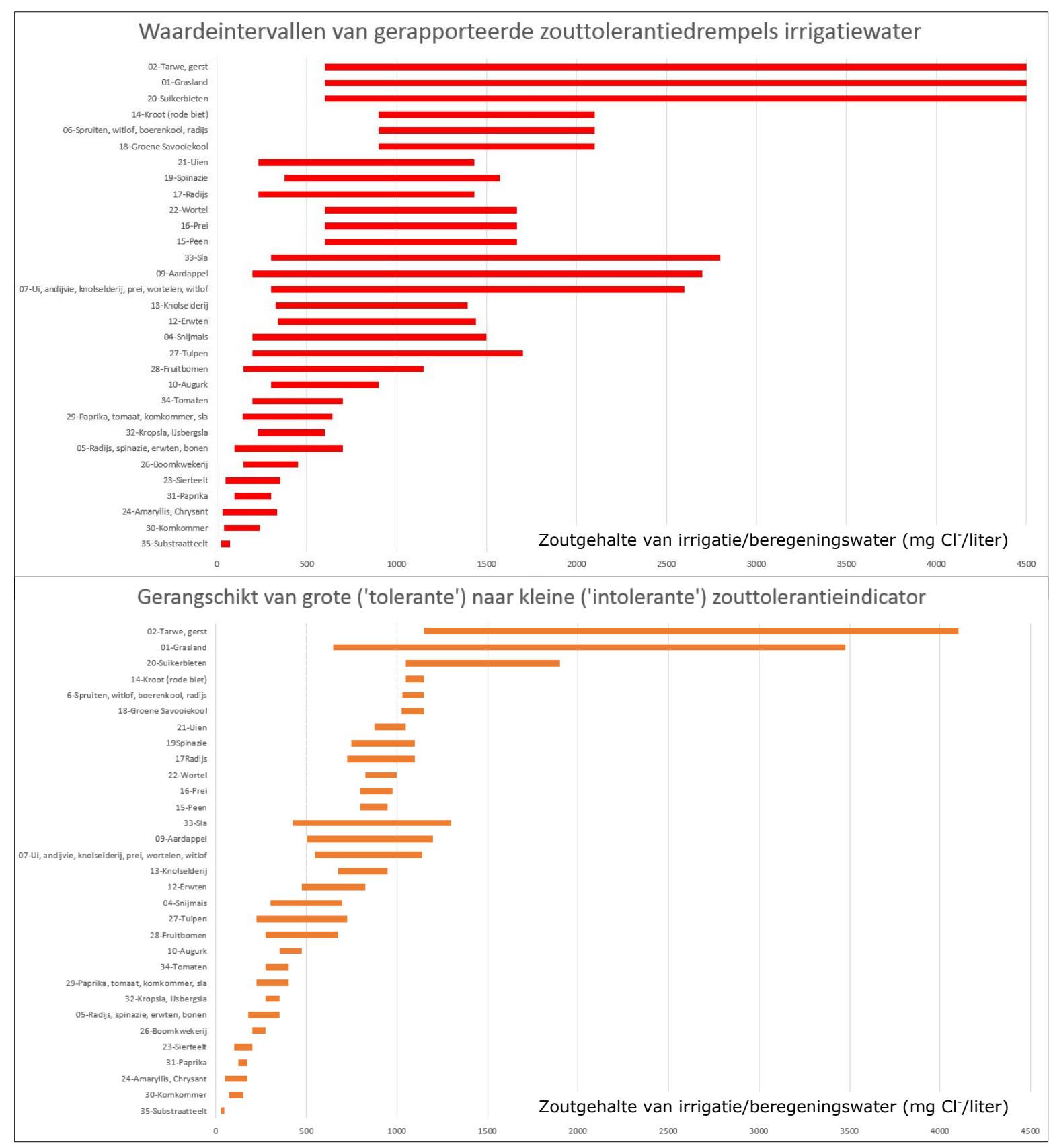

Figuur 18 Bovenste figuur (rood): Grafische weergave, per gewas(groep), van de waardenintervallen van gerapporteerde zouttolerantiedrempels van irrigatiewater voor landbouwgewassen en -gewasgroepen, in neerwaartse richting gerangschikt naar afnemende gemiddelde waarde. De bovengrenzen van de bovenste drie intervallen (tarwe/gerst, grasland en suikerbieten), respectievelijk 10000, 10000 en $5000 \mathrm{mg} \mathrm{Cl}$ /liter, overschrijden de hier gebruikte horizontale schaal.

Onderste figuur (oranje): Grafische weergave van de zouttolerantiedrempels, in neerwaartse richting gerangschikt van 'groot' naar 'klein': hoe lager een gewas(groep) in deze figuur is weergegeven, des te kleiner de zouttolerantiedrempel volgens de bestaande, geïnventariseerde gegevens. - De gewassen klaver (3) en broccoli (11), de categorie 'bollentelers Noord-Holland' (25) en de gewasgroep aubergine-aardbei-tuinbonen (8), waarvoor slechts één zouttolerantiedrempel werd gespecificeerd (zie Tabel 4) zijn niet weergegeven.

In Figuur 19 zijn de zouttoleranties zó gerangschikt dat zij in neerwaartse richting beter zijn gedefinieerd, omdat de spreiding van de toleranties (de breedte van het betrouwbaarheidsinterval) in deze richting afneemt. 


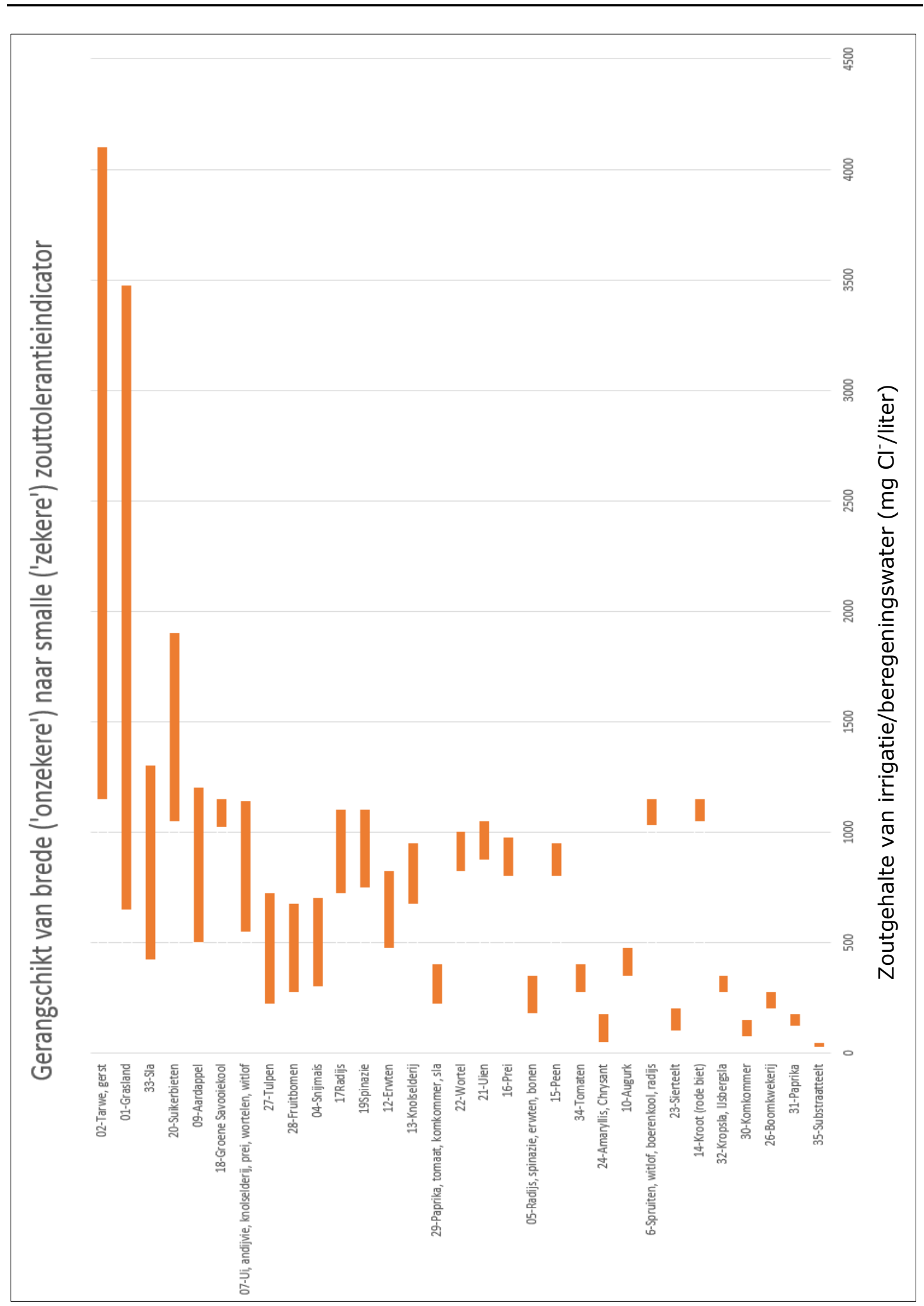

Figuur 19 Grafische weergave van de betrouwbaarheidsintervallen van de zouttolerantiedrempels, in neerwaartse richting gerangschikt van 'breed' naar 'smal': hoe lager een gewas / de gewasgroep in deze figuur is weergegeven, des te beter de zouttolerantie volgens de bestaande, geïnventariseerde gegevens is gedefinieerd. 
Uit Figuur 19 wordt duidelijk dat de zouttolerantie van landbouwgewassen en -gewasgroepen qua eenduidigheid/betrouwbaarheid grofweg in drie categorieën uiteenvalt. Afgaande op de geïnventariseerde gegevens is de tolerantie van een kleine groep (granen, grasland, suikerbieten) niet eenduidig. Daarnaast, 'onderaan', is er een groep kapitaalintensieve gewassen met een smal tolerantievenster; vooral tuinbouw onder glas, boom- en sierteelt e.d. Hiertussen zit een categorie die qua betrouwbaarheid het midden houdt tussen groepen 1 en 2 . De betrouwbaarheidsintervallen van de zouttolerantiedrempels van deze laatste groep is betrekkelijk smal: kennelijk wijzen alle gerapporteerde cijfers in min of meer dezelfde richting en dat is met het oog op het vaststellen van het voorzieningenniveau qua 'zout' goed nieuws. Opvallend is wel dat de bandbreedte met betrekking tot tulpen en fruitteelt (fruitbomen) vrij groot is.

De hier verkregen resultaten zijn goed bruikbaar voor de implementatie van 'zout' in 'Waterwijzer Landbouw', door introductie van aangepaste Maas-Hoffman zoutschadefuncties in het hier gebruikte modelinstrumentarium; zie de kolommen 'Gemiddelde $(\mu)^{\prime}$ en 'Zoutschadegevoeligheid' in Tabel 6 op pagina 37.

In Hoofdstuk 5 (vanaf pagina 47) is gedetailleerde informatie samengebracht omtrent alle 35 geïdentificeerde gewassen en gewasgroepen. 


\section{$4 \quad$ Conclusies en aanbevelingen}

1. Wat kunnen we uit de resultaten concluderen?

In Nederland is sinds de Tweede Wereldoorlog veel onderzoek verricht naar zouttolerantiedrempels van landbouwgewassen. Er is bijzonder veel gemeten, en gerekend met hiertoe ontwikkelde computerapplicaties. De interpretatie van de gerapporteerde bevindingen wordt echter bemoeilijkt door het feit dat de meetomstandigheden in verreweg de meeste gevallen slechts marginaal zijn beschreven en omdat de resultaten van computersimulaties nauwelijks zijn gevalideerd door middel van veldproeven. Van 31 van de 35 geïdentificeerde gewassen en gewasgroepen zijn, voor beregeningswater, meerdere zouttolerantiedrempels gerapporteerd. Deze vertonen qua waarde vaak een aanzienlijke spreiding ${ }^{12}$. De 'bandbreedte' van de zouttolerantiedrempels van een kleine groep gewassen (granen, grasland, suikerbieten) is zeer aanzienlijk. Daarnaast is er een groep kapitaalintensieve gewassen met een smal 'tolerantievenster'; vooral tuinbouw onder glas, boom- en sierteelt e.d. Hiertussen zit een categorie die qua bandbreedte het midden houdt tussen eerstgenoemde twee groepen; opvallend is dat die van tulpen en fruitteelt (fruitbomen) vrij groot is.

\section{Meest bepalende factoren}

Zouttolerantiedrempels in beregeningswater kunnen nooit met absolute zekerheid worden bepaald, want onnauwkeurigheden van meetinstrumenten en verstoringen in meetopstellingen introduceren onzekerheid. De spreiding in gemeten zouttolerantiedrempels moet echter vooral worden toegeschreven aan variabele factoren als:

(i) De zoutconcentratie in de wortelzone.

(ii) De bodemkarakteristieken.

(iii) De ontwateringstoestand.

(iv) De weersomstandigheden.

(v) De duur van de blootstelling aan zout.

(vi) De plantleeftijd tijdens de blootstelling aan zout.

(vii) Adaptatie van planten aan zoutstress.

(viii) Adaptatie van planten aan veranderende omgevingsfactoren.

\section{Wat is de maatschappelijke waarde van de nieuwe inzichten?}

De bestaande 'harde' zoetwaterdrempels in het oppervlaktewater vormen bruikbare 'stuurknoppen' in het operationele zoetwaterbeheer, want zij zijn eenduidig en verifieerbaar. De onzekerheid rond de drempelwaarden kan echter betekenen dat het voorzieningenniveau m.b.t. 'zout' (incidenteel) beter is dan vereist. De met deze studie verkregen inzichten voeden immers de veronderstelling dat drempelwaarden getalsmatig beter kunnen worden gespecificeerd zodra de hiervoor benodigde kennis beschikbaar is. Aansluitend kunnen de 'stuurknoppen' met betrekking tot 'zout' in het zoetwaterbeheer beter op de omstandigheden worden afgestemd. Helaas ontbreekt het op dit moment nog aan de 'harde getallen' die hiervoor nodig zijn.

\section{Kan het zouter of niet?}

Deze conclusie kan in algemene zin niet worden getrokken. De informatie die met deze rapportage beschikbaar komt heeft het inzicht vergroot dat het zoutgehalte van oppervlaktewater beter kan worden afgestemd op de (momentane) zouttolerantie van de gewassen die eruit beregend worden. De factoren die de drempelwaarde beïnvloeden zijn weliswaar geïdentificeerd, maar nog niet gekwantificeerd. En dat laatste is belangrijk, want deze factoren bepalen welk zoutgehalte op een bepaalde plek, op zeker moment bij een bepaald gewas nog acceptabel is. Stuyt en van Bakel hebben hiervan in hun 'Basic Survey Zout' in 2011 al kwalitatieve indicaties gegeven en deze visueel gepresenteerd; zie Figuur 20 (Stuyt et al., 2011).

\footnotetext{
${ }^{12}$ Spreiding = de mate waarin de waarden onderling verschillen.
} 


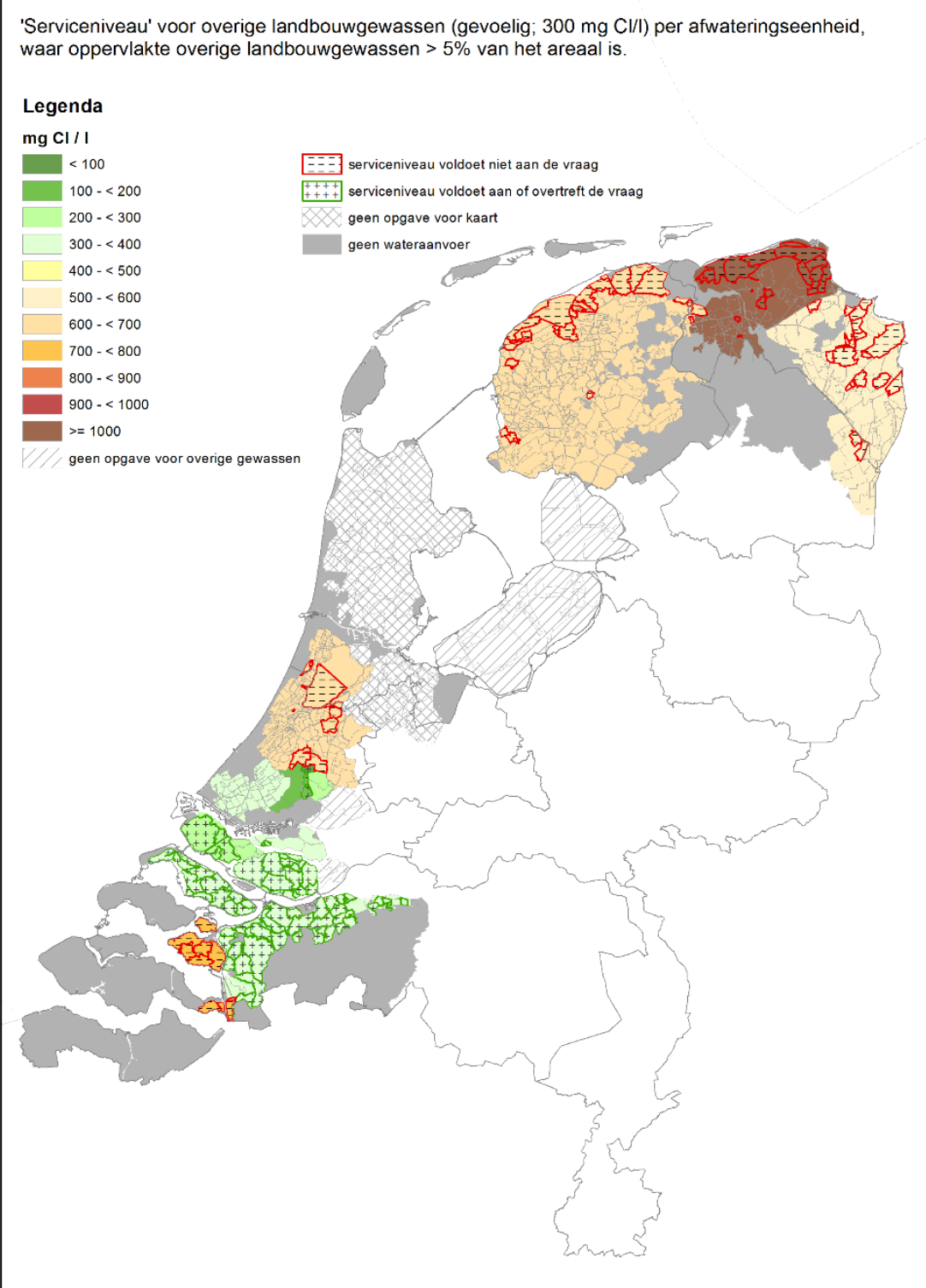

Figuur 20 Locaties waar een categorie zoutgevoelige landbouwgewassen zoutschade oploopt als het zoutgehalte van het aangevoerde oppervlaktewater waaruit beregend wordt een drempelwaarde van $300 \mathrm{mg} \mathrm{Cl} / \mathrm{l}$ overschrijdt (rood omlijnde regio's); bron: Stuyt et al. (2011). Dit 'serviceniveau' leidt echter niet overal tot problemen; op sommige locaties zou, gegeven de daar geteelde gewassen, met brakker water kunnen worden volstaan (groen omlijnde regio's). Deze kaart is gebaseerd op landsdekkende informatie over landbouwgewassen uit het Landelijk Grondgebruikbestand Nederland (LGN6), informatie over de door Stuyt et al. (2011) gepubliceerde zouttolerantie van gewassen, en de door waterschappen gespecificeerde chloridegehalten van oppervlaktewateren in hun beheersgebied.

\section{Implementatie in Waterwijzer Landbouw}

De hier verkregen resultaten zijn beperkt bruikbaar voor implementatie van 'zout' in 'Waterwijzer Landbouw' omdat bij de meeste experimenten de vertaalslag van de zoutconcentratie in het irrigatiewater naar de concentratie bodemvocht door een gebrek aan gegevens niet gemaakt kan worden. 


\section{Waar zitten de kennishiaten?}

In het kader van deze studie zijn onderstaande kennishiaten geïdentificeerd, met afnemende urgentie:

1. Het betrouwbaarheidsinterval van een zouttolerantiedrempel wordt gekenmerkt door een waardeninterval ('bandbreedte'). Het is nodig om de effecten van de op pagina 44 genoemde factoren getalsmatig en eenduidig aan dit waardeninterval te koppelen. Welke factoren werken drempelverlagend (i.c. grotere zouttolerantie), welke drempelverhogend (i.c. kleinere zouttolerantie) en in welke mate? Hoe implementeren we deze nieuwe informatie in het operationele zoetwaterbeheer?

2. In Nederland is de zoutbelasting van landbouwgewassen in de vollegrond (op landbouwpercelen) tot nu toe nauwelijks gemeten. Op zich begrijpelijk omdat de maatschappelijke urgentie ontbrak. We weten echter nog steeds niet aan welke stress plantenwortels in tijden van droogte en/of bij aanvoer van brak beregeningswater daadwerkelijk worden blootgesteld.

3. Boeren meten in de praktijk vaak de EC van het slootwater als maat voor de kwaliteit van het oppervlaktewater. Dit geeft slechts indirect informatie over de mate van zoutstress die het gewas in de wortelzone ervaart. Ten behoeve van de bruikbaarheid van maatregelen is het nodig om meer inzicht te krijgen in de relatie tussen de EC in het slootwater en het optreden van zoutschade. Deze informatie moet bij voorkeur worden verstrekt door de boeren zelf.

4. Wat zijn de toxische effecten van 'zout' op landbouwgewassen? Heeft dit direct gevolgen voor de opbrengst?

5. Hoe ontwikkelt de zouttolerantie van landbouwgewassen zich gedurende het groeiseizoen? Kunnen gewassen schade herstellen en zo ja, ten koste waarvan?

6. In het veld wordt geregeld opgemerkt dat zoutschade te verkiezen is boven droogteschade. Er is echter nog weinig bekend over hoe droogte- en zoutschade vergeleken en afgewogen moeten worden en wat de gevolgen zijn voor opbrengst en kwaliteit.

7. Wat zijn de effecten van 'zout' op de kwaliteit en/of smaak van geteelde producten?

8. Het gedeelte van een gewasareaal (ha) dat tijdens een teelt daadwerkelijk wordt beregend is in veel gevallen beperkt; vaak minder dan $10 \%{ }^{13}$. Het is dus de vraag hoe groot het risico op zoutschade ten gevolge van beregening van een bepaald gewas in werkelijkheid is. Informatie hierover is helaas schaars, maar wel essentieel voor het optimaliseren van het voorzieningenniveau rond het operationele zoetwaterbeheer in verziltingsgevoelige gebieden.

\section{Aanbevelingen}

Gegeven de geconstateerde kennishiaten zou in vervolgonderzoek aandacht moeten zijn voor de volgende aspecten:

1. Vaststellen van verbanden tussen een verhoogd zoutgehalte in perceelsloten met wateraanvoer enerzijds, en zoutschade aan gewassen op hieraan grenzende percelen anderzijds, te constateren door boeren/telers als rapporteurs. Combinaties met interviews en voorlichtingsbijeenkomsten.

2. 'Big Data': beschikbare datasets met opbrengsten van grondgebonden teelten van de afgelopen jaren (bron: (Wageningen Economic Research ${ }^{14}$ ) in verband brengen met weergegevens (KNMI), de actuele vegetatiekaart 'Groenmonitor ${ }^{15}$, CBS Statline ${ }^{16}$ en dergelijke.

3. Verzamelen van meetgegevens, op landbouwpercelen, aan gewassen die blootgesteld worden aan beregeningswater met verhoogd zoutgehalte; intensieve meetcampagne; boven- en ondergronds.

4. Kwantificeren van zoutschade onder gecontroleerde omstandigheden (kassen), met aandacht voor (i) relatie zouttolerantie-groeistadium, (ii) interactie natrium-kalium, (iii) adaptatievermogen van gewassen ('afharden') e.d.

5. Toepassing van de nieuwe kennis in Waterwijzer landbouw 'Zout'.

6. In Nederland is de gewoonte om een zoutgehalte uit te drukken in milligram Chloride per liter volledig ingeburgerd. Het verdient aanbeveling om over te schakelen op het Elektrisch Geleidingsvermogen (EGV), oftewel EC (=Electric Conductivity), een werkwijze die in buiten Nederland allang gemeengoed is.

\footnotetext{
${ }_{14}^{13}$ Gegevens gebaseerd op informatie, afkomstig uit Noord- en Zuid-Holland, voor het jaar 2010.

${ }_{15}^{14}$ www.wur.nl/nl/Expertises-Dienstverlening/Onderzoeksinstituten/Economic-Research.htm

${ }_{16}^{15}$ http://www.groenmonitor.nl/

16 http://statline.cbs.nl/Statweb/
} 


\section{$5 \quad$ Zouttoleranties van 35 gewassen en gewasgroepen}

Gedetailleerde informatie over de inventarisatie van de op de Nederlandse situatie geënte publicaties (rapporten, literatuur) en ongepubliceerde 'lijstjes' met gerapporteerde zouttolerantiedrempels van beregeningswater die in dit project is gemaakt, is samengebracht in paragraaf 5.1 (pagina 48) tot en met 5.35 (pagina 147) waar voor elk(e) gewas(groep) informatie is samengebracht. Deze informatie is als volgt opgebouwd:

A) 'Literatuur': een kort bespreking van de gebruikte informatiebronnen, inclusief 'Referenties'.

B) 'Gegevens': een schematisch gepresenteerd overzicht van de informatie uit de bronnen, ondergebracht in twee tabellen.

De bovenste tabel, ingekleurd, bevat een weergave van de gerapporteerde zoutschadedrempels, afgezet in $\mathrm{m} \mathrm{Cl}^{-} /$liter (boven), en tegen de tijd in jaren (onder).

De tabel hieronder bevat getalsmatige informatie over de gerapporteerde zoutschadedrempels, inclusief de meest bepalende kenmerken. Als hierover informatie is gerapporteerd zijn deze kenmerken aangekruist.

C) 'Interpretatie': een grafische weergave van het resultaat van het 'fitten' van een standaardnormale kansverdeling aan de in B) gerapporteerde zouttolerantiedrempels, te weten rekenkundig gemiddelde en de spreiding, uitgedrukt in het $40 \%$ betrouwbaarheidsinterval. 


\subsection{Grasland}

\section{A. Literatuur}

Rowaan (1951) geeft een overzicht van het inundatieonderzoek in Nederland tot 1944 en haalt werk aan van laboratoriumonderzoek van Zijlstra uit 1946 over zoutgevoeligheid van een aantal gewassen i.v.m. de cultuur op Zuiderzeegronden. De gewassenkeuze na een overstroming wordt vooral bepaald door de meer of mindere zoutgevoeligheid van de afzonderlijke gewassen. Bij de onderzochte gewassen (zomertarwe, erwt, witte klaver en verschillende grassoorten) werd een meer vertraagde kieming gevonden naarmate de concentratie van het zoute water hoger was. Bij concentraties tot $10.000 \mathrm{mg} / \mathrm{l}$ keukenzout per liter was de invloed op het uiteindelijk kiemingseffect bij de meeste gewassen nog gering.

Couwenhoven (1971) meldt n.a.v. onderzoek van Zijlstra bij bevloeiing van Engels raaigras met een voedingsoplossing van $2600 \mathrm{mg} \mathrm{Cl} / \mathrm{l}$, een drogestofvermindering van $10 \%$.

In ICW Nota 1461 (Jansen, 1983) wordt een waarde van $600 \mathrm{mg} / \mathrm{l}$ vermeld als het toelaatbare chloridegehalte in het aangevoerde oppervlaktewater (perceelsloot) voor grasland. De auteur, Peter Jansen, thans werkzaam bij Onderzoekinstituut Alterra, vermeldt niet waar deze waarde vandaan komt, en kan zich dat ook niet herinneren (Ing. P.C. Jansen, persoonlijke mededeling, 2016). Uit het Handboek Melkveehouderij (1997) stamt de waarde van 975 mg/l Cl, een gemiddelde van de door het "Praktijkonderzoek Rundvee, Schapen en Paarden" vermelde waarden die tussen 800 en $1150 \mathrm{mg} / \mathrm{l} \mathrm{Cl}$ voor grasland dienen te liggen.

Het literatuuronderzoek 'Actualisering Zouttolerantie', Roest et al. (2003), dat werd uitgevoerd ten behoeve van de ontwikkeling van het RIZA-instrumentarium, leidde tot een grenswaarde die varieerde tussen van 950 en 962 mg/l Cl voor de zouttolerantie van grasland, afhankelijk van de geraadpleegde studies.

In 2009 werd de studie "Review of crop salt tolerance in the Netherlands" uitgevoerd door van Bakel et al. (2009). In dit project werden met behulp van het computermodel SWAP (Wageningen UR Alterra) de volgende drempelwaarden voor $0 \%$ gewasschade bij grasland op drie verschillende bodems in het droogste jaar 1976 vastgesteld: $700 \mathrm{mg} / \mathrm{l} \mathrm{Cl}$ voor zandgrond, $1900 \mathrm{mg} / \mathrm{l}$ voor zavelgrond en $900 \mathrm{mg} / \mathrm{l}$ voor kleigrond (Alterra-rapport 1926).

\section{Referenties}

Bakel P.J.T., R.A.L. Kselik, C.W.J. Roest en A.A.M.F.R. Smit. 2009. Review of crop salt tolerance in the Netherlands. Rapport 1926, Alterra, Wageningen.

Couwenhoven, T., 1971. De verzilting en het gebruik van sproeiwater in de akkerbouw. Bedrijfsontwikkeling 2, editie Akkerbouw. Instituut voor Cultuurtechniek en Waterhuishouding, Wageningen, p 53-63.

Praktijkonderzoek Veehouderij, 1997. Handboek melkveehouderij. Uitgeverij Praktijkonderzoek Veehouderij, Lelystad, p 44.

Jansen, P.C., 1983. Waterkwaliteit. Een beknopt overzicht van begrippen, parameters, typering en normen. Instituut voor Cultuurtechniek en Waterhuishouding, ICW-Nota 1461, Wageningen. pp. 26-28.

Roest, C.W.J., P.J.T. van Bakel \&, A.A.M.F.R. Smit, 2003. Actualisering van de zouttolerantie van landen tuinbouwgewassen ten behoeve van de berekening van de zoutschade in Nederland met het RIZA-instrumentarium. Memo Alterra, Wageningen, $16 \mathrm{p}$.

Rowaan, P.A., 1951. Overzicht van inundatie-onderzoek in Nederland tot 1944. De inundaties gedurende 1944-1945 en hun gevolgen voor de landbouw Deel III. Verslagen van Landbouwkundige Onderzoekingen 57.3, 36 pp.

Zijlstra, K., 1946. Over de gevoeligheid van eenige landbouwgewassen voor zeewater. Verslagen van Landbouwkundige Onderzoekingen 52 (2), 25-51. 


\section{B. Gegevens}
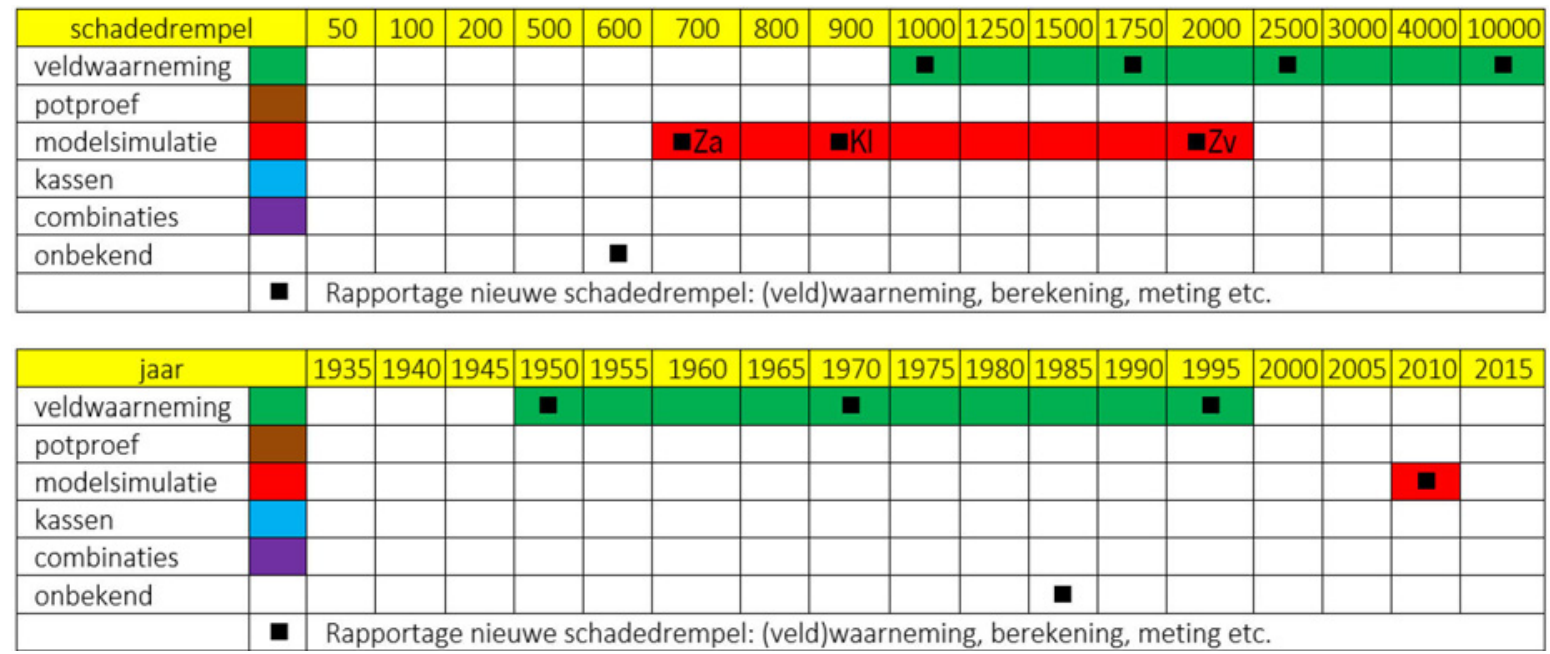

\begin{tabular}{|c|c|c|c|c|c|c|c|c|c|c|c|c|c|c|c|c|c|}
\hline \multirow{2}{*}{ No } & \multirow{2}{*}{ Gewas(groep) } & \multirow[b]{2}{*}{$\begin{array}{l}\frac{\#}{\frac{\#}{0}} \\
\frac{0}{E} \\
\frac{\omega}{0}\end{array}$} & \multirow[b]{2}{*}{ 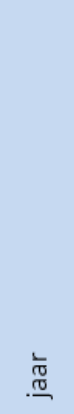 } & \multirow[b]{2}{*}{ 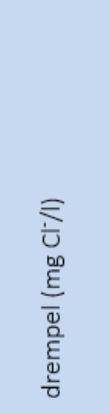 } & \multirow{2}{*}{ 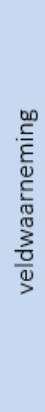 } & \multirow{2}{*}{ 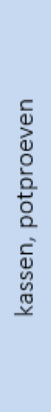 } & \multirow{2}{*}{ 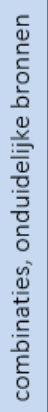 } & \multirow{2}{*}{ 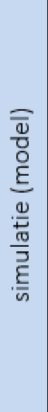 } & \multirow{2}{*}{ 모 } & \multirow{2}{*}{$\stackrel{D}{N}_{N}^{\bar{N}}$} & \multirow{2}{*}{$\frac{\bar{\alpha}}{\underline{\underline{\alpha}}}$} & \multirow{2}{*}{ 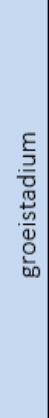 } & \multirow{2}{*}{ 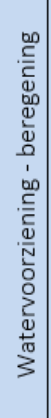 } & \multirow{2}{*}{ 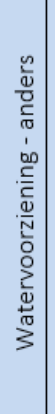 } & \multirow{2}{*}{ 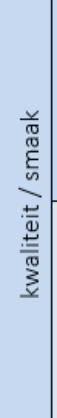 } & \multicolumn{2}{|c|}{$\begin{array}{c}\text { Gerapporteerde } \\
\text { drempel; [rekenkundig } \\
\text { gemiddelde] }\end{array}$} \\
\hline & & & & & & & & & & & & & & & & $\begin{array}{c}\mathrm{Cl}^{-} \\
\text {(mg/liter) }\end{array}$ & $\begin{array}{c}E C \\
(\mathrm{dS} / \mathrm{m})\end{array}$ \\
\hline \multirow{10}{*}{1} & \multirow{10}{*}{ Grasland } & 1 & 1951 & 10000 & $x$ & & & & & & & & & & & \multirow{10}{*}{2055} & \multirow{10}{*}{7,3} \\
\hline & & 2 & 1971 & 2600 & $x$ & & & & & & & & $x$ & & & & \\
\hline & & 3 & 1983 & 600 & & & $x$ & & & & & & & & & & \\
\hline & & 4 & 1997 & 975 & & & $x$ & & & & & & & & & & \\
\hline & & 5 & 2003 & 962 & & & $x$ & & & & & & $x$ & & & & \\
\hline & & 6 & 2003 & 962 & & & $\times$ & & & & & & $x$ & & & & \\
\hline & & 7 & 2003 & 950 & & & $x$ & & & & & & $x$ & & & & \\
\hline & & 8 & 2009 & 700 & & & & $x$ & $x$ & & & & $x$ & & & & \\
\hline & & 9 & 2009 & 900 & & & & $x$ & & & $x$ & & $x$ & & & & \\
\hline & & 10 & 2009 & 1900 & & & & $x$ & & $x$ & & & $x$ & & & & \\
\hline
\end{tabular}


C. Interpretatie

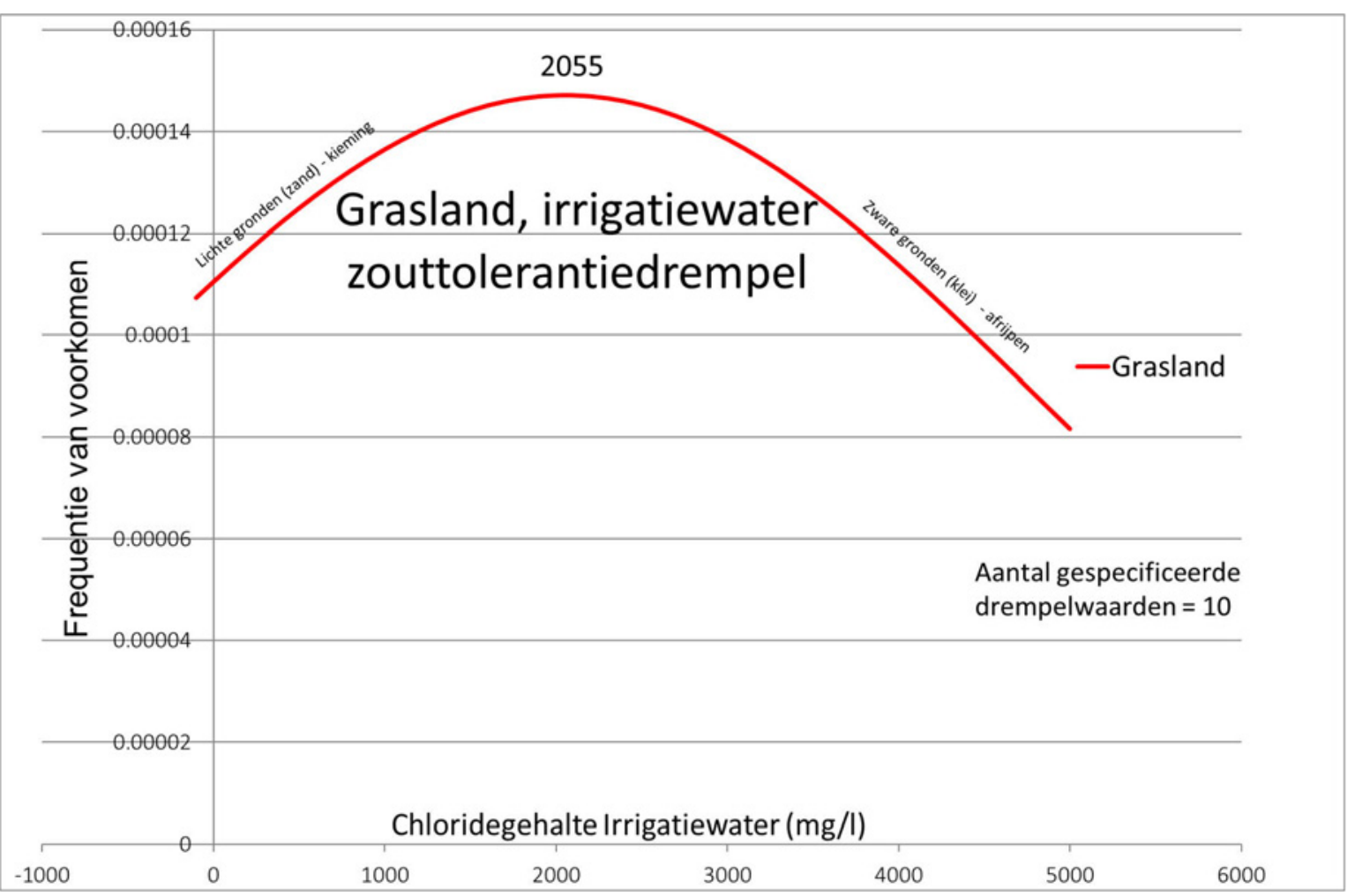

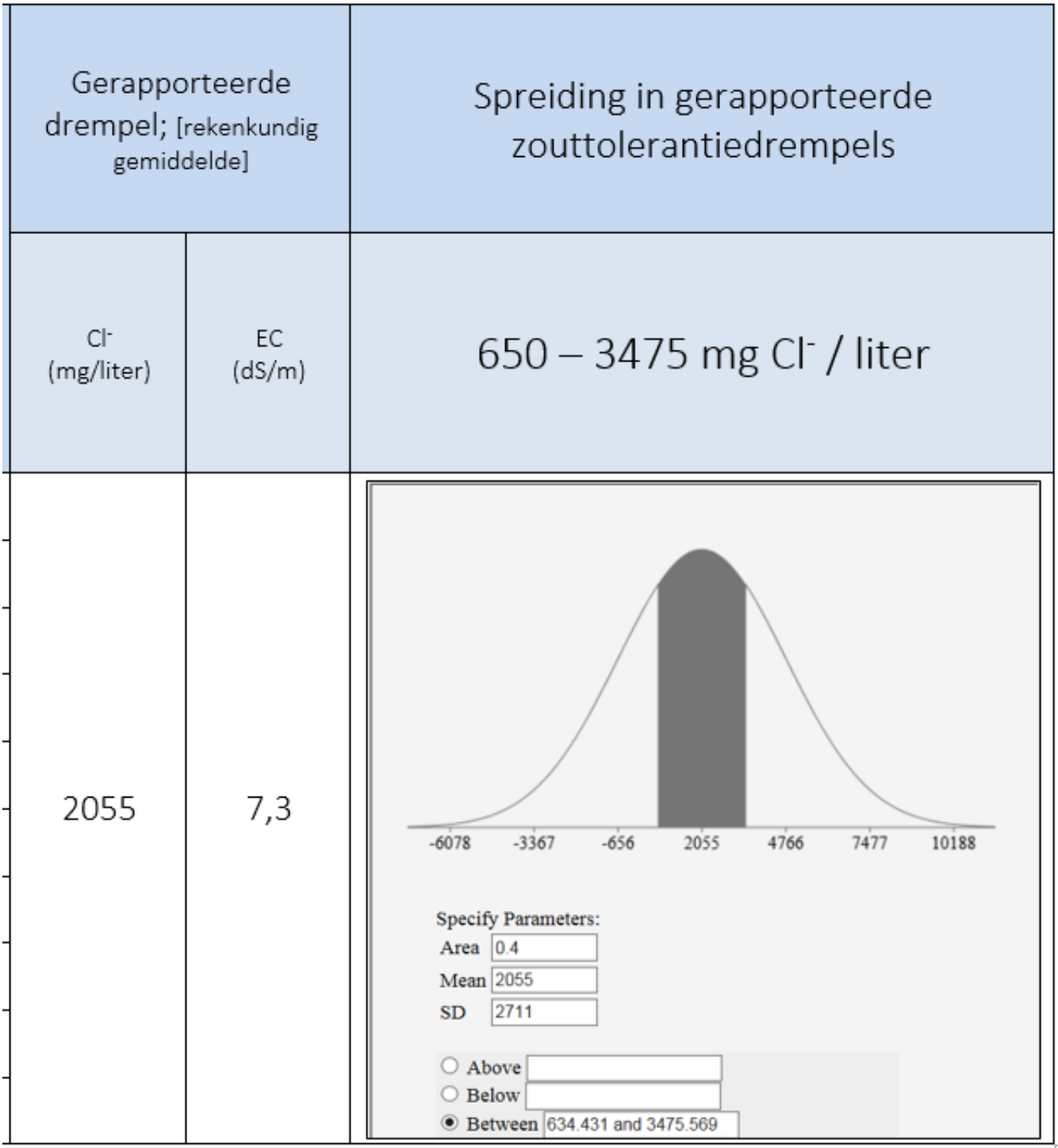




\subsection{Tarwe, gerst}

\section{A. Literatuur}

Rowaan (1951) geeft overzicht van het inundatieonderzoek in Nederland tot 1944 en haalt werk aan van laboratoriumonderzoek, uitgevoerd door Zijlstra uit 1946 over de zoutgevoeligheid van een aantal gewassen i.v.m. de nieuwe cultuur op Zuiderzeegronden, waaronder tarwe. Bij concentraties tot $10.000 \mathrm{mg} / \mathrm{l}$ keukenzout per liter was de invloed op het uiteindelijk kiemingseffect nog gering. Couwenhoven (1971) refereert naar onderzoek van Zijlstra (1946) die bij bevloeiing van zomertarwe met een voedingsoplossing van $1700 \mathrm{mg} \mathrm{Cl} / \mathrm{l}$, een drogestofvermindering vond van $10 \%$. In 1983 wordt in ICW Nota 1461 (P.C. Jansen) $600 \mathrm{mg} / \mathrm{l} \mathrm{Cl}$ vermeld voor het toelaatbare chloridegehalte in het oppervlaktewater voor bouwland (alg).

Het literatuuronderzoek 'Actualisering Zouttolerantie' door Roest et al. (2003), dat werd uitgevoerd ten behoeve van de ontwikkeling en het gebruik van het RIZA-instrumentarium, leidde tot grenswaarden die varieerden van 1050 voor gietwater bij granen voor het $10 \%$ gevoeligste gewas. In hetzelfde rapport wordt de waarde $1288 \mathrm{mg} / \mathrm{l}$ in het gietwater gerapporteerd; deze is gebruikt in het computer simulatiemodel Agricom.

Alterra rapport 2201 (Bakel en Stuyt, 2011) vermeldt in Tabel 4 de normen voor gebruikswaarden in beregeningswater gerelateerd aan zoutgehalte, afkomstig uit het PAGV-handboek (de Jonge, 1981) met waarden tussen 900 en 1200 mg/l Cl voor weinig gevoelige akkerbouwgewassen waaronder granen.

Eurofins (2015a) categoriseert granen als weinig gevoelige akkerbouwgewassen met een zouttolerantiedrempel van 900-1200 mg. De bron(nen) van de in dit informatieblad gespecificeerde drempelwaarde( $n)$ zouttolerantie in beregeningswater konden - ondanks gerichte navraag - niet worden achterhaald.

\section{Referenties}

Bakel, P.J.T. van en L.C.P.M. Stuyt, 2011. Actualisering van de kennis van de zouttolerantie van landbouwgewassen, op basis van literatuuronderzoek, expertkennis en praktische ervaringen. Wageningen, Alterra-rapport 2201.

Couwenhoven, T., 1971. De verzilting en het gebruik van sproeiwater in de akkerbouw. Bedrijfsontwikkeling 2, editie Akkerbouw. Instituut voor Cultuurtechniek en Waterhuishouding, Wageningen, p 53-63.

Eurofins, 2015a. Waterkwaliteit in de akkerbouw. Bijlage/Toelichting. Eurofins Agro Laboratories, Wageningen.

Jansen, P.C., 1983. Waterkwaliteit. Een beknopt overzicht van begrippen, parameters, typering en normen. Instituut voor Cultuurtechniek en Waterhuishouding, ICW-Nota 1461, Wageningen. pp. 26-28.

Roest, C.W.J., P.J.T. van Bakel \&, A.A.M.F.R. Smit, 2003. Actualisering van de zouttolerantie van landen tuinbouwgewassen ten behoeve van de berekening van de zoutschade in Nederland met het RIZA-instrumentarium. Memo Alterra, Wageningen, $16 \mathrm{p}$.

Rowaan, P.A., 1951. Overzicht van inundatie-onderzoek in Nederland tot 1944. De inundaties gedurende 1944-1945 en hun gevolgen voor de landbouw Deel III. Verslagen van Landbouwkundige Onderzoekingen 57.3, 36 pp.

Zijlstra, K., 1946. Over de gevoeligheid van eenige landbouwgewassen voor zeewater. Verslagen van Landbouwkundige Onderzoekingen 52 (2), 25-51. 


\section{B. Gegevens}

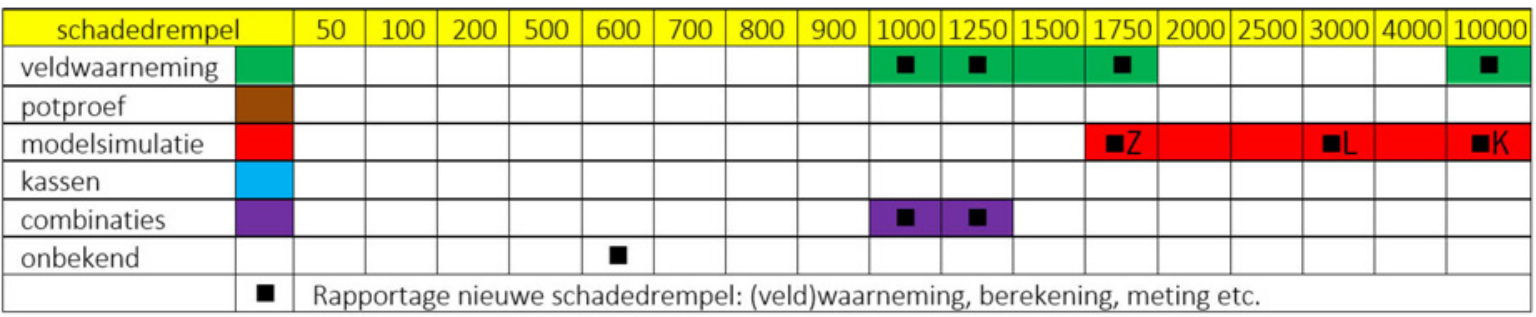

\begin{tabular}{|c|c|c|c|c|c|c|c|c|c|c|c|c|c|c|c|c|c|c|}
\hline jaar & & 1935 & 1940 & 1945 & 1950 & 1955 & 1960 & 1965 & 1970 & 1975 & 1980 & 1985 & 1990 & 1995 & 2000 & 2005 & 2010 & 2015 \\
\hline veldwaarneming & & & & & 口 & & & & 口 & & & & & & & & & 口 \\
\hline potproef & & & & & & & & & & & & & & & & & & \\
\hline kassen & & & & & & & & & & & & & & & & & & \\
\hline combinaties & & & & & & & & & & & & & & & & 무 & & \\
\hline onbekend & & & & & & & & & & & & $\mathbf{a}$ & & & & & & \\
\hline
\end{tabular}

\begin{tabular}{|c|c|c|c|c|c|c|c|c|c|c|c|c|c|c|c|}
\hline No & Gewas(groep) & 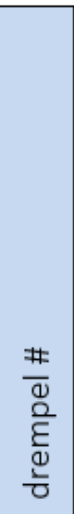 & 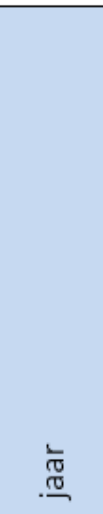 & 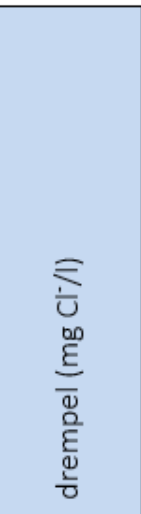 & 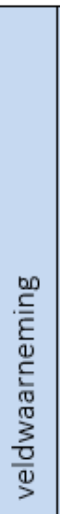 & 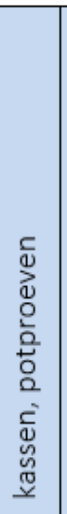 & 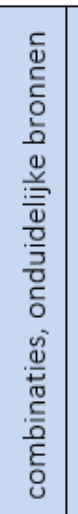 & 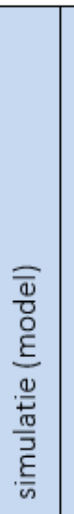 & $\begin{array}{l}\text { D } \\
\text { C్ } \\
\text { N }\end{array}$ & 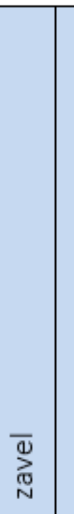 & $\frac{\bar{\omega}}{\bar{x}}$ & 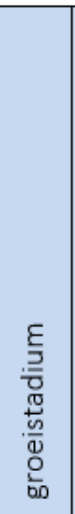 & 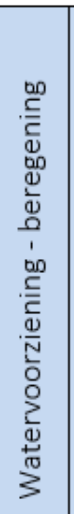 & 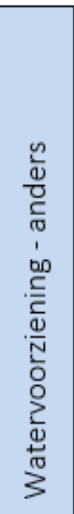 & 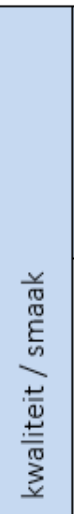 \\
\hline \multirow{11}{*}{2} & \multirow{11}{*}{ Tarwe, gerst } & 1 & 1951 & 10000 & $x$ & & & & & & & & & & \\
\hline & & 2 & 1971 & 1700 & $x$ & & & & & & & & & & \\
\hline & & 3 & 1983 & 600 & $x$ & & & & & & & & & & \\
\hline & & 4 & 2003 & 1288 & & & $x$ & & & & & & & & \\
\hline & & 5 & 2003 & 1053 & & & $x$ & & & & & & $x$ & & \\
\hline & & 6 & 2003 & 1050 & & & $\times$ & & & & & & $x$ & & \\
\hline & & 7 & 2009 & 1600 & & & $x$ & & $x$ & & & & $x$ & & \\
\hline & & 8 & 2009 & 3200 & & & $x$ & & & & $x$ & & & & \\
\hline & & 9 & 2009 & 6300 & & & $x$ & & & $x$ & & & & & \\
\hline & & 10 & 2015 & 900 & & & & & & & & & & & \\
\hline & & 11 & 2015 & 1200 & & & & & & & & & & & \\
\hline
\end{tabular}


C. Interpretatie

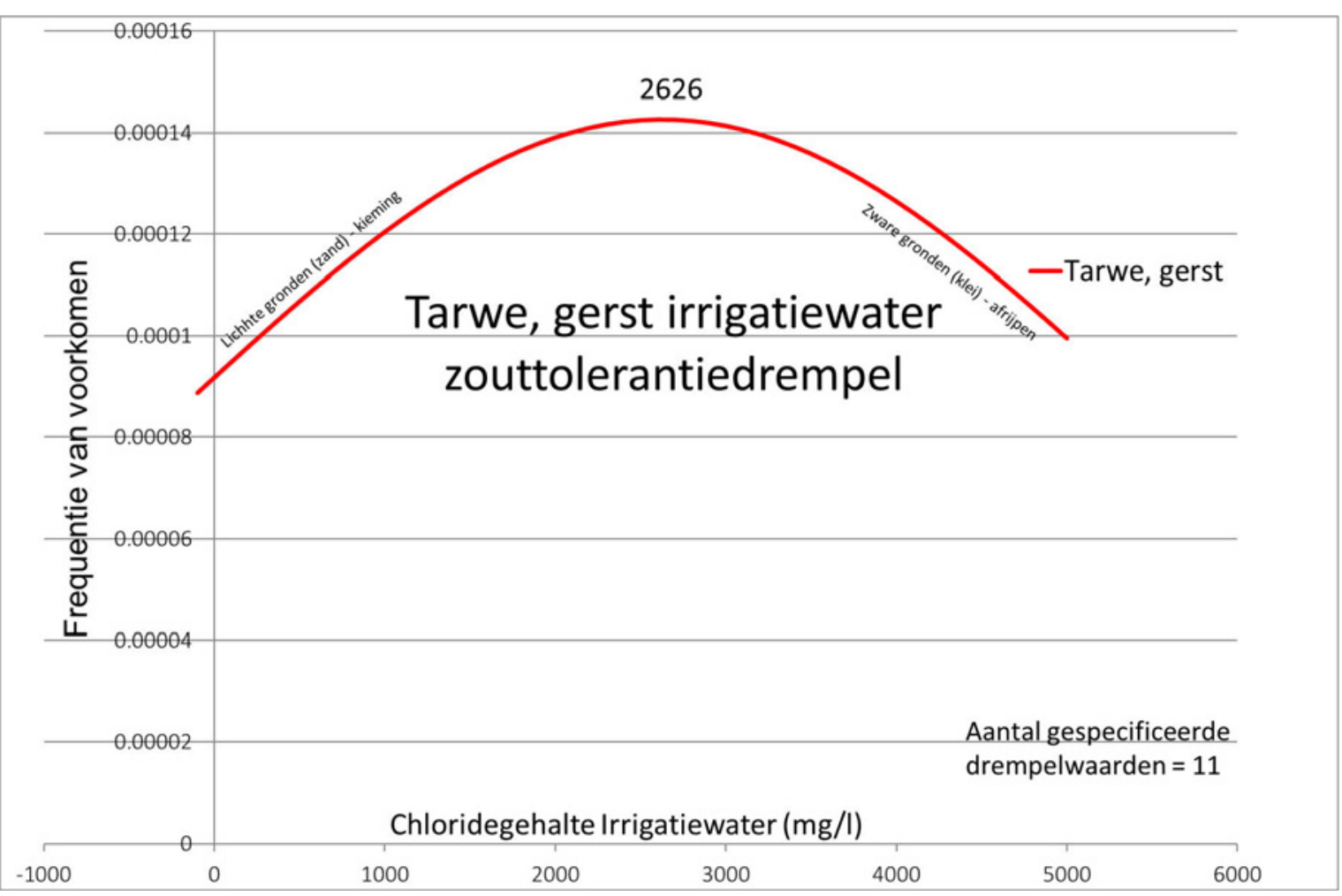

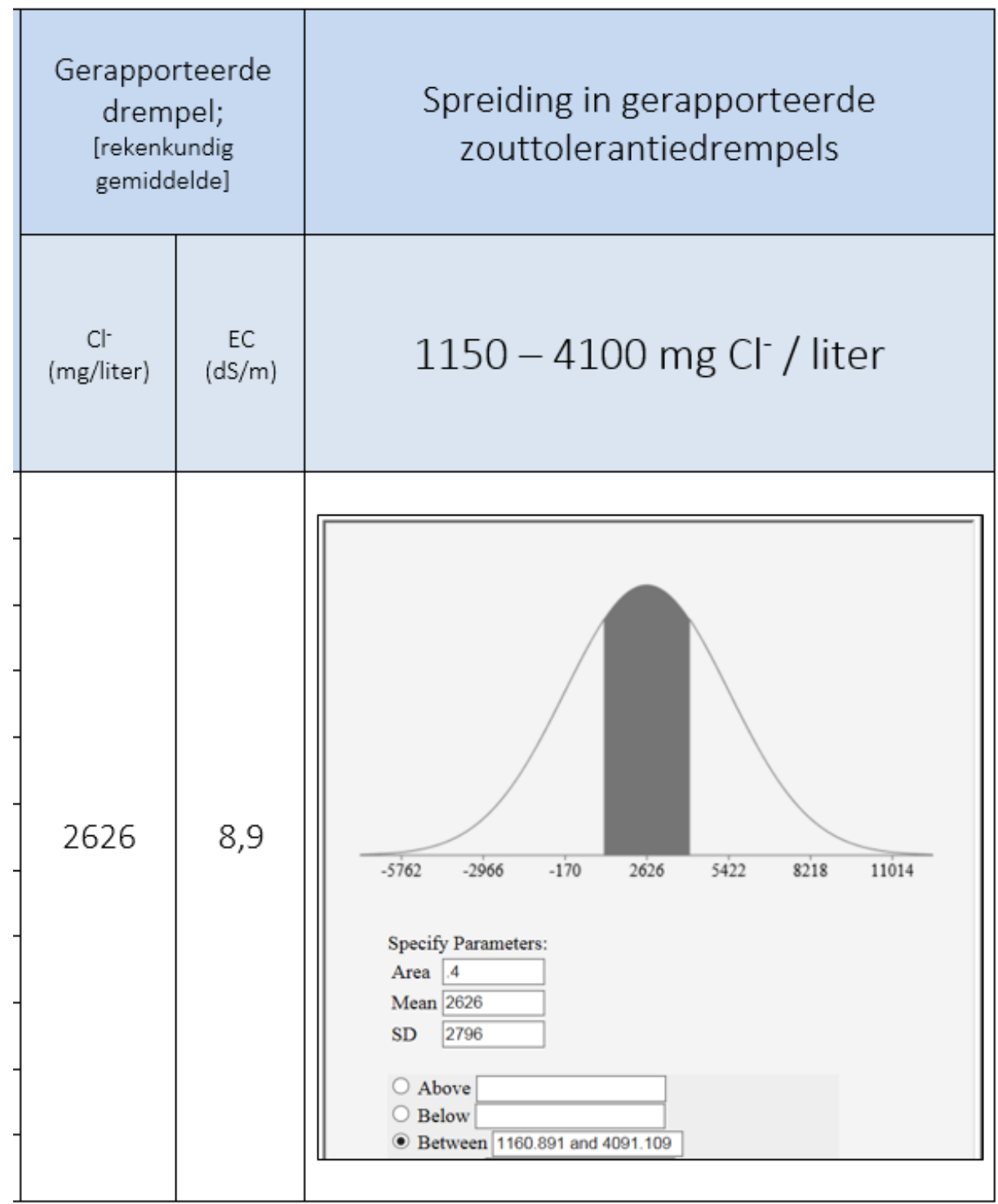




\subsection{Klaver (Luzerne)}

\section{A. Literatuur}

Rowaan (1951) geeft een overzicht van het inundatieonderzoek in Nederland tot 1944 en haalt werk aan van laboratoriumonderzoek van Zijlstra uit 1946 over zoutgevoeligheid van een aantal gewassen i.v.m. de cultuur op Zuiderzeegronden waaronder ook klaver. Bij concentraties tot $10.000 \mathrm{mg} / \mathrm{l}$ keukenzout per liter bleek de invloed op het uiteindelijk kiemingseffect bij de meeste gewassen nog gering.

\section{Referenties}

Rowaan, P.A., 1951. Overzicht van inundatie-onderzoek in Nederland tot 1944. De inundaties gedurende 1944-1945 en hun gevolgen voor de landbouw Deel III. Verslagen van Landbouwkundige Onderzoekingen 57.3, 36 pp.

Zijlstra, K., 1946. Over de gevoeligheid van eenige landbouwgewassen voor zeewater. Verslagen van Landbouwkundige Onderzoekingen 52 (2), 25-51.

\section{B. Gegevens}

\begin{tabular}{|c|c|c|c|c|c|c|c|c|c|c|c|c|c|c|c|c|c|c|}
\hline schadedrempel & & 50 & 100 & 200 & 500 & 600 & 700 & 800 & 900 & 1000 & 1250 & 1500 & 1750 & 2000 & 2500 & 3000 & 4000 & 10000 \\
\hline veldwaarneming & & & & & & & & & & & & & & & & & & 口 \\
\hline potproef & & & & & & & & & & & & & & & & & & \\
\hline modelsimulatie & & & & & & & & & & & & & & & & & & \\
\hline kassen & & & & & & & & & & & & & & & & & & \\
\hline combinaties & & & & & & & & & & & & & & & & & & \\
\hline onbekend & & & & & & & & & & & & & & & & & & \\
\hline & a & Rapp & port? & nit & Iwe & nade & $m$ & (velc & d) waat & rnemin & $\mathrm{ng}, \mathrm{b}$ & rekenın & $n g, n$ & eting & & & & \\
\hline
\end{tabular}

\begin{tabular}{|c|c|c|c|c|c|c|c|c|c|c|c|c|c|c|c|c|c|c|}
\hline jaar & & 1935 & 1940 & 1945 & 1950 & 1955 & 1960 & 1965 & 1970 & 1975 & 1980 & 1985 & 1990 & 1995 & 2000 & 2005 & 2010 & 2015 \\
\hline veldwaarneming & & & & & 口 & & & & & & & & & & & & & \\
\hline potproef & & & & & & & & & & & & & & & & & & \\
\hline modelsimulatie & & & & & & & & & & & & & & & & & & \\
\hline kassen & & & & & & & & & & & & & & & & & & \\
\hline combinaties & & & & & & & & & & & & & & & & & & \\
\hline onbekend & & & & & & & & & & & & & & & & & & \\
\hline & 口 & Rar & & nis & & adr & rempel & al: (veld & d)waar & inemin & ing, ber & rekeni & ing, me & eting et & & & & \\
\hline
\end{tabular}

\begin{tabular}{|c|c|c|c|c|c|c|c|c|c|c|c|c|c|c|c|}
\hline No & Gewas(groep) & 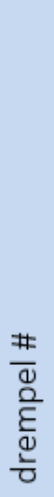 & 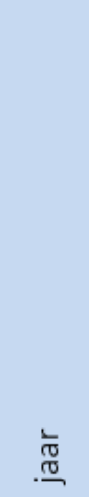 & 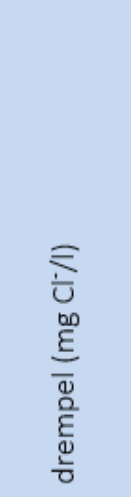 & 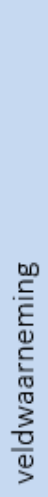 & 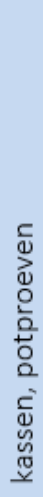 & 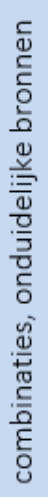 & 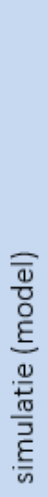 & 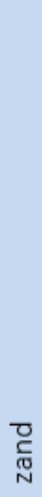 & 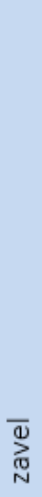 & $\frac{\bar{\alpha}}{\underline{x}}$ & 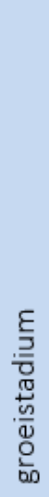 & 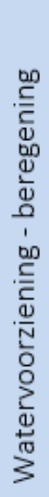 & 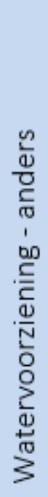 & 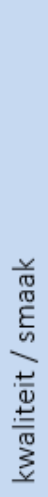 \\
\hline 3 & $\begin{array}{l}\text { Klaver } \\
\text { (Luzerne) }\end{array}$ & 1 & 1951 & 10000 & $\times$ & & & & & & & & & $x$ & \\
\hline
\end{tabular}




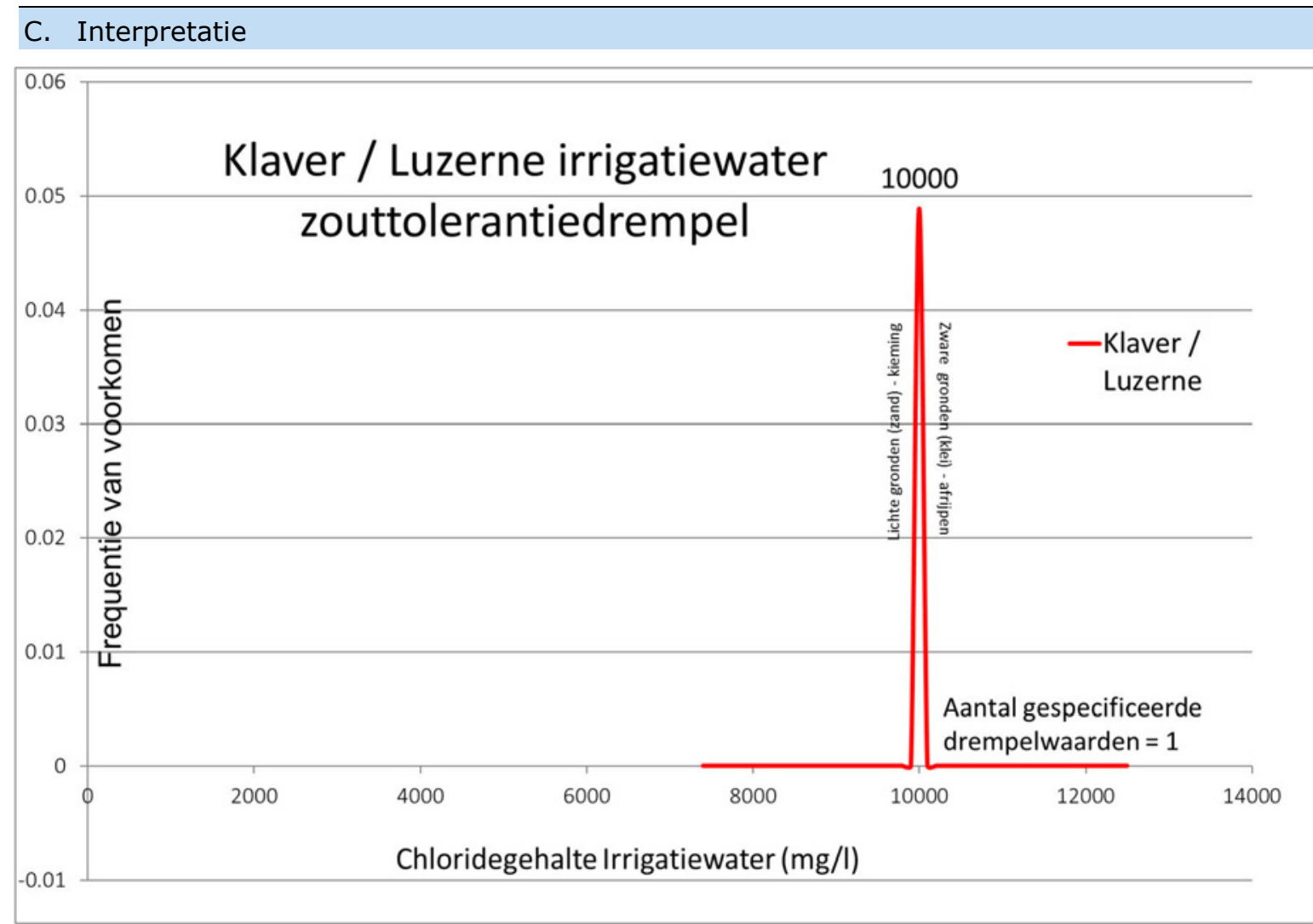

\begin{tabular}{|c|c|c|}
\hline \multicolumn{2}{|c|}{$\begin{array}{c}\text { Gerapporteerde } \\
\text { drempel; [rekenkundig } \\
\text { gemiddelde] }\end{array}$} & $\begin{array}{c}\text { Spreiding in gerapporteerde } \\
\text { zouttolerantiedrempels }\end{array}$ \\
\hline $\begin{array}{c}\mathrm{Cl}^{-} \\
(\mathrm{mg} / \text { liter })\end{array}$ & $\begin{array}{c}\mathrm{EC} \\
(\mathrm{dS} / \mathrm{m})\end{array}$ \\
\hline 10000 & 24,6 & \\
\hline
\end{tabular}




\subsection{Snijmais}

\section{A. Literatuur}

In 1983 wordt in ICW Nota 1461 (P.C. Jansen) $600 \mathrm{mg} / \mathrm{l} \mathrm{Cl}$ vermeld voor het toelaatbare chloridegehalte in het oppervlaktewater voor bouwland.

Uit het literatuuronderzoek "Actualisering Zouttolerantie", uitgevoerd door Roest et al. (2003) dat werd uitgevoerd ten behoeve van de ontwikkeling en het gebruik van het RIZA-instrumentarium is een waarde voor het $10 \%$ gevoeligste gewas afgeleid, waarbij voor snijmaïs een afgeronde waarde van $200 \mathrm{mg} / \mathrm{l} \mathrm{Cl}$ wordt aangehouden.

In 2009 werd de studie "Review of crop salt tolerance in the Netherlands" uitgevoerd. In dit project zijn, mede met behulp van 'expert judgement' de volgende drempelwaarden voor $0 \%$ gewasschade bij snijmais vastgesteld: $300 \mathrm{mg} / \mathrm{l} \mathrm{Cl}$ voor zandgrond, $1350 \mathrm{mg} / \mathrm{l}$ voor zavelgrond en $650 \mathrm{mg} / \mathrm{l}$ voor kleigrond (Alterra-rapport 1926).

\section{Referenties}

Bakel P.J.T., R.A.L. Kselik, C.W.J. Roest en A.A.M.F.R. Smit. 2009. Review of crop salt tolerance in the Netherlands. Rapport 1926, Alterra, Wageningen.

Jansen, P.C., 1983. Waterkwaliteit. Een beknopt overzicht van begrippen, parameters, typering en normen. Instituut voor Cultuurtechniek en Waterhuishouding, ICW-Nota 1461, Wageningen. pp. 26-28.

Roest, C.W.J., P.J.T. van Bakel \&, A.A.M.F.R. Smit, 2003. Actualisering van de zouttolerantie van landen tuinbouwgewassen ten behoeve van de berekening van de zoutschade in Nederland met het RIZA-instrumentarium. Memo Alterra, Wageningen, $16 \mathrm{p}$. 


\section{B. Gegevens}

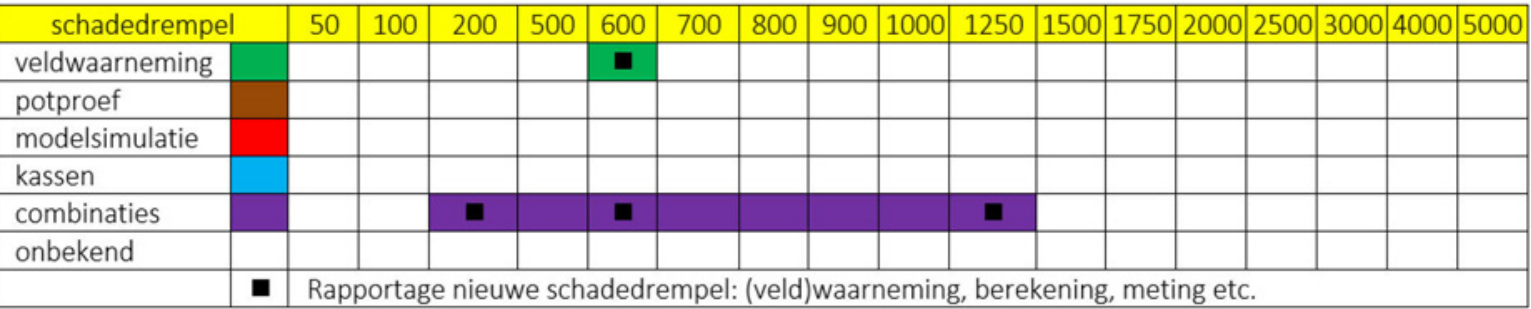

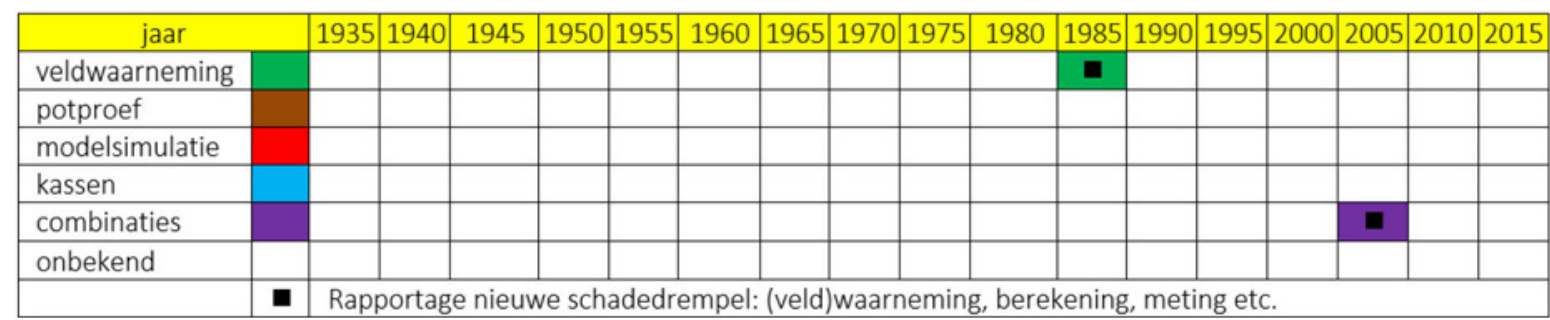

\begin{tabular}{|c|c|c|c|c|c|c|c|c|c|c|c|c|c|c|c|c|c|}
\hline \multirow{2}{*}{ No } & \multirow{2}{*}{ Gewas(groep) } & \multirow[b]{2}{*}{ 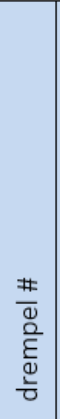 } & \multirow[b]{2}{*}{ 离 } & \multirow[b]{2}{*}{ 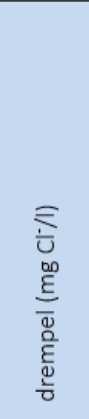 } & \multirow[b]{2}{*}{ 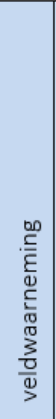 } & \multirow[b]{2}{*}{ 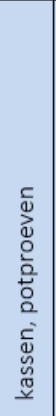 } & \multirow{2}{*}{ 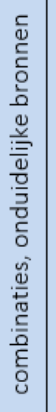 } & \multirow[b]{2}{*}{ 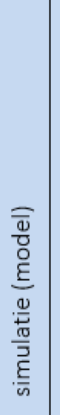 } & \multirow[b]{2}{*}{ 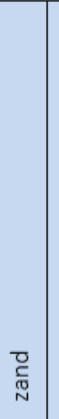 } & \multirow[b]{2}{*}{ 离 } & \multirow[b]{2}{*}{$\frac{\bar{w}}{\underline{y}}$} & \multirow{2}{*}{\multicolumn{2}{|c|}{ 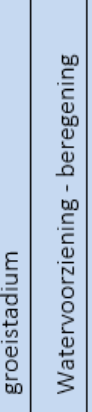 }} & \multirow{2}{*}{\multicolumn{2}{|c|}{ 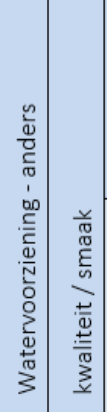 }} & \multicolumn{2}{|c|}{$\begin{array}{l}\text { Gerapporteerde } \\
\text { drempel; [rekenkundig } \\
\text { gemiddelde] }\end{array}$} \\
\hline & & & & & & & & & & & & & & & & $\begin{array}{c}\mathrm{Cl} \\
(\mathrm{mg} / \text { liter) }\end{array}$ & $\begin{array}{c}E C \\
(\mathrm{~d} S / \mathrm{m})\end{array}$ \\
\hline \multirow{6}{*}{4} & \multirow{6}{*}{ Snijmais } & 1 & 2003 & 217 & & & $x$ & & & & & & $x$ & & & \multirow{6}{*}{498} & \multirow{6}{*}{2,5} \\
\hline & & 2 & 2003 & 217 & & & $x$ & & & & & & $x$ & & & & \\
\hline & & 3 & 2003 & 200 & & & $x$ & & & & & & $x$ & & & & \\
\hline & & 4 & 2009 & 300 & & & $x$ & & $x$ & & & & & & & & \\
\hline & & 5 & 2009 & 650 & & & $x$ & & & & $x$ & & & & & & \\
\hline & & 6 & 2009 & 1300 & & & $x$ & & $x$ & & & & & & & & \\
\hline
\end{tabular}


C. Interpretatie

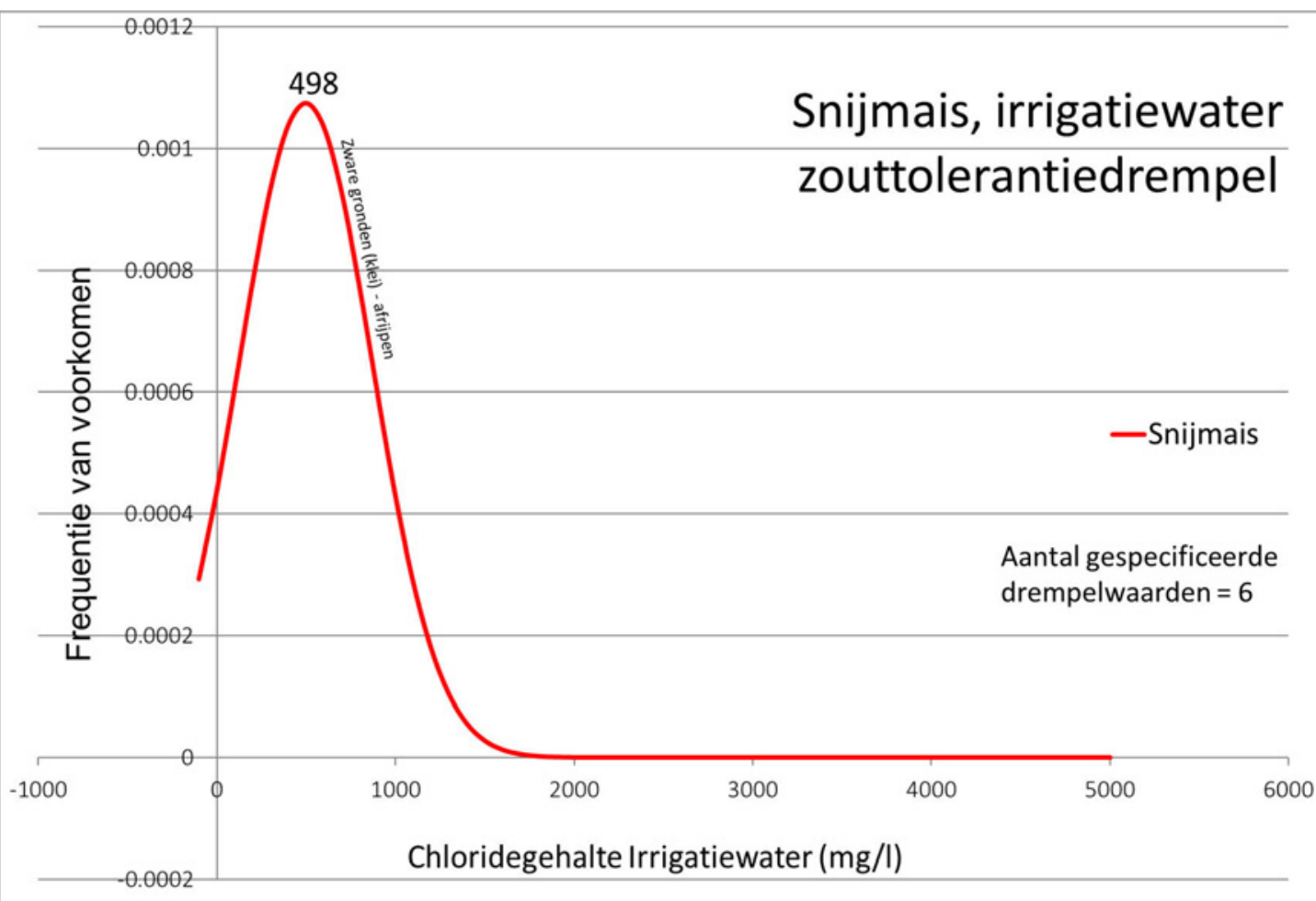

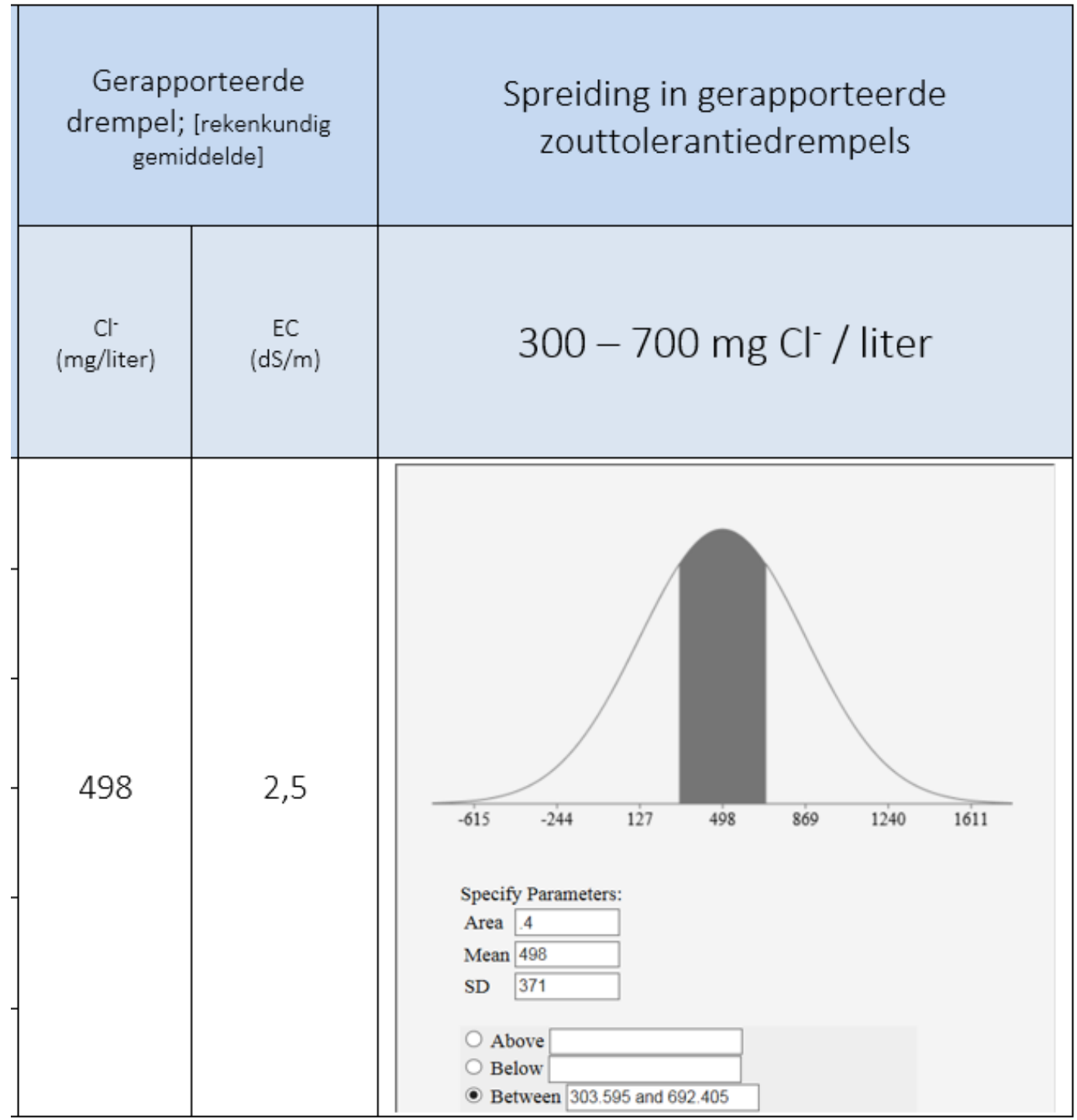




\title{
5.5 Radijs, spinazie, erwten, bonen
}

\begin{abstract}
A. Literatuur
Van der Valk (ICW, 1962) verrichtte onderzoek d.m.v. veldproeven met zout irrigatiewater aan sla, bonen en bloemkool. Doseringen tot $2500 \mathrm{mg} \mathrm{Cl}$ per liter in het beregeningswater bleken in het natte jaar 1962 geen nadelige invloed op de opbrengst te hebben. Wel trad er bij hoge doseringen ernstig structuurverval op.
\end{abstract}

Uit het literatuuronderzoek Actualisering Zouttolerantie door Roest et al. (2003), dat werd uitgevoerd ten behoeve van de ontwikkeling en het gebruik van het RIZA-instrumentarium, werd een waarde van $100 \mathrm{mg} / \mathrm{l} \mathrm{Cl}$ voor het $10 \%$ gevoeligste gewas in deze categorie afgeleid. In hetzelfde rapport worden waarden gerapporteerd die bij het landbouwmodel 'Agricom' werden gebruikt, te weten 245 mg/l in het gietwater.

In Alterra rapport 2201 (Bakel en Stuyt, 2011) is in Tabel 4 een door DLV Plant voor beregeningswater gehanteerde drempelwaarde van ca. $375 \mathrm{mg} \mathrm{Cl} / \mathrm{l}$ opgenomen.

Eurofins (2015a) categoriseert bloemkool als matig gevoelige vollegrondsgroente met een zouttolerantiedrempel van $600-900 \mathrm{mg}$, en spinazie als weinig gevoelige vollegrondsgroente met een zouttolerantiedrempel van 900-1200 mg. De bron(nen) van de in dit informatieblad gespecificeerde drempelwaarde $(n)$ zouttolerantie in beregeningswater konden - ondanks gerichte navraag - niet worden achterhaald.

\section{Referenties}

Bakel P.J.T., R.A.L. Kselik, C.W.J. Roest en A.A.M.F.R. Smit. 2009. Review of crop salt tolerance in the Netherlands. Rapport 1926, Alterra, Wageningen.

Bakel, P.J.T. van en L.C.P.M. Stuyt, 2011. Actualisering van de kennis van de zouttolerantie van landbouwgewassen, op basis van literatuuronderzoek, expertkennis en praktische ervaringen. Wageningen, Alterra-rapport 2201.

Eurofins, 2015a. Waterkwaliteit in de akkerbouw. Bijlage/Toelichting. Eurofins Agro Laboratories, Wageningen.

ICW, 1962. Jaarverslag van het Instituut voor Cultuurtechniek en Waterhuishouding (ICW) van het instituut voor cultuurtechniek en waterhuishouding. Mededeling ICW 48, Wageningen, p 11.

Roest, C.W.J., P.J.T. van Bakel \&, A.A.M.F.R. Smit, 2003. Actualisering van de zouttolerantie van landen tuinbouwgewassen ten behoeve van de berekening van de zoutschade in Nederland met het RIZA-instrumentarium. Memo Alterra, Wageningen, $16 \mathrm{p}$. 


\section{B. Gegevens}
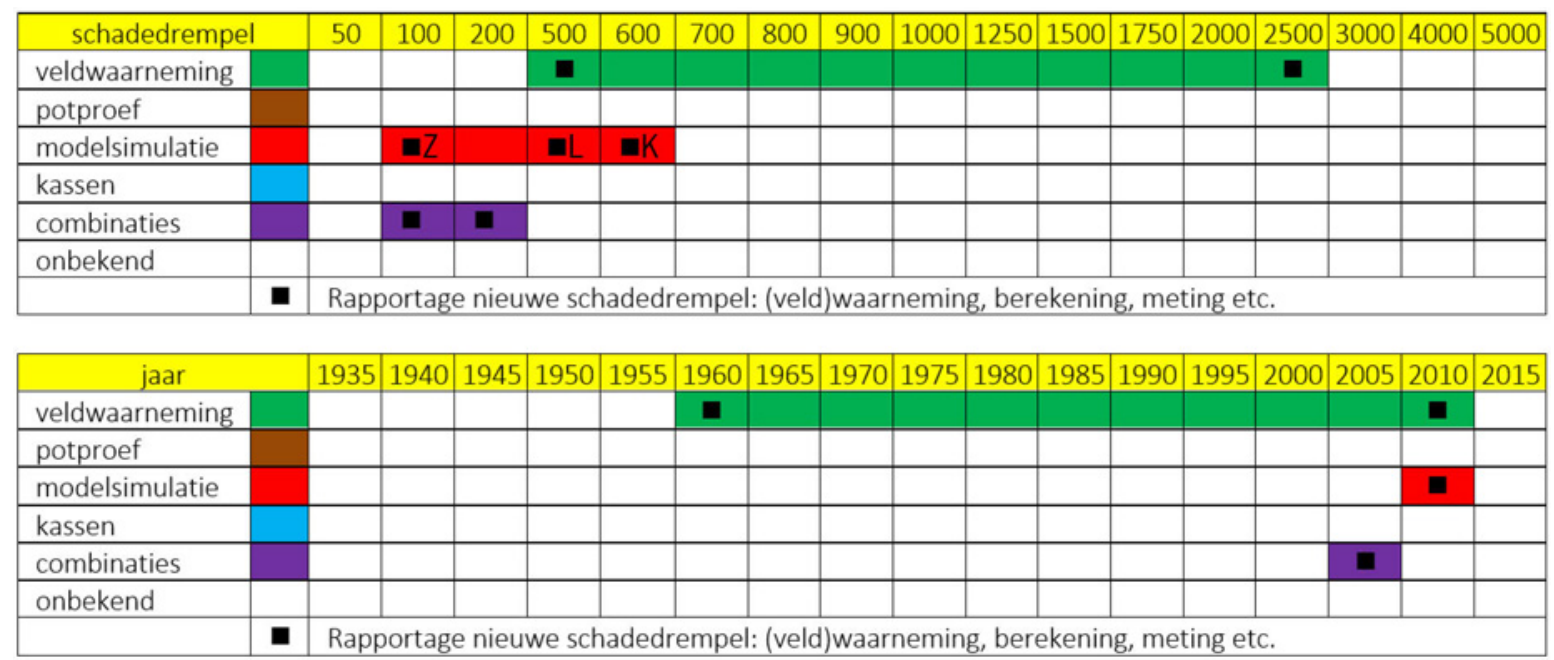

\begin{tabular}{|c|c|c|c|c|c|c|c|c|c|c|c|c|c|c|c|}
\hline No & Gewas(groep) & 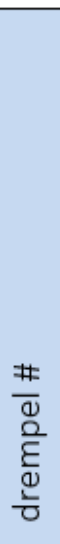 & 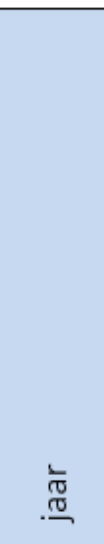 & 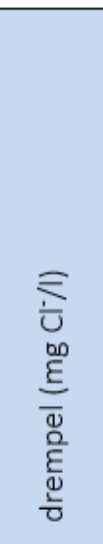 & 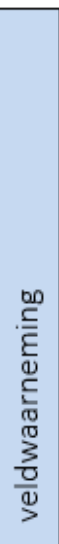 & 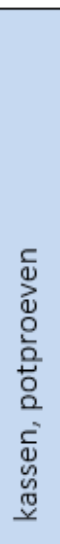 & 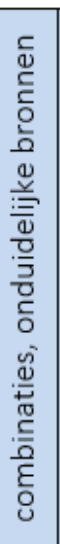 & 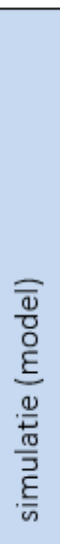 & 胥 & 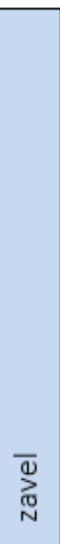 & $\frac{\bar{\omega}}{\underline{y}}$ & 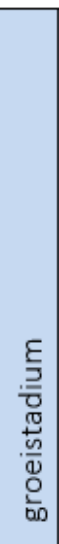 & 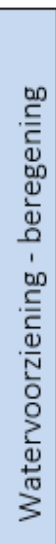 & 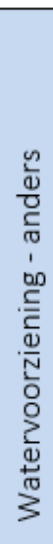 & 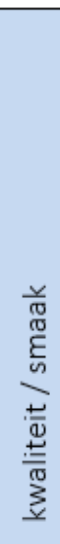 \\
\hline \multirow{8}{*}{5} & \multirow{8}{*}{$\begin{array}{l}\text { Radijs, } \\
\text { spinazie, } \\
\text { erwten, } \\
\text { bonen }\end{array}$} & 1 & 1962 & 2500 & $x$ & & $x$ & & & & & & $x$ & & \\
\hline & & 2 & 2003 & 245 & & & $x$ & & & & & & $\times$ & & \\
\hline & & 3 & 2003 & 101 & & & $x$ & & & & & & $x$ & & \\
\hline & & 4 & 2003 & 100 & & & $x$ & & & & & & $x$ & & \\
\hline & & 5 & 2009 & 150 & & & $x$ & & & & & & & & \\
\hline & & 6 & 2009 & 300 & & & $x$ & & & & & & & & \\
\hline & & 7 & 2009 & 600 & & & $x$ & & & & & & & & \\
\hline & & 8 & 2011 & 375 & $x$ & & & & & & & & & & \\
\hline
\end{tabular}


C. Interpretatie

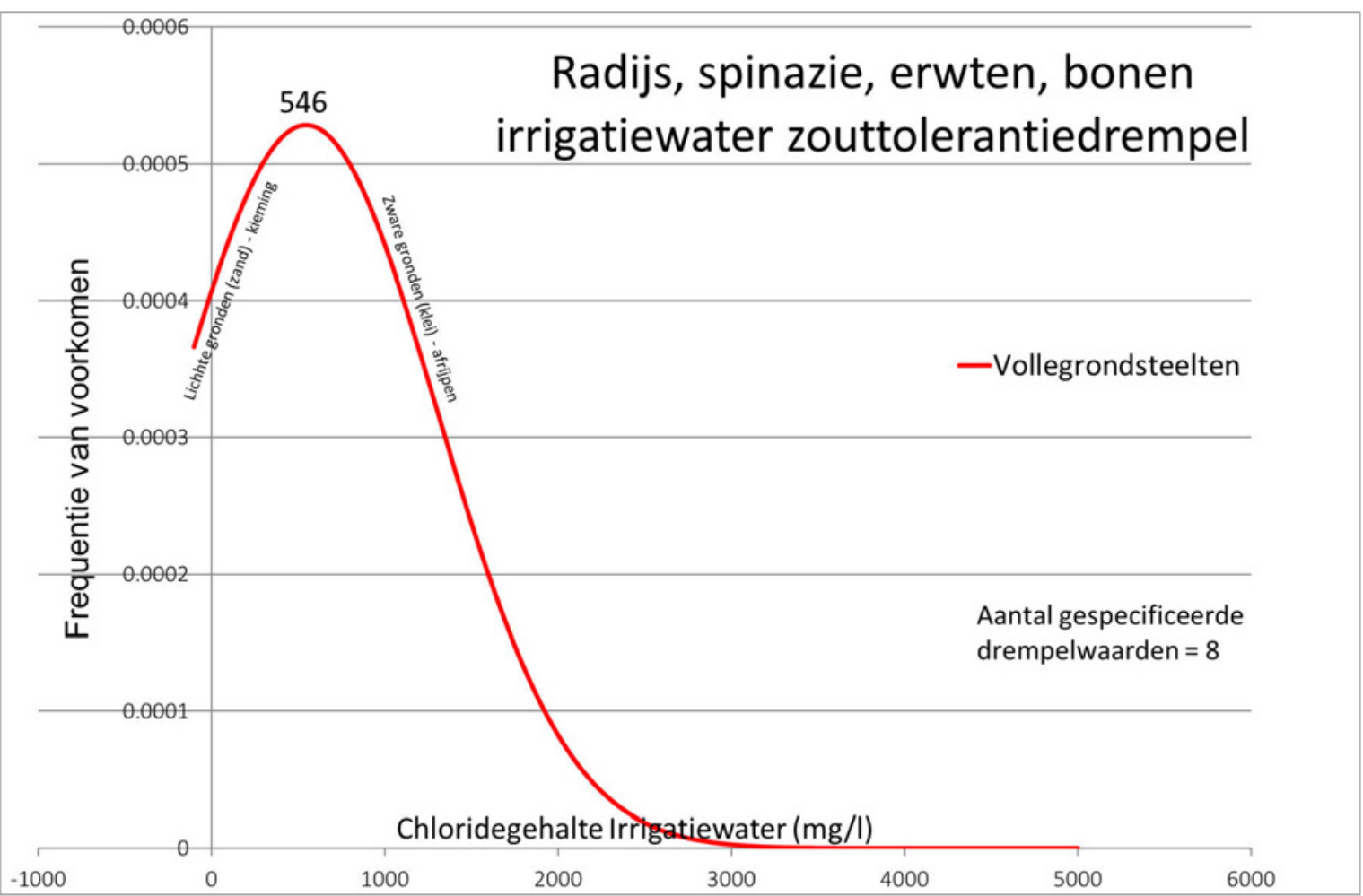

De eerste drempelwaarde ( $2500 \mathrm{mg} \mathrm{Cl}^{-} / \mathrm{l}$ ) is wegens de natte omstandigheden in 1962 en het feit dat de gegevens sterk gedateerd zijn, bij de statistische analyse uiteindelijk niet in beschouwing genomen; het aantal gerapporteerde drempels dat in de analyse is meegenomen daalt van 8 naar 7 , en de gemiddelde drempelwaarde van 546 naar 267.

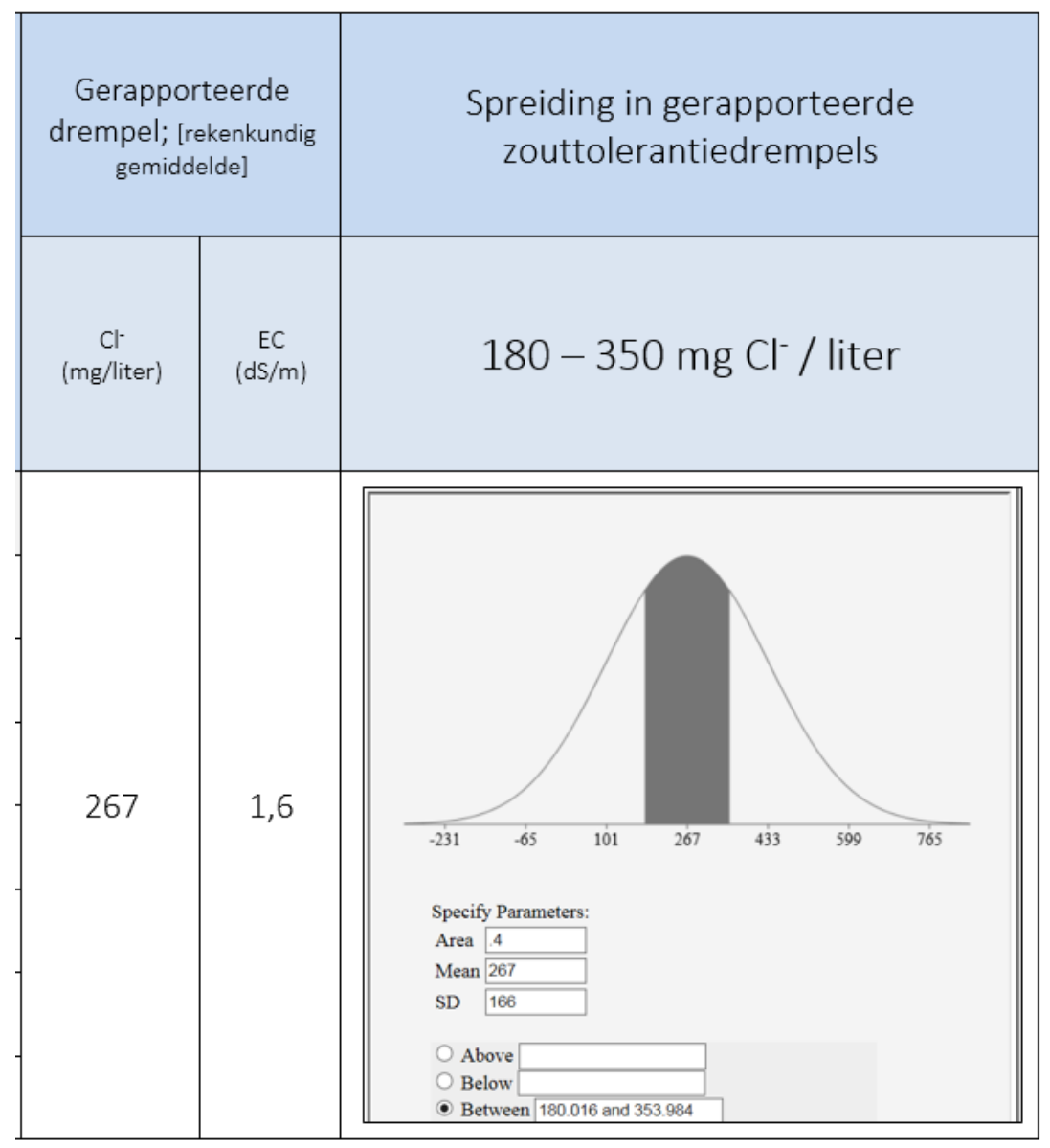




\subsection{Spruiten, witlof, boerenkool, radijs}
A. Literatuur gehanteerd:

$\begin{array}{llc}\text { Bij lage tolerantie: } & \text { Bron: DLV, } & 1070 \mathrm{mg} \mathrm{CL} / \mathrm{I} \\ \text { Bij hoge tolerantie: } & \text { Bron: DLV, } & 1200 \mathrm{mg} \mathrm{CL/l} \\ \text { Bij lage tolerantie: } & \text { Bron: PAGV, } & 900 \mathrm{mg} \mathrm{CL} / \mathrm{l} \\ \text { Bij hoge tolerantie: } & \text { Bron: PAGV, } & 1200 \mathrm{mg} \mathrm{CL/l}\end{array}$

In Alterra rapport 2201 "Actualisering Zouttolerantie" (Bakel en Stuyt, 2011) is de tabel "Risico op zoutschade aan landbouwgewassen bij verschillende zoutgehalten van beregeningswater" beschikbaar gesteld door DLV Plant, die gebruikt wordt voor advisering. Ook is in dit rapport een tabel met zouttolerantiewaarden opgenomen uit het PAGV-handboek (Proefstation voor de akkerbouw en de groetenteelt in de volle grond). Voor spruiten worden in deze tabellen de volgende waarden

Eurofins (2015a) categoriseert spruitkool, witlof, boerenkool en radijs als weinig gevoelige vollegrondsgroente met een zouttolerantiedrempel van 900-1200 mg. De bron(nen) van de in dit informatieblad gespecificeerde drempelwaarde( $n$ ) zouttolerantie in beregeningswater konden ondanks gerichte navraag - niet worden achterhaald.

\section{Referenties}

Bakel P.J.T., R.A.L. Kselik, C.W.J. Roest en A.A.M.F.R. Smit. 2009. Review of crop salt tolerance in the Netherlands. Rapport 1926, Alterra, Wageningen.

Bakel, P.J.T. van en L.C.P.M. Stuyt, 2011. Actualisering van de kennis van de zouttolerantie van landbouwgewassen, op basis van literatuuronderzoek, expertkennis en praktische ervaringen. Wageningen, Alterra-rapport 2201.

Eurofins, 2015a. Waterkwaliteit in de akkerbouw. Bijlage/Toelichting. Eurofins Agro Laboratories, Wageningen. 


\section{B. Gegevens}

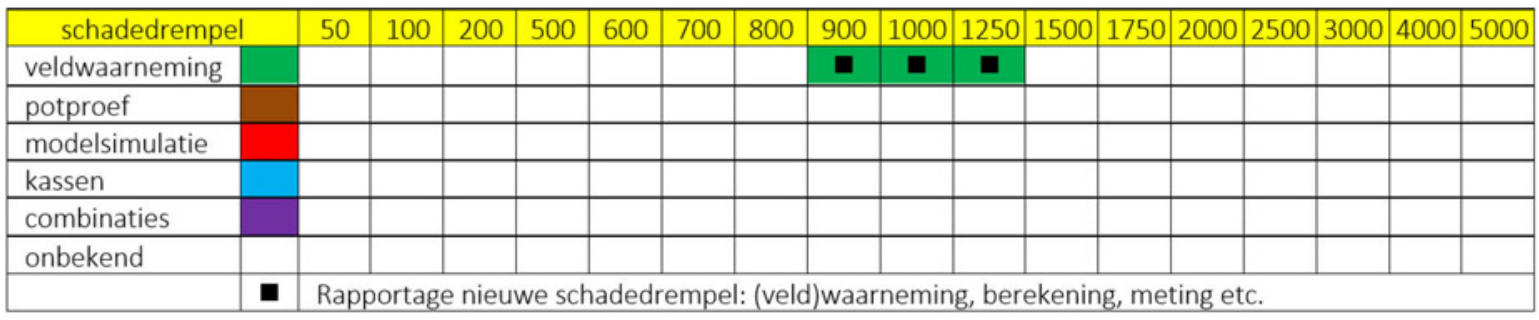

\begin{tabular}{|c|c|c|c|c|c|c|c|c|c|c|c|c|c|c|c|c|c|c|}
\hline jaar & & 1935 & 1940 & 1945 & 1950 & 1955 & 1960 & 1965 & 1970 & 1975 & 1980 & 1985 & 1990 & 1995 & 2000 & 2005 & 2010 & 2015 \\
\hline veldwaarneming & & & & & & & & & & & & & & & & & & 口 \\
\hline potproef & & & & & & & & & & & & & & & & & & \\
\hline kassen & & & & & & & & & & & & & & & & & & \\
\hline combinaties & & & & & & & & & & & & & & & & & & \\
\hline onbekend & & & & & & & & & & & & & & & & & & \\
\hline
\end{tabular}

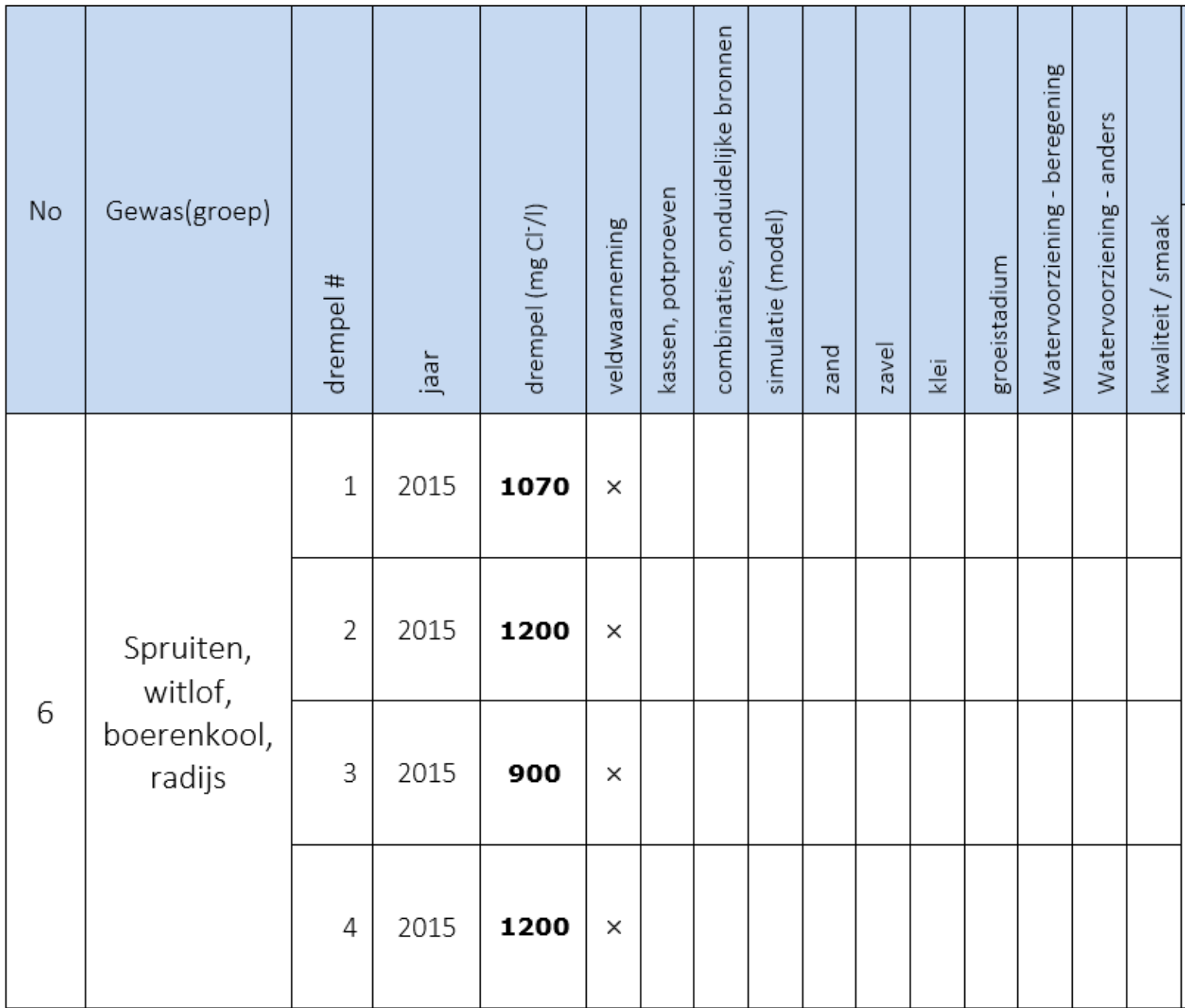


C. Interpretatie

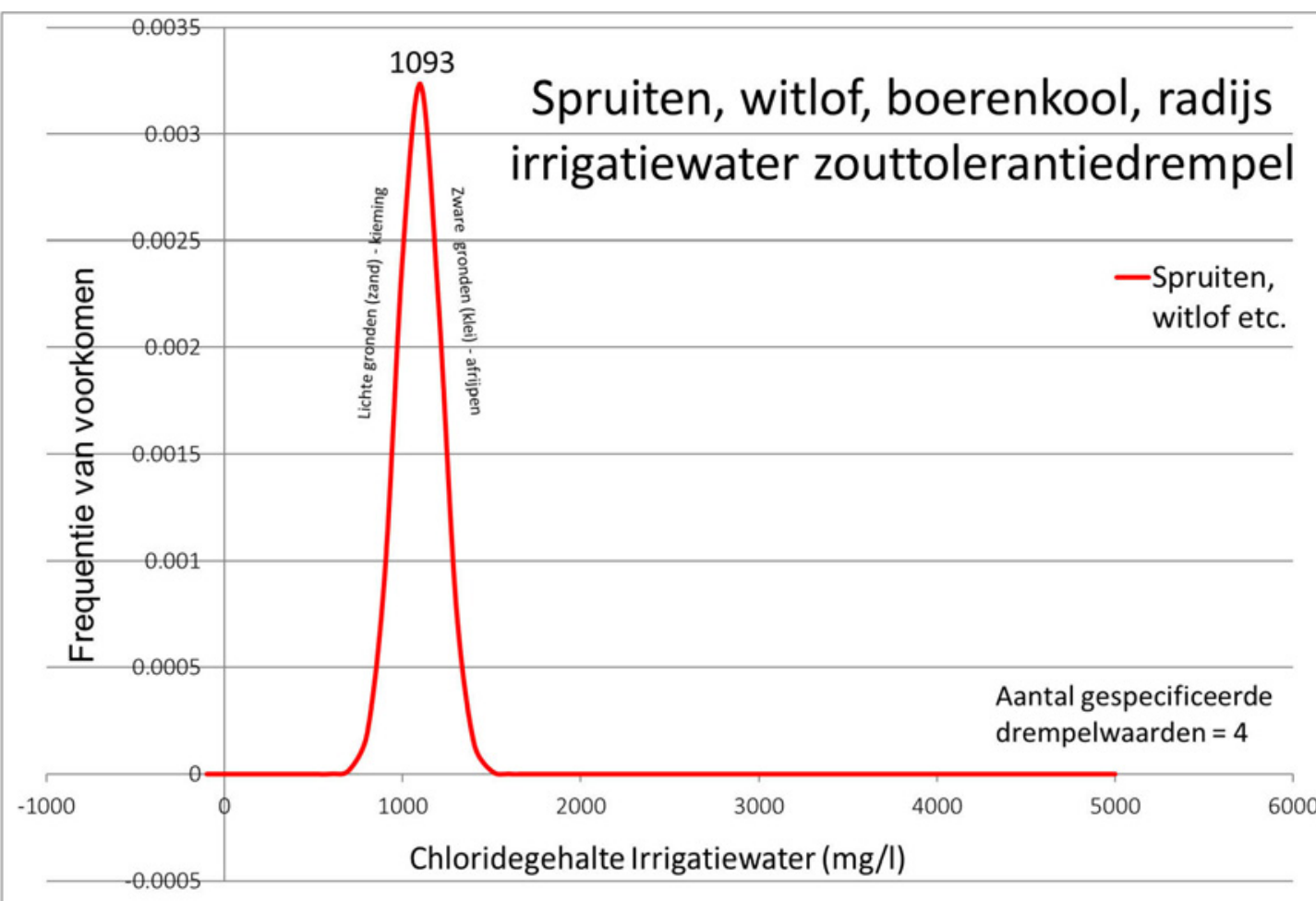

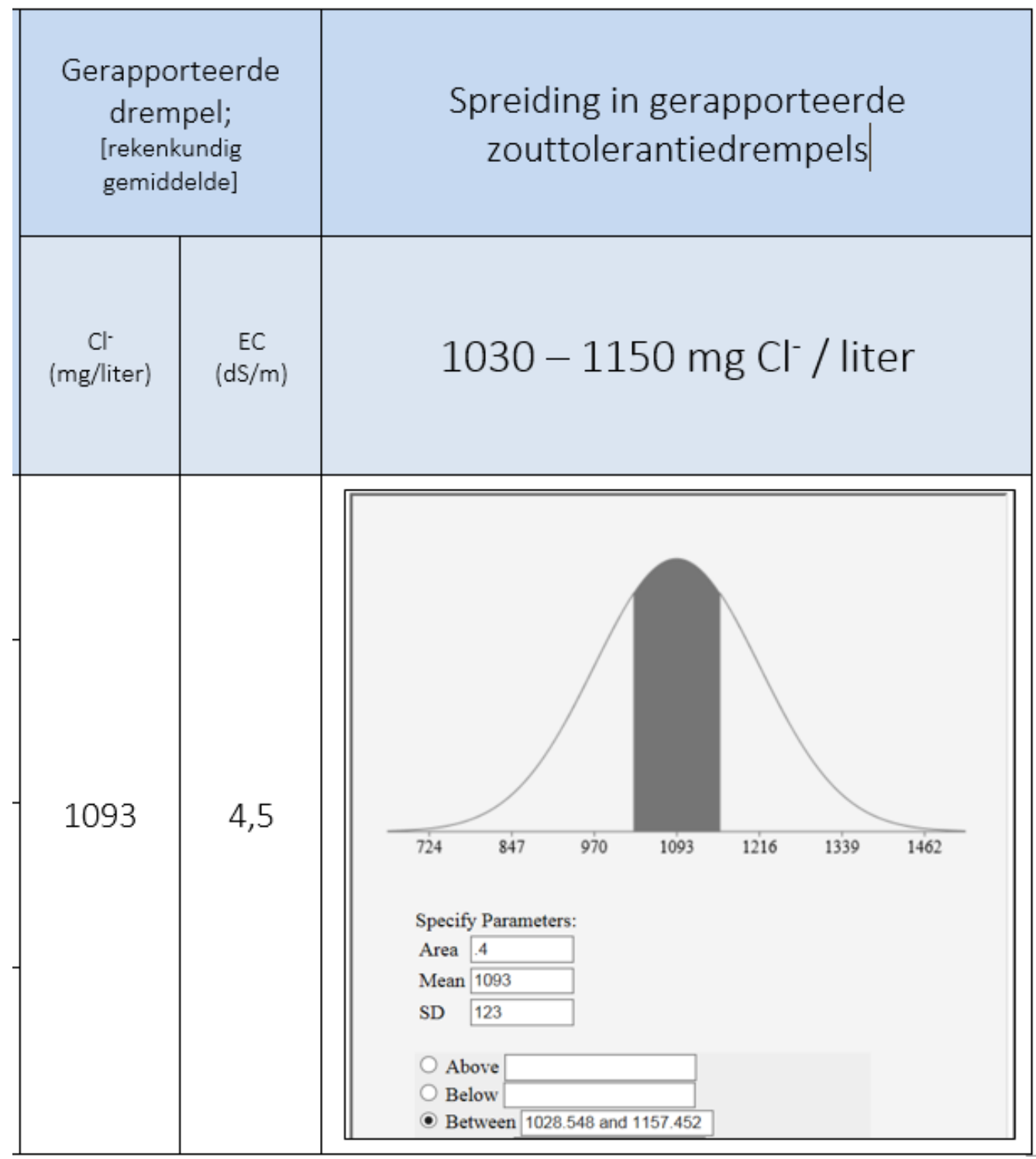




\subsection{Ui, andijvie, knolselderij, prei, wortelen, witlof}

\section{A. Literatuur}

Rhoades et al. (1992) melden in 1992 een waarde van $300 \mathrm{mg} / \mathrm{l} \mathrm{Cl}$ wat neerkomt op gevoelig tot matig gevoelig voor deze gewasgroep.

In 1983 wordt in ICW Nota 1461 (P.C. Jansen) $300 \mathrm{mg} / \mathrm{l} \mathrm{Cl}$ vermeld voor het toelaatbare chloride gehalte in het oppervlaktewater voor bouwland.

Shannon \& Grieve (1999) publiceren een grafiek met drempelwaarden voor zouttoleranties voor diverse gewassen in deze gewasgroep. De vermelde waarde van circa $950 \mathrm{mg} / \mathrm{l} \mathrm{Cl}$ in deze tabel geldt voor asperge. ondanks gerichte navraag

Eurofins (2015a) categoriseert knolselderij en prei als matig gevoelige vollegrondsgroente, met een zouttolerantiedrempel tussen 600 en $900 \mathrm{mg} \mathrm{Cl} / \mathrm{l}$; voor asperge wordt de drempel 1,5 mS/cm $( \pm 250 \mathrm{mg} \mathrm{Cl} / \mathrm{l})$ gespecificeerd (Eurofins, 2015e). De bron(nen) van de in deze informatiebladen gespecificeerde drempelwaarde(n) zouttolerantie in beregeningswater konden - - niet worden achterhaald.

Het Zilt Proefbedrijf op Texel meldt via een persoonlijke mededeling van A. de Vos een zoutdrempel voor waspeen van $2000 \mathrm{mg} / \mathrm{l}$. Deze drempel was ten tijde van de publicatie van dit rapport echter nog niet in een rapportage van het proefbedrijf onderbouwd, en wordt daarom in deze analyse niet meegenomen.

\section{Referenties}

Eurofins, 2015a. Waterkwaliteit in de akkerbouw. Bijlage/Toelichting. Eurofins Agro Laboratories, Wageningen.

Eurofins, 2015e. Waterkwaliteit in de groenteteelt vollegrond. Bijlage/Toelichting. Eurofins Agro Laboratories, Wageningen.

Jansen, P.C., 1983. Waterkwaliteit. Een beknopt overzicht van begrippen, parameters, typering en normen. Instituut voor Cultuurtechniek en Waterhuishouding, ICW-Nota 1461, Wageningen. pp. 26-28.

Rhoades, J.D., A. Kandiah and A.M. Mashali, 1992. The use of saline waters for crop production. FAO irrigation and drainage paper 48; fao.org/docrep/T0667E/T0667E00.htm

Shannon, M.C. \& C.M. Grieve, 1999. Tolerance of vegetable crops to salinity. Scientia Horticulturae 78: 5-38. 


\section{B. Gegevens}

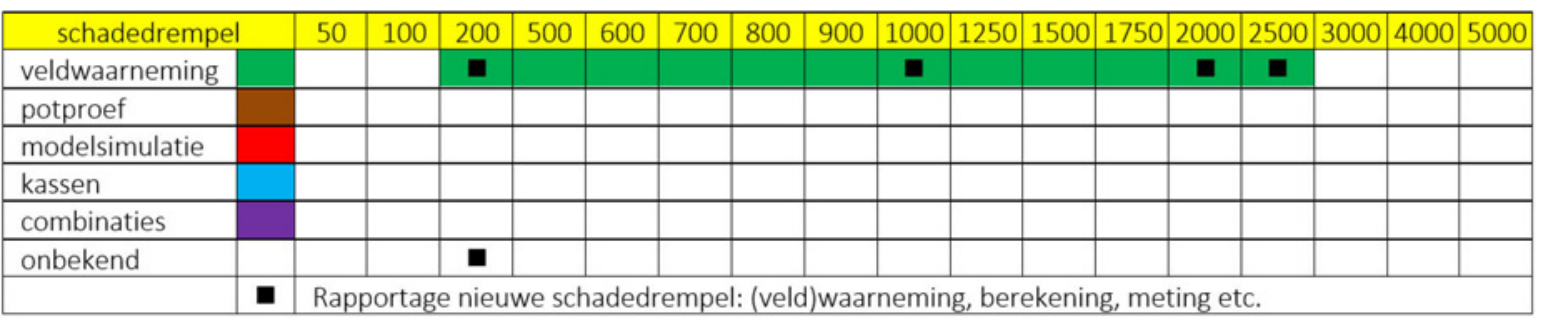

\begin{tabular}{|c|c|c|c|c|c|c|c|c|c|c|c|c|c|c|c|c|c|c|}
\hline jaar & & 1935 & 1940 & 1945 & 1950 & 1955 & 1960 & 1965 & 1970 & 1975 & 1980 & 1985 & 1990 & 1995 & 2000 & 2005 & 2010 & 2015 \\
\hline veldwaarneming & & & & & & & ㅁ & & & 口 & & & & & 口 & & & 口 \\
\hline potproef & & & & & & & & & & & & & & & & & & \\
\hline modelsimulatie & & & & & & & & & & & & & & & & & & \\
\hline kassen & & & & & & & & & & & & & & & & & & \\
\hline combinaties & & & & & & & & & & & & & & & & & & \\
\hline onbekend & & & & & & & & & & & & a & & & & & & \\
\hline
\end{tabular}

\begin{tabular}{|c|c|c|c|c|c|c|c|c|c|c|c|c|c|c|c|}
\hline No & Gewas(groep) & 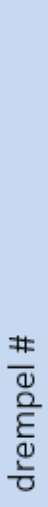 & $\begin{array}{l}\frac{1}{\pi} \\
. \mathbb{0} \\
.\end{array}$ & 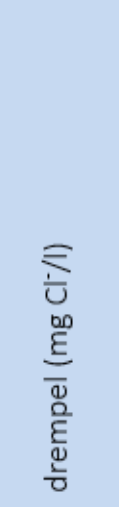 & 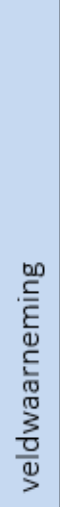 & 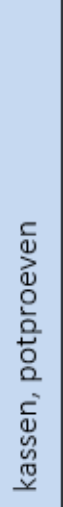 & 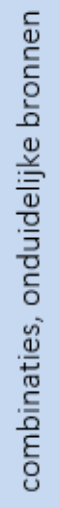 & 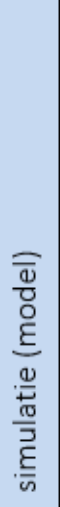 & $\begin{array}{l}\text { D } \\
\underset{N}{N} \\
\text { N }\end{array}$ & 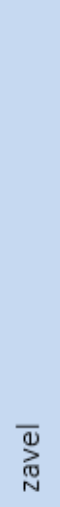 & $\frac{\bar{\alpha}}{\underline{\underline{\alpha}}}$ & 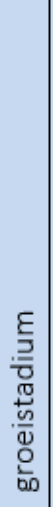 & 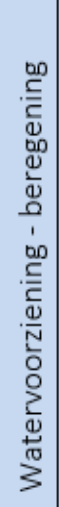 & 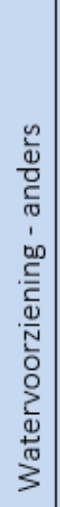 & 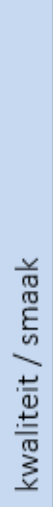 \\
\hline \multirow{4}{*}{7} & \multirow{4}{*}{$\begin{array}{l}\text { Ui, andijvie, } \\
\text { knolselderij, } \\
\text { prei, } \\
\text { wortelen, } \\
\text { witlof }\end{array}$} & 1 & 1962 & 2300 & $x$ & & & & & & & & & & \\
\hline & & 2 & 1976 & 300 & $\times$ & & & & & & & & & & \\
\hline & & 3 & 1983 & 300 & $x$ & & & & & & & & & & \\
\hline & & 4 & 1999 & 950 & $x$ & & & & & & & & & & \\
\hline
\end{tabular}



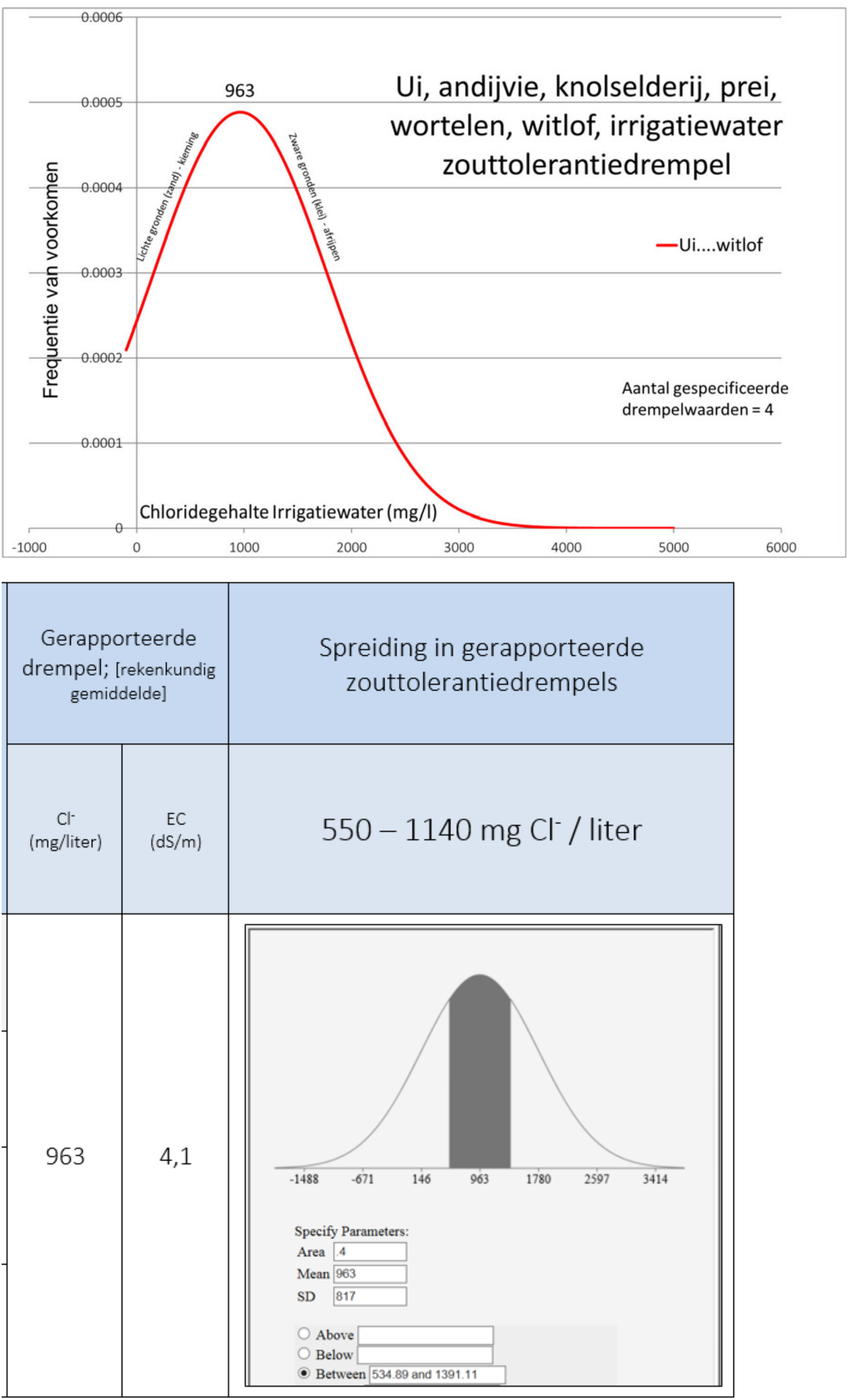


\subsection{Aubergine, aardbei, tuinbonen}

\section{A. Literatuur}

In de publicatie Waterkwaliteit en Landbouwproductie (Huinink, 1987) in het Blad Ad Fundum, worden zouttolerantiedrempels voor deze gewasgroep gerapporteerd in elektrisch geleidingsvermogen in $\mathrm{dS} / \mathrm{m}$. Omgerekend naar $\mathrm{mg} \mathrm{Cl} / \mathrm{l}$ komen de waarden overeen met $300 \mathrm{mg} \mathrm{Cl} / \mathrm{I}$ uit ICW Nota 1461 van P.C. Jansen (1983) voor vollegrondstuinbouw.

In haar richtlijn voor 'Waterkwaliteit in de akkerbouw' specificeert Eurofins (2015a) voor vele akkerbouw- en vollegrondsgroenten 'schadedrempeltrajecten' voor beregeningswater, waaronder aardbeien: $300-600 \mathrm{mg} \mathrm{Cl} / \mathrm{I}$. In een andere richtlijn adviseert Eurofins (2015e) voor 'aardbeien normale teelt' een zouttolerantiedrempel van $1,5 \mathrm{mS} / \mathrm{cm}( \pm 250 \mathrm{mg} \mathrm{Cl} / \mathrm{l})$, en voor 'aardbeien gekoelde en verlate teelt' $0,5 \mathrm{mS} / \mathrm{cm}( \pm 60 \mathrm{mg} \mathrm{Cl} / \mathrm{l})$. De bron(nen) van de door Eurofins in haar informatiebladen gespecificeerde grenswaarde $(n)$ voor zouttolerantiedrempels voor beregeningswater konden - ondanks gerichte navraag - niet worden achterhaald.

\section{Referenties}

Eurofins, 2015a. Waterkwaliteit in de akkerbouw. Bijlage/Toelichting. Eurofins Agro Laboratories, Wageningen.

Eurofins, 2015e. Waterkwaliteit in de groenteteelt vollegrond. Bijlage/Toelichting. Eurofins Agro Laboratories, Wageningen.

Jansen, P.C., 1983. Waterkwaliteit. Een beknopt overzicht van begrippen, parameters, typering en normen. Instituut voor Cultuurtechniek en Waterhuishouding, ICW-Nota 1461, Wageningen. pp. 26-28. 
C. Interpretatie
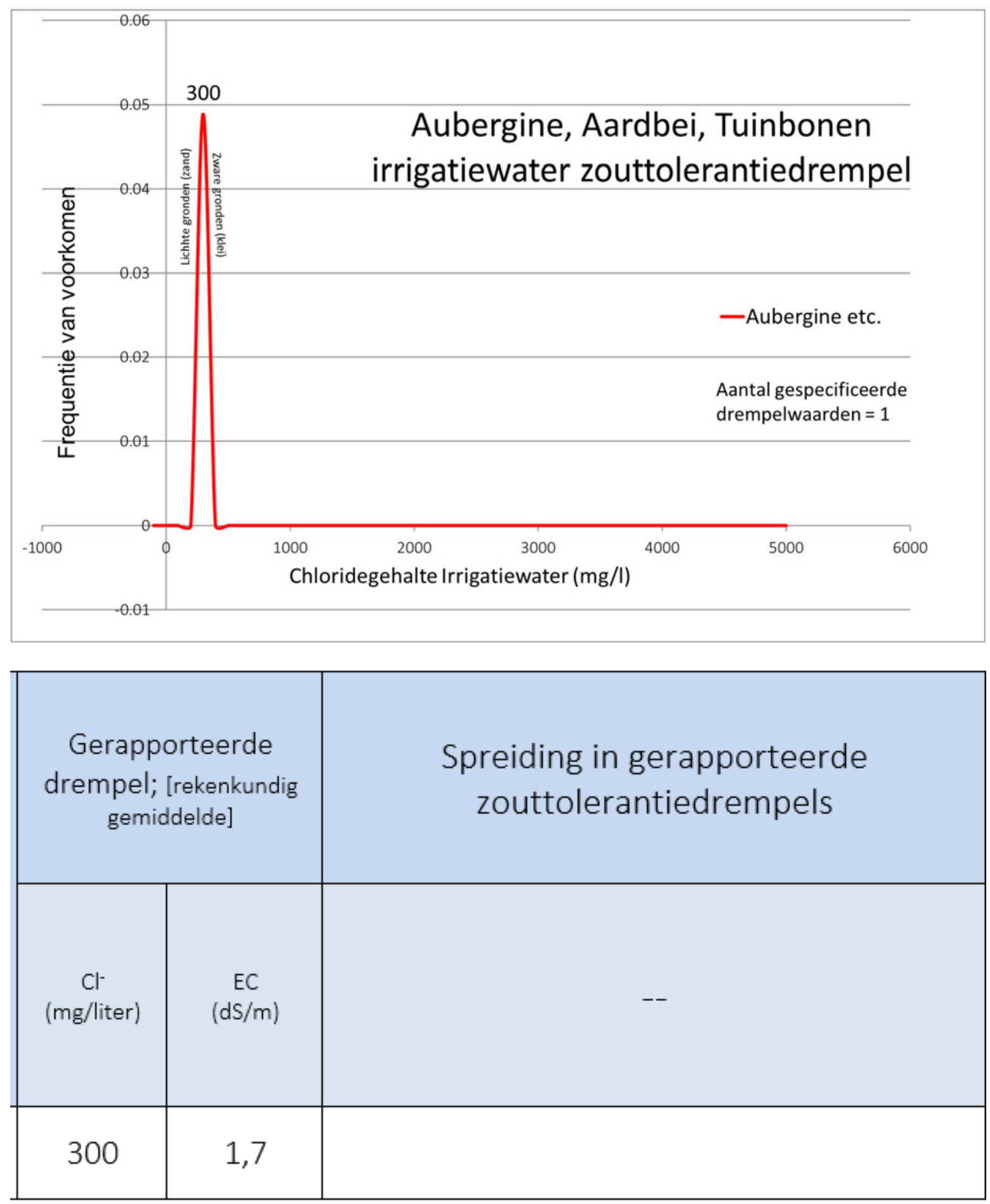


\subsection{Aardappel}

\section{A. Literatuur}

In de zeekleigebieden wordt vrij veel beregend bij de teelt van aardappelen. Uit onderzoek is gebleken dat bij een $\mathrm{Cl}$-gehalte van het sproeiwater van 500 en $1000 \mathrm{mg}$ per liter de schade niet groot is, mits men het water in kleine giften per keer toedient en de grond niet sterk laat uitdrogen (Hellings 1971). In 1983 wordt in ICW Nota 1461 (P.C. Jansen) 600 mg/l vermeld voor het toelaatbare chloride gehalte voor aardappelen.

Uit het literatuuronderzoek "Actualisering Zouttolerantie", uitgevoerd door Roest et al. (2003) dat werd uitgevoerd ten behoeve van de ontwikkeling en het gebruik van het RIZA-instrumentarium is een waarde voor het $10 \%$ gevoeligste gewas afgeleid, i.e. $200 \mathrm{mg} / \mathrm{l} \mathrm{Cl}$ voor de categorie aardappelen. In 2009 werd de studie "Review of crop salt tolerance in the Netherlands" uitgevoerd. In dit project werden met behulp van het computermodel SWAP (Wageningen UR-Alterra) de volgende drempelwaarden voor $0 \%$ gewasschade bij aardappelen op drie verschillende bodems in het droogste jaar 1976 afgeleid: $200 \mathrm{mg} / \mathrm{l} \mathrm{Cl}$ voor zandgrond, $450 \mathrm{mg} / \mathrm{l}$ voor zavelgrond en $250 \mathrm{mg} / \mathrm{l}$ voor kleigrond (Alterra-rapport 1926).

In Alterra rapport 2201 "Actualisering Zouttolerantie" (Bakel en Stuyt, 2011) is de tabel "Risico op zoutschade aan landbouwgewassen bij verschillende zoutgehalten van beregeningswater" beschikbaar gesteld door DLV Plant, welke door hen gebruikt wordt bij advisering. Ook is in dit rapport een tabel met zouttolerantiewaarden opgenomen uit het PAGV-handboek (Proefstation voor de akkerbouw en de groetenteelt in de volle grond). Voor aardappelen worden in deze tabellen de volgende waarden gehanteerd:
Bij lage tolerantie:
Bron: DLV, 1070 mg CL/l
Bij hoge tolerantie:
Bron: DLV, $1200 \mathrm{mg} \mathrm{CL/l}$
Bij lage tolerantie:
Bron: PAGV,
$600 \mathrm{mg} \mathrm{CL/l}$
Bij hoge tolerantie:
Bron: PAGV,
900 mg CL/I

Eurofins (2015a) categoriseert aardappel als matig gevoelig akkerbouwgewas, met een zouttolerantiedrempel tussen 600 en $900 \mathrm{mg} \mathrm{Cl} / \mathrm{l}$. De bron(nen) van de in dit informatieblad gespecificeerde drempelwaarde( $n$ ) zouttolerantie in beregeningswater konden - ondanks gerichte navraag - niet worden achterhaald.

Het Zilt Proefbedrijf Texel meldt sinds 2013 een zouttolerantie voor aardappel gelijk aan, of groter dan $2500 \mathrm{mg} / \mathrm{l}$. Deze drempel was ten tijde van de publicatie van dit rapport echter nog niet in een rapportage van het proefbedrijf onderbouwd, en wordt daarom in deze analyse niet meegenomen

\section{Referenties}

Bakel P.J.T., R.A.L. Kselik, C.W.J. Roest en A.A.M.F.R. Smit. 2009. Review of crop salt tolerance in the Netherlands. Rapport 1926, Alterra, Wageningen.

Bakel, P.J.T. van en L.C.P.M. Stuyt, 2011. Actualisering van de kennis van de zouttolerantie van landbouwgewassen, op basis van literatuuronderzoek, expertkennis en praktische ervaringen. Wageningen, Alterra-rapport 2201.

Eurofins, 2015a. Waterkwaliteit in de akkerbouw. Bijlage/Toelichting. Eurofins Agro Laboratories, Wageningen.

Hellings, A.J., 1971. Eisen inzake de kwaliteit van sproeiwater voor vollegrondsgroentegewassen. Mededeling 65. Bedrijfsontwikkeling 2: 4 april, editie tuinbouw, Proefstation voor de groenteteelt in de vollegrond in Nederland. p 31-37.

Jansen, P.C., 1983. Waterkwaliteit. Een beknopt overzicht van begrippen, parameters, typering en normen. Instituut voor Cultuurtechniek en Waterhuishouding, ICW-Nota 1461, Wageningen. pp. 26-28.

Roest, C.W.J., P.J.T. van Bakel \&, A.A.M.F.R. Smit, 2003. Actualisering van de zouttolerantie van landen tuinbouwgewassen ten behoeve van de berekening van de zoutschade in Nederland met het RIZA-instrumentarium. Memo Alterra, Wageningen, $16 \mathrm{p}$. 


\section{B. Gegevens}

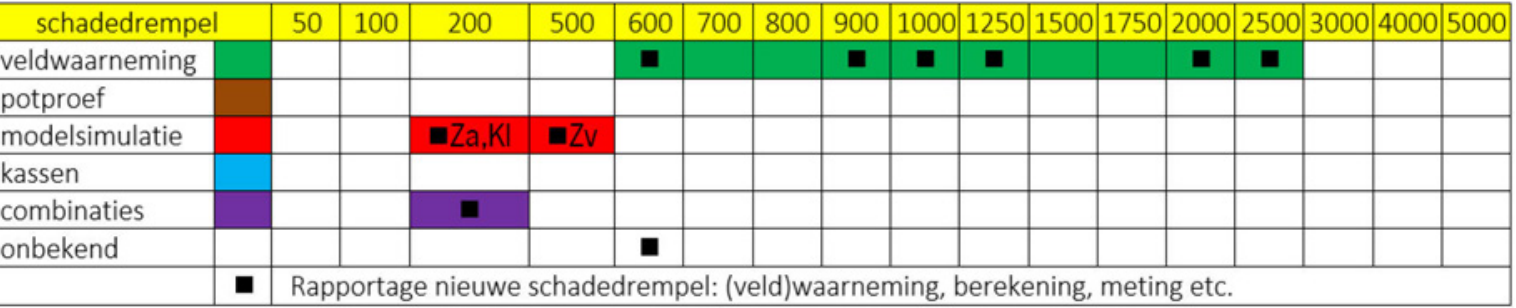

\begin{tabular}{|c|c|c|c|c|c|c|c|c|c|c|c|c|c|c|c|c|c|c|}
\hline jaar & & 1935 & 1940 & 1945 & 1950 & 1955 & 1960 & 1965 & 1970 & 1975 & 1980 & 1985 & 1990 & 1995 & 2000 & 2005 & 2010 & 2015 \\
\hline veldwaarneming & & & & & & & & 口 & a & & & & & & & & a & 口 \\
\hline potproef & & & & & & & & & & & & & & & & & & \\
\hline kassen & & & & & & & & & & & & & & & & & & \\
\hline combinaties & & & & & & & & & & & & & & & & 무 & & \\
\hline onbekend & & & & & & & & & & & & 口 & & & & & & \\
\hline
\end{tabular}

\begin{tabular}{|c|c|c|c|c|c|c|c|c|c|c|c|c|c|c|c|}
\hline No & Gewas(groep) & 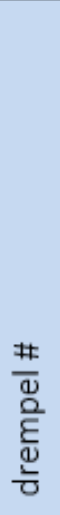 & 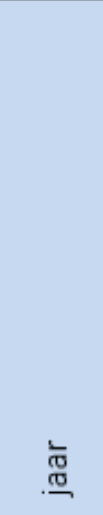 & 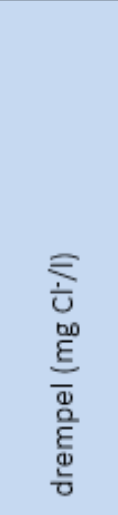 & 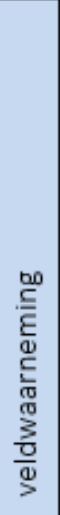 & 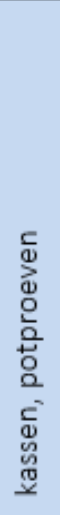 & 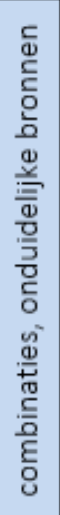 & 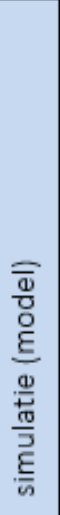 & $\begin{array}{l}\text { ס } \\
\text { त् } \\
\text { N }\end{array}$ & 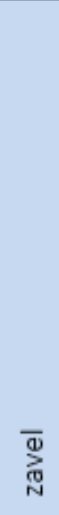 & $\frac{\bar{\omega}}{\underline{\underline{\omega}}}$ & 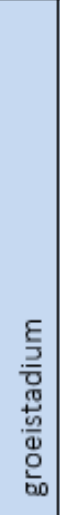 & 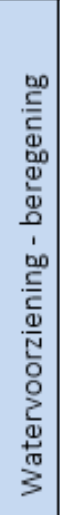 & 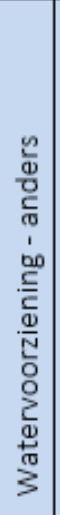 & 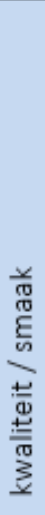 \\
\hline \multirow{15}{*}{9} & \multirow{15}{*}{ Aardappelen } & 1 & 1968 & 1000 & $x$ & & & & & & $x$ & & $x$ & & \\
\hline & & 2 & 1983 & 600 & $x$ & & & & & & & & & & \\
\hline & & 3 & 2003 & 202 & & & $x$ & & & & & & $x$ & & \\
\hline & & 4 & 2003 & 202 & & & $x$ & & & & & & $x$ & & \\
\hline & & 5 & 2003 & 200 & & & $x$ & & & & & & $x$ & & \\
\hline & & 6 & 2009 & 200 & & & & $x$ & $x$ & & & & & & \\
\hline & & 7 & 2009 & 250 & & & & $x$ & & & $x$ & & & & \\
\hline & & 8 & 2009 & 450 & & & & $x$ & & $x$ & & & & & \\
\hline & & 9 & 2011 & 1200 & $x$ & & & & & & & & $x$ & & \\
\hline & & 10 & 2015 & 1070 & $x$ & & & & & & & & $x$ & & \\
\hline & & 11 & 2015 & 1200 & $x$ & & & & & & & & $x$ & & \\
\hline & & 12 & 2015 & 600 & $x$ & & & & & & & & $x$ & & \\
\hline & & 13 & 2015 & 900 & $x$ & & & & & & & & $x$ & & \\
\hline & & 14 & 2015 & 2500 & $x$ & & & & & & & & $x$ & & \\
\hline & & 15 & 2015 & 2000 & $x$ & & & & & & & & $x$ & & \\
\hline
\end{tabular}


C. Interpretatie
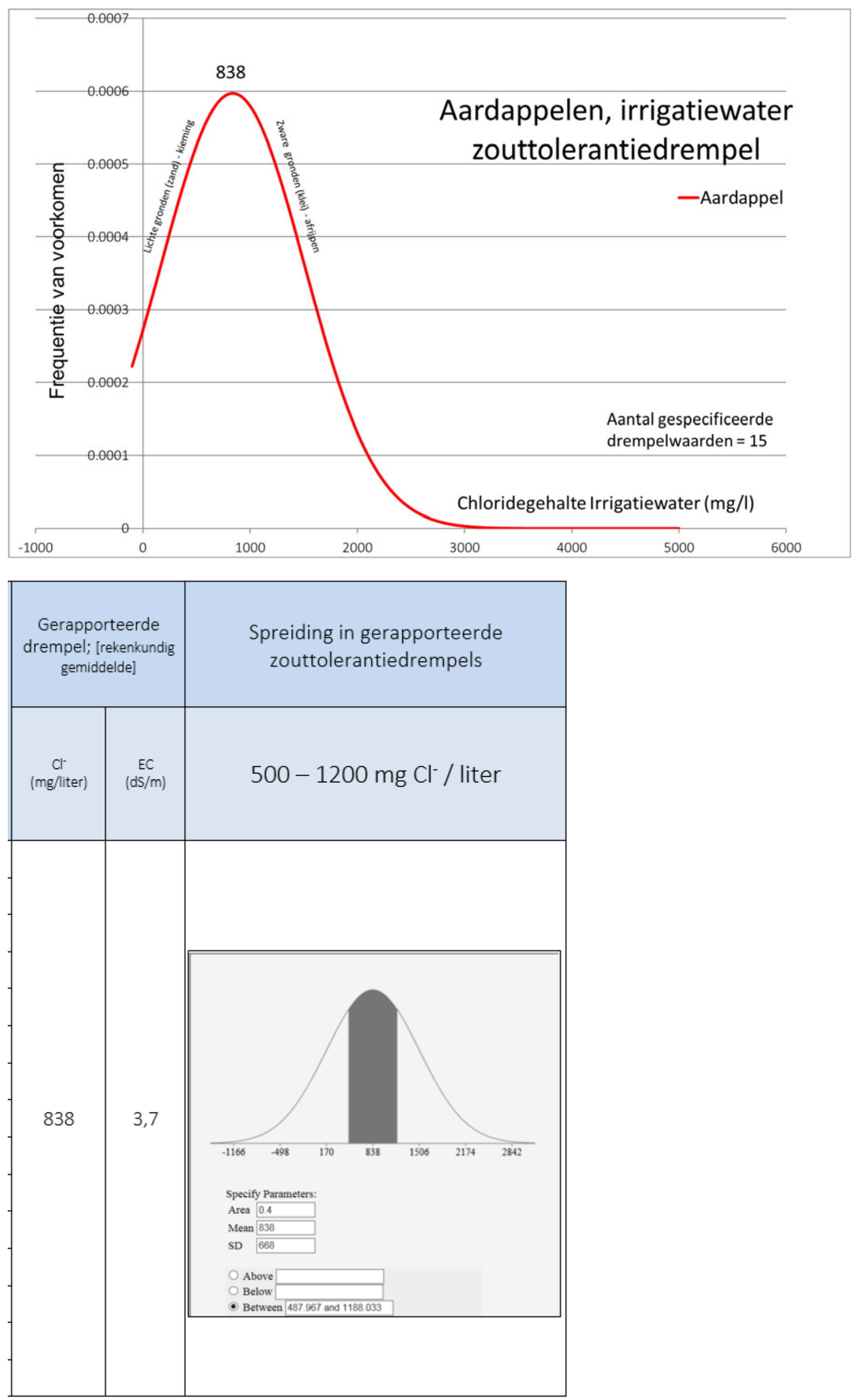


\subsection{Augurk}
A. Literatuur gehanteerd:

$\begin{array}{lll}\text { Bij lage tolerantie: } & \text { Bron: DLV, } & 340 \mathrm{mg} \mathrm{CL} / \mathrm{l} \\ \text { Bij hoge tolerantie: } & \text { Bron: DLV, } & 500 \mathrm{mg} \mathrm{CL} / \mathrm{I} \\ \text { Bij lage tolerantie: } & \text { Bron: PAGV, } & 300 \mathrm{mg} \mathrm{CL/l} \\ \text { Bij hoge tolerantie: } & \text { Bron: PAGV, } & 600 \mathrm{mg} \mathrm{CL/I}\end{array}$

In Alterra rapport 2201 "Actualisering Zouttolerantie" (Bakel en Stuyt, 2011) is de tabel "Risico op zoutschade aan landbouwgewassen bij verschillende zoutgehalten van beregeningswater" beschikbaar gesteld door DLV Plant, die door hen voor advisering wordt gebruikt. Ook is in dit rapport een tabel met zouttolerantiewaarden opgenomen uit het PAGV-handboek (Proefstation voor de akkerbouw en de groetenteelt in de volle grond). Voor augurken worden in deze tabellen de volgende waarden

Augurk wordt genoemd in informatiebladen met richtlijnen voor waterkwaliteit, uitgegeven door Eurofins (2015a en -e). De bron(nen) van de in deze informatiebladen gespecificeerde grenswaarde(n) konden - ondanks gerichte navraag - niet worden achterhaald.

\section{Referenties}

Bakel, P.J.T. van en L.C.P.M. Stuyt, 2011. Actualisering van de kennis van de zouttolerantie van landbouwgewassen, op basis van literatuuronderzoek, expertkennis en praktische ervaringen. Wageningen, Alterra-rapport 2201.

Eurofins, 2015a. Waterkwaliteit in de akkerbouw. Bijlage/Toelichting. Eurofins Agro Laboratories, Wageningen.

Eurofins, 2015e. Waterkwaliteit in de groenteteelt vollegrond. Bijlage/Toelichting. Eurofins Agro Laboratories, Wageningen. 
C. Interpretatie
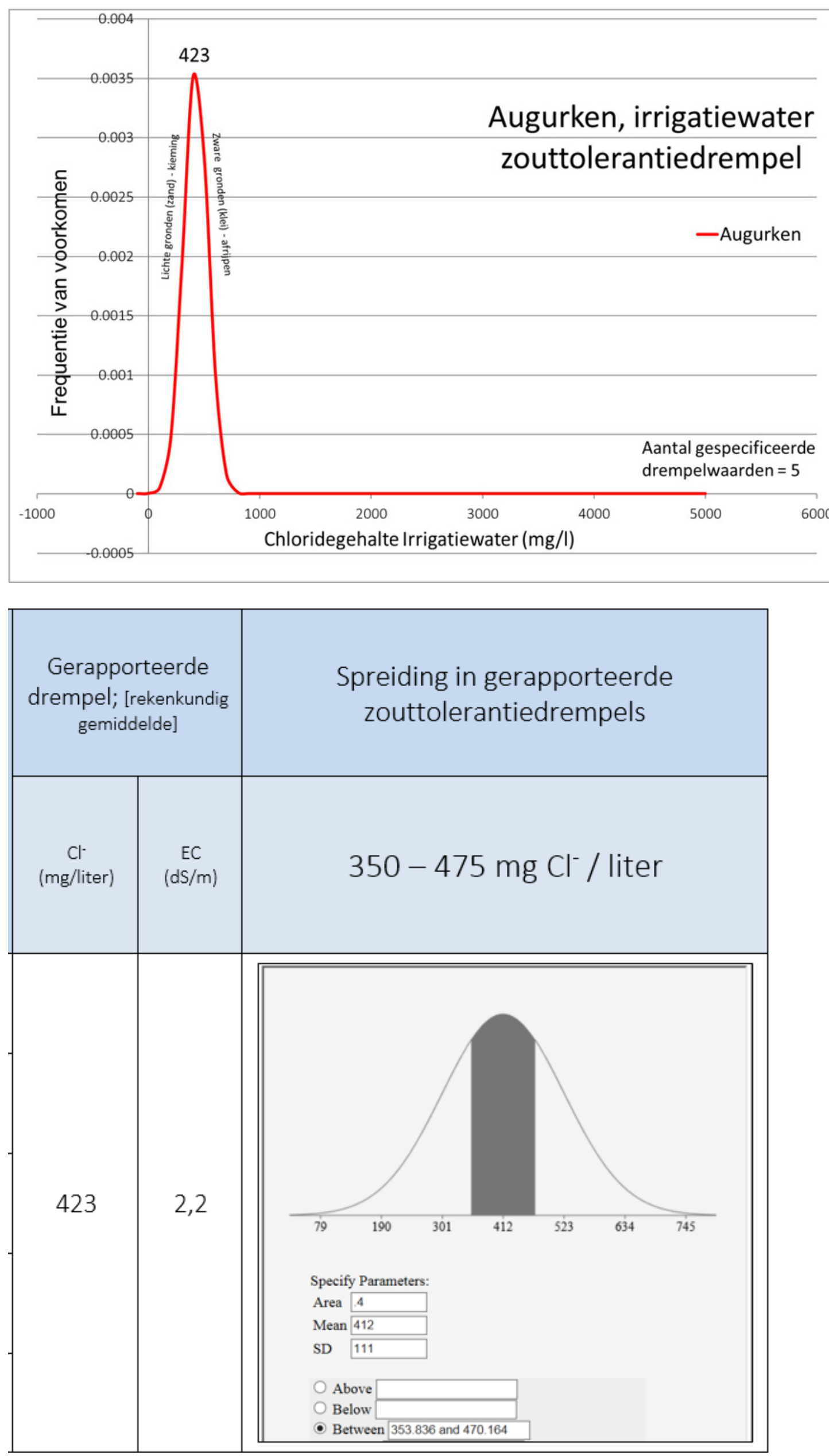


\subsection{Broccoli}

\section{A. Literatuur}

Shannon \& Grieve (1999) publiceren drempelwaarden voor zouttoleranties voor diverse gewassen, uitgedrukt in dS/m. In de gewasgroep 'Broccoli' vermelden ze een waarde van $600 \mathrm{mg} / \mathrm{l} \mathrm{Cl}$.

\section{Referenties}

Shannon, M.C. \& C.M. Grieve, 1999. Tolerance of vegetable crops to salinity. Scientia Horticulturae 78: 5-38.

\section{B. Gegevens}

\begin{tabular}{|c|c|c|c|c|c|c|c|c|c|c|c|c|c|c|c|c|c|c|}
\hline schadedrempel & & 50 & 100 & 200 & 500 & 600 & 700 & 800 & 900 & 1000 & 1250 & 1500 & 1750 & 2000 & 2500 & 3000 & 4000 & 5000 \\
\hline veldwaarneming & & & & & & 口 & & & & & & & & & & & & \\
\hline potproef & & & & & & & & & & & & & & & & & & \\
\hline modelsimulatie & & & & & & & & & & & & & & & & & & \\
\hline kassen & & & & & & & & & & & & & & & & & & \\
\hline combinaties & & & & & & & & & & & & & & & & & & \\
\hline onbekend & & & & & & & & & & & & & & & & & & \\
\hline & 口 & Rapp & orta & e nies & we sc & ladedr & empel & : (veld & waar & neming & ig, bere & ekening & g, met & ting etc & & & & \\
\hline
\end{tabular}

\begin{tabular}{|c|c|c|c|c|c|c|c|c|c|c|c|c|c|c|c|c|c|c|}
\hline jaar & & 1935 & 1940 & 1945 & 1950 & 1955 & 1960 & 1965 & 1970 & 1975 & 1980 & 1985 & 1990 & 1995 & 2000 & 2005 & 2010 & 2015 \\
\hline veldwaarneming & & & & & & & & & & & & & & & " & & & \\
\hline potproef & & & & & & & & & & & & & & & & & & \\
\hline modelsimulatie & & & & & & & & & & & & & & & & & & \\
\hline kassen & & & & & & & & & & & & & & & & & & \\
\hline combinaties & & & & & & & & & & & & & & & & & & \\
\hline onbekend & & & & & & & & & & & & & & & & & & \\
\hline
\end{tabular}

\begin{tabular}{|c|c|c|c|c|c|c|c|c|c|c|c|c|c|c|c|}
\hline No & Gewas(groep) & 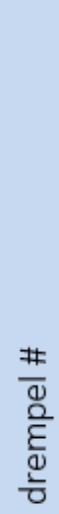 & 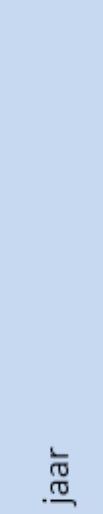 & 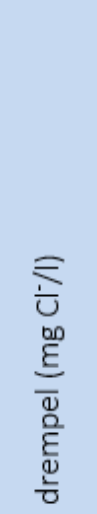 & 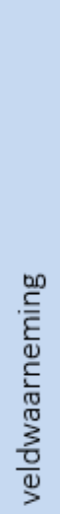 & 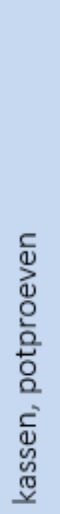 & 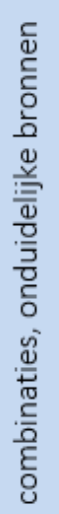 & 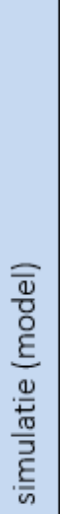 & 胥 & $\begin{array}{l}\bar{D} \\
\overbrace{N}^{D} \\
N\end{array}$ & $\frac{\bar{\omega}}{\underline{x}}$ & 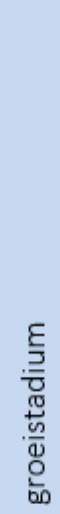 & $\begin{array}{l}0 \\
0 \\
0 \\
0 \\
0 \\
0 \\
0 \\
0 \\
0 \\
0 \\
0 \\
0 \\
0 \\
0 \\
0 \\
0 \\
0 \\
0 \\
0 \\
0 \\
0 \\
0 \\
3\end{array}$ & 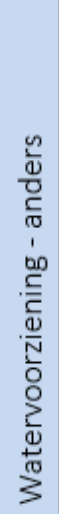 & 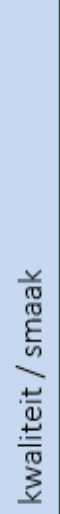 \\
\hline 11 & Broccoli & 1 & 1999 & 600 & $x$ & & & & & & & & $x$ & & \\
\hline
\end{tabular}


C. Interpretatie

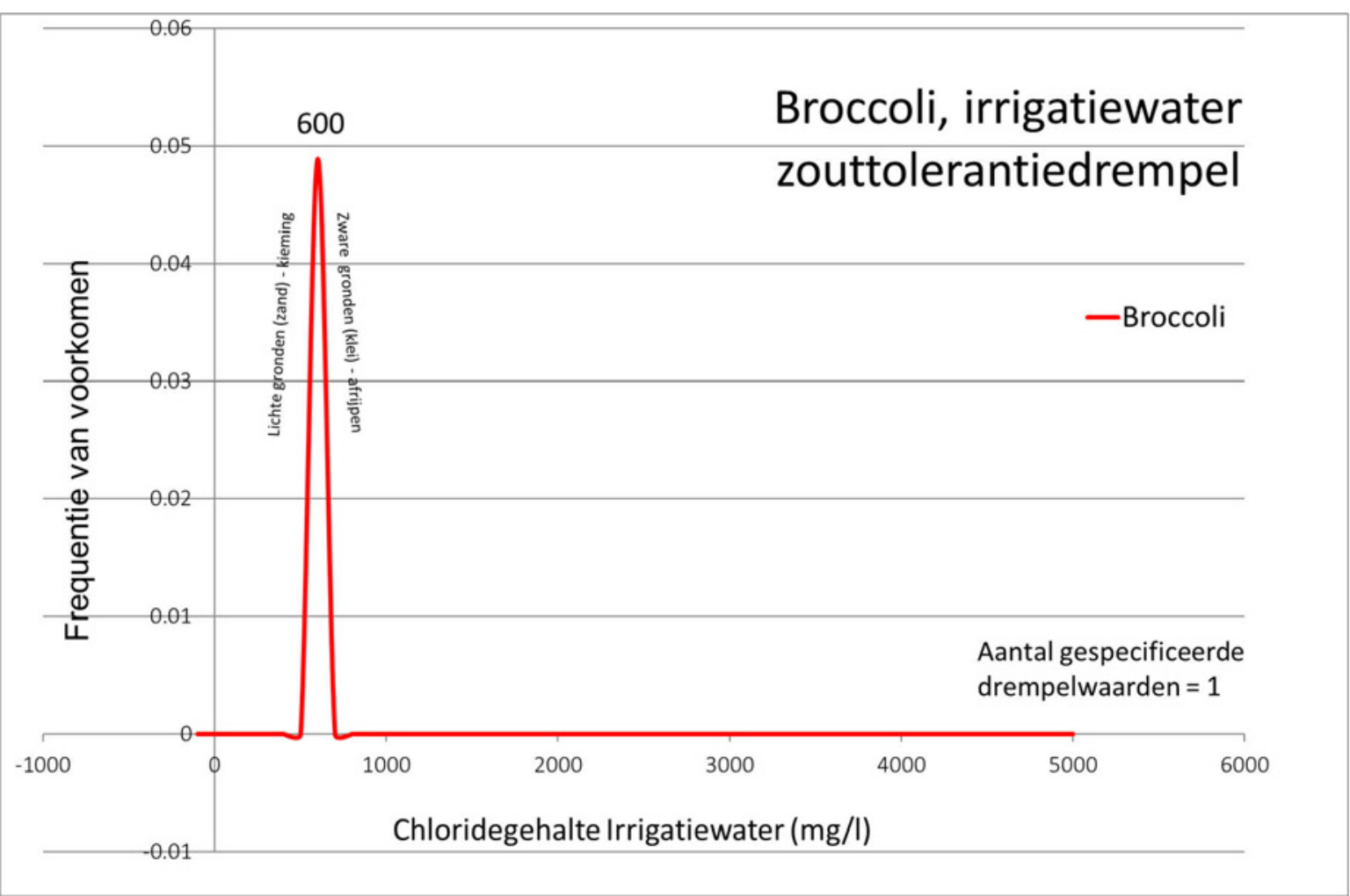

\begin{tabular}{|c|c|c|}
\hline \multicolumn{2}{|c|}{$\begin{array}{c}\text { Gerapporteerde } \\
\text { drempel; [rekenkundig } \\
\text { gemiddelde] }\end{array}$} & $\begin{array}{c}\text { Spreiding in gerapporteerde } \\
\text { zouttolerantiedrempels }\end{array}$ \\
\hline $\begin{array}{c}\mathrm{Cl} \\
(\mathrm{mg} / \text { liter })\end{array}$ & $\begin{array}{c}\mathrm{EC} \\
(\mathrm{dS} / \mathrm{m})\end{array}$ & -- \\
\hline 600 & 2,9 & \\
\hline
\end{tabular}




\subsection{Erwten}

\section{A. Literatuur}

Couwenhoven (1971) vermeldt n.a.v. onderzoek van Zijlstra (1946) bij bevloeiing van erwten met een voedingsoplossing van $1100 \mathrm{mg} \mathrm{Cl} / \mathrm{l}$, een drogestofvermindering van $10 \%$. Omdat deze waarde tot schade leidt en sterk afwijkt van recente opgaven is hij hier genegeerd.

In Alterra rapport 2201 "Actualisering Zouttolerantie" (Bakel en Stuyt, 2011) is de tabel "Risico op zoutschade aan landbouwgewassen bij verschillende zoutgehalten van beregeningswater" beschikbaar gesteld door DLV Plant, die door hen voor advisering wordt gebruikt. Voor erwten worden in deze tabel de volgende waarden gehanteerd:

Bij lage tolerantie: Bron: DLV, $340 \mathrm{mg} \mathrm{CL/l}$

Bij hoge tolerantie: Bron: DLV, $500 \mathrm{mg} \mathrm{CL/l}$

Eurofins (2015a) noemt erwten als gevoelig akkerbouwgewas met een zouttolerantiedrempel van 600-900 mg. De bron(nen) van de in dit informatieblad gespecificeerde drempelwaarde(n) zouttolerantie in beregeningswater konden - ondanks gerichte navraag - niet worden achterhaald.

\section{Referenties}

Bakel, P.J.T. van en L.C.P.M. Stuyt, 2011. Actualisering van de kennis van de zouttolerantie van landbouwgewassen, op basis van literatuuronderzoek, expertkennis en praktische ervaringen. Wageningen, Alterra-rapport 2201.

Couwenhoven, T., 1971. De verzilting en het gebruik van sproeiwater in de akkerbouw. Bedrijfsontwikkeling 2, editie Akkerbouw. Instituut voor Cultuurtechniek en Waterhuishouding, Wageningen, p 53-63.

Eurofins, 2015a. Waterkwaliteit in de akkerbouw. Bijlage/Toelichting. Eurofins Agro Laboratories, Wageningen.

Zijlstra, K., 1946. Over de gevoeligheid van eenige landbouwgewassen voor zeewater. Verslagen van Landbouwkundige Onderzoekingen 52 (2), 25-51. 


\section{B. Gegevens}

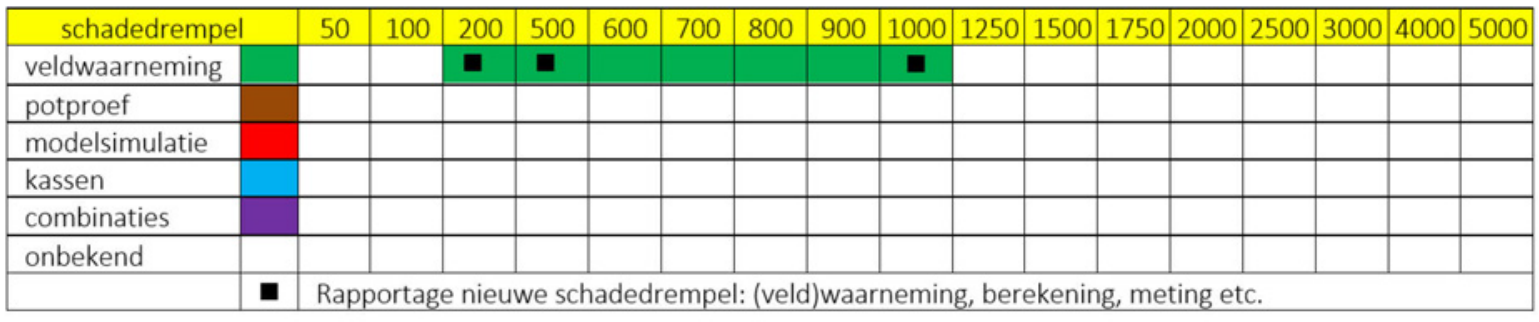

\begin{tabular}{|c|c|c|c|c|c|c|c|c|c|c|c|c|c|c|c|c|c|c|}
\hline jaar & & 1935 & 1940 & 1945 & 1950 & 1955 & 1960 & 1965 & 1970 & 1975 & 1980 & 1985 & 1990 & 1995 & 2000 & 2005 & 2010 & 2015 \\
\hline veldwaarneming & & & & & & & & & 口 & & & & & & & & & 口 \\
\hline potproef & & & & & & & & & & & & & & & & & & \\
\hline kassen & & & & & & & & & & & & & & & & & & \\
\hline combinaties & & & & & & & & & & & & & & & & & & \\
\hline onbekend & & & & & & & & & & & & & & & & & & \\
\hline
\end{tabular}

\begin{tabular}{|c|c|c|c|c|c|c|c|c|c|c|c|c|c|c|c|}
\hline No & Gewas(groep) & 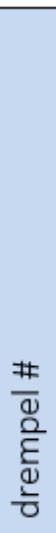 & $\begin{array}{l}\frac{i}{\pi} \\
\stackrel{\mathbb{\pi}}{\Omega}\end{array}$ & 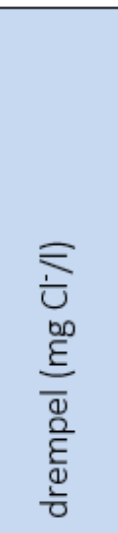 & 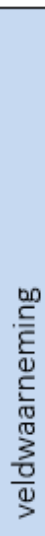 & 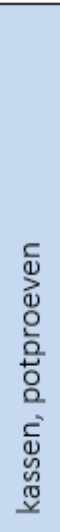 & 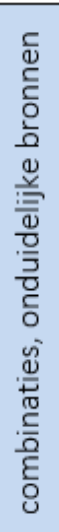 & 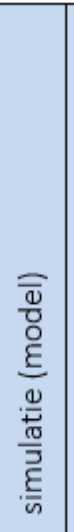 & $\begin{array}{l}\text { T⿱ } \\
\text { 足 } \\
\text { N }\end{array}$ & $\stackrel{\text { }}{\mathbb{N}}_{\bar{N}}^{\bar{D}}$ & $\frac{\bar{\omega}}{\underline{u}}$ & 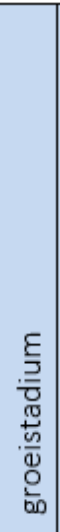 & 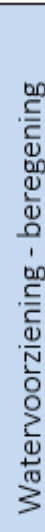 & 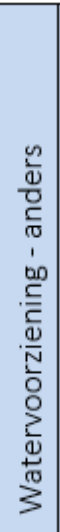 & 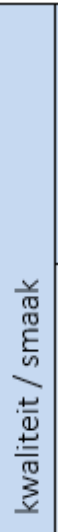 \\
\hline \multirow{3}{*}{12} & \multirow{3}{*}{ Erwten } & 1 & 1971 & 1100 & $x$ & & & & & & & & $x$ & & \\
\hline & & 2 & 2015 & 340 & $x$ & & & & & & & & $x$ & & \\
\hline & & 3 & 2015 & 500 & $x$ & & & & & & & & $x$ & & \\
\hline
\end{tabular}


C. Interpretatie
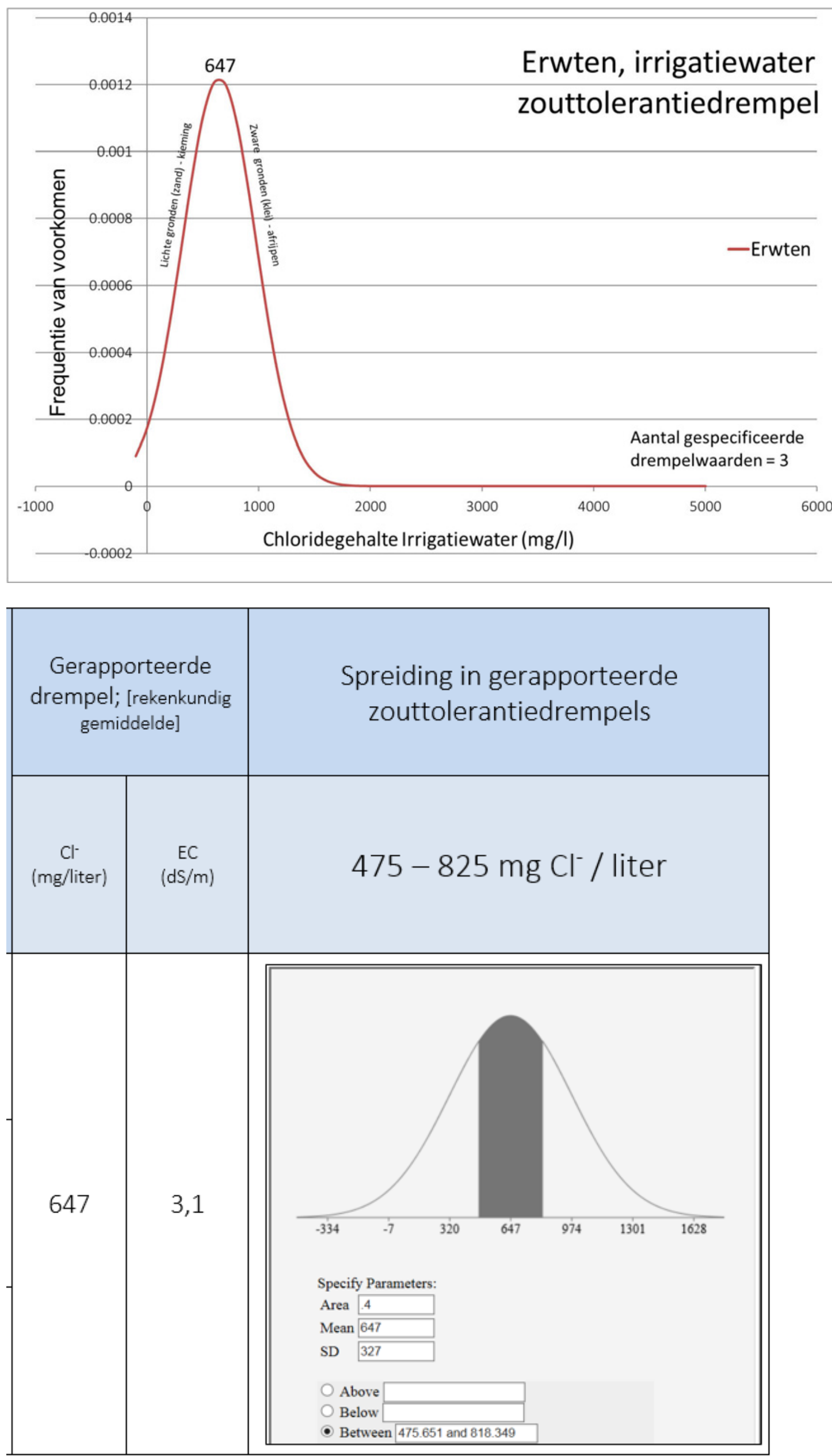


\subsection{Knolselderij}

\section{A. Literatuur}

Shannon \& Grieve (1999) hebben, voor beregeningswater, een grafiek met drempelwaarden voor zouttoleranties van diverse gewassen gepubliceerd. Voor knolselderij wordt hierin een waarde vermeld van circa $1,8 \mathrm{dS} / \mathrm{m}$, wat overeenkomt met $325 \mathrm{mg} / \mathrm{l} \mathrm{Cl}$.

In Alterra rapport 2201 "Actualisering Zouttolerantie" (Bakel en Stuyt, 2011) is de tabel "Risico op zoutschade aan landbouwgewassen bij verschillende zoutgehalten van beregeningswater" beschikbaar gesteld door DLV Plant, die door hen voor advisering wordt gebruikt. Ook is in dit rapport een tabel met zouttolerantiewaarden opgenomen uit het PAGV-handboek (Proefstation voor de akkerbouw en de groetenteelt in de volle grond). Voor knolselderij zijn in deze tabellen de volgende waarden gehanteerd:
Bij lage tolerantie:
Bron: DLV,
$900 \mathrm{mg} \mathrm{CL/l}$
Bij hoge tolerantie:
Bron: DLV,
$1070 \mathrm{mg} \mathrm{CL/}$
Bij lage tolerantie:
Bron: PAGV,
$600 \mathrm{mg} \mathrm{CL/l}$
Bij hoge tolerantie:
Bron: PAGV,
$900 \mathrm{mg} \mathrm{CL/l}$

Eurofins (2015a) categoriseert knolselderij als matig gevoelige vollegrondsgroente met een zouttolerantiedrempel van 900-1200 mg. De bron(nen) van de in dit informatieblad gespecificeerde drempelwaarde(n) zouttolerantie in beregeningswater konden - ondanks gerichte navraag - niet worden achterhaald.

\section{Referenties}

Bakel, P.J.T. van en L.C.P.M. Stuyt, 2011. Actualisering van de kennis van de zouttolerantie van landbouwgewassen, op basis van literatuuronderzoek, expertkennis en praktische ervaringen. Wageningen, Alterra-rapport 2201.

Eurofins, 2015a. Waterkwaliteit in de akkerbouw. Bijlage/Toelichting. Eurofins Agro Laboratories, Wageningen.

Shannon, M.C. \& C.M. Grieve, 1999. Tolerance of vegetable crops to salinity. Scientia Horticulturae 78: 5-38. 


\section{B. Gegevens}

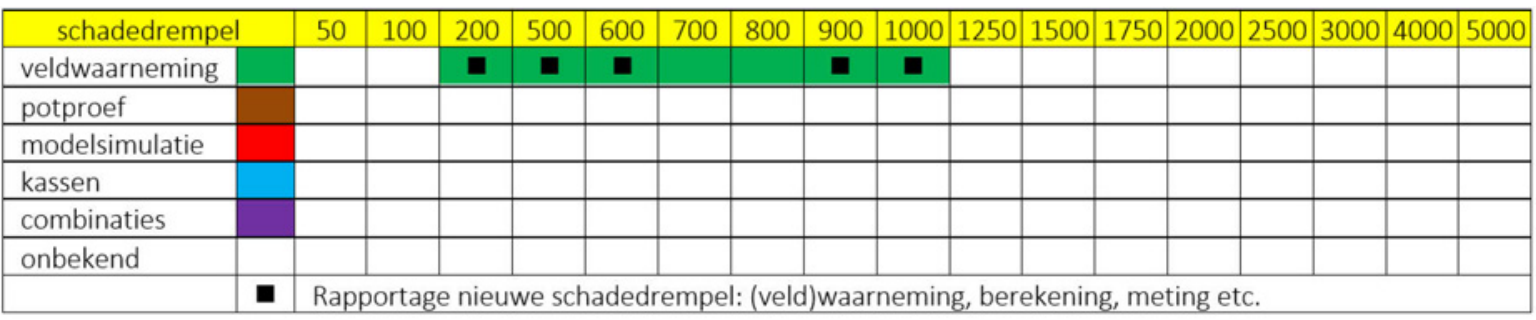

\begin{tabular}{|c|c|c|c|c|c|c|c|c|c|c|c|c|c|c|c|c|c|c|}
\hline jaar & & 1935 & 1940 & 1945 & 1950 & 1955 & 1960 & 1965 & 1970 & 1975 & 1980 & 1985 & 1990 & 1995 & 2000 & 2005 & 2010 & 2015 \\
\hline veldwaarneming & & & & & & & & & & & & & & & a & & 口 & 口 \\
\hline potproef & & & & & & & & & & & & & & & & & & \\
\hline kassen & & & & & & & & & & & & & & & & & & \\
\hline combinaties & & & & & & & & & & & & & & & & & & \\
\hline onbekend & & & & & & & & & & & & & & & & & & \\
\hline
\end{tabular}

\begin{tabular}{|c|c|c|c|c|c|c|c|c|c|c|c|c|c|c|c|}
\hline No & Gewas(groep) & 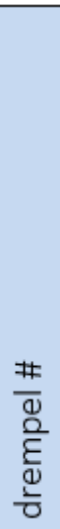 & 离 & 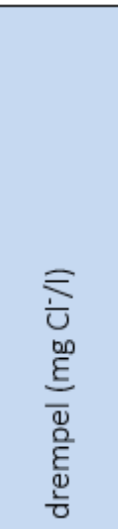 & 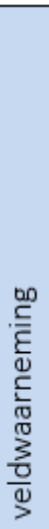 & 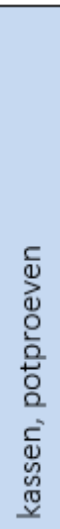 & 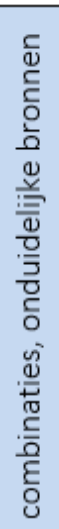 & 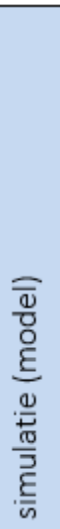 & $\underset{\substack{\mathbb{N} \\
\text { T. }}}{\text { D. }}$ & $\begin{array}{l}\bar{D} \\
\underset{N}{N}\end{array}$ & $\frac{\bar{\omega}}{\underline{\underline{y}}}$ & 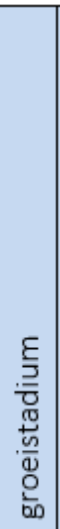 & 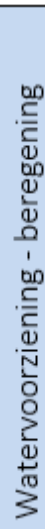 & 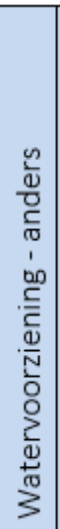 & 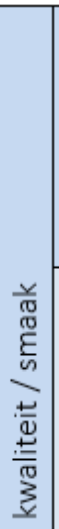 \\
\hline \multirow{6}{*}{13} & \multirow{6}{*}{ Knolselderij } & 1 & 1999 & 325 & $x$ & & & & & & & & $x$ & & \\
\hline & & 2 & 2011 & 1000 & $x$ & & & & & & & & $x$ & & \\
\hline & & 3 & 2015 & 900 & $x$ & & & & & & & & $x$ & & \\
\hline & & 4 & 2015 & 1070 & $x$ & & & & & & & & $x$ & & \\
\hline & & 5 & 2015 & 600 & $x$ & & & & & & & & $x$ & & \\
\hline & & 6 & 2015 & 900 & $x$ & & & & & & & & $x$ & & \\
\hline
\end{tabular}


C. Interpretatie

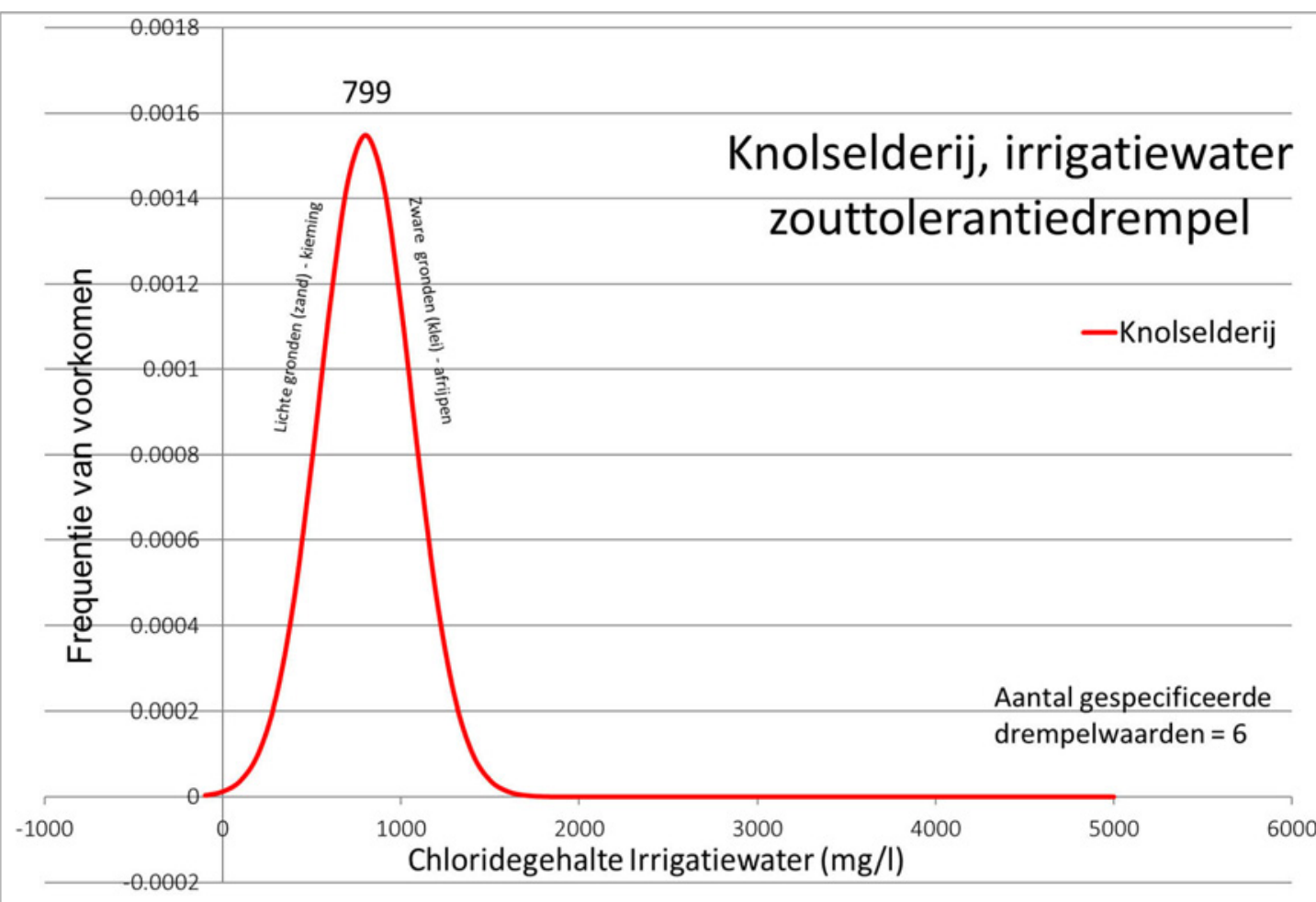

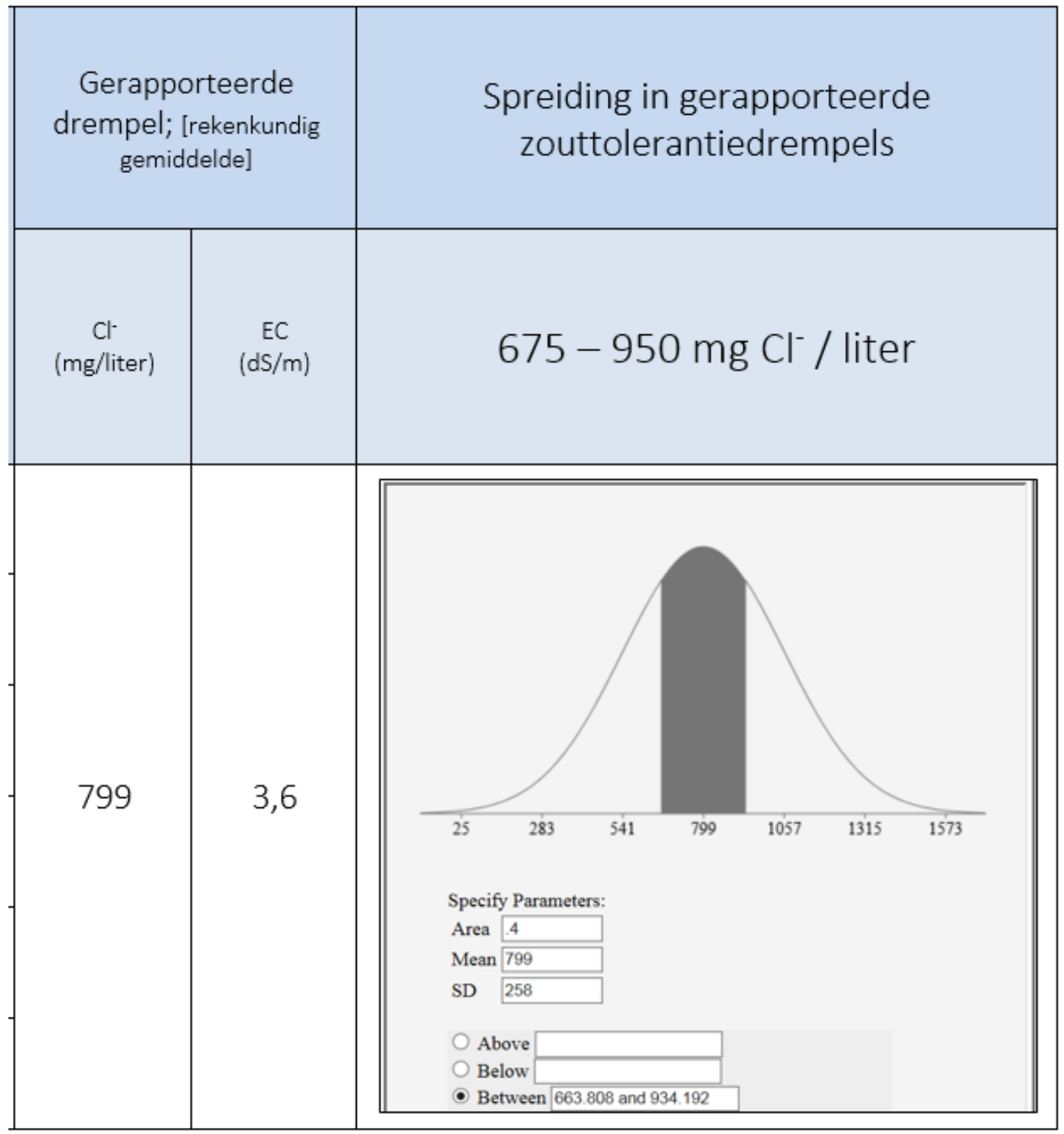




\subsection{Kroot (rode biet)}

\section{A. Literatuur}

In Alterra rapport 2201 "Actualisering Zouttolerantie" (Bakel en Stuyt, 2011) is de tabel "Risico op zoutschade aan landbouwgewassen bij verschillende zoutgehalten van beregeningswater" beschikbaar gesteld door DLV Plant, die door hen voor advisering wordt gebruikt. Ook is in dit rapport een tabel met zouttolerantiewaarden opgenomen uit het PAGV-handboek (Proefstation voor de akkerbouw en de groetenteelt in de volle grond). Voor kroot worden in deze tabellen de volgende waarden gehanteerd:
Bij lage tolerantie Bron DLV
$1070 \mathrm{mg} \mathrm{CL} / \mathrm{l}$
Bij hoge tolerantie Bron DLV
$1200 \mathrm{mg} \mathrm{CL} / \mathrm{l}$
Bij lage tolerantie Bron PAGV
$900 \mathrm{mg} \mathrm{CL} / \mathrm{l}$
Bij hoge tolerantie Bron PAGV
$1200 \mathrm{mg} \mathrm{CL} / \mathrm{l}$

\section{Referenties}

Bakel, P.J.T. van en L.C.P.M. Stuyt, 2011. Actualisering van de kennis van de zouttolerantie van landbouwgewassen, op basis van literatuuronderzoek, expertkennis en praktische ervaringen. Wageningen, Alterra-rapport 2201. 


\section{B. Gegevens}

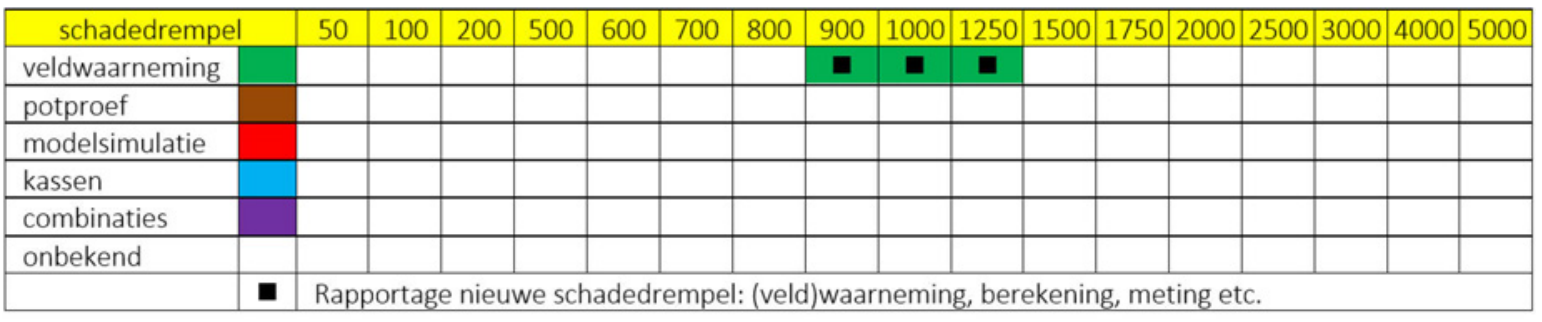

\begin{tabular}{|c|c|c|c|c|c|c|c|c|c|c|c|c|c|c|c|c|c|c|}
\hline jaar & & 1935 & 1940 & 1945 & 1950 & 1955 & 1960 & 1965 & 1970 & 1975 & 1980 & 1985 & 1990 & 1995 & 2000 & 2005 & 2010 & 2015 \\
\hline veldwaarneming & & & & & & & & & & & & & & & & & & 口 \\
\hline potproef & & & & & & & & & & & & & & & & & & \\
\hline modelsimulatie & & & & & & & & & & & & & & & & & & \\
\hline kassen & & & & & & & & & & & & & & & & & & \\
\hline combinaties & & & & & & & & & & & & & & & & & & \\
\hline onbekend & & & & & & & & & & & & & & & & & & \\
\hline & $\mathbf{a}$ & Rapp & portage & e nieuv & we sch & ladedr & empel & I: (veld & d) waari & nemin & $\mathrm{g}$, bere & ekenin & ig, met & ting et & & & & \\
\hline
\end{tabular}

\begin{tabular}{|c|c|c|c|c|c|c|c|c|c|c|c|c|c|c|c|}
\hline No & Gewas(groep) & 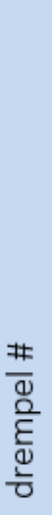 & . & 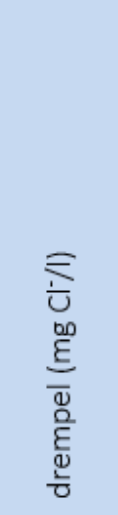 & 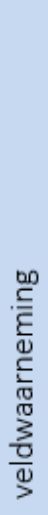 & 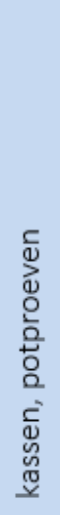 & 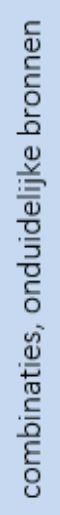 & 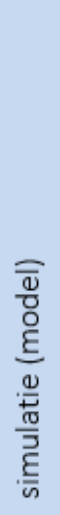 & 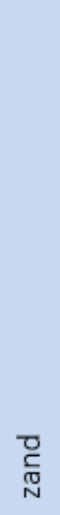 & $\begin{array}{l}\bar{D} \\
\overbrace{N}^{D}\end{array}$ & $\frac{\bar{\theta}}{\underline{y}}$ & 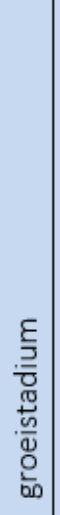 & 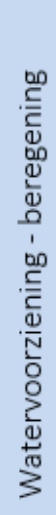 & 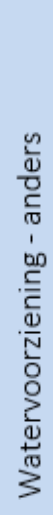 & 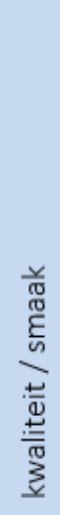 \\
\hline \multirow{4}{*}{14} & \multirow{4}{*}{$\begin{array}{c}\text { Kroot } \\
\text { (rode biet) }\end{array}$} & 1 & 2015 & 1070 & $x$ & & & & & & & & $x$ & & \\
\hline & & 2 & 2015 & 1200 & $x$ & & & & & & & & $x$ & & \\
\hline & & 3 & 2015 & 900 & $\times$ & & & & & & & & $x$ & & \\
\hline & & 4 & 2015 & 1200 & $x$ & & & & & & & & $x$ & & \\
\hline
\end{tabular}


C. Interpretatie
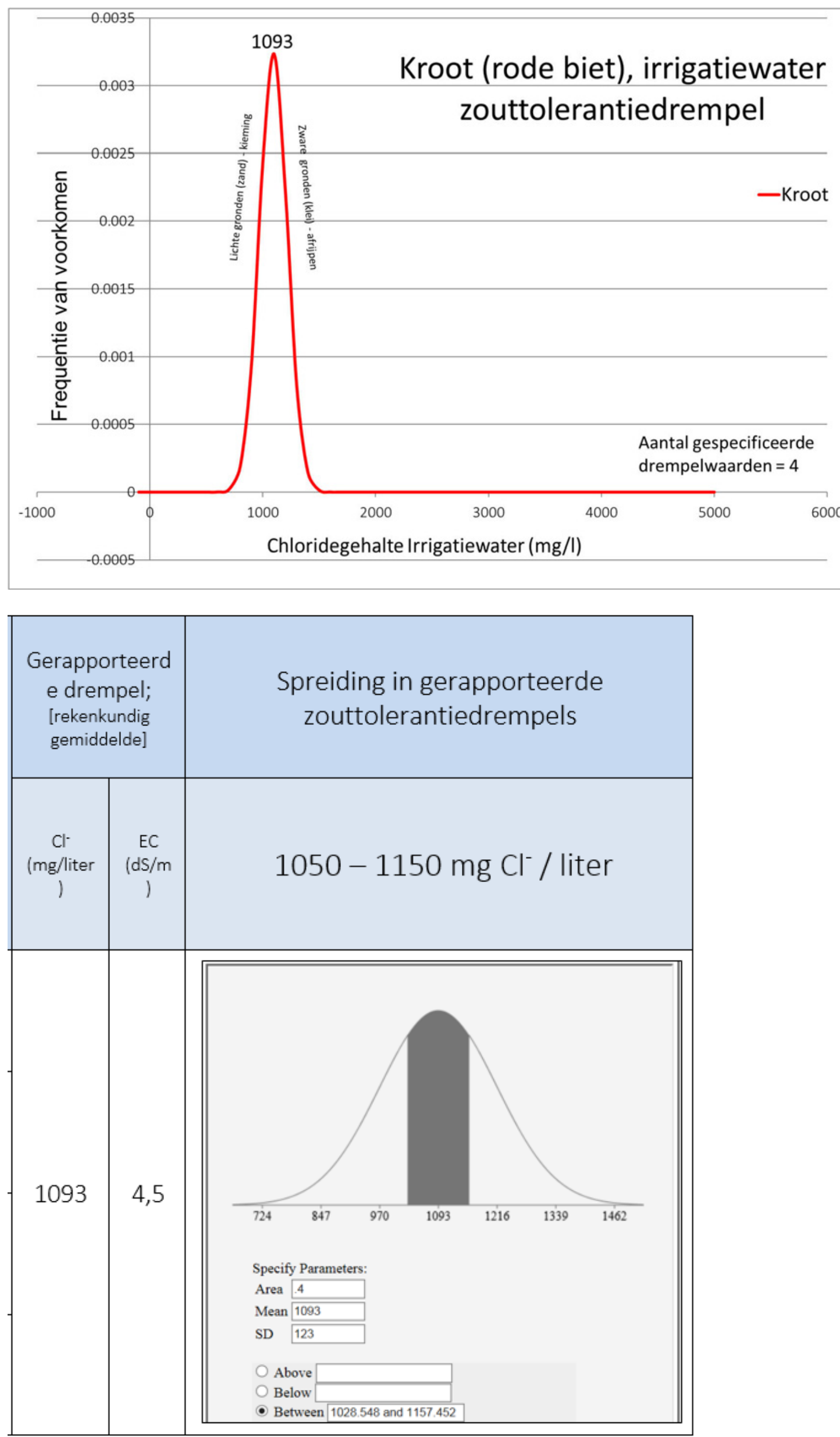


\subsection{Peen}

\section{A. Literatuur}

In Alterra rapport 2201 "Actualisering Zouttolerantie" (Bakel en Stuyt, 2011) is de tabel "Risico op zoutschade aan landbouwgewassen bij verschillende zoutgehalten van beregeningswater" beschikbaar gesteld door DLV Plant, die door hen voor advisering wordt gebruikt. Ook is in dit rapport een tabel met zouttolerantiewaarden opgenomen uit het PAGV-handboek (Proefstation voor de akkerbouw en de groetenteelt in de volle grond). Voor peen worden in deze tabellen de volgende waarden gehanteerd:
Bij lage tolerantie Bron DLV
$900 \mathrm{mg} \mathrm{CL/l}$
Bij hoge tolerantie Bron DLV
$1070 \mathrm{mg} \mathrm{CL} / \mathrm{l}$
Bij lage tolerantie Bron PAGV
$600 \mathrm{mg} \mathrm{CL} / \mathrm{l}$
Bij hoge tolerantie Bron PAGV
$900 \mathrm{mg} \mathrm{CL/l}$

\section{Referenties}

Eurofins (2015a) categoriseert peen als matig gevoelige vollegrondsgroente, met een zouttolerantiedrempel tussen 600 en $900 \mathrm{mg} \mathrm{Cl} / \mathrm{l}$.

Bakel, P.J.T. van en L.C.P.M. Stuyt, 2011. Actualisering van de kennis van de zouttolerantie van landbouwgewassen, op basis van literatuuronderzoek, expertkennis en praktische ervaringen. Wageningen, Alterra-rapport 2201.

Eurofins, 2015a. Waterkwaliteit in de akkerbouw. Bijlage/Toelichting. Eurofins Agro Laboratories, Wageningen. 


\section{B. Gegevens}

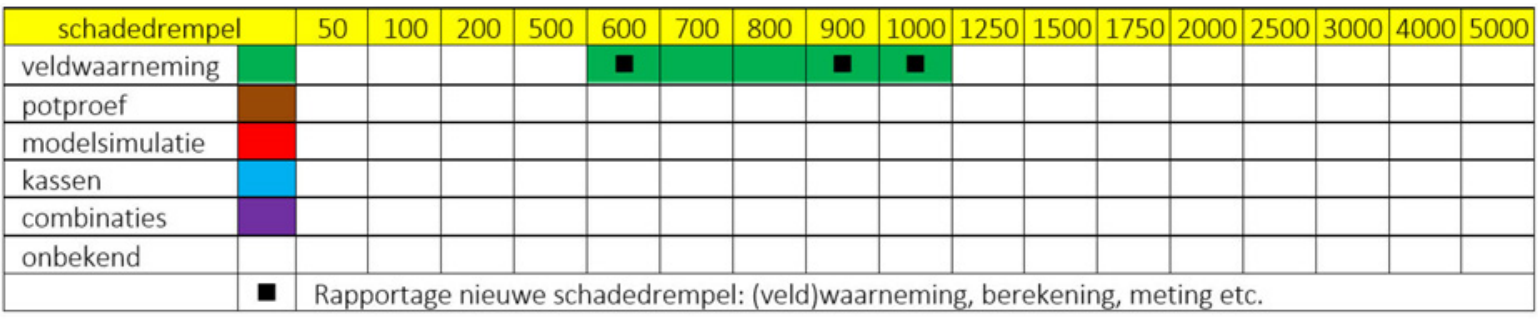

\begin{tabular}{|c|c|c|c|c|c|c|c|c|c|c|c|c|c|c|c|c|c|c|}
\hline jaar & & 1935 & 1940 & 1945 & 1950 & 1955 & 1960 & 1965 & 1970 & 1975 & 1980 & 1985 & 1990 & 1995 & 2000 & 2005 & 2010 & 2015 \\
\hline veldwaarneming & & & & & & & & & & & & & & & & & & 口 \\
\hline potproef & & & & & & & & & & & & & & & & & & \\
\hline modelsimulatie & & & & & & & & & & & & & & & & & & \\
\hline kassen & & & & & & & & & & & & & & & & & & \\
\hline combinaties & & & & & & & & & & & & & & & & & & \\
\hline onbekend & & & & & & & & & & & & & & & & & & \\
\hline
\end{tabular}

\begin{tabular}{|c|c|c|c|c|c|c|c|c|c|c|c|c|c|c|c|}
\hline No & Gewas(groep) & 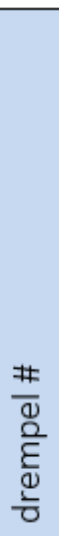 & $\begin{array}{l}\frac{1}{\pi} \\
\text {. } \\
\end{array}$ & 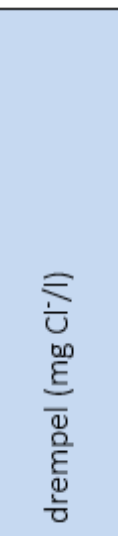 & 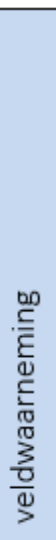 & 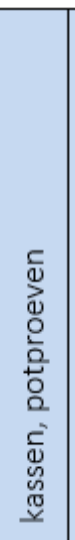 & 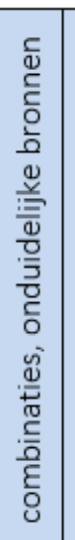 & 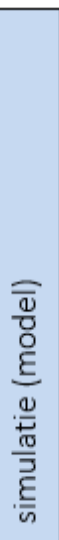 & $\begin{array}{l}\text { Dृ } \\
\text { ㅁ } \\
\text { N }\end{array}$ & 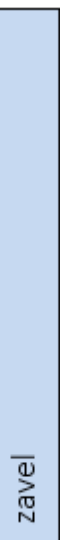 & $\frac{\bar{\alpha}}{\bar{x}}$ & 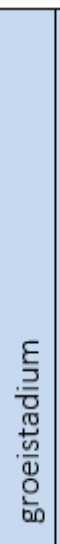 & 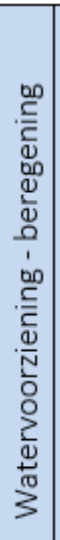 & 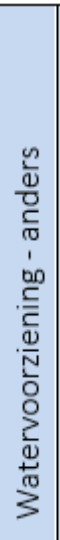 & 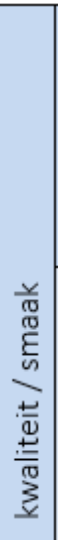 \\
\hline \multirow{4}{*}{15} & \multirow{4}{*}{ Peen } & 1 & 2015 & 900 & $x$ & & & & & & & & $x$ & & \\
\hline & & 2 & 2015 & 1070 & $x$ & & & & & & & & $x$ & & \\
\hline & & 3 & 2015 & 600 & $x$ & & & & & & & & $x$ & & \\
\hline & & 4 & 2015 & 900 & $x$ & & & & & & & & $x$ & & \\
\hline
\end{tabular}


C. Interpretatie
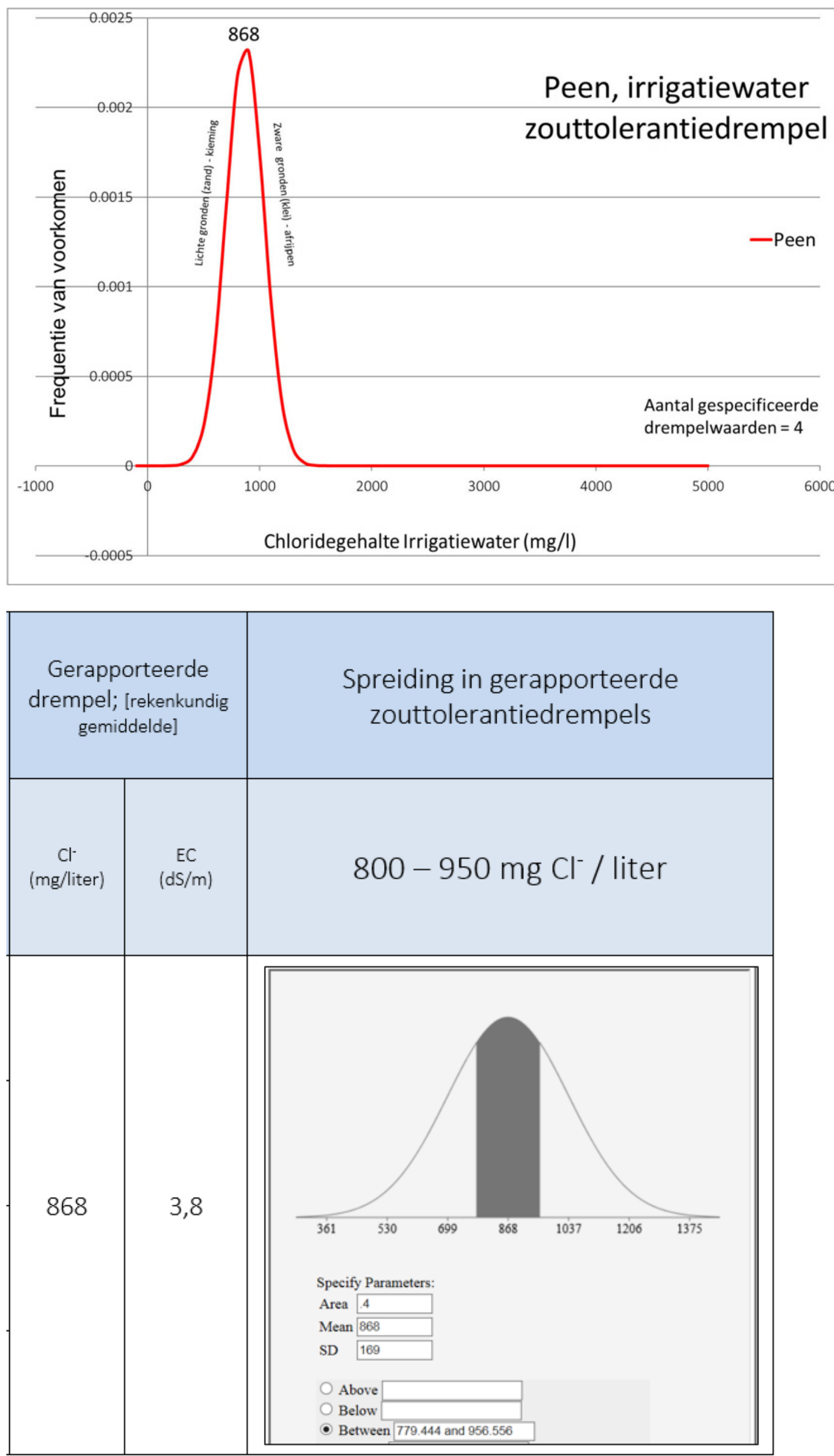


\subsection{Prei}

\section{A. Literatuur}

In Alterra rapport 2201 "Actualisering Zouttolerantie" (Bakel en Stuyt, 2011) is de tabel "Risico op zoutschade aan landbouwgewassen bij verschillende zoutgehalten van beregeningswater" beschikbaar gesteld door DLV Plant, die gebruikt wordt voor advisering. Ook is in dit rapport een tabel met zouttolerantiewaarden opgenomen uit het PAGV-handboek (Proefstation voor de akkerbouw en de groetenteelt in de volle grond). Voor prei worden in deze tabellen de volgende waarden gehanteerd:
Bij lage tolerantie:
Bron: DLV,
$900 \mathrm{mg} \mathrm{CL/l}$
Bij hoge tolerantie:
Bron: DLV, $1070 \mathrm{mg} \mathrm{CL/l}$
Bij lage tolerantie:
Bron: PAGV, $\quad 600 \mathrm{mg} \mathrm{CL/I}$
Bij hoge tolerantie:
Bron: PAGV
$900 \mathrm{mg} \mathrm{CL/l}$

Eurofins (2015a) categoriseert prei als matig gevoelige vollegrondsgroente, met een zouttolerantiedrempel tussen 600 en $900 \mathrm{mg} \mathrm{Cl} / \mathrm{l}$.

\section{Referenties}

Bakel, P.J.T. van en L.C.P.M. Stuyt, 2011. Actualisering van de kennis van de zouttolerantie van landbouwgewassen, op basis van literatuuronderzoek, expertkennis en praktische ervaringen. Wageningen, Alterra-rapport 2201.

Eurofins, 2015a. Waterkwaliteit in de akkerbouw. Bijlage/Toelichting. Eurofins Agro Laboratories, Wageningen. 


\section{B. Gegevens}

\begin{tabular}{|l|l|l|l|l|l|l|l|l|l|l|l|l|l|l|l|l|l|} 
schadedrempel & 50 & 100 & 200 & 500 & 600 & 700 & 800 & 900 & 1000 & 1250 & 1500 & 1750 & 2000 & 2500 & 3000 & 4000 & 5000 \\
\hline
\end{tabular} veldwaarneming

potproef

modelsimulatie

kassen

combinaties

onbekend

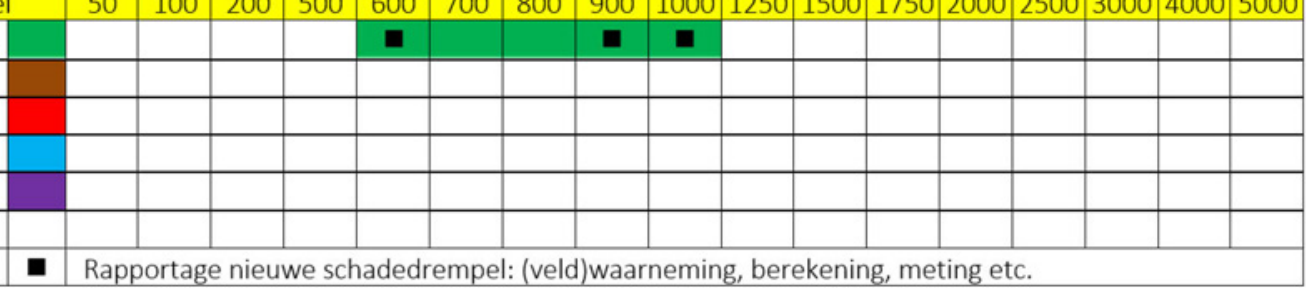

\begin{tabular}{|c|c|c|c|c|c|c|c|c|c|c|c|c|c|c|c|c|c|c|}
\hline jaar & & 1935 & 1940 & 1945 & 1950 & 1955 & 1960 & 1965 & 1970 & 1975 & 1980 & 1985 & 1990 & 1995 & 2000 & 2005 & 2010 & 2015 \\
\hline veldwaarneming & & & & & & & & & & & & & & & & & 口 & \\
\hline potproef & & & & & & & & & & & & & & & & & & \\
\hline modelsimulatie & & & & & & & & & & & & & & & & & & \\
\hline kassen & & & & & & & & & & & & & & & & & & \\
\hline combinaties & & & & & & & & & & & & & & & & & & \\
\hline onbekend & & & & & & & & & & & & & & & & & & \\
\hline & घ & Rapp & oortage & se nieı & Nes & Iade & rempel & I: (veld) & d)waarr & rnemin & ig, bere & eker & 3.1 & ting et & & & & \\
\hline
\end{tabular}

\begin{tabular}{|c|c|c|c|c|c|c|c|c|c|c|c|c|c|c|c|}
\hline No & Gewas(groep) & 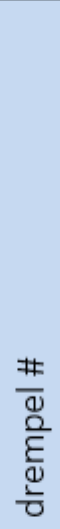 & $\begin{array}{l}\frac{1}{\pi} \\
.0 \\
.0\end{array}$ & 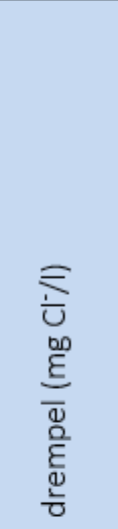 & 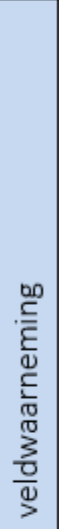 & 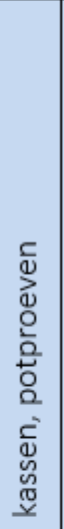 & 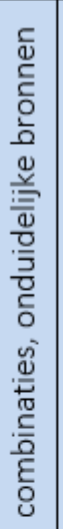 & 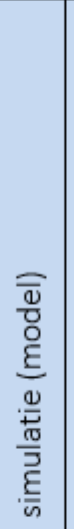 & $\underset{\substack{\text { T⿱ } \\
\text { T }}}{ }$ & 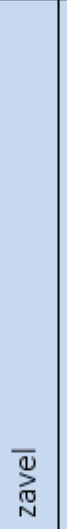 & $\frac{\bar{\omega}}{\underline{\underline{y}}}$ & 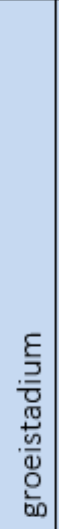 & 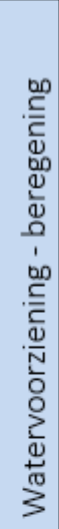 & 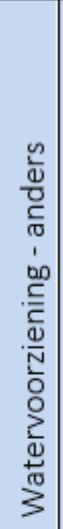 & 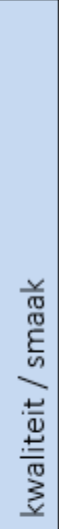 \\
\hline \multirow{5}{*}{16} & \multirow{5}{*}{ Prei } & 1 & 2011 & 1000 & $x$ & & & & & & & & $x$ & & \\
\hline & & 2 & 2015 & 900 & $x$ & & & & & & & & $x$ & & \\
\hline & & 3 & 2015 & 1070 & $\times$ & & & & & & & & $\times$ & & \\
\hline & & 4 & 2015 & 600 & $\times$ & & & & & & & & $\times$ & & \\
\hline & & 5 & 2015 & 900 & $x$ & & & & & & & & $\times$ & & \\
\hline
\end{tabular}


C. Interpretatie
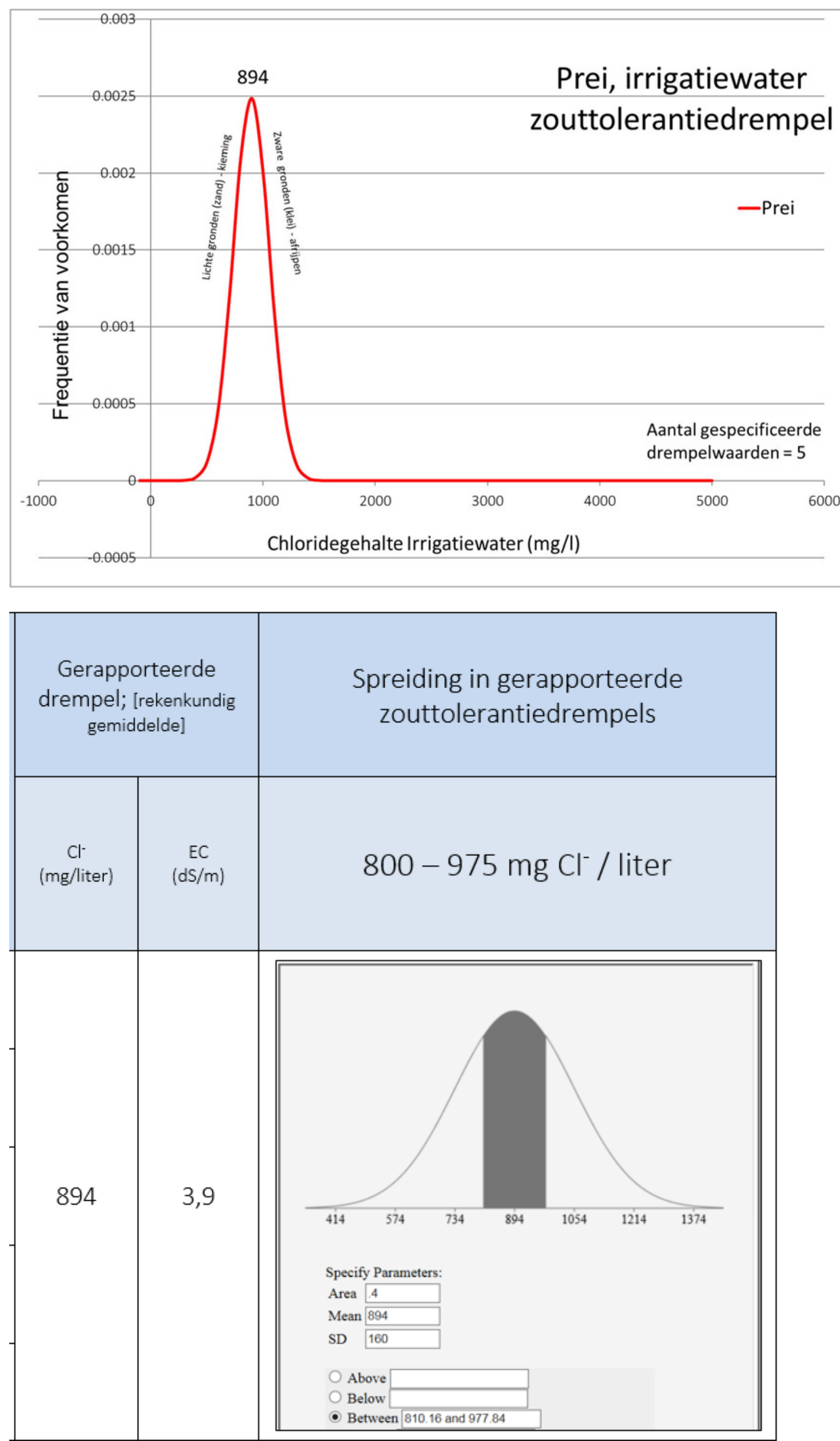


\subsection{Radijs}
A. Literatuur

$\begin{array}{lll}\text { Bij lage tolerantie: } & \text { Bron: DLV, } & 1070 \mathrm{mg} \mathrm{CL} / \mathrm{I} \\ \text { Bij hoge tolerantie: } & \text { Bron: DLV, } & 1200 \mathrm{mg} \mathrm{CL/l} \\ \text { Bij lage tolerantie: } & \text { Bron: PAGV, } & 900 \mathrm{mg} \mathrm{CL} / \mathrm{l} \\ \text { Bij hoge tolerantie: } & \text { Bron: PAGV, } & 1200 \mathrm{mg} \mathrm{CL/l}\end{array}$

In Alterra rapport 2201 "Actualisering Zouttolerantie" (Bakel en Stuyt, 2011) is de tabel "Risico op zoutschade aan landbouwgewassen bij verschillende zoutgehalten van beregeningswater" beschikbaar gesteld door DLV Plant, die gebruikt wordt voor advisering. Ook is in dit rapport een tabel met zouttolerantiewaarden opgenomen uit het PAGV-handboek (Proefstation voor de akkerbouw en de groetenteelt in de volle grond). Voor radijs worden in deze tabellen de volgende waarden gehanteerd:

Augurk wordt genoemd in een informatieblad met richtlijnen voor waterkwaliteit groententeelt vollegrond, uitgegeven door Eurofins (2015e). De bron(nen) van de in deze informatiebladen gespecificeerde grenswaarde(n) konden - ondanks gerichte navraag - niet worden achterhaald.

urofins (2015a) categoriseert radijs als weinig gevoelige vollegrondsgroente, met een zouttolerantiedrempel tussen 900 en $1200 \mathrm{mg} \mathrm{Cl} / \mathrm{l}$.

\section{Referenties}

Bakel, P.J.T. van en L.C.P.M. Stuyt, 2011. Actualisering van de kennis van de zouttolerantie van landbouwgewassen, op basis van literatuuronderzoek, expertkennis en praktische ervaringen. Wageningen, Alterra-rapport 2201.

Eurofins, 2015e. Waterkwaliteit in de groenteteelt vollegrond. Bijlage/Toelichting. Eurofins Agro Laboratories, Wageningen. 


\section{B. Gegevens}

\begin{tabular}{|l|l|l|l|l|l|l|l|l|l|l|l|l|l|l|l|l|l|} 
schadedrempel & 50 & 100 & 200 & 500 & 600 & 700 & 800 & 900 & 1000 & 1250 & 1500 & 1750 & 2000 & 2500 & 3000 & 4000 & 5000 \\
\hline
\end{tabular}

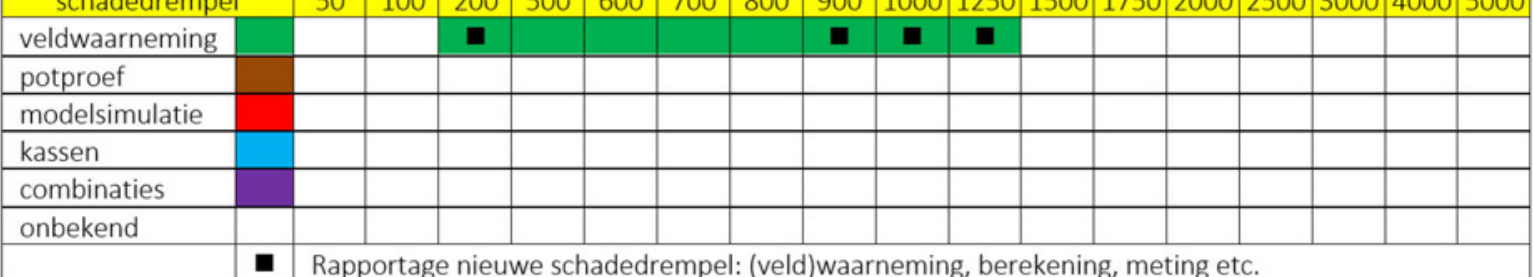

\begin{tabular}{|c|c|c|c|c|c|c|c|c|c|c|c|c|c|c|c|c|c|c|}
\hline jaar & & 1935 & 1940 & 1945 & \begin{tabular}{|l|}
1950 \\
\end{tabular} & 1955 & 1960 & 1965 & 1970 & 1975 & 1980 & 1985 & 1990 & 1995 & 2000 & 2005 & 2010 & 2015 \\
\hline veldwaarneming & & & & & & & & & & & & & & & 口 & & & 口 \\
\hline potproef & & & & & & & & & & & & & & & & & & \\
\hline modelsimulatie & & & & & & & & & & & & & & & & & & \\
\hline kassen & & & & & & & & & & & & & & & & & & \\
\hline combinaties & & & & & & & & & & & & & & & & & & \\
\hline onbekend & & & & & & & & & & & & & & & & & & \\
\hline & - & Rapp & 20rta & niou & & dradr & remnel & 1. (veld & d)warn & nemin & g, bere & rekenin & g, met & ting et & & & & \\
\hline
\end{tabular}

\begin{tabular}{|c|c|c|c|c|c|c|c|c|c|c|c|c|c|c|c|}
\hline No & Gewas(groep) & $\begin{array}{l}\text { \# } \\
\underline{0} \\
\text { है } \\
\frac{0}{0} \\
\frac{0}{0}\end{array}$ & 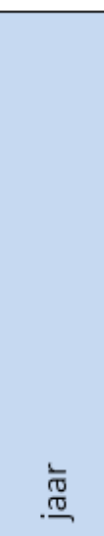 & 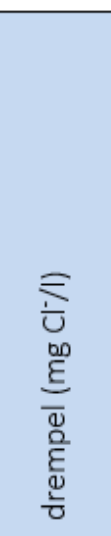 & 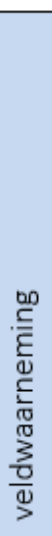 & 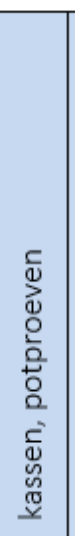 & 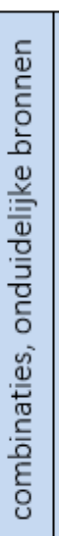 & 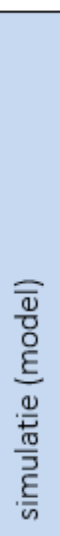 & 昰 & 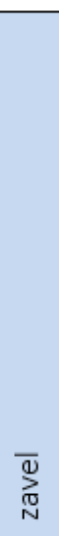 & $\frac{\bar{\omega}}{\underline{u}}$ & 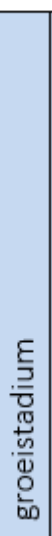 & 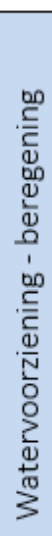 & 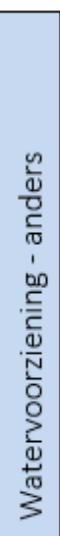 & 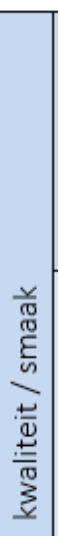 \\
\hline \multirow{5}{*}{17} & \multirow{5}{*}{ Radijs } & 1 & 1999 & 230 & $x$ & & & & & & & & $x$ & & \\
\hline & & 2 & 2015 & 1070 & $x$ & & & & & & & & $\times$ & & \\
\hline & & 3 & 2015 & 1200 & $x$ & & & & & & & & $x$ & & \\
\hline & & 4 & 2015 & 900 & $x$ & & & & & & & & $x$ & & \\
\hline & & 5 & 2015 & 1200 & $x$ & & & & & & & & $x$ & & \\
\hline
\end{tabular}


C. Interpretatie
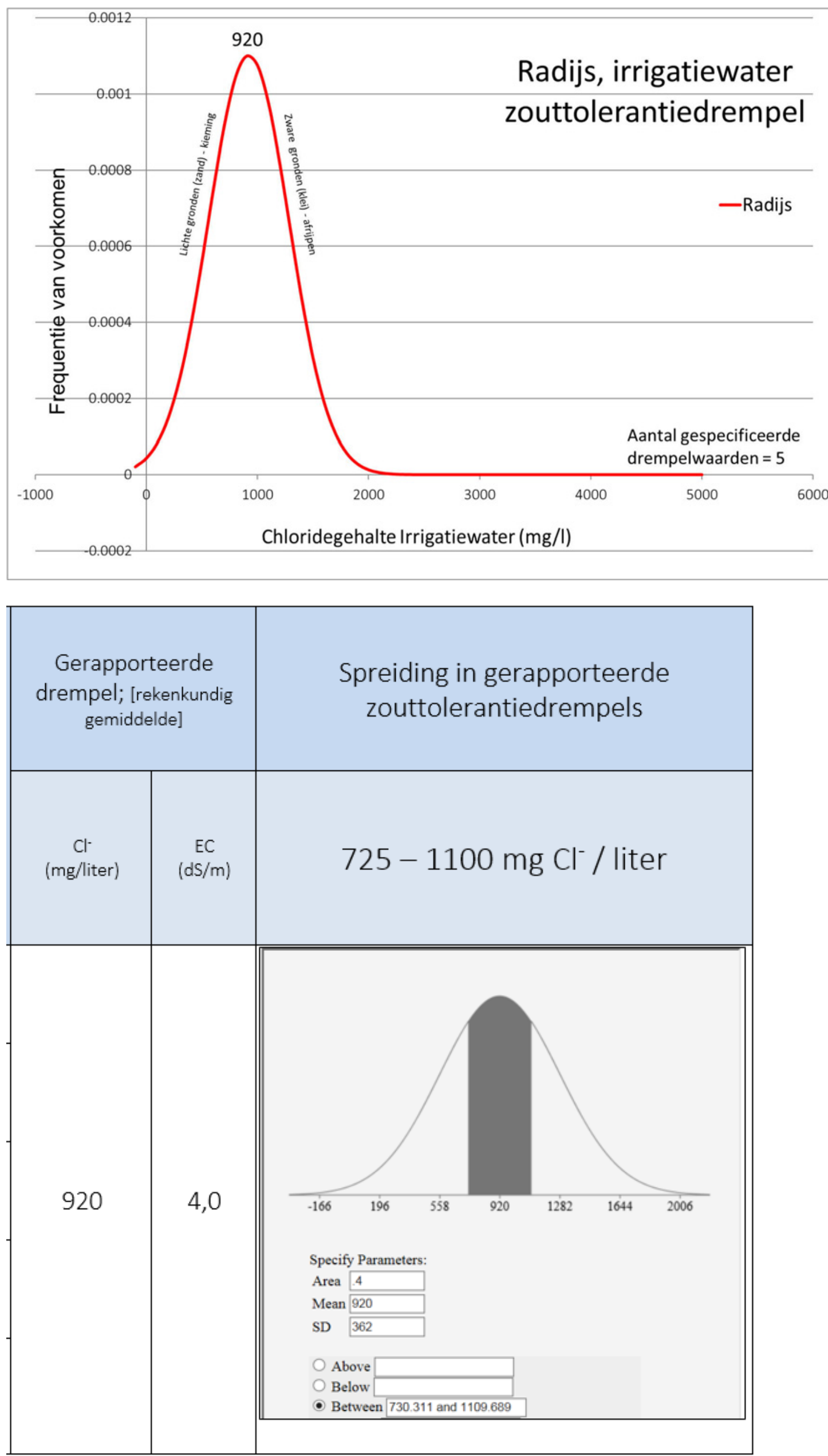


\subsection{Groene Savooiekool}
A. Literatuur gehanteerd:

$\begin{array}{llc}\text { Bij lage tolerantie: } & \text { Bron: DLV, } & 1070 \mathrm{mg} \mathrm{CL} / \mathrm{I} \\ \text { Bij hoge tolerantie: } & \text { Bron: DLV, } & 1200 \mathrm{mg} \mathrm{CL/l} \\ \text { Bij lage tolerantie: } & \text { Bron: PAGV, } & 900 \mathrm{mg} \mathrm{CL} / \mathrm{l} \\ \text { Bij hoge tolerantie: } & \text { Bron: PAGV, } & 1200 \mathrm{mg} \mathrm{CL/l}\end{array}$

In Alterra rapport 2201 "Actualisering Zouttolerantie" (Bakel en Stuyt, 2011) is de tabel "Risico op zoutschade aan landbouwgewassen bij verschillende zoutgehalten van beregeningswater" beschikbaar gesteld door DLV Plant, die gebruikt wordt voor advisering. Ook is in dit rapport een tabel met zouttolerantiewaarden opgenomen uit het PAGV-handboek (Proefstation voor de akkerbouw en de groetenteelt in de volle grond). Voor groene savooiekool worden in deze tabellen de volgende waarden

Eurofins (2015a) categoriseert groene savooiekool als weinig gevoelige vollegrondsgroente met een zouttolerantiedrempel van 900-1200 mg.

\section{Referenties}

Bakel P.J.T., R.A.L. Kselik, C.W.J. Roest en A.A.M.F.R. Smit. 2009. Review of crop salt tolerance in the Netherlands. Rapport 1926, Alterra, Wageningen.

Bakel, P.J.T. van en L.C.P.M. Stuyt, 2011. Actualisering van de kennis van de zouttolerantie van landbouwgewassen, op basis van literatuuronderzoek, expertkennis en praktische ervaringen. Wageningen, Alterra-rapport 2201.

Eurofins, 2015a. Waterkwaliteit in de akkerbouw. Bijlage/Toelichting. Eurofins Agro Laboratories, Wageningen. 


\section{B. Gegevens}

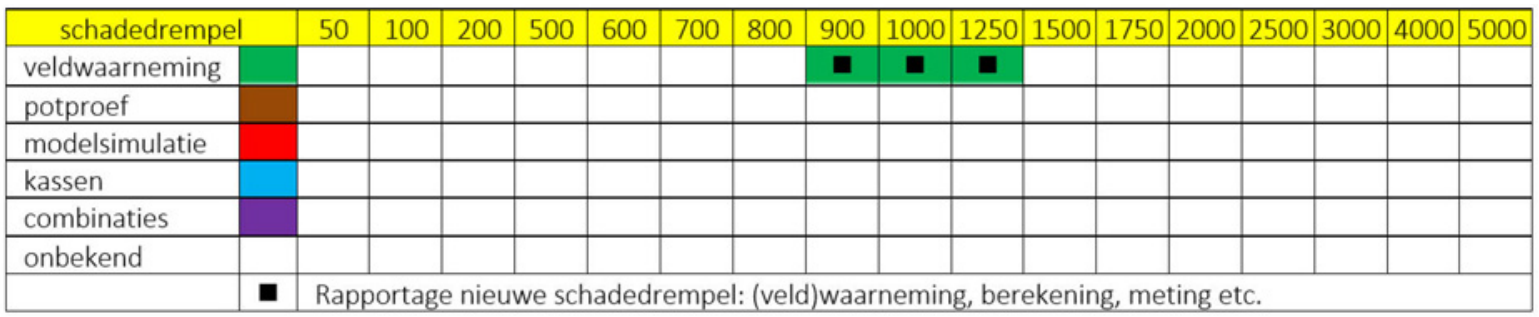

\begin{tabular}{|c|c|c|c|c|c|c|c|c|c|c|c|c|c|c|c|c|c|c|}
\hline jaar & & 1935 & 1940 & 1945 & 1950 & 1955 & 1960 & 1965 & 1970 & 1975 & 1980 & 1985 & 1990 & 1995 & 2000 & 2005 & 2010 & 2015 \\
\hline veldwaarneming & & & & & & & & & & & & & & & & & & 口 \\
\hline potproef & & & & & & & & & & & & & & & & & & \\
\hline kassen & & & & & & & & & & & & & & & & & & \\
\hline combinaties & & & & & & & & & & & & & & & & & & \\
\hline onbekend & & & & & & & & & & & & & & & & & & \\
\hline
\end{tabular}

\begin{tabular}{|c|c|c|c|c|c|c|c|c|c|c|c|c|c|c|c|}
\hline No & Gewas(groep) & 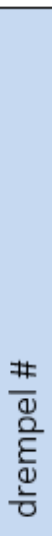 & 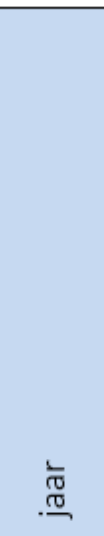 & 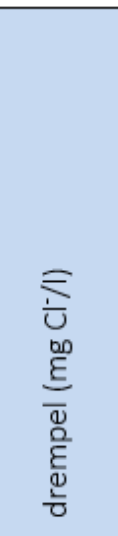 & 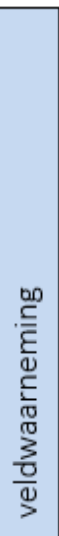 & 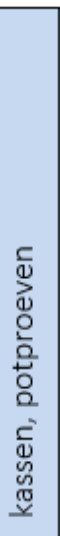 & 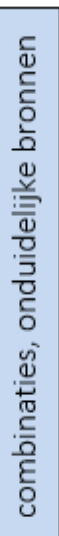 & 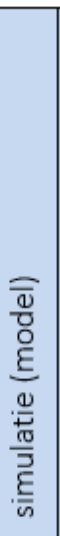 & $\begin{array}{l}\text { D } \\
\underset{N}{\mathbb{N}} \\
\text { N }\end{array}$ & 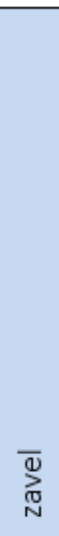 & $\frac{\bar{\omega}}{\underline{y}}$ & 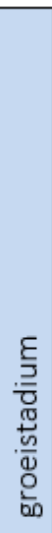 & 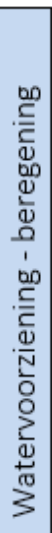 & 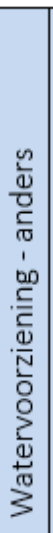 & 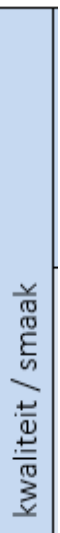 \\
\hline \multirow{4}{*}{18} & \multirow{4}{*}{$\begin{array}{c}\text { Groene } \\
\text { Savooiekool }\end{array}$} & 1 & 2015 & 1070 & $x$ & & & & & & & & $x$ & & \\
\hline & & 2 & 2015 & 1200 & $x$ & & & & & & & & $\times$ & & \\
\hline & & 3 & 2015 & 900 & $\times$ & & & & & & & & $x$ & & \\
\hline & & 4 & 2015 & 1200 & $x$ & & & & & & & & $x$ & & \\
\hline
\end{tabular}


C. Interpretatie
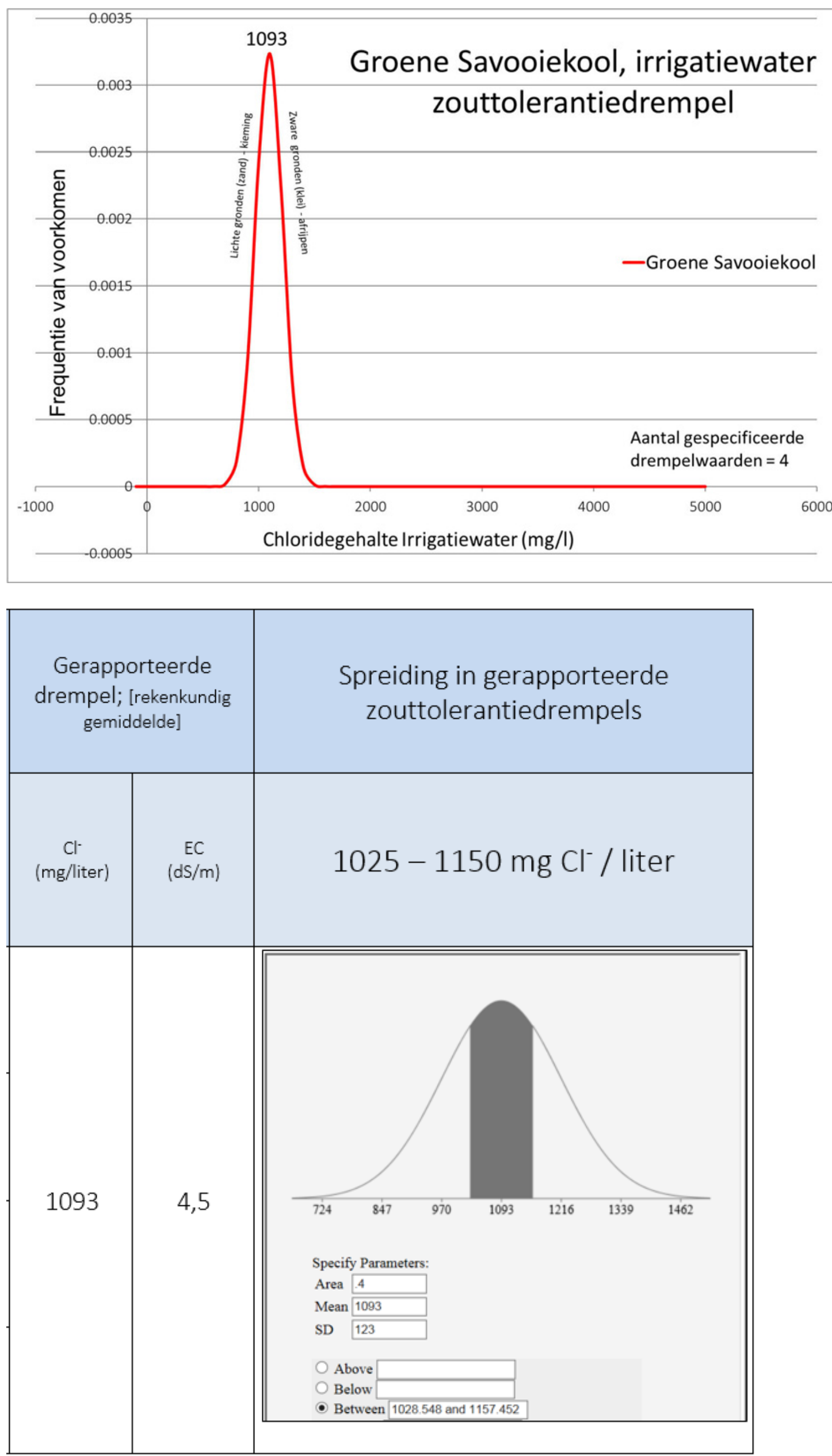


\subsection{Spinazie}

\section{A. Literatuur}

Door Shannon \& Grieve (1999) is een grafiek met drempelwaarden voor zouttoleranties van diverse gewassen gepubliceerd. Voor spinazie wordt hierin een waarde vermeld van circa 2,0 dS/m, wat overeenkomt met $375 \mathrm{mg} / \mathrm{l} \mathrm{Cl}$.

In Alterra rapport 2201 "Actualisering Zouttolerantie" (Bakel en Stuyt, 2011) is de tabel "Risico op zoutschade aan landbouwgewassen bij verschillende zoutgehalten van beregeningswater" beschikbaar gesteld door DLV Plant, die gebruikt wordt voor advisering. Ook is in dit rapport een tabel met zouttolerantiewaarden opgenomen uit het PAGV-handboek (Proefstation voor de akkerbouw en de groetenteelt in de volle grond). Voor spinazie worden in deze tabellen de volgende waarden gehanteerd:

Bij hoge tolerantie: Bron: DLV, $1200 \mathrm{mg} \mathrm{CL/l}$

Bij lage tolerantie: Bron: PAGV, $900 \mathrm{mg} \mathrm{CL/l}$

Bij hoge tolerantie: Bron: PAGV, $1200 \mathrm{mg} \mathrm{CL} / \mathrm{l}$

Eurofins (2015a) categoriseert spinazie als weinig gevoelige vollegrondsgroente met een zouttolerantiedrempel van $900-1200 \mathrm{mg}$.

\section{Referenties}

Bakel, P.J.T. van en L.C.P.M. Stuyt, 2011. Actualisering van de kennis van de zouttolerantie van landbouwgewassen, op basis van literatuuronderzoek, expertkennis en praktische ervaringen. Wageningen, Alterra-rapport 2201.

Eurofins, 2015a. Waterkwaliteit in de akkerbouw. Bijlage/Toelichting. Eurofins Agro Laboratories, Wageningen.

Shannon, M.C. \& C.M. Grieve, 1999. Tolerance of vegetable crops to salinity. Scientia Horticulturae 78: $5-38$ 


\section{B. Gegevens}

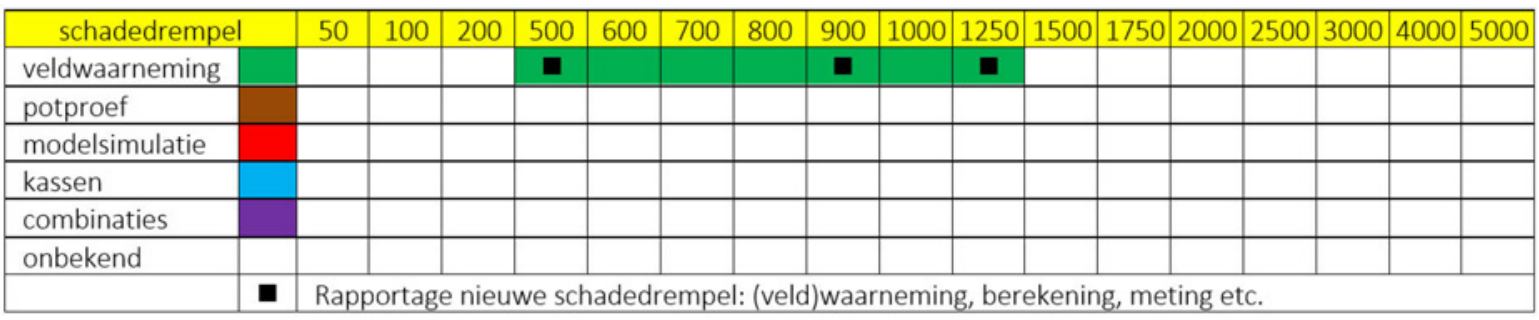

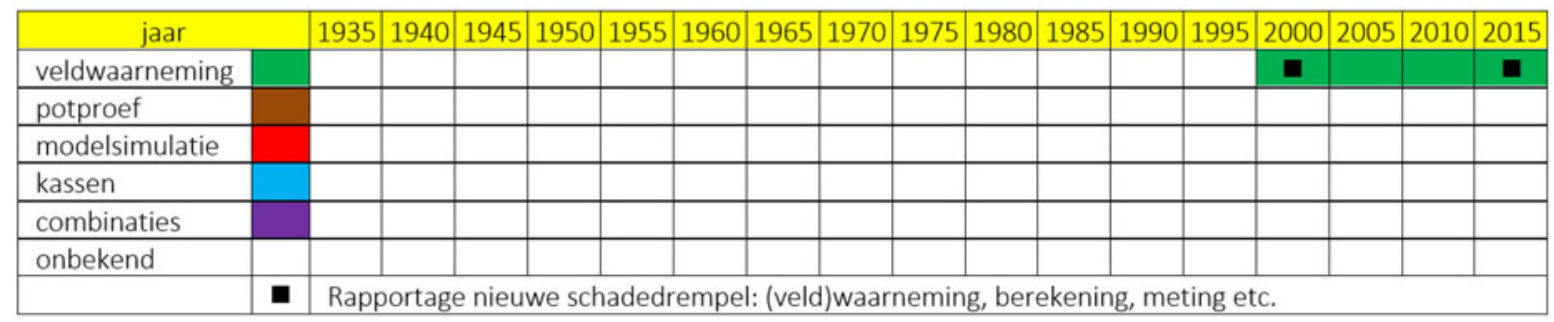

\begin{tabular}{|c|c|c|c|c|c|c|c|c|c|c|c|c|c|c|c|}
\hline No & Gewas(groep) & 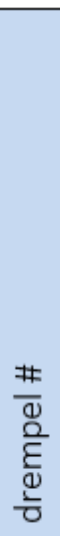 & 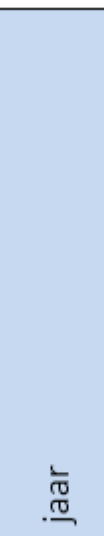 & 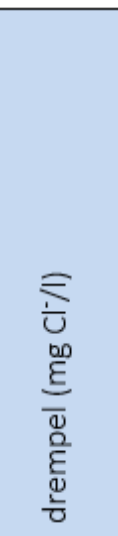 & 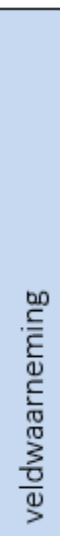 & 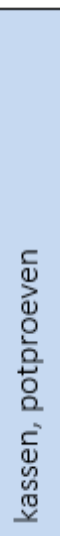 & 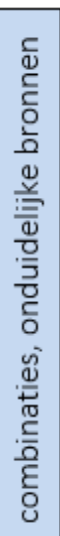 & 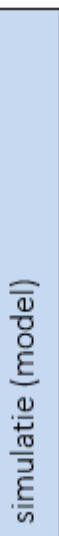 & 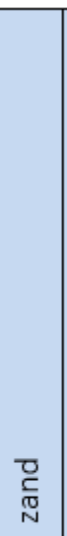 & 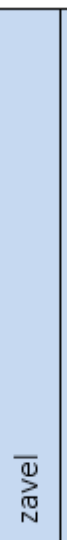 & $\frac{\bar{\omega}}{\underline{y}}$ & 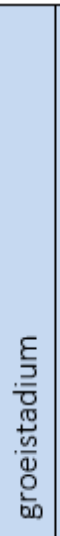 & 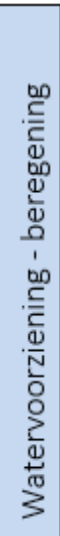 & 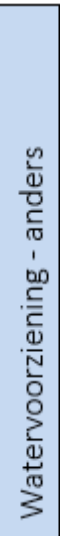 & 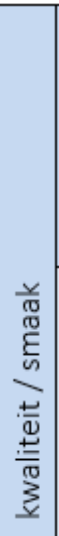 \\
\hline \multirow{4}{*}{19} & \multirow{4}{*}{ Spinazie } & 1 & 1999 & 375 & $\times$ & & & & & & & & $x$ & & \\
\hline & & 2 & 2015 & 1200 & $x$ & & & & & & & & $\times$ & & \\
\hline & & 3 & 2015 & 900 & $x$ & & & & & & & & $x$ & & \\
\hline & & 4 & 2015 & 1200 & $x$ & & & & & & & & $\times$ & & \\
\hline
\end{tabular}


C. Interpretatie
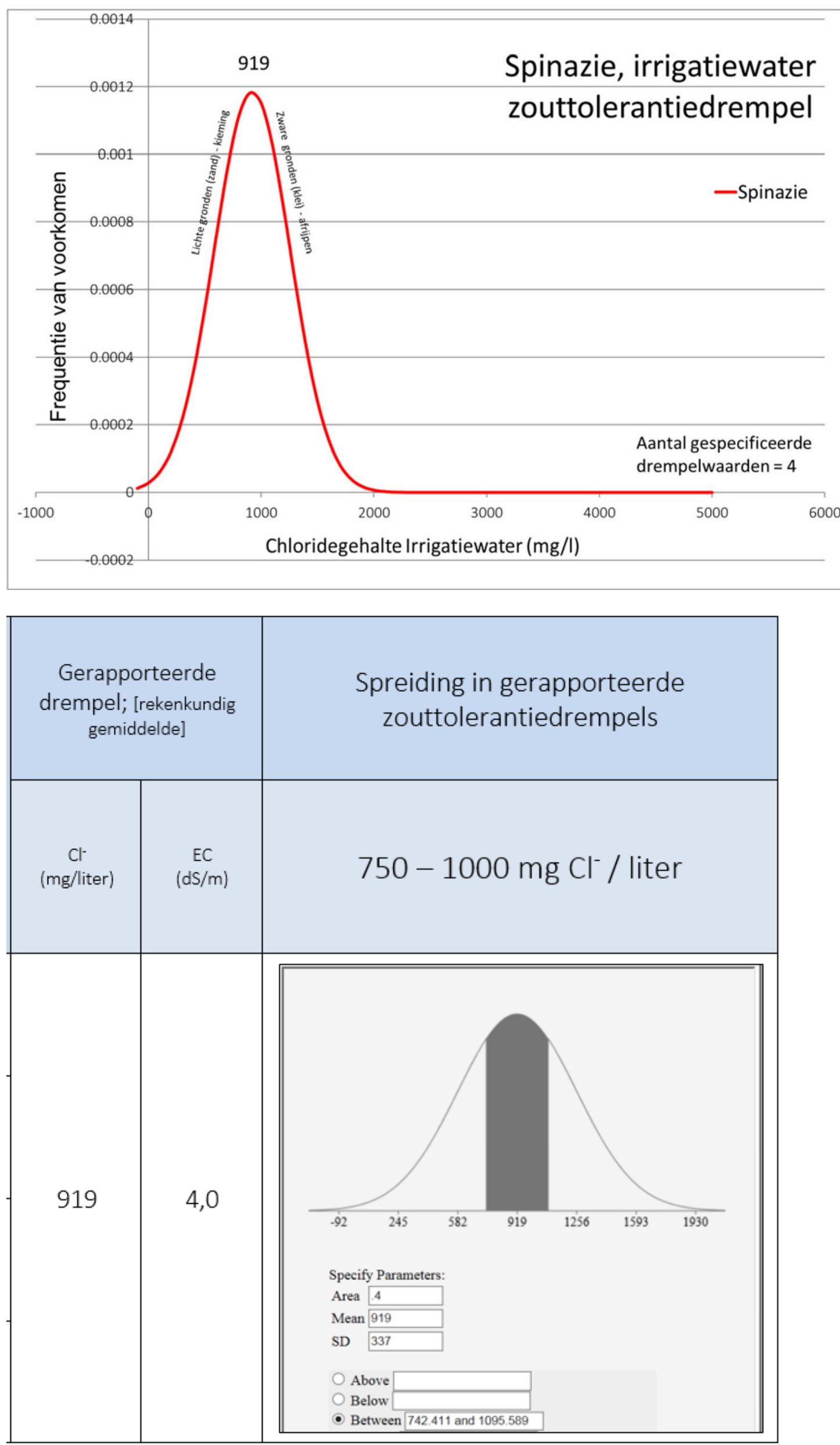


\subsection{Suikerbieten}

\section{A. Literatuur}

In 1983 wordt in ICW nota 1461 (P.C. Jansen) $600 \mathrm{mg} / \mathrm{l}$ vermeld voor het toelaatbare chloridegehalte van beregeningswater.

Uit het literatuuronderzoek "Actualisering Zouttolerantie" door Roest et al. (2003), dat werd uitgevoerd ten behoeve van de ontwikkeling en het gebruik van het RIZA-instrumentarium, is een waarde voor het $10 \%$ gevoeligste gewas afgeleid, d.w.z. $1250 \mathrm{mg} / \mathrm{l} \mathrm{Cl}$ voor de categorie suikerbieten.

In 2009 werd de studie "Review of crop salt tolerance in the Netherlands" uitgevoerd. In dit project zijn met behulp van het computermodel SWAP (Wageningen UR-Alterra) de volgende drempelwaarden voor $0 \%$ gewasschade bij suikerbieten op drie verschillende bodems in het droogste jaar 1976 vastgesteld: $1850 \mathrm{mg} / \mathrm{l} \mathrm{Cl}$ voor zandgrond, > $5000 \mathrm{mg} / \mathrm{l}$ voor zavelgrond en $3450 \mathrm{mg} / \mathrm{l}$ voor kleigrond (Alterra-rapport 1926).

In Alterra rapport 2201 "Actualisering Zouttolerantie" (Bakel en Stuyt, 2011) is een tabel met zouttolerantiewaarden uit het PAGV-handboek opgenomen (Proefstation voor de akkerbouw en de groetenteelt in de volle grond). Voor suikerbieten worden in deze tabel de volgende waarden gehanteerd:

Bij lage tolerantie: Bron: PAGV, $900 \mathrm{mg} \mathrm{CL/l}$

Bij hoge tolerantie: Bron: PAGV, $1200 \mathrm{mg} \mathrm{CL/l}$

Eurofins (2015a) categoriseert 'bieten' als weinig gevoelige akkerbouwgewassen met een zouttolerantiedrempel van 900-1200 mg.

\section{Referenties}

Bakel P.J.T., R.A.L. Kselik, C.W.J. Roest en A.A.M.F.R. Smit. 2009. Review of crop salt tolerance in the Netherlands. Rapport 1926, Alterra, Wageningen.

Bakel, P.J.T. van en L.C.P.M. Stuyt, 2011. Actualisering van de kennis van de zouttolerantie van landbouwgewassen, op basis van literatuuronderzoek, expertkennis en praktische ervaringen. Wageningen, Alterra-rapport 2201.

Eurofins, 2015a. Waterkwaliteit in de akkerbouw. Bijlage/Toelichting. Eurofins Agro Laboratories, Wageningen.

Jansen, P.C., 1983. Waterkwaliteit. Een beknopt overzicht van begrippen, parameters, typering en normen. Instituut voor Cultuurtechniek en Waterhuishouding, ICW-Nota 1461, Wageningen. pp. 26-28.

Roest, C.W.J., P.J.T. van Bakel \&, A.A.M.F.R. Smit, 2003. Actualisering van de zouttolerantie van landen tuinbouwgewassen ten behoeve van de berekening van de zoutschade in Nederland met het RIZA-instrumentarium. Memo Alterra, Wageningen, $16 \mathrm{p}$. 


\section{B. Gegevens}
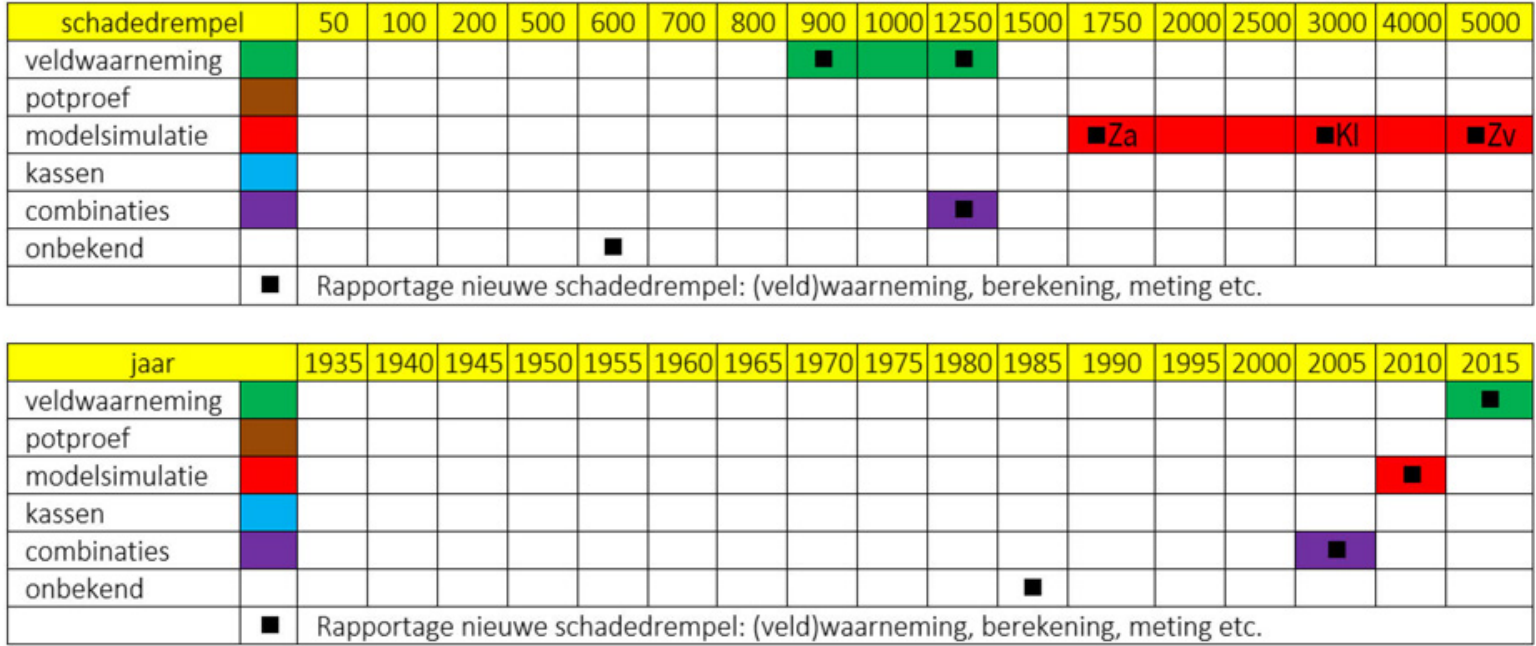

\begin{tabular}{|c|c|c|c|c|c|c|c|c|c|c|c|c|c|c|c|}
\hline No & Gewas(groep) & 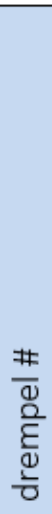 & 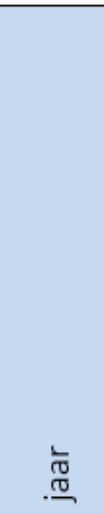 & 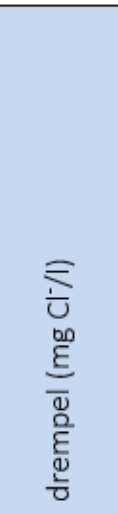 & 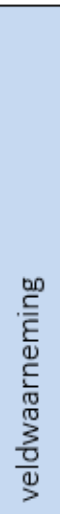 & 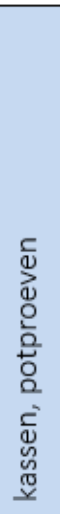 & 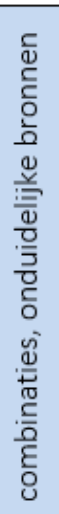 & 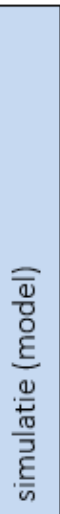 & 胥 & $\begin{array}{l}\bar{D} \\
\stackrel{N}{N}\end{array}$ & $\frac{\bar{\omega}}{\underline{y}}$ & 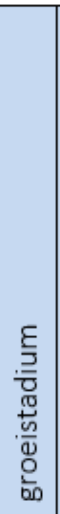 & 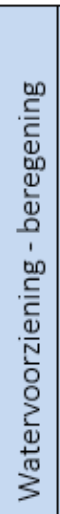 & 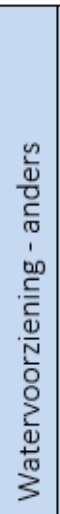 & 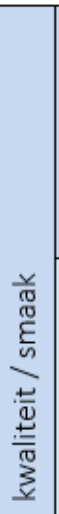 \\
\hline \multirow{9}{*}{20} & \multirow{9}{*}{ Suikerbieten } & 1 & 1983 & 600 & $x$ & & & & & & & & & & \\
\hline & & 2 & 2003 & 1288 & & & $x$ & & & & & & $x$ & & \\
\hline & & 3 & 2003 & 1288 & & & $x$ & & & & & & $x$ & & \\
\hline & & 4 & 2003 & 1250 & & & $x$ & & & & & & $x$ & & \\
\hline & & 5 & 2009 & 1850 & & & & $x$ & $x$ & & & & & & \\
\hline & & 6 & 2009 & 3450 & & & & $x$ & & & $x$ & & & & \\
\hline & & 7 & 2009 & 5000 & & & & $x$ & & $x$ & & & & & \\
\hline & & 8 & 2015 & 900 & $x$ & & & & & & & & & & \\
\hline & & 9 & 2015 & 1200 & $x$ & & & & & & & & & & \\
\hline
\end{tabular}


C. Interpretatie

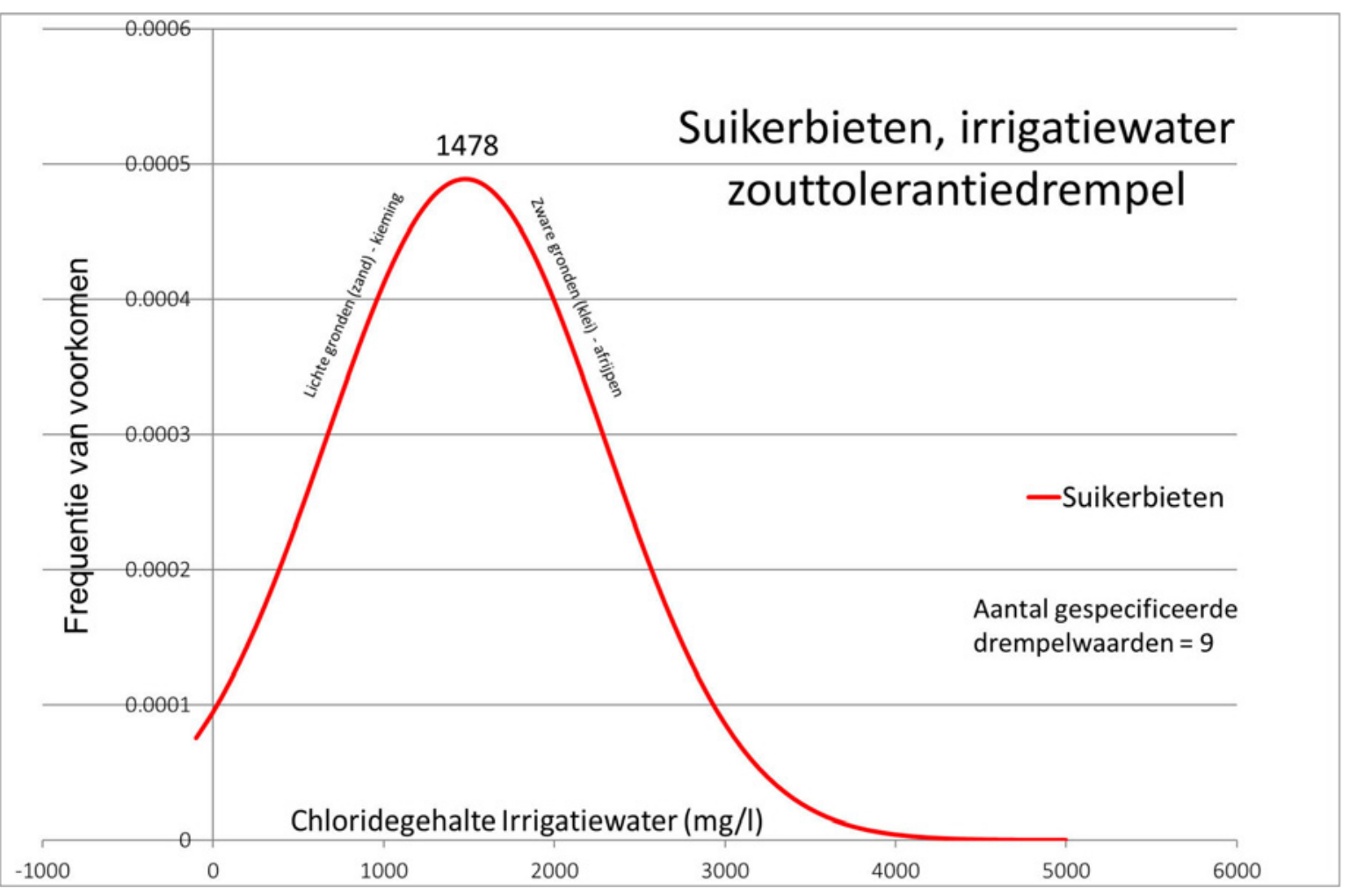

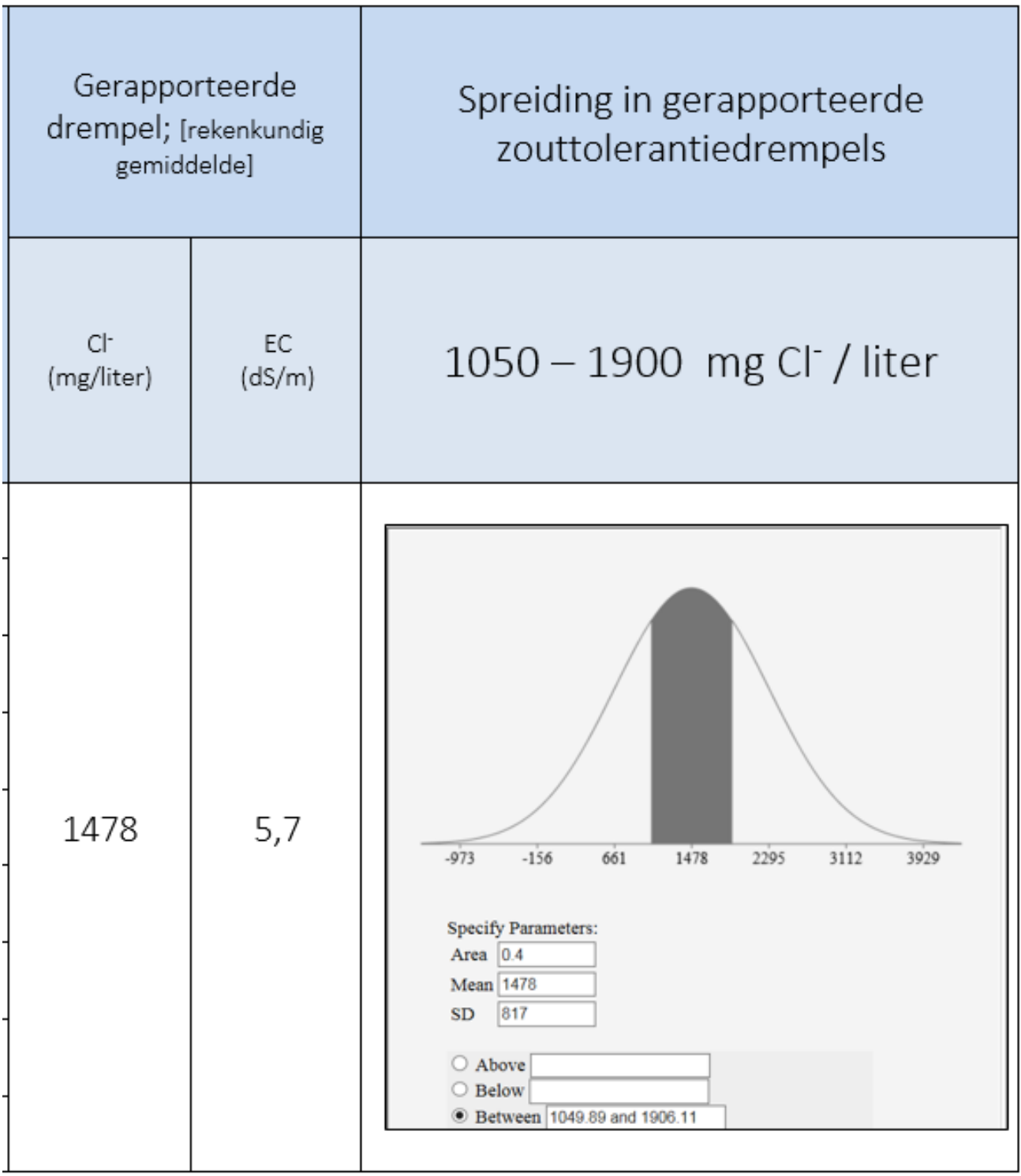




\subsection{Uien}

\section{A. Literatuur}

Door Shannon \& Grieve (1999) is een grafiek met drempelwaarden voor zouttoleranties van diverse gewassen gepubliceerd. Voor uien is hieruit een drempelwaarde ontleend van circa $1,4 \mathrm{dS} / \mathrm{m}$, wat overeenkomt met $230 \mathrm{mg} / \mathrm{l} \mathrm{Cl}$.

In Alterra rapport 2201 "Actualisering Zouttolerantie" (Bakel en Stuyt, 2011) is de tabel "Risico op zoutschade aan landbouwgewassen bij verschillende zoutgehalten van beregeningswater" beschikbaar gesteld door DLV Plant, die gebruikt wordt voor advisering. Ook is in dit rapport een tabel met zouttolerantiewaarden opgenomen uit het PAGV-handboek (Proefstation voor de akkerbouw en de groetenteelt in de volle grond). Voor uien worden in deze tabellen de volgende waarden gehanteerd:

$\begin{array}{lll}\text { Bij lage tolerantie: } & \text { Bron: DLV, } & 1070 \mathrm{mg} \mathrm{CL} / \mathrm{l} \\ \text { Bij hoge tolerantie: } & \text { Bron: DLV, } & 1200 \mathrm{mg} \mathrm{CL} / \mathrm{l} \\ \text { Bij lage tolerantie: } & \text { Bron: PAGV, } & 600 \mathrm{mg} \mathrm{CL/l} \\ \text { Bij hoge tolerantie: } & \text { Bron: PAGV, } & 900 \mathrm{mg} \mathrm{CL/l}\end{array}$

Eurofins (2015a) categoriseert uien als matig gevoelige akkerbouwgewassen met een zouttolerantiedrempel van $600-900 \mathrm{mg} \mathrm{Cl} / \mathrm{l}$.

\section{Referenties}

Bakel, P.J.T. van en L.C.P.M. Stuyt, 2011. Actualisering van de kennis van de zouttolerantie van landbouwgewassen, op basis van literatuuronderzoek, expertkennis en praktische ervaringen. Wageningen, Alterra-rapport 2201.

Eurofins, 2015a. Waterkwaliteit in de akkerbouw. Bijlage/Toelichting. Eurofins Agro Laboratories, Wageningen.

Shannon, M.C. \& C.M. Grieve, 1999. Tolerance of vegetable crops to salinity. Scientia Horticulturae 78: 5-38. 


\section{B. Gegevens}

\begin{tabular}{|l|l|l|l|l|l|l|l|l|l|l|l|l|l|l|l|l|l|}
\hline schadedrempel & 50 & 100 & 200 & 500 & 600 & 700 & 800 & 900 & 1000 & 1250 & 1500 & 1750 & 2000 & 2500 & 3000 & 4000 & 5000 \\
\hline
\end{tabular}

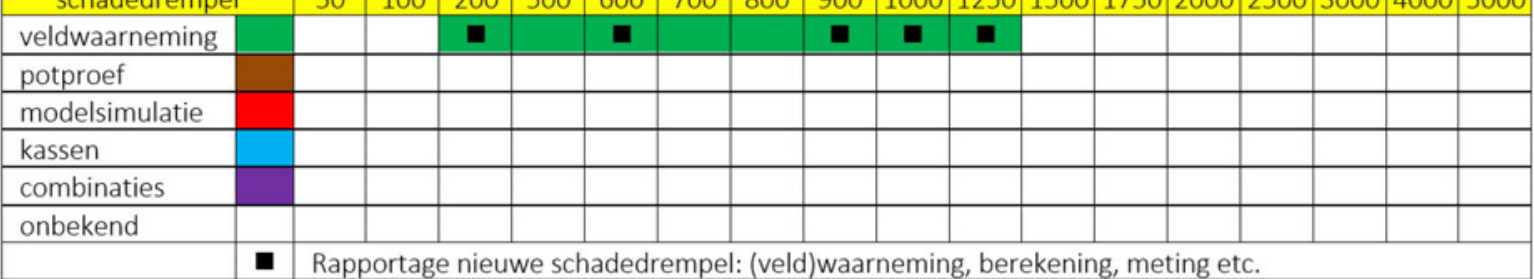

\begin{tabular}{|c|c|c|c|c|c|c|c|c|c|c|c|c|c|c|c|c|c|c|}
\hline jaar & & 1935 & 1940 & 1945 & 1950 & 1955 & 1960 & 1965 & 1970 & 1975 & 1980 & 1985 & 1990 & 1995 & 2000 & 2005 & 2010 & 2015 \\
\hline veldwaarneming & & & & & & & & & & & & & & & 口 & & 口 & a \\
\hline potproef & & & & & & & & & & & & & & & & & & \\
\hline modelsimulatie & & & & & & & & & & & & & & & & & & \\
\hline kassen & & & & & & & & & & & & & & & & & & \\
\hline combinaties & & & & & & & & & & & & & & & & & & \\
\hline onbekend & & & & & & & & & & & & & & & & & & \\
\hline & - & Rapp & & e nieur & & adedre & & : (veld & d)warr & nemin & g, bere & ekenin & $\mathrm{g}$, met & ting etc & & & & \\
\hline
\end{tabular}

\begin{tabular}{|c|c|c|c|c|c|c|c|c|c|c|c|c|c|c|c|}
\hline No & Gewas(groep) & 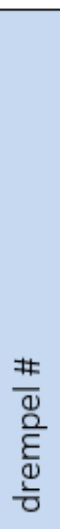 & 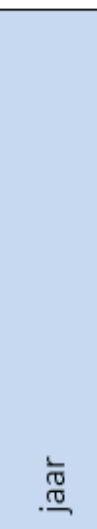 & 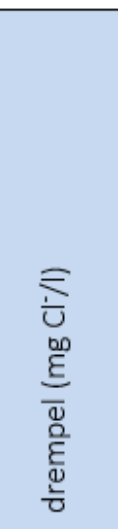 & 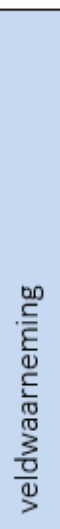 & 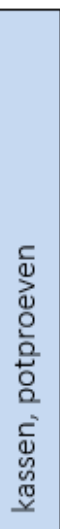 & 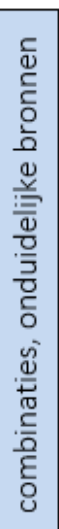 & 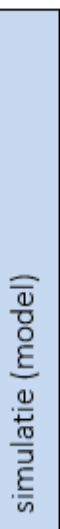 & $\begin{array}{l}\text { T } \\
\underset{N}{N}\end{array}$ & 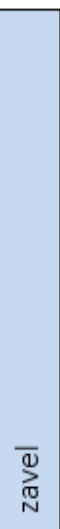 & $\frac{\bar{\omega}}{\underline{y}}$ & 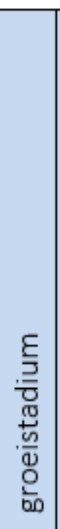 & 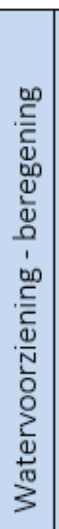 & 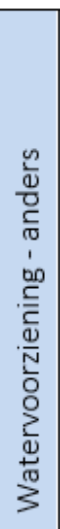 & 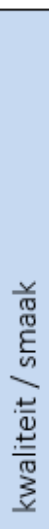 \\
\hline \multirow{6}{*}{21} & \multirow{6}{*}{ Uien } & 1 & 1999 & 230 & $x$ & & & & & & & & & & \\
\hline & & 2 & 2011 & 1200 & $\times$ & & & & & & & & $x$ & & \\
\hline & & 3 & 2015 & 1070 & $x$ & & & & & & & & $x$ & & \\
\hline & & 4 & 2015 & 1200 & $x$ & & & & & & & & $x$ & & \\
\hline & & 5 & 2015 & 600 & $x$ & & & & & & & & $x$ & & \\
\hline & & 6 & 2015 & 900 & $x$ & & & & & & & & $x$ & & \\
\hline
\end{tabular}


C. Interpretatie

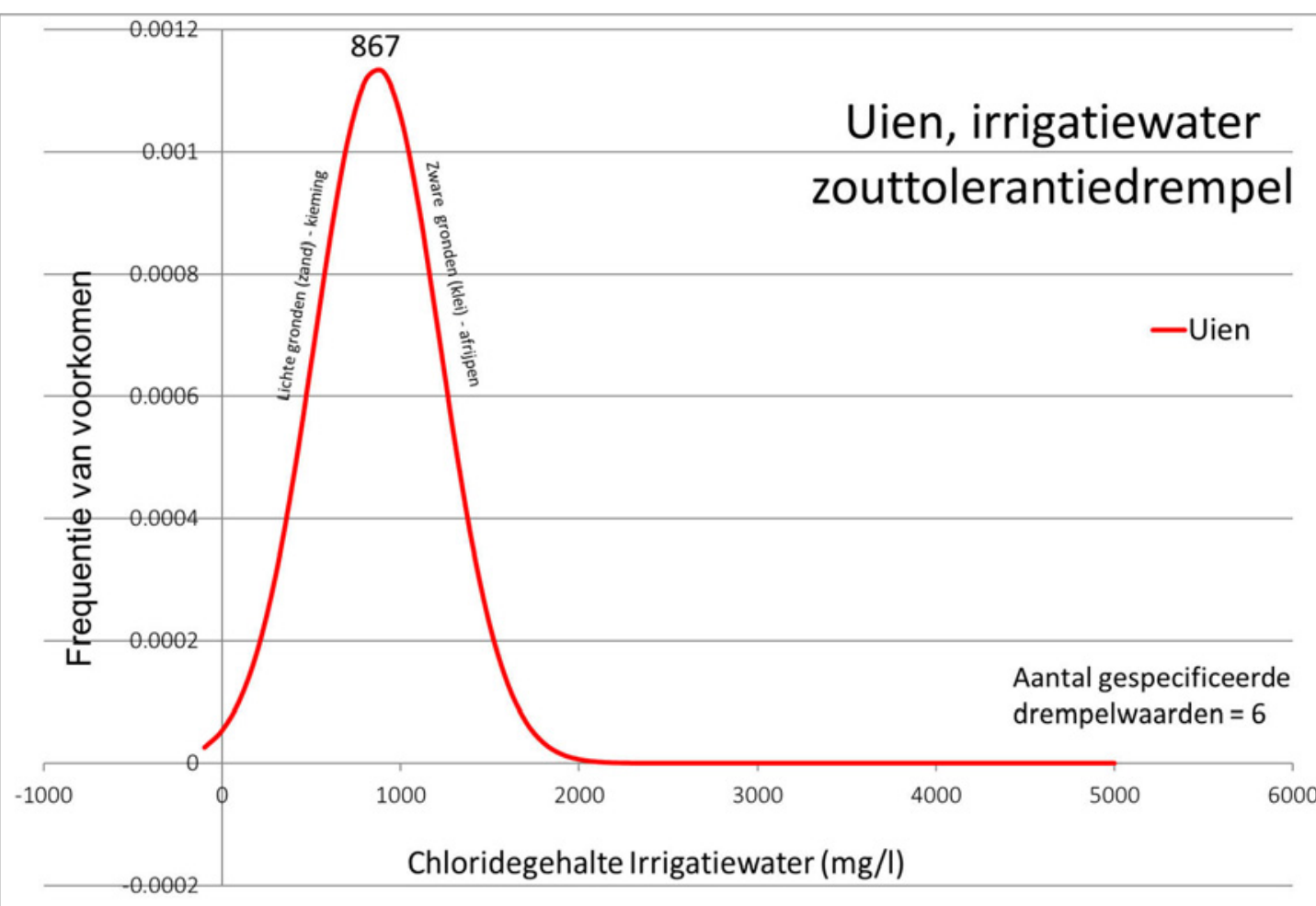

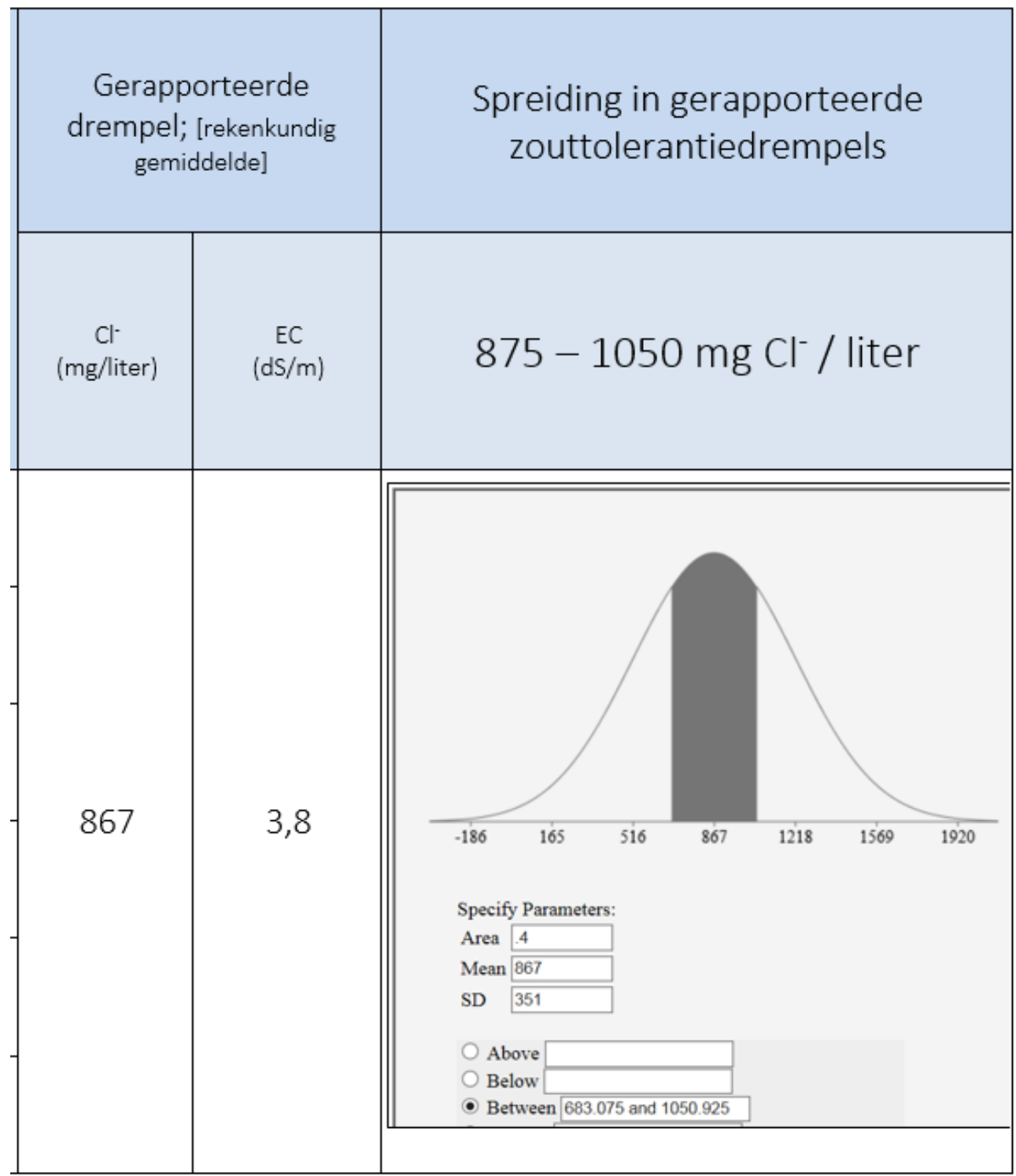




\subsection{Wortel}

\section{A. Literatuur}

Door Shannon \& Grieve (1999) is een grafiek met drempelwaarden voor zouttoleranties van diverse gewassen gepubliceerd. Voor wortel is hieruit een drempelwaarde van circa 4,1 dS/m, wat overeenkomt met $950 \mathrm{mg} / \mathrm{l} \mathrm{Cl}$.

In Alterra rapport 2201 "Actualisering Zouttolerantie" (Bakel en Stuyt, 2011) is de tabel "Risico op zoutschade aan landbouwgewassen bij verschillende zoutgehalten van beregeningswater" beschikbaar gesteld door DLV Plant, die door hen voor advisering wordt gebruikt. Ook is in dit rapport een tabel met zouttolerantiewaarden opgenomen uit het PAGV-handboek (Proefstation voor de akkerbouw en de groetenteelt in de volle grond). Voor wortel worden in deze tabellen de volgende waarden gehanteerd:

$\begin{array}{llr}\text { Bij lage tolerantie: } & \text { Bron: DLV, } & 900 \mathrm{mg} \mathrm{CL} / \mathrm{I} \\ \text { Bij hoge tolerantie: } & \text { Bron: DLV, } & 1070 \mathrm{mg} \mathrm{CL} / \mathrm{I} \\ \text { Bij lage tolerantie: } & \text { Bron: PAGV, } & 600 \mathrm{mg} \mathrm{CL/l} \\ \text { Bij hoge tolerantie: } & \text { Bron: PAGV, } & 900 \mathrm{mg} \mathrm{CL/I}\end{array}$

\section{Referenties}

Bakel, P.J.T. van en L.C.P.M. Stuyt, 2011. Actualisering van de kennis van de zouttolerantie van landbouwgewassen, op basis van literatuuronderzoek, expertkennis en praktische ervaringen. Wageningen, Alterra-rapport 2201.

Shannon, M.C. \& C.M. Grieve, 1999. Tolerance of vegetable crops to salinity. Scientia Horticulturae 78: 5-38. 


\section{B. Gegevens}

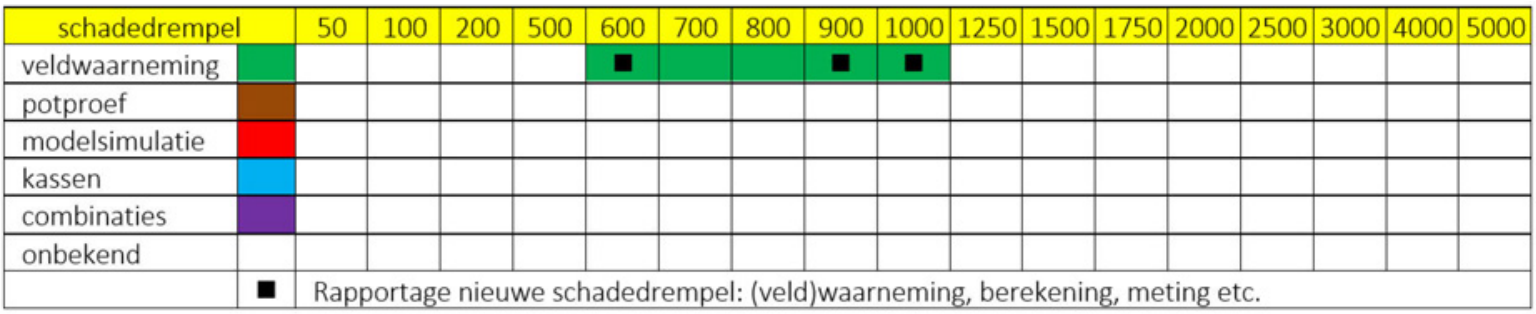

\begin{tabular}{|c|c|c|c|c|c|c|c|c|c|c|c|c|c|c|c|c|c|c|}
\hline jaar & & 1935 & 1940 & 1945 & 1950 & 1955 & 1960 & 1965 & 1970 & 1975 & 1980 & 1985 & 1990 & 1995 & 2000 & 2005 & 2010 & 2015 \\
\hline veldwaarneming & & & & & & & & & & & & & & & 뭉 & & 口 & 口 \\
\hline potproef & & & & & & & & & & & & & & & & & & \\
\hline modelsimulatie & & & & & & & & & & & & & & & & & & \\
\hline kassen & & & & & & & & & & & & & & & & & & \\
\hline combinaties & & & & & & & & & & & & & & & & & & \\
\hline onbekend & & & & & & & & & & & & & & & & & & \\
\hline
\end{tabular}

\begin{tabular}{|c|c|c|c|c|c|c|c|c|c|c|c|c|c|c|c|}
\hline No & Gewas(groep) & 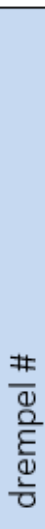 & . & 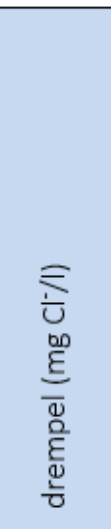 & 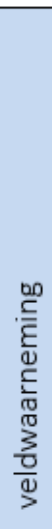 & 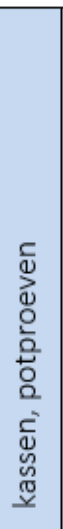 & 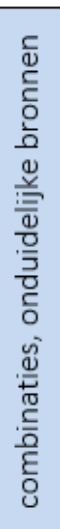 & 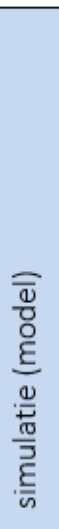 & 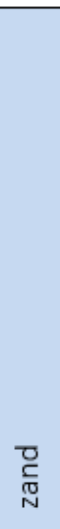 & 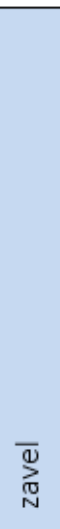 & $\frac{\bar{\alpha}}{\bar{y}}$ & 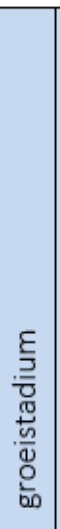 & 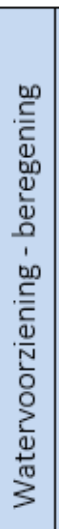 & 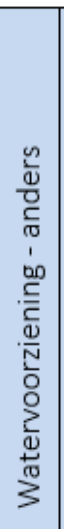 & 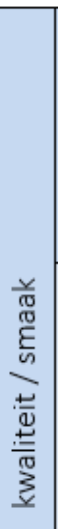 \\
\hline \multirow{6}{*}{22} & \multirow{6}{*}{ Wortel } & 1 & 1999 & 950 & $x$ & & & & & & & & & & \\
\hline & & 2 & 2011 & 1000 & $x$ & & & & & & & & & $x$ & \\
\hline & & 3 & 2015 & 900 & $x$ & & & & & & & & & $x$ & \\
\hline & & 4 & 2015 & 1070 & $x$ & & & & & & & & & $x$ & \\
\hline & & 5 & 2015 & 600 & $x$ & & & & & & & & & $x$ & \\
\hline & & 6 & 2015 & 900 & $x$ & & & & & & & & & $x$ & \\
\hline
\end{tabular}


C. Interpretatie
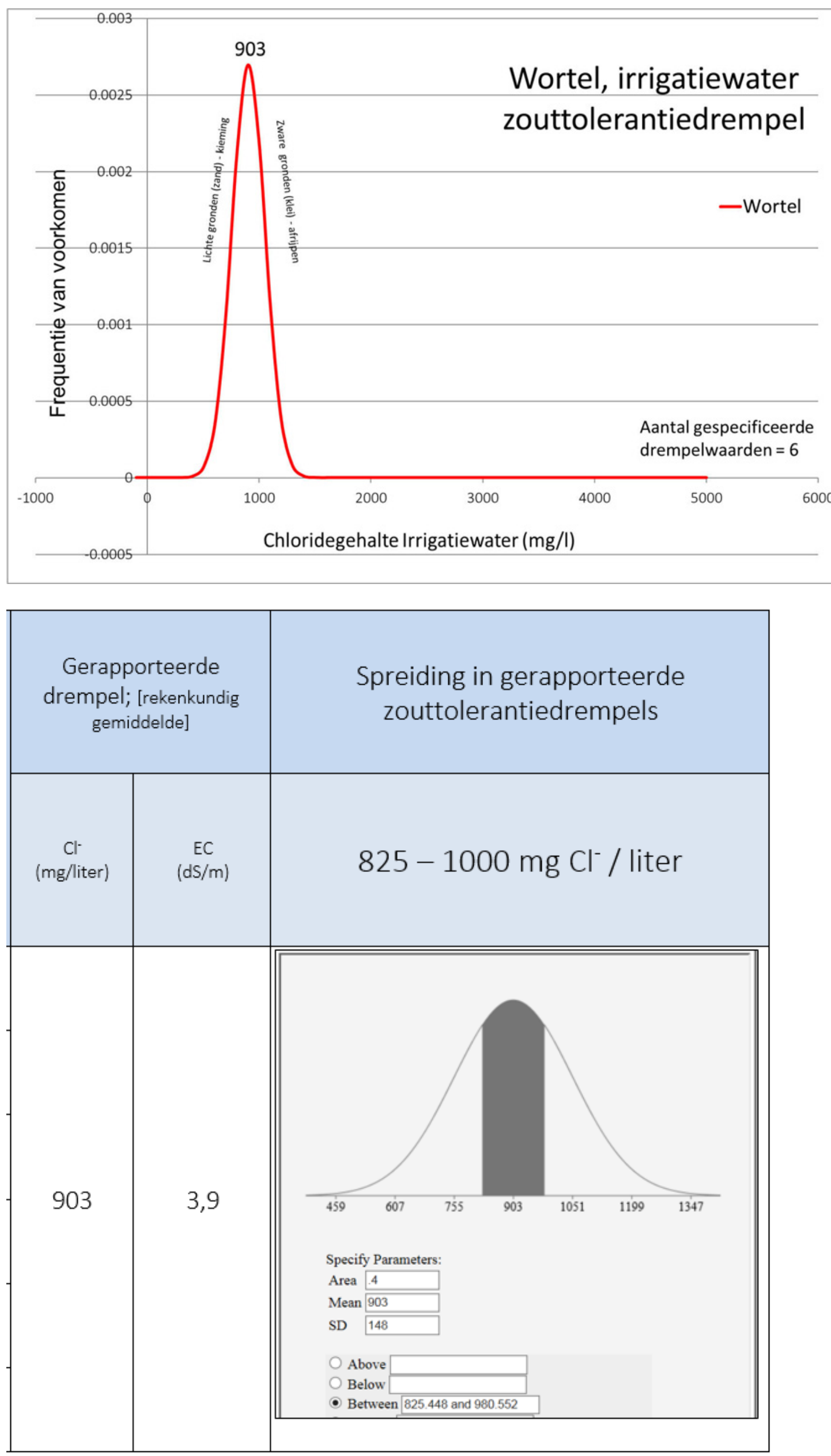


\subsection{Sierteelt}

\section{A. Literatuur}

In oudere jaarverslagen van het Instituut voor Cultuurtechniek en Waterhuishouding (ICW) en uit 1971, 1972 en 1974 worden grenswaarden voor de sierteelt genoemd van 80-210 mg/liter.

In 1983 wordt in ICW Nota 1461 (P.C. Jansen) voor het toelaatbare chloridegehalte bij sierteelt $300 \mathrm{mg} / \mathrm{l}$ vermeld.

Uit het literatuuronderzoek Actualisering Zouttolerantie van 2003 door Roest et al. ten behoeve van de ontwikkeling en het gebruik van het RIZA-instrumentarium is voor deze categorie een waarde voor het $10 \%$ gevoeligste gewas afgeleid van $69 \mathrm{mg} / \mathrm{l} \mathrm{Cl}$.

In Alterra rapport 2201 wordt door PPO een waarde van 250 mg/l Cl opgegeven als de grenswaarde voor sierteelt.

\section{Referenties}

Bakel, P.J.T. van en L.C.P.M. Stuyt, 2011. Actualisering van de kennis van de zouttolerantie van landbouwgewassen, op basis van literatuuronderzoek, expertkennis en praktische ervaringen. Wageningen, Alterra-rapport 2201.

Jansen, P.C., 1983. Waterkwaliteit. Een beknopt overzicht van begrippen, parameters, typering en normen. Instituut voor Cultuurtechniek en Waterhuishouding, ICW-Nota 1461, Wageningen. pp. 26-28.

Roest, C.W.J., P.J.T. van Bakel \&, A.A.M.F.R. Smit, 2003. Actualisering van de zouttolerantie van landen tuinbouwgewassen ten behoeve van de berekening van de zoutschade in Nederland met het RIZA-instrumentarium. Memo Alterra, Wageningen, $16 \mathrm{p}$. 


\section{B. Gegevens}

\begin{tabular}{|l|l|l|l|l|l|l|l|l|l|l|l|l|l|l|l|l|l|}
\hline schadedrempel & 50 & 100 & 200 & 500 & 600 & 700 & 800 & 900 & 1000 & 1250 & 1500 & 1750 & 2000 & 2500 & 3000 & 4000 & 5000 \\
\hline
\end{tabular} veldwaarneming

potproef

modelsimulatie

kassen

combinaties

onbekend

Rapportage nieuwe schadedrempel: (veld)waarneming, berekening, meting etc.

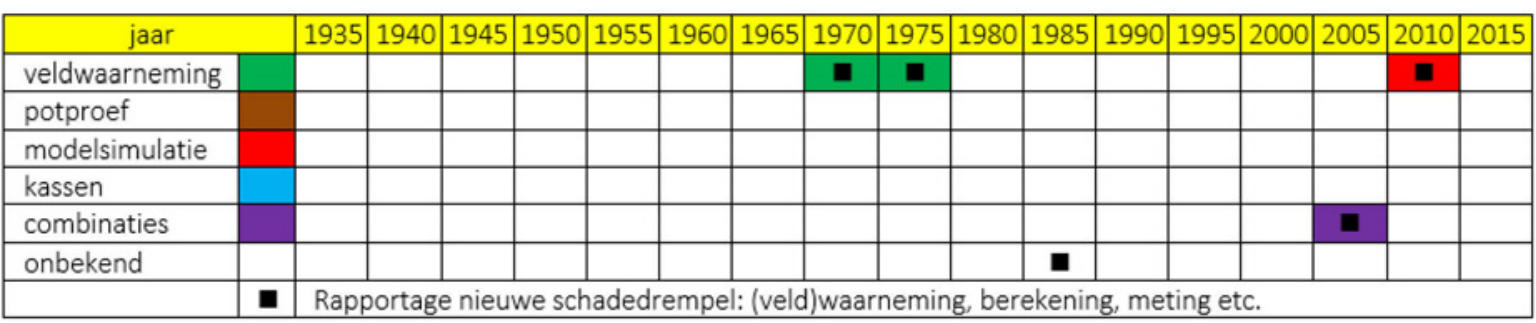

\begin{tabular}{|c|c|c|c|c|c|c|c|c|c|c|c|c|c|c|c|}
\hline No & Gewas(groep) & 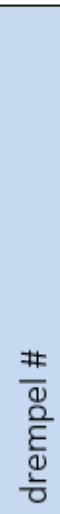 & 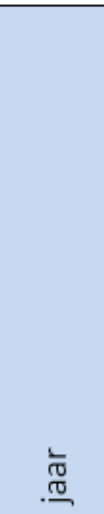 & 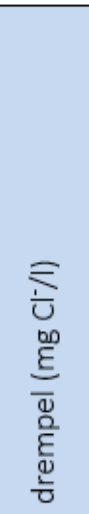 & 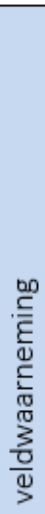 & 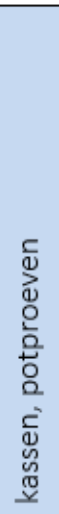 & 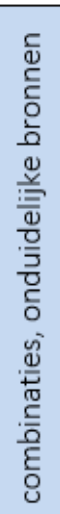 & 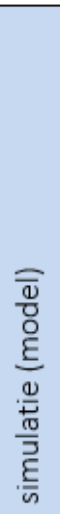 & $\begin{array}{l}\text { D } \\
\text { C } \\
\text { N }\end{array}$ & $\overline{\mathbb{N}_{N}^{0}}$ & $\frac{\bar{\omega}}{\underline{\underline{u}}}$ & 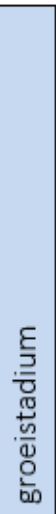 & 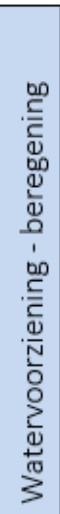 & 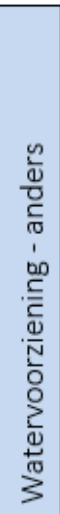 & 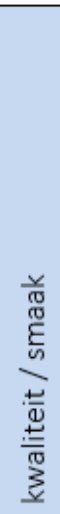 \\
\hline \multirow{11}{*}{23} & \multirow{11}{*}{ Sierteelt } & 1 & 1971 & 80 & $x$ & & & & & & & & $x$ & & \\
\hline & & 2 & 1972 & 200 & $x$ & & & & & & & & $x$ & & \\
\hline & & 3 & 1974 & 210 & $x$ & & & & & & & & $x$ & & \\
\hline & & 4 & 1983 & 300 & $x$ & & & & & & & & $x$ & & \\
\hline & & 5 & 2003 & 101 & & & $x$ & & & & & & & & \\
\hline & & 6 & 2003 & 69 & & & $\times$ & & & & & & & & \\
\hline & & 7 & 2003 & 75 & & & $x$ & & & & & & & & \\
\hline & & 8 & 2009 & 50 & & & $\times$ & & $x$ & & & & & & \\
\hline & & 9 & 2009 & 100 & & & $x$ & & & & $x$ & & & & \\
\hline & & 10 & 2009 & 200 & & & $\times$ & & & $x$ & & & & & \\
\hline & & 11 & 2011 & 250 & $x$ & & & & & & & & & & \\
\hline
\end{tabular}


C. Interpretatie

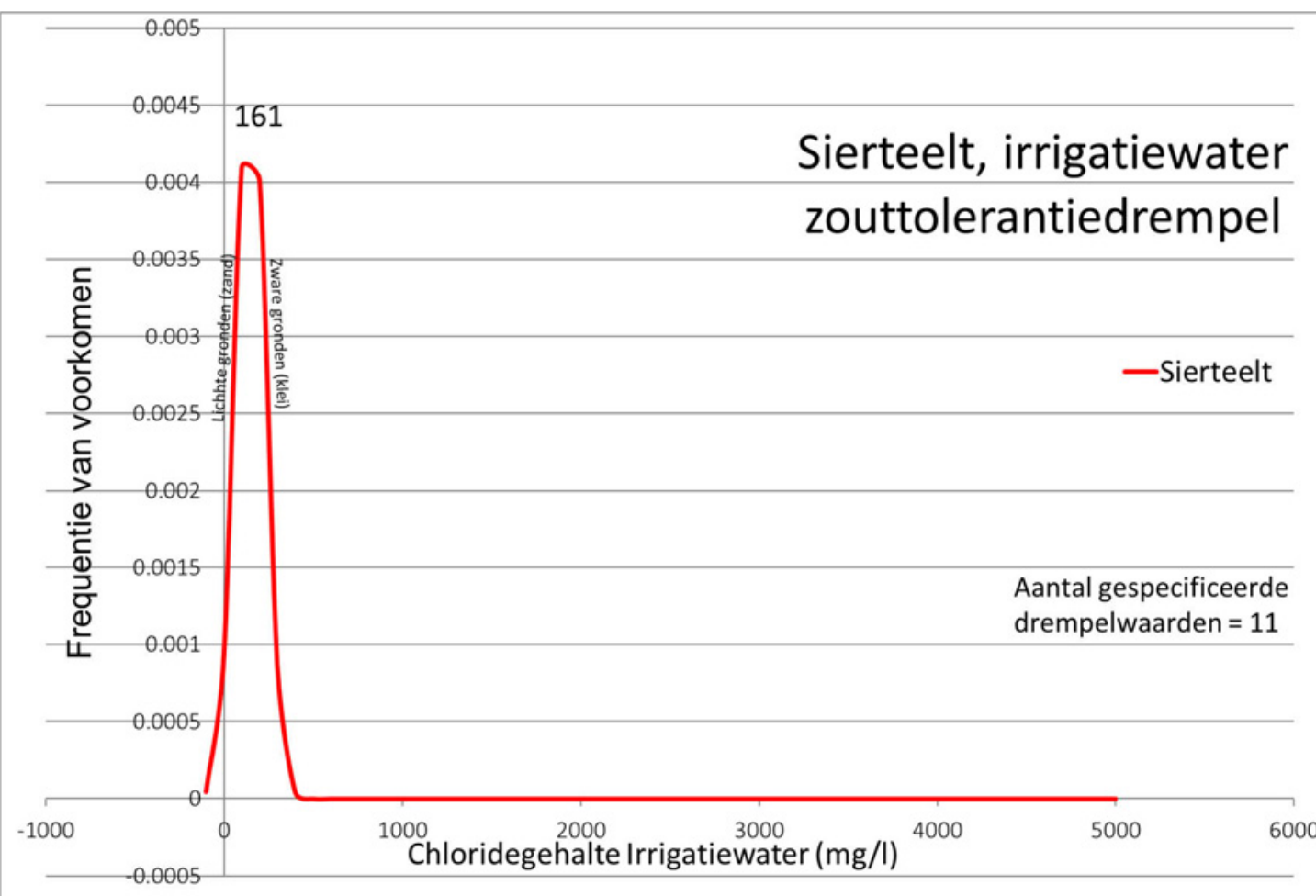

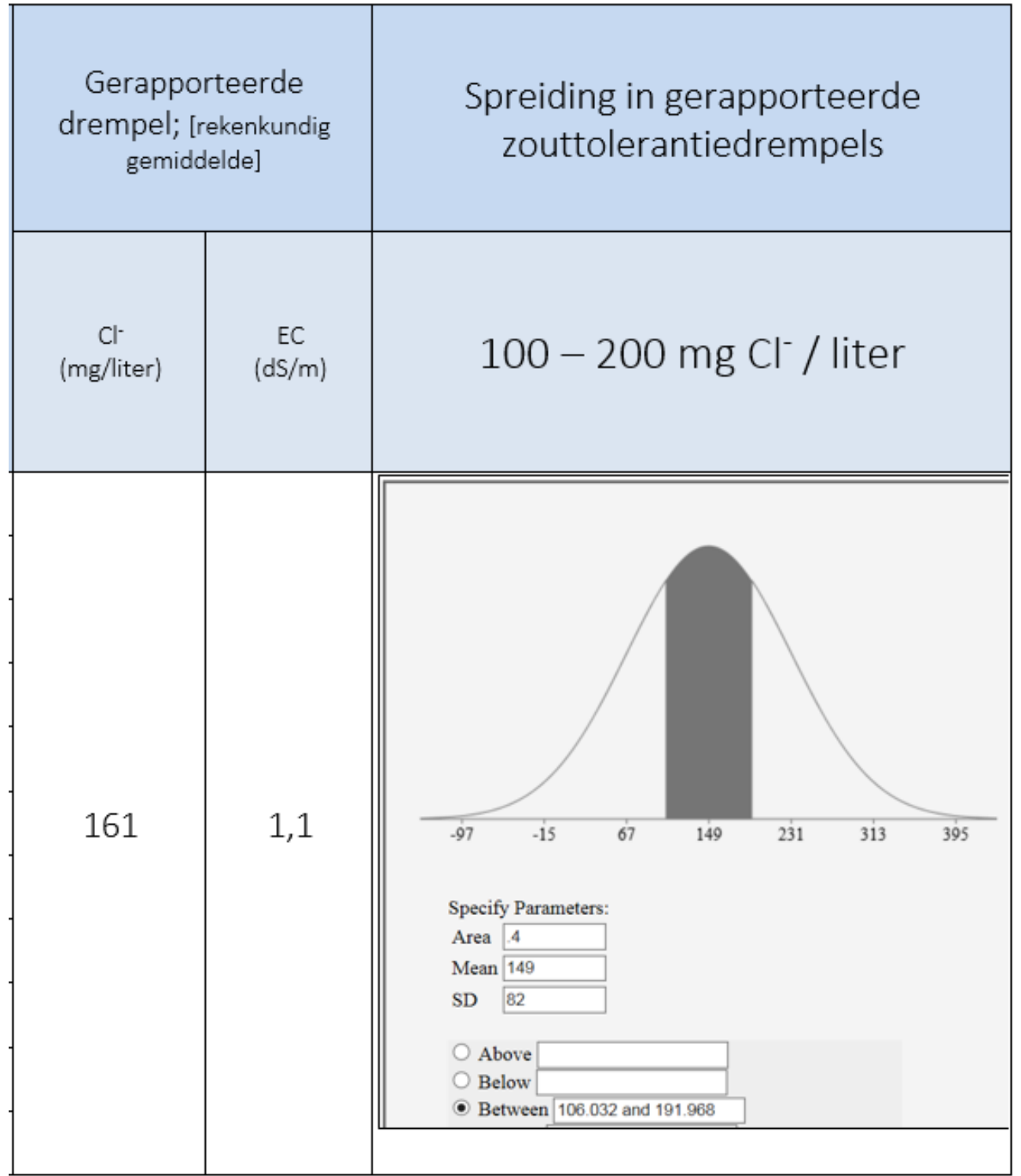




\subsection{Amaryllis, Chrysant}

\section{A. Literatuur}

In 1983 wordt in ICW Nota 1461 (P.C. Jansen) voor het toelaatbare chloridegehalte bij dit gewas $300 \mathrm{mg} / \mathrm{l}$ vermeld.

Uit het literatuuronderzoek "Actualisering Zouttolerantie" van 2003 door Roest et al. ten behoeve van de ontwikkeling en het gebruik van het RIZA-instrumentarium is voor deze categorie een waarde voor het $10 \%$ gevoeligste gewas afgeleid, te weten $33 \mathrm{mg} / \mathrm{l} \mathrm{Cl}$.

\section{Referenties}

Jansen, P.C., 1983. Waterkwaliteit. Een beknopt overzicht van begrippen, parameters, typering en normen. Instituut voor Cultuurtechniek en Waterhuishouding, ICW-Nota 1461, Wageningen. pp. 26-28.

Roest, C.W.J., P.J.T. van Bakel \&, A.A.M.F.R. Smit, 2003. Actualisering van de zouttolerantie van landen tuinbouwgewassen ten behoeve van de berekening van de zoutschade in Nederland met het RIZA-instrumentarium. Memo Alterra, Wageningen, $16 \mathrm{p}$. 


\section{B. Gegevens}

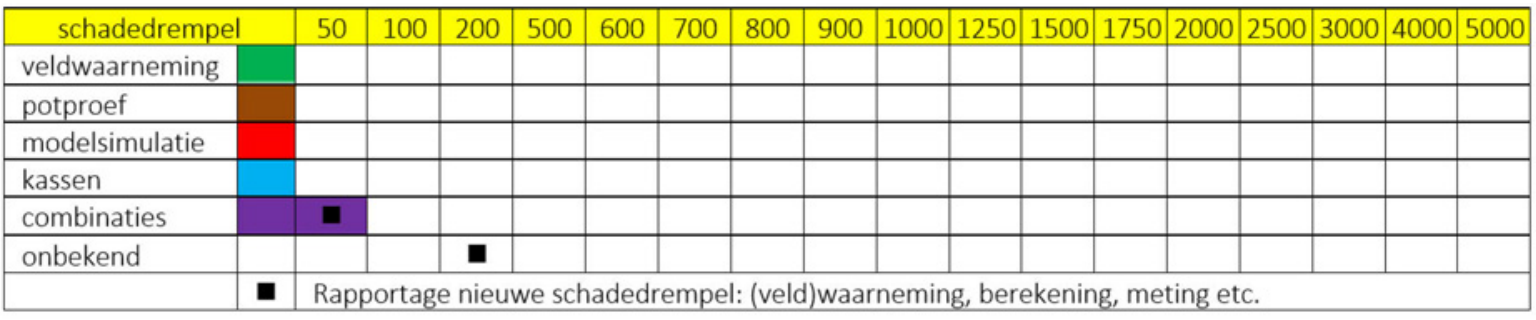

\begin{tabular}{|c|c|c|c|c|c|c|c|c|c|c|c|c|c|c|c|c|c|c|}
\hline jaar & & 1935 & 1940 & 1945 & 1950 & 1955 & 1960 & 1965 & 1970 & 1975 & 1980 & 1985 & 1990 & 1995 & 2000 & 2005 & 2010 & 2015 \\
\hline veldwaarneming & & & & & & & & & & & & & & & & & & \\
\hline potproef & & & & & & & & & & & & & & & & & & \\
\hline modelsimulatie & & & & & & & & & & & & & & & & & & \\
\hline kassen & & & & & & & & & & & & & & & & & & \\
\hline combinaties & & & & & & & & & & & & & & & & 무 & & \\
\hline onbekend & & & & & & & & & & & & a & & & & & & \\
\hline & $\mathbf{\square}$ & Rapp & ortage & e nieuv & we sch & adedr & rempel & I: (veld & waar & nemin & $\mathrm{g}$, bere & ekenin & $\mathrm{g}$, met & ting etc & & & & \\
\hline
\end{tabular}

\begin{tabular}{|c|c|c|c|c|c|c|c|c|c|c|c|c|c|c|c|}
\hline No & Gewas(groep) & 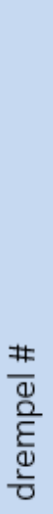 & . & 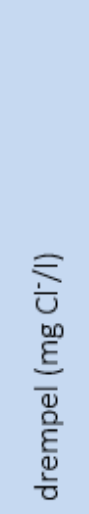 & 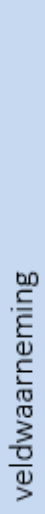 & 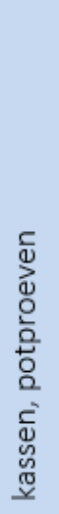 & 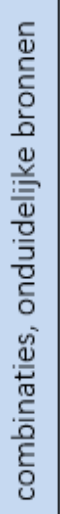 & 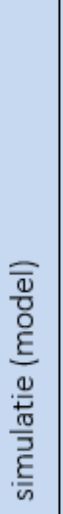 & $\underset{\substack{\text { T. } \\
\text { N }}}{ }$ & 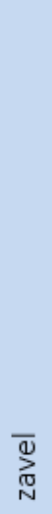 & $\frac{\bar{\omega}}{\underline{x}}$ & 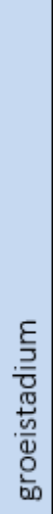 & 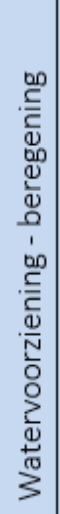 & 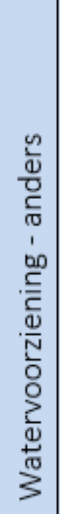 & 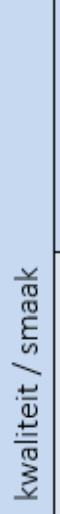 \\
\hline \multirow{4}{*}{24} & \multirow{4}{*}{$\begin{array}{c}\text { Amaryllis, } \\
\text { Chrysant }\end{array}$} & 1 & 1983 & 300 & $x$ & & & & & & & & $x$ & & \\
\hline & & 2 & 2003 & 41 & & & $x$ & & $x$ & & & & $x$ & & \\
\hline & & 3 & 2003 & 33 & & & $x$ & & & & $x$ & & $x$ & & \\
\hline & & 4 & 2003 & 50 & & & $x$ & & & $x$ & & & $\times$ & & \\
\hline
\end{tabular}


C. Interpretatie

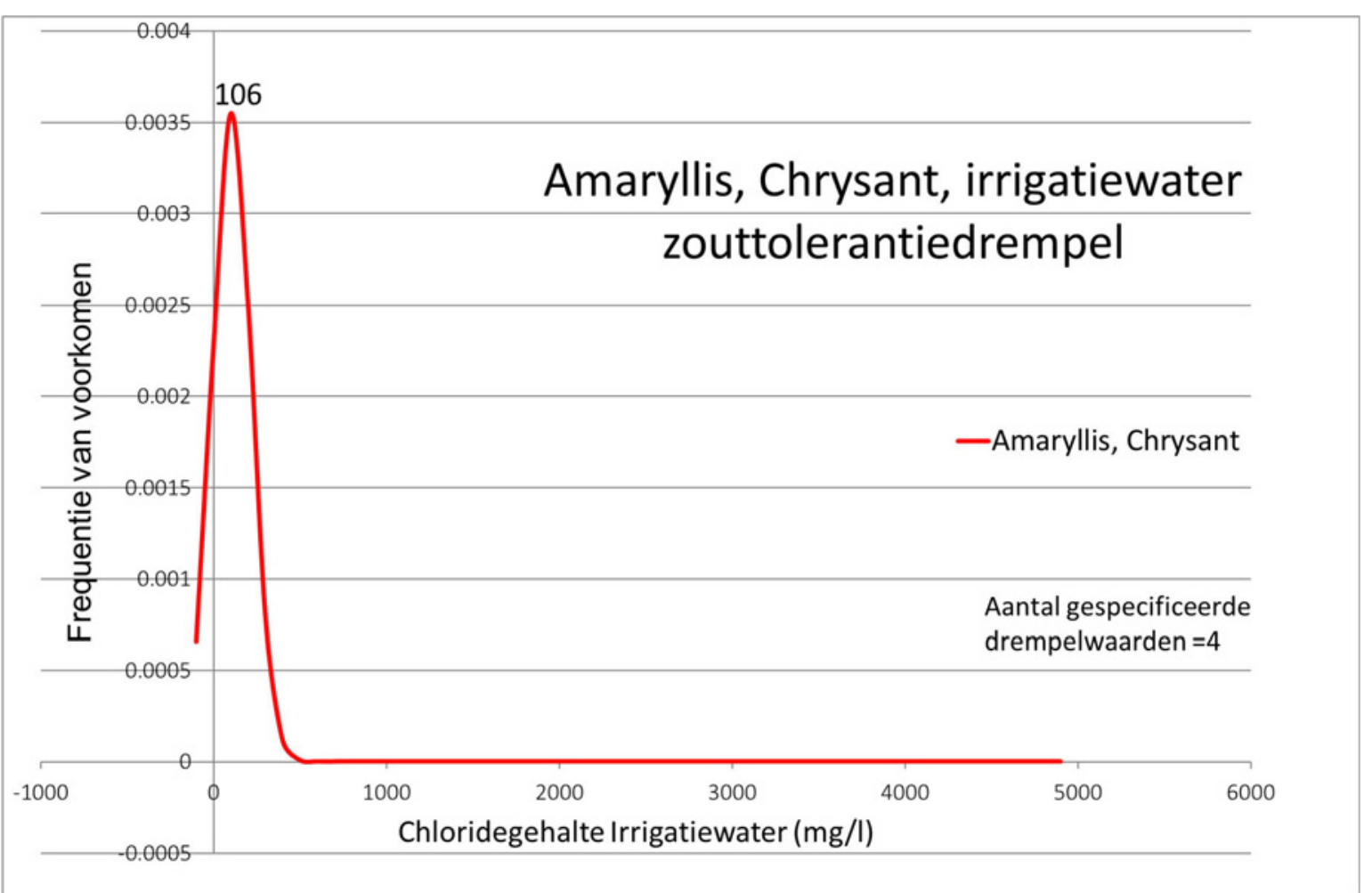

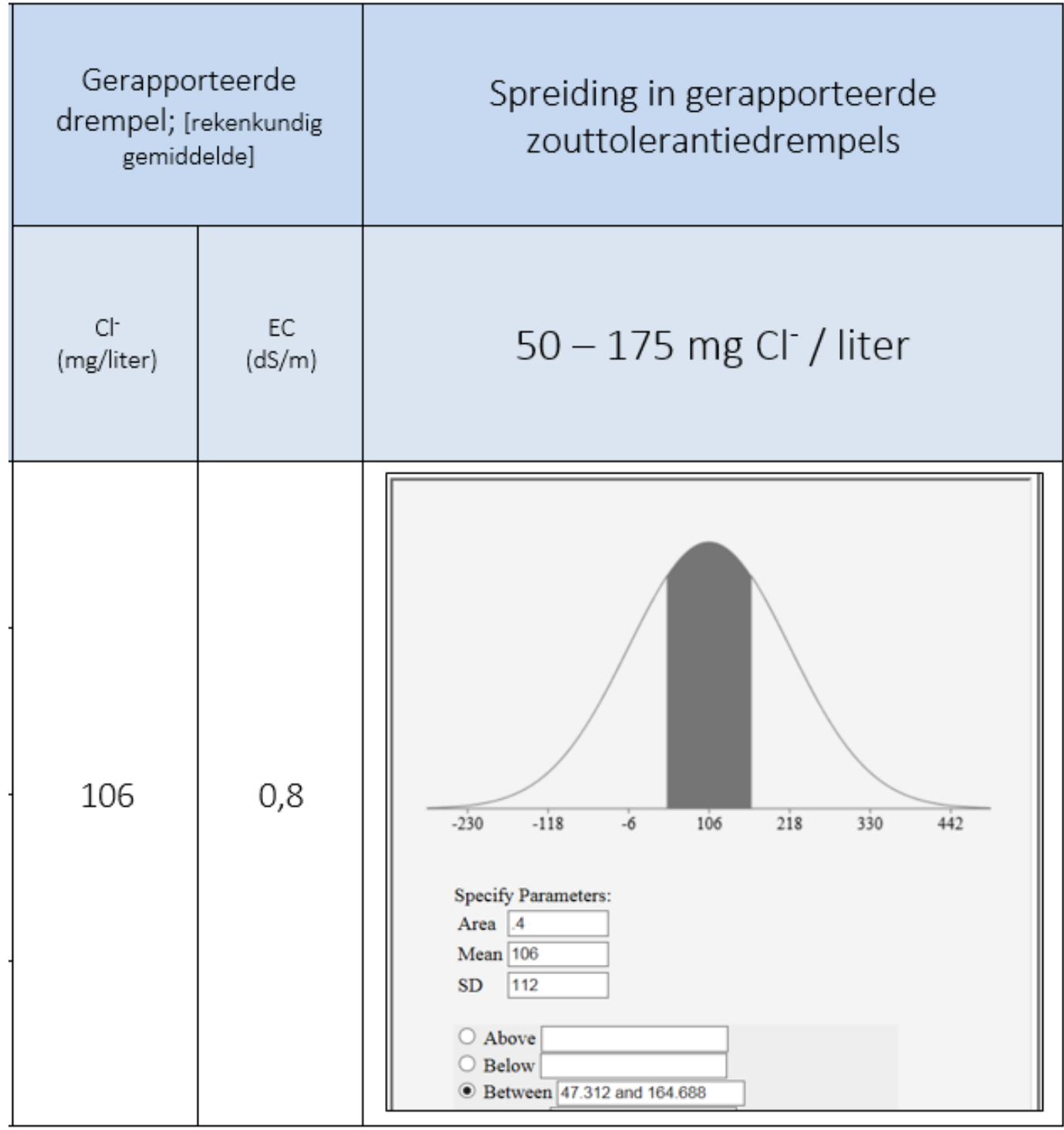




\subsection{Bollentelers Noord-Holland}

\section{A. Literatuur}

In Alterra rapport 2201 specificeert PPO een waarde van $250 \mathrm{mg} / \mathrm{l} \mathrm{Cl}$ als drempelwaarde van beregeningswater voor bollen in Noord-Holland.

Eurofins (2015a) categoriseert bloembollen als 'matig gevoelig akkerbouwgewas', met een chloridedrempel van 600-900 $\mathrm{mg} \mathrm{Cl} / \mathrm{l}$, maar de bron van deze informatie kon niet worden achterhaald en betreft geen eigen onderzoek.

\section{Referenties}

Bakel, P.J.T. van en L.C.P.M. Stuyt, 2011. Actualisering van de kennis van de zouttolerantie van landbouwgewassen, op basis van literatuuronderzoek, expertkennis en praktische ervaringen. Wageningen, Alterra-rapport 2201.

Eurofins, 2015a. Waterkwaliteit in de akkerbouw. Bijlage/Toelichting. Eurofins Agro Laboratories, Wageningen.

\section{B. Gegevens}

\begin{tabular}{|c|c|c|c|c|c|c|c|c|c|c|c|c|c|c|c|c|c|c|}
\hline schadedrempel & & 50 & 100 & 200 & 500 & 600 & 700 & 800 & 900 & 1000 & 1250 & 1500 & 1750 & 2000 & 2500 & 3000 & 4000 & 5000 \\
\hline veldwaarneming & & & & 口 & & & & & & & & & & & & & & \\
\hline potproef & & & & & & & & & & & & & & & & & & \\
\hline modelsimulatie & & & & & & & & & & & & & & & & & & \\
\hline kassen & & & & & & & & & & & & & & & & & & \\
\hline combinaties & & & & & & & & & & & & & & & & & & \\
\hline onbekend & & & & & & & & & & & & & & & & & & \\
\hline & - & Rap & ort & ni & e & ade & $\mathrm{mp}$ & : (ve & wa: & nemi & g, b & eker & , n & ting & & & & \\
\hline
\end{tabular}

\begin{tabular}{|c|c|c|c|c|c|c|c|c|c|c|c|c|c|c|c|c|c|c|}
\hline jaar & & 1935 & 1940 & 1945 & 1950 & 1955 & 1960 & 1965 & 1970 & 1975 & \begin{tabular}{|l|l|}
1980 \\
\end{tabular} & 1985 & 1990 & 1995 & 2000 & 2005 & 2010 & 2015 \\
\hline veldwaarneming & & & & & & & & & & & & & & & & & 口 & \\
\hline potproef & & & & & & & & & & & & & & & & & & \\
\hline modelsimulatie & & & & & & & & & & & & & & & & & & \\
\hline kassen & & & & & & & & & & & & & & & & & & \\
\hline combinaties & & & & & & & & & & & & & & & & & & \\
\hline onbekend & & & & & & & & & & & & & & & & & & \\
\hline & - & Rappo & ortage & e nieun & & ladec & rempel: & : (veld & d)waarr & neming & g, bere & ekening & g, met & ting etc & & & & \\
\hline
\end{tabular}

\begin{tabular}{|c|c|c|c|c|c|c|c|c|c|c|c|c|c|c|c|}
\hline No & Gewas(groep) & 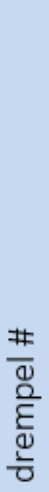 & 离 & 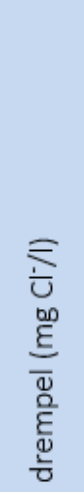 & 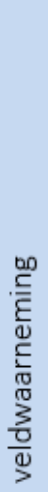 & 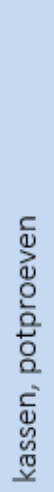 & 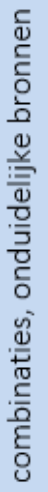 & 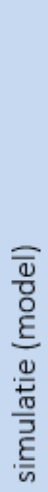 & $\begin{array}{l}\text { D } \\
\text { N } \\
\text { N }\end{array}$ & 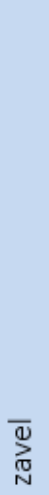 & $\frac{\bar{\alpha}}{\bar{x}}$ & 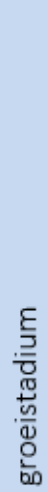 & 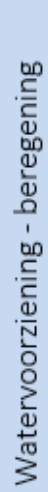 & 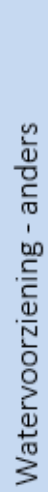 & 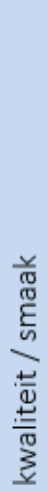 \\
\hline 25 & $\begin{array}{r}\text { Bollentelers } \\
\text { Noord Holland }\end{array}$ & 1 & 2011 & 200 & $\times$ & & & & $\times$ & & & & & & \\
\hline
\end{tabular}




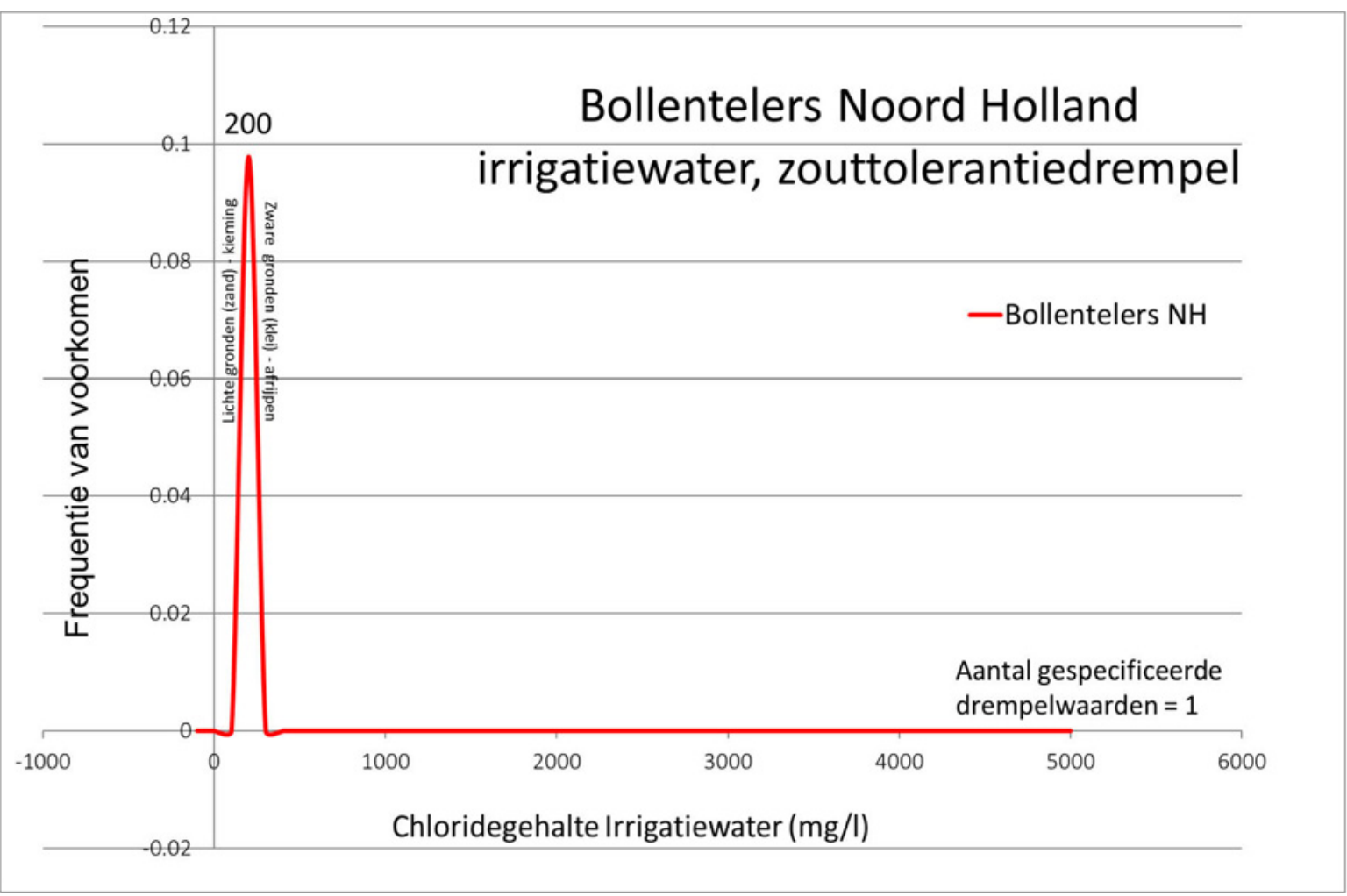

\begin{tabular}{|c|c|c|}
\hline \multicolumn{2}{|c|}{$\begin{array}{c}\text { Gerapporteerde } \\
\text { drempel; [rekenkundig } \\
\text { gemiddelde] }\end{array}$} & $\begin{array}{c}\text { Spreiding in gerapporteerde } \\
\text { zouttolerantiedrempels }\end{array}$ \\
\hline $\begin{array}{c}\mathrm{Cl}^{-} \\
\text {(mg/liter) }\end{array}$ & $\begin{array}{c}\mathrm{EC} \\
\text { (dS/m) }\end{array}$ & -- \\
\hline 200 & 1,3 & \\
\hline
\end{tabular}




\subsection{Boomkwekerij}

\section{A. Literatuur}

In het Jaarverslag van het Instituut voor Cultuurtechniek en Waterhuishouding (ICW) van 1970 worden resultaten vermeld van literatuuronderzoek en praktijkervaring in de boomkwekerijteelt, en is getracht hieruit normen op te stellen voor gietwater. Hieruit is een waarde voortgekomen van $150 \mathrm{mg} / \mathrm{l} \mathrm{Cl}$.

In 1983 wordt in ICW Nota 1461 (P.C. Jansen) 300 mg/l vermeld voor het toelaatbare chloridegehalte voor boomkwekerijen.

In het Alterra rapport 2201 wordt door PPO Lisse een waarde van $250 \mathrm{mg} / \mathrm{l} \mathrm{Cl}$ opgegeven als de grenswaarde boomkwekerijen.

Schipper en van der Staak (2011), werkzaam bij DLV Plant in respectievelijk Boskoop en Boxtel, koppelen kwaliteitsnormen voor gietwater in de boomkwekerij aan drie categorieën toepassingen, gecombineerd aan de zoutgevoeligheid van teelten: (1) vermeerdering en zoutgevoelige kasteelt, (2) recirculatie, zoutgevoelige buitenteelt en niet-zoutgevoelige kasteelt, en (3) niet-gevoelige buitenteelt. Zij geven voor gietwater diverse 'zoutcriteria': voor geleidbaarheid, uitgedrukt in EC $(\mathrm{mS} / \mathrm{cm})$, en, daarnaast apart voor chloor en natrium, beide in $\mathrm{mmol} / \mathrm{l}$. Vertaald in $\mathrm{mg} / \mathrm{l}$ specificeren zij: voor de EC, voor respectievelijk (1), (2) en (3): 60, 115 en $200 \mathrm{mg} / \mathrm{l}$, voor chloor 23, 60 en $115 \mathrm{mg} / \mathrm{l}$ en voor natrium 20, 90 en $180 \mathrm{mg} / \mathrm{l}$. Auteurs geven een serie waardevolle richtlijnen en tips voor telers, met behulp waarvan hun 'waterbewustzijn' in praktijksituaties wordt vergroot. Bronnen waarop de gespecificeerde normen zijn gebaseerd worden niet genoemd.

In een informatieblad van Eurofins (2015b) wordt voor de waterkwaliteit voor boomkwekerijen een waarde van $60 \mathrm{mg} / \mathrm{l} \mathrm{Cl}$ gespecificeerd. De bron(nen) van de in dit informatieblad gespecificeerde grenswaarde $(n)$ konden - ondanks gerichte navraag - niet worden achterhaald.

\section{Referenties}

Bakel, P.J.T. van en L.C.P.M. Stuyt, 2011. Actualisering van de kennis van de zouttolerantie van landbouwgewassen, op basis van literatuuronderzoek, expertkennis en praktische ervaringen. Wageningen, Alterra-rapport 2201.

Eurofins, 2015b. Waterkwaliteit in de boomkwekerij. Bijlage/Toelichting. Eurofins Agro Laboratories, Wageningen.

ICW, 1970. Jaarverslag van het Instituut voor Cultuurtechniek en Waterhuishouding (ICW) van het instituut voor cultuurtechniek en waterhuishouding, Wageningen.

Jansen, P.C., 1983. Waterkwaliteit. Een beknopt overzicht van begrippen, parameters, typering en normen. Instituut voor Cultuurtechniek en Waterhuishouding, ICW-Nota 1461, Wageningen. pp. 26-28. 


\section{B. Gegevens}

\begin{tabular}{|c|c|c|c|c|c|c|c|c|c|c|c|c|c|c|c|c|c|c|}
\hline schadedrempel & & 50 & 100 & 200 & 500 & 600 & 700 & 800 & 900 & 1000 & 1250 & 1500 & 1750 & 2000 & 2500 & 3000 & 4000 & 5000 \\
\hline veldwaarneming & & & घ & 口 & & & & & & & & & & & & & & \\
\hline \multicolumn{19}{|l|}{ potproef } \\
\hline \multicolumn{19}{|l|}{ modelsimulatie } \\
\hline \multicolumn{19}{|l|}{ kassen } \\
\hline \multicolumn{19}{|l|}{ combinaties } \\
\hline onbekend & & & & - & & & & & & & & & & & & & & \\
\hline & $\mathbf{a}$ & Rapp & orta & e nie & wes & adedr & empel & I: (veld & ) waar! & rnemin & ig, bere & rekenin & $\mathrm{ng}$, met & ting etc & & & & \\
\hline
\end{tabular}

\begin{tabular}{|c|c|c|c|c|c|c|c|c|c|c|c|c|c|c|c|c|c|}
\hline jaar & 1935 & 1940 & 1945 & 1950 & 1955 & 1960 & 1965 & 1970 & 1975 & 1980 & 1985 & 1990 & 1995 & 2000 & 2005 & 2010 & 2015 \\
\hline veldwaarneming & & & & & & & & a & & & & & & & & 口 & \\
\hline potproef & & & & & & & & & & & & & & & & & \\
\hline modelsimulatie & & & & & & & & & & & & & & & & & \\
\hline kassen & & & & & & & & & & & & & & & & & \\
\hline combinaties & & & & & & & & & & & & & & & & & \\
\hline onbekend & & & & & & & & & & & - & & & & & & \\
\hline
\end{tabular}

\begin{tabular}{|c|c|c|c|c|c|c|c|c|c|c|c|c|c|c|c|}
\hline No & Gewas(groep) & 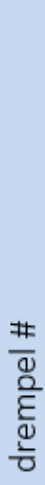 & 离 & 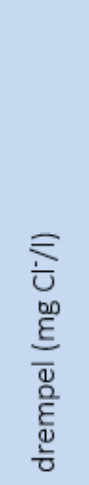 & 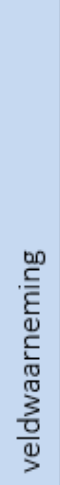 & 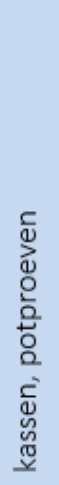 & 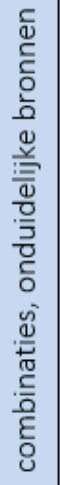 & 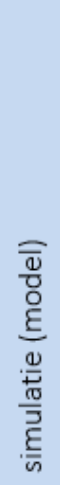 & 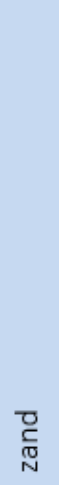 & 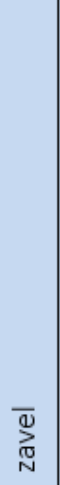 & $\frac{\bar{\omega}}{\underline{y}}$ & 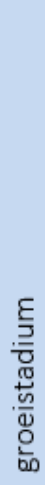 & 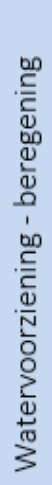 & 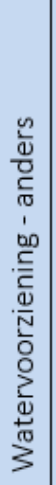 & 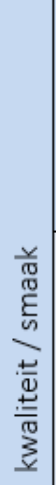 \\
\hline \multirow{3}{*}{26} & \multirow{3}{*}{ Boomkwekerij } & 1 & 1970 & 150 & $x$ & & & & & & & & $\times$ & & \\
\hline & & 2 & 1983 & 300 & $x$ & & & & & & & & $x$ & & \\
\hline & & 3 & 2011 & 250 & $x$ & & & & & & & & $\times$ & & \\
\hline
\end{tabular}


C. Interpretatie
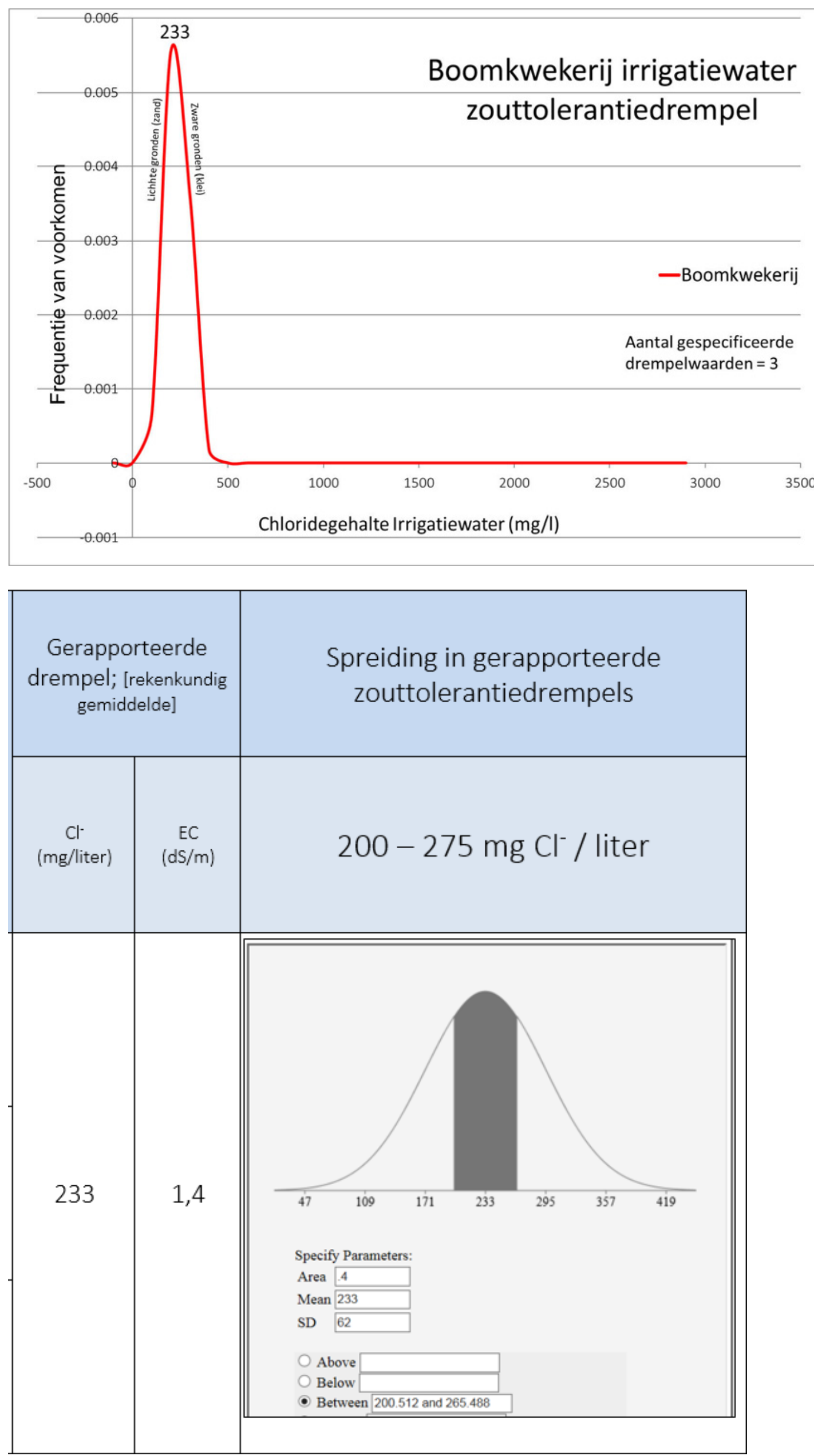


\subsection{Tulpen}

\section{A. Literatuur}

In 1983 wordt in ICW Nota 1461 (P.C. Jansen) 300 mg/l vermeld voor het toelaatbare chloridegehalte van beregeningswater bij tulpen.

Door het IKC-AT, Afdeling Bloembollen, wordt in 1993 voor beregening van bloembolgewassen in de Flevopolders $600 \mathrm{mg} / \mathrm{l}$ en op zavel en lichte kleigrond $1500 \mathrm{mg} / \mathrm{l} \mathrm{Cl}$ als schadegrens genoemd (Bakel en Stuyt, 2011).

In 1998 heeft J. Huinink in publicatie "Het economisch belang van water in de landbouw", uitgegeven door het toenmalige Informatie en Kennis Centrum Landbouw (IKC) een waarde vermeld van $200 \mathrm{mg} / \mathrm{l} \mathrm{Cl}$.

In 2009 werd de studie "Review of crop salt tolerance in the Netherlands" uitgevoerd (Bakel et al., 2009). In dit project zijn met behulp van het computersimulatiemodel SWAP (Wageningen UR-Alterra) de volgende drempelwaarden voor $0 \%$ gewasschade voor tulpen op twee verschillende bodems in het droogste jaar 1976 vastgesteld: $100 \mathrm{mg} / \mathrm{l} \mathrm{Cl}$ voor zandgrond en $150 \mathrm{mg} / \mathrm{l}$ voor zavelgrond. Omdat tulpen op kleigrond niet gebruikelijk was is dit toen niet gemodelleerd (Alterra-rapport 1926).

\section{Referenties}

Bakel, P.J.T. van en L.C.P.M. Stuyt, 2011. Actualisering van de kennis van de zouttolerantie van landbouwgewassen, op basis van literatuuronderzoek, expertkennis en praktische ervaringen. Wageningen, Alterra-rapport 2201.

Bakel P.J.T., R.A.L. Kselik, C.W.J. Roest en A.A.M.F.R. Smit. 2009. Review of crop salt tolerance in the Netherlands. Rapport 1926, Alterra, Wageningen.

Huinink, J.T.M., 1998. Het economisch belang van water in de landbouw. Rapport Informatie- en Kennis Centrum Landbouw (IKC-Landbouw), Ede, p 26-27.

Jansen, P.C., 1983. Waterkwaliteit. Een beknopt overzicht van begrippen, parameters, typering en normen. Instituut voor Cultuurtechniek en Waterhuishouding, ICW-Nota 1461, Wageningen. pp. 26-28. 


\section{B. Gegevens}

\begin{tabular}{|l|l|l|l|l|l|l|l|l|l|l|l|l|l|l|l|l|l|}
\hline schadedrempel & 50 & 100 & 200 & 500 & 600 & 700 & 800 & 900 & 1000 & 1250 & 1500 & 1750 & 2000 & 2500 & 3000 & 4000 & 5000 \\
\hline
\end{tabular}

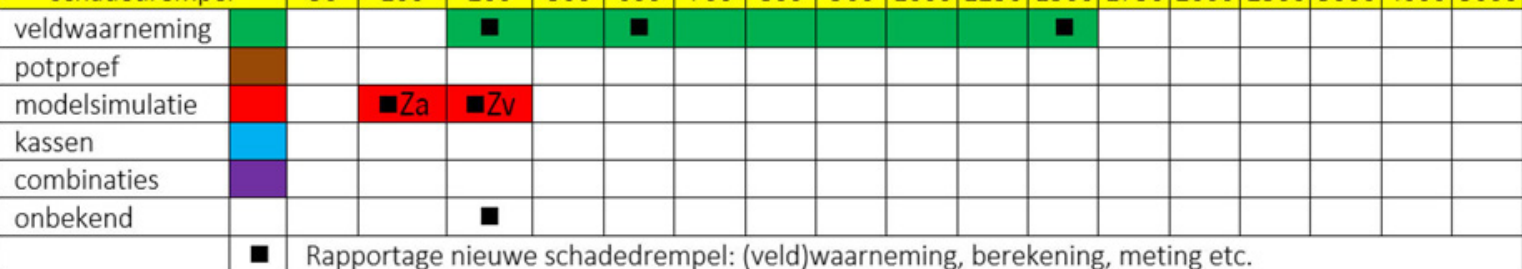

\begin{tabular}{|c|c|c|c|c|c|c|c|c|c|c|c|c|c|c|c|c|c|c|}
\hline jaar & & 1935 & 1940 & 1945 & 1950 & 1955 & 1960 & 1965 & 1970 & 1975 & 1980 & 1985 & 1990 & 1995 & 2000 & 2005 & 2010 & 2015 \\
\hline veldwaarneming & & & & & & & & & & & & $\mathbf{a}$ & & $\mathbf{a}$ & 口 & & & \\
\hline potproef & & & & & & & & & & & & & & & & & & \\
\hline kassen & & & & & & & & & & & & & & & & & & \\
\hline combinaties & & & & & & & & & & & & & & & & & & \\
\hline onbekend & & & & & & & & & & & & $\mathbf{a}$ & & & & & & \\
\hline
\end{tabular}

\begin{tabular}{|c|c|c|c|c|c|c|c|c|c|c|c|c|c|c|c|}
\hline No & Gewas(groep) & 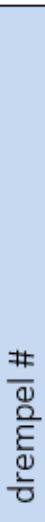 & $\begin{array}{l}\stackrel{1}{0} \\
\stackrel{\pi}{0}\end{array}$ & 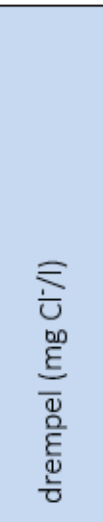 & 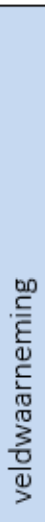 & 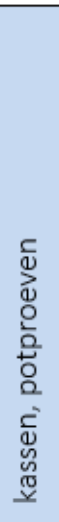 & 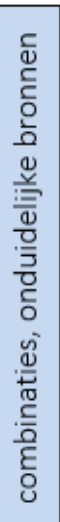 & $\begin{array}{l}\overline{\bar{v}} \\
\overline{0} \\
\underline{\underline{\xi}} \\
\frac{0}{0} \\
\frac{0}{3} \\
\frac{E}{n}\end{array}$ & 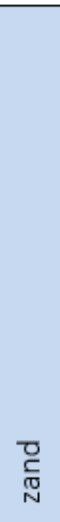 & 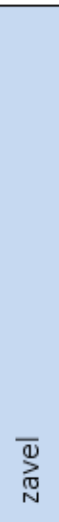 & $\frac{\overline{\bar{\omega}}}{\underline{\underline{y}}}$ & 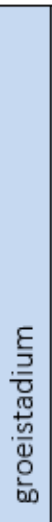 & 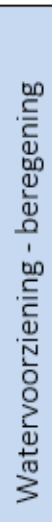 & $\begin{array}{l}\frac{0}{0} \\
\frac{0}{0} \\
\frac{0}{\pi} \\
1 \\
0 \\
\frac{c}{5} \\
\frac{0}{N} \\
0 \\
0 \\
\frac{2}{0} \\
\frac{0}{\pi} \\
3\end{array}$ & 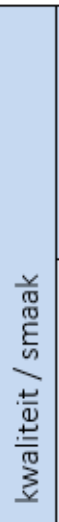 \\
\hline \multirow{4}{*}{27} & \multirow{4}{*}{ Tulpen } & 1 & 1983 & 300 & $x$ & & & & $x$ & & & & $x$ & & \\
\hline & & 2 & 1993 & 600 & $x$ & & & & $x$ & & & & & & \\
\hline & & 3 & 1993 & 1500 & $x$ & & & & & $x$ & $x$ & & & & \\
\hline & & 4 & 1998 & 200 & $x$ & & & & & & & & $x$ & & \\
\hline
\end{tabular}


C. Interpretatie
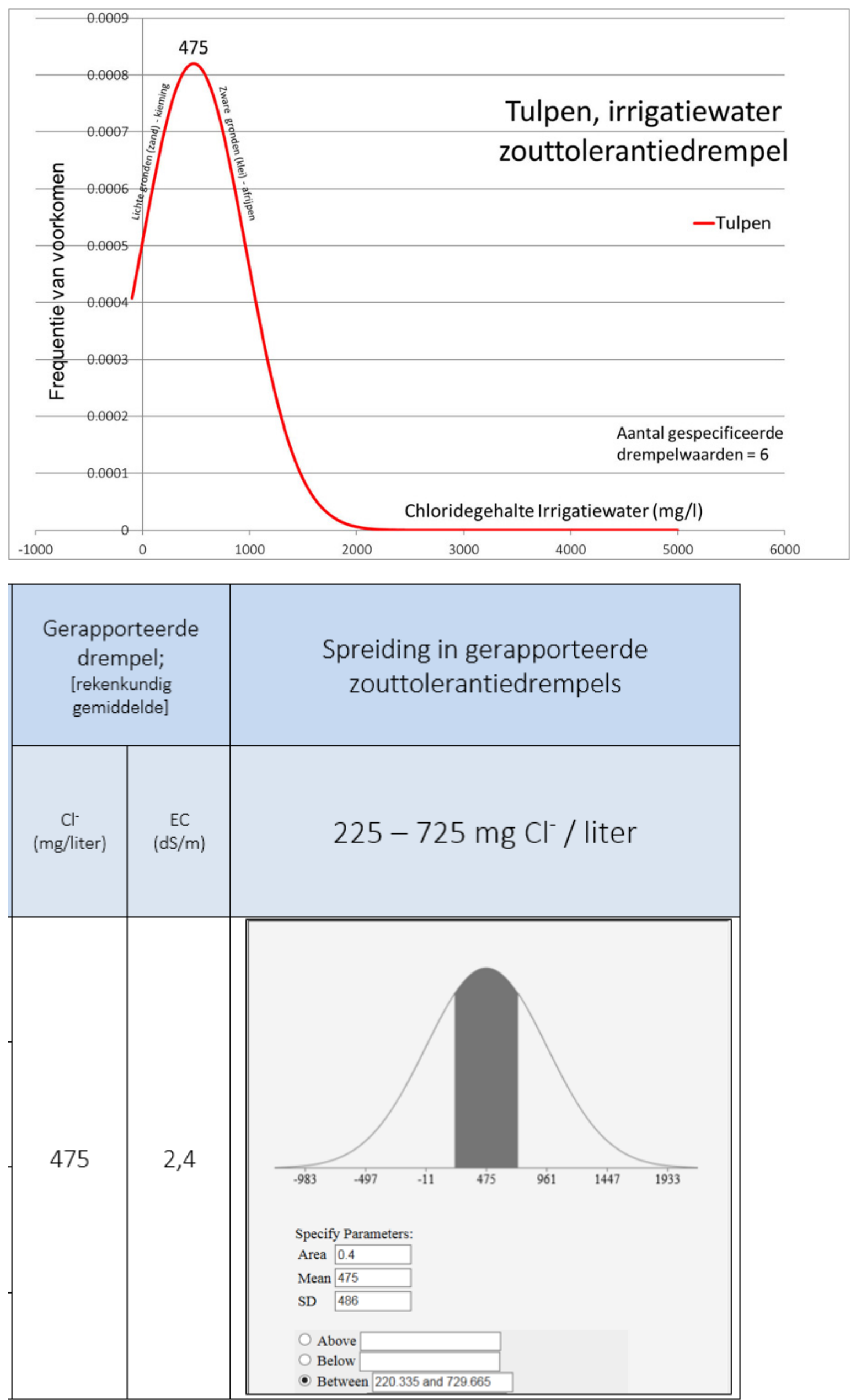


\subsection{Fruitbomen}

\section{A. Literatuur}

In 1951 vermeldt Rowaan in een overzicht van het inundatieonderzoek in Nederland tot 1944 in een Verslag van Landbouwkundig Onderzoek 57.3 een tolerantie waarde van $1000 \mathrm{mg} / \mathrm{l}$.

Onderzoek van J. Riemens met sproeiwater bij fruitteelt met $1000 \mathrm{mg} / \mathrm{l} \mathrm{Cl}$ in de IJsselmeerpolders (1941) is aangehaald door C. van den Berg (1952).

In 1983 wordt in de ICW Nota 1461 (P.C. Jansen) $300 \mathrm{mg} / \mathrm{l}$ genoemd als drempelwaarde van het chloridegehalte van beregeningswater voor de fruitteelt.

Uit het literatuuronderzoek "Actualisering Zouttolerantie", uitgevoerd door Roest et al. (2003) worden voor fruitteelt binnen de Agricom-gewasgroep voor fruitbomen waarden van $171 \mathrm{mg} / \mathrm{l}$ vermeld. Ten behoeve van de ontwikkeling en het gebruik van het RIZA-instrumentarium werd in dit project een waarde voor het $10 \%$ gevoeligste gewas afgeleid, van $150 \mathrm{mg} / \mathrm{l} \mathrm{Cl}$ voor deze categorie.

In Eurofins (2015c) wordt voor de waterkwaliteit voor fruitteelt een drempelwaarde van $60 \mathrm{mg} / \mathrm{l} \mathrm{Cl}$ aangehouden. De bron(nen) van de in dit informatieblad gespecificeerde grenswaarde( $n$ ) konden ondanks gerichte navraag - niet worden achterhaald.

\section{Referenties}

Berg, C. van den, 1952. De invloed van opgenomen zouten op de groei en productie van landbouwgewassen op zoute gronden. De inundaties gedurende 1944-1945 en hun gevolgen voor de landbouw Deel XII. In: Verslagen van Landbouwkundige Onderzoekingen 58.5 Also: Doctoral thesis Landbouwhogeschool, Wageningen. Staatsdrukkerij Uitgeversbedrijf, 's-Gravenhage, 118 pp. See http://edepot.wur.nl/176815

Eurofins, 2015c. Waterkwaliteit in de fruitteelt. Bijlage/Toelichting. Eurofins Agro Laboratories, Wageningen.

Jansen, P.C., 1983. Waterkwaliteit. Een beknopt overzicht van begrippen, parameters, typering en normen. Instituut voor Cultuurtechniek en Waterhuishouding, ICW-Nota 1461, Wageningen. pp. 26-28.

Roest, C.W.J., P.J.T. van Bakel \&, A.A.M.F.R. Smit, 2003. Actualisering van de zouttolerantie van landen tuinbouwgewassen ten behoeve van de berekening van de zoutschade in Nederland met het RIZA-instrumentarium. Memo Alterra, Wageningen, $16 \mathrm{p}$.

Rowaan, P.A., 1951. Overzicht van inundatie-onderzoek in Nederland tot 1944. De inundaties gedurende 1944-1945 en hun gevolgen voor de landbouw Deel III. Verslagen van Landbouwkundige Onderzoekingen 57.3, 36 pp. 


\section{B. Gegevens}
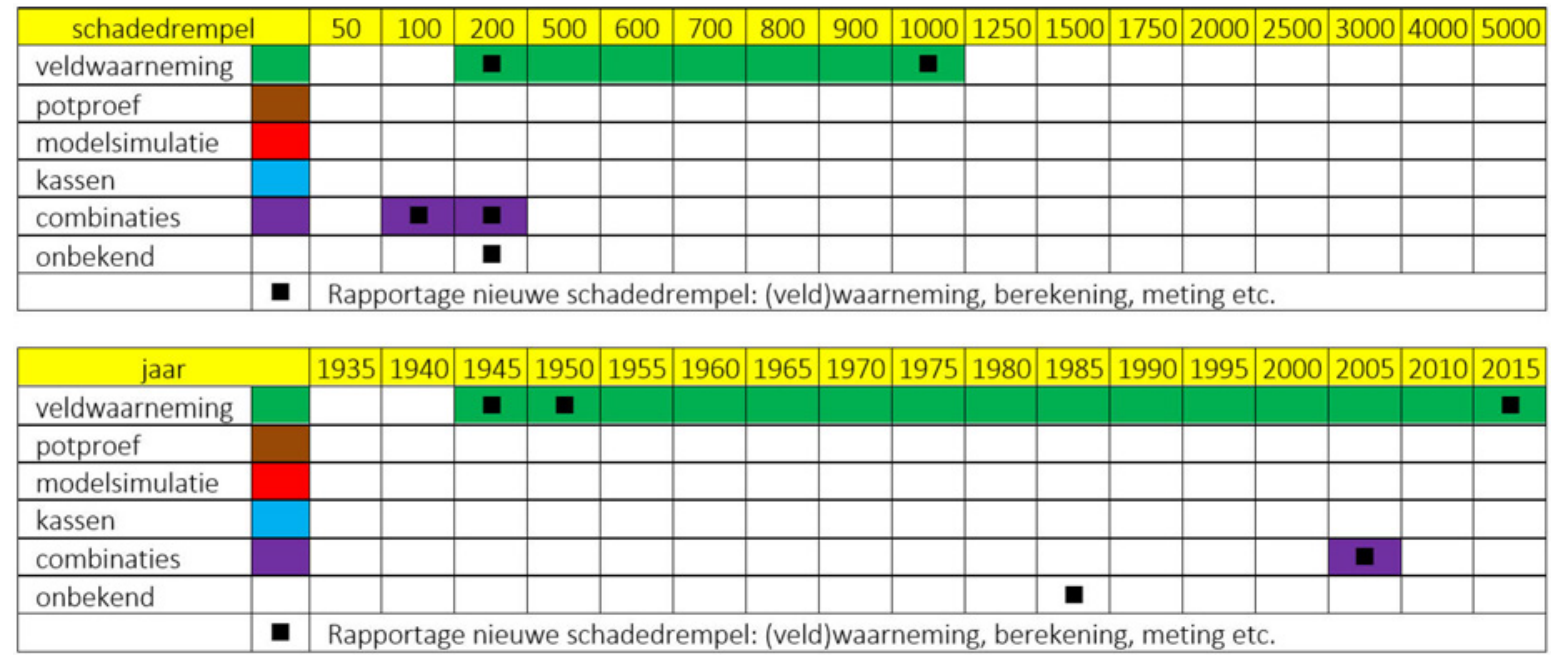

\begin{tabular}{|c|c|c|c|c|c|c|c|c|c|c|c|c|c|c|c|}
\hline No & Gewas(groep) & 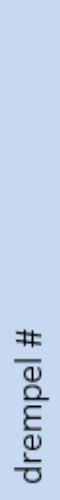 & $\begin{array}{l}\frac{1}{\pi} \\
. \mathbb{0} \\
.\end{array}$ & 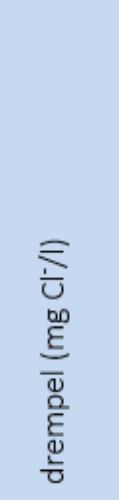 & 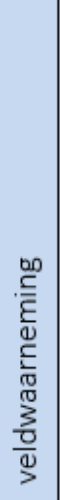 & 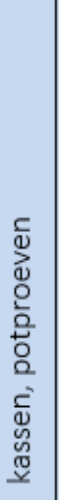 & 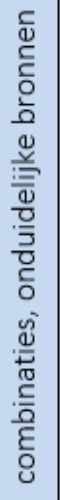 & 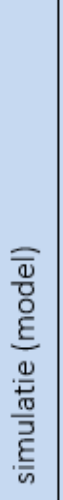 & 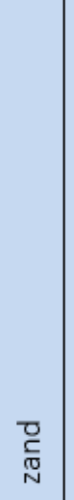 & 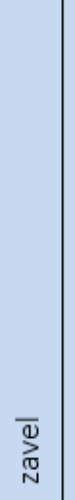 & $\frac{\bar{\alpha}}{\underline{y}}$ & 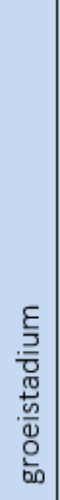 & 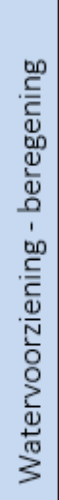 & 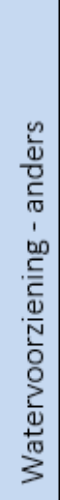 & 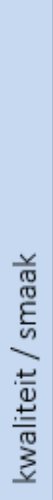 \\
\hline \multirow{6}{*}{28} & \multirow{6}{*}{ Fruitbomen } & 1 & 1946 & 1000 & $x$ & & & & & & & & & & \\
\hline & & 2 & 1952 & 1000 & $x$ & & & & & & & & & & \\
\hline & & 3 & 1983 & 300 & $x$ & & & & & & & & & & \\
\hline & & 4 & 2003 & 171 & & & $x$ & & & & & & $x$ & & \\
\hline & & 5 & 2003 & 171 & & & $x$ & & & & & & $x$ & & \\
\hline & & 6 & 2003 & 150 & & & $\times$ & & & & & & $x$ & & \\
\hline
\end{tabular}


C. Interpretatie

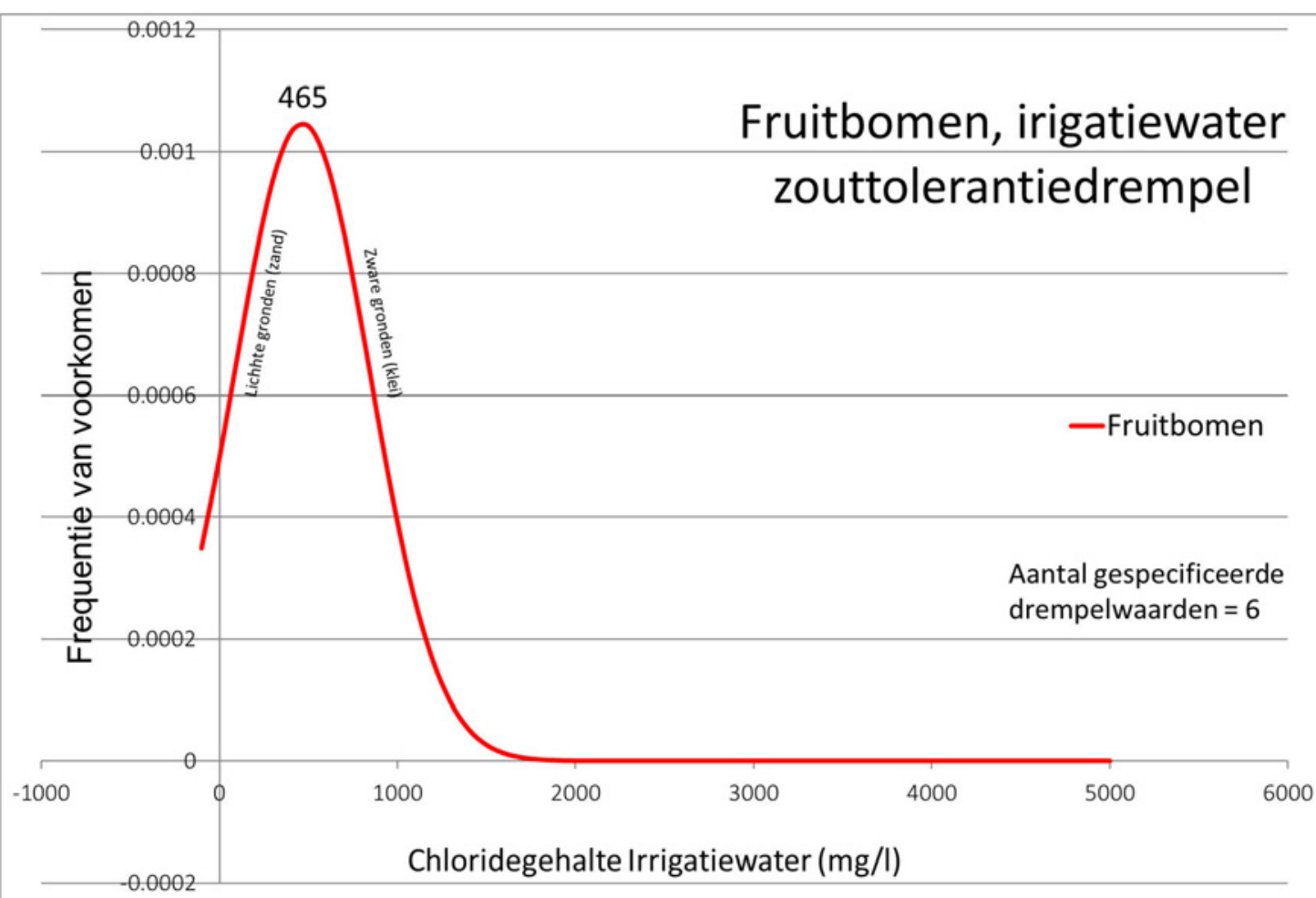

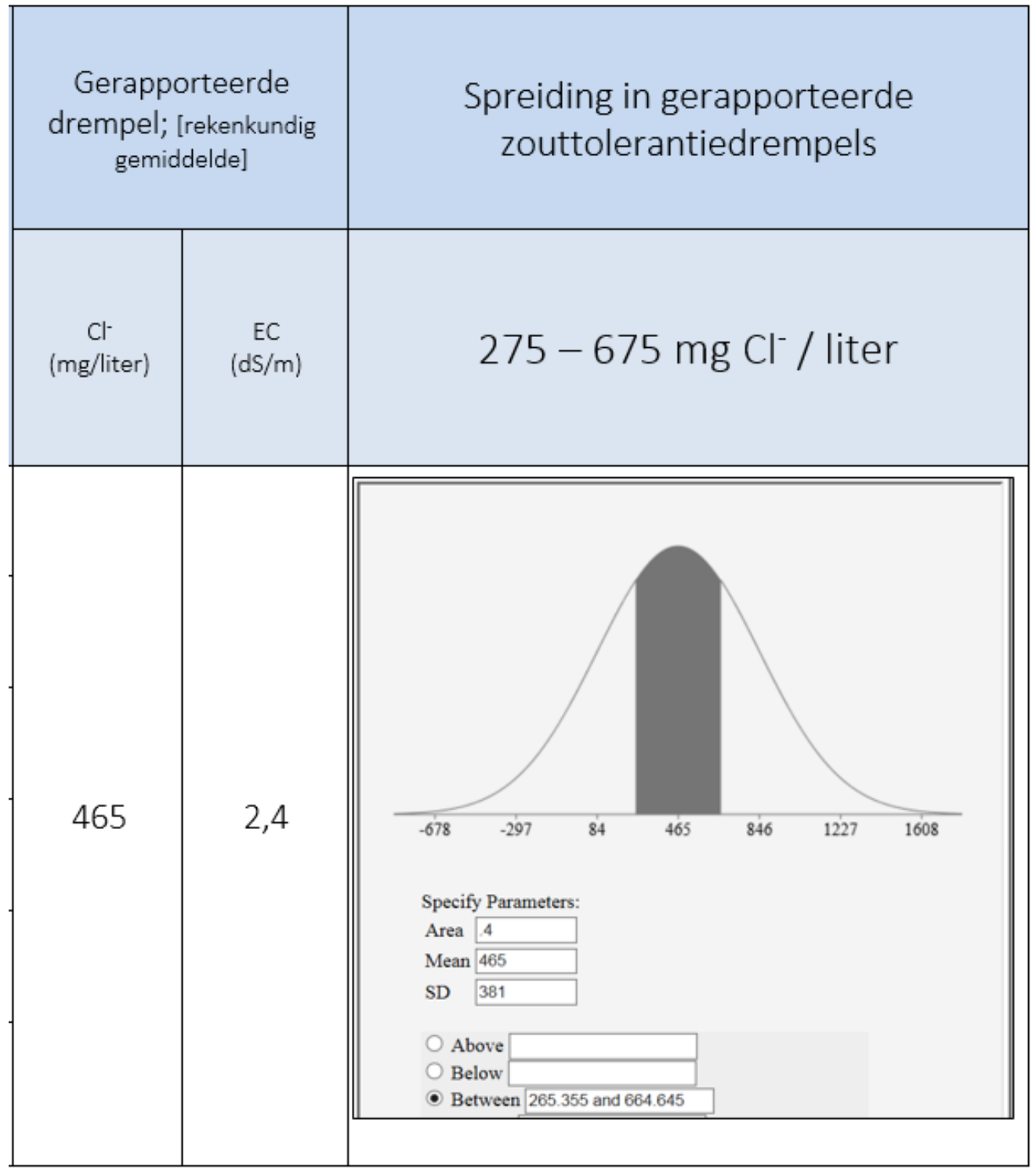




\subsection{Paprika, tomaat, komkommer, sla}

\section{A. Literatuur}

Onderzoek van Riemens (1941) toonde aan dat het maximaal toelaatbaar zoutgehalte van polderwater in kassen 500 mg/l Cl mag bedragen (Van den Berg, 1952).

In 1983 wordt in ICW Nota 1461 (P.C. Jansen) 200 mg/l vermeld voor het toelaatbare chloridegehalte van beregeningswater. Uit het literatuuronderzoek "Actualisering Zouttolerantie", in 2003 uitgevoerd door Roest et al. ten behoeve van de ontwikkeling en het gebruik van het RIZA-instrumentarium is voor deze categorie een waarde voor het $10 \%$ gevoeligste gewas afgeleid, te weten $142 \mathrm{mg} / \mathrm{l} \mathrm{Cl}$.

In het literatuuronderzoek 'Actualisering Zouttolerantie' dat werd uitgevoerd door Roest et al. (2003) ten behoeve van de ontwikkeling en het gebruik van het RIZA-instrumentarium zijn, mede met behulp van 'expert judgement' drempelwaarden voor $0 \%$ schade bij deze kasgroenten vastgesteld, variërend van 142 tot $356 \mathrm{mg} \mathrm{Cl} / \mathrm{l}$.

Eurofins (2015a) geeft voor sla (akkerbouw) een zouttolerantiedrempel van $300 \mathrm{mg} \mathrm{Cl} / \mathrm{l}$. De bron(nen) van de in dit informatieblad gespecificeerde grenswaarde(n) konden - ondanks gerichte navraag - niet worden achterhaald.

\section{Referenties}

Berg, C. van den, 1952. De invloed van opgenomen zouten op de groei en productie van landbouwgewassen op zoute gronden. De inundaties gedurende 1944-1945 en hun gevolgen voor de landbouw Deel XII. In: Verslagen van Landbouwkundige Onderzoekingen 58.5 Also: Doctoral thesis Landbouwhogeschool, Wageningen. Staatsdrukkerij Uitgeversbedrijf, 's-Gravenhage, 118 pp. See http://edepot.wur.nl/176815

Eurofins, 2015a. Waterkwaliteit in de glastuinbouw. Bijlage/Toelichting. Eurofins Agro Laboratories, Wageningen.

Jansen, P.C., 1983. Waterkwaliteit. Een beknopt overzicht van begrippen, parameters, typering en normen. Instituut voor Cultuurtechniek en Waterhuishouding, ICW-Nota 1461, Wageningen. pp. 26-28.

Roest, C.W.J., P.J.T. van Bakel \&, A.A.M.F.R. Smit, 2003. Actualisering van de zouttolerantie van landen tuinbouwgewassen ten behoeve van de berekening van de zoutschade in Nederland met het RIZA-instrumentarium. Memo Alterra, Wageningen, 16 p. 


\section{B. Gegevens}

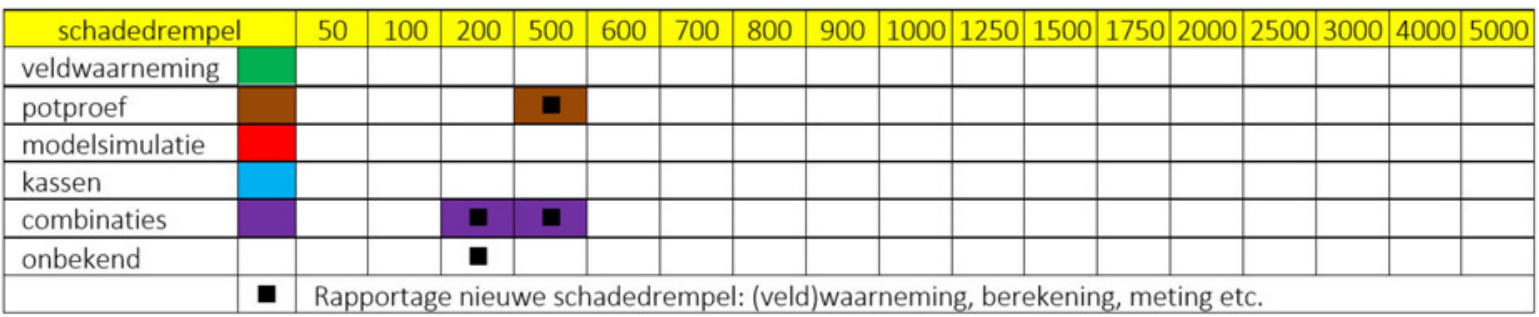

\begin{tabular}{|c|c|c|c|c|c|c|c|c|c|c|c|c|c|c|c|c|c|c|}
\hline jaar & & 1935 & 1940 & 1945 & 1950 & 1955 & 1960 & 1965 & 1970 & 1975 & 1980 & 1985 & 1990 & 1995 & 2000 & 2005 & 2010 & 2015 \\
\hline \multicolumn{19}{|c|}{ 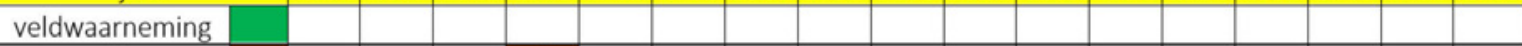 } \\
\hline \multicolumn{19}{|l|}{ potproef } \\
\hline \multicolumn{19}{|l|}{ kassen } \\
\hline \multicolumn{19}{|l|}{ combinaties } \\
\hline onbekend & & & & & & & & & & & & $\mathbf{a}$ & & & & & & \\
\hline
\end{tabular}

\begin{tabular}{|c|c|c|c|c|c|c|c|c|c|c|c|c|c|c|c|}
\hline No & Gewas(groep) & 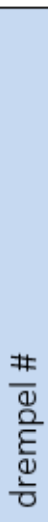 & $\begin{array}{l}\stackrel{i}{\pi} \\
\stackrel{\pi}{\pi}\end{array}$ & 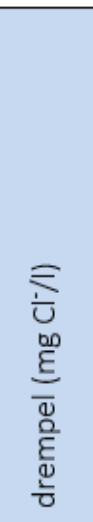 & 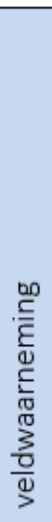 & 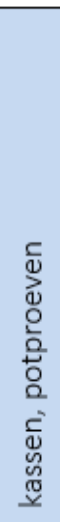 & 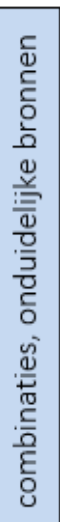 & 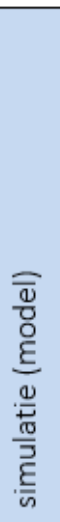 & $\begin{array}{l}\text { D } \\
\text { CE } \\
\text { N }\end{array}$ & 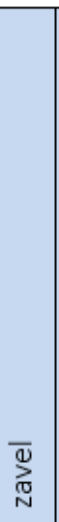 & $\frac{\bar{\omega}}{\underline{x}}$ & 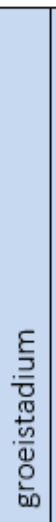 & 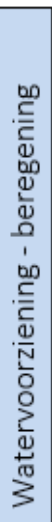 & 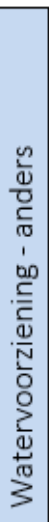 & 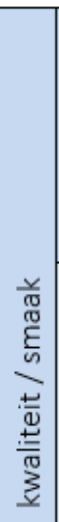 \\
\hline \multirow{6}{*}{29} & \multirow{6}{*}{$\begin{array}{c}\text { Paprika, } \\
\text { tomaat, } \\
\text { komkommer, } \\
\text { sla }\end{array}$} & 1 & 1946 & 500 & & $\times$ & & & & & & & & & \\
\hline & & 2 & 1952 & 500 & & $x$ & & & & & & & & & \\
\hline & & 3 & 1983 & 200 & & $\times$ & & & & & & & & & \\
\hline & & 4 & 2003 & 356 & & & $\times$ & & & & & & $x$ & & \\
\hline & & 5 & 2003 & 142 & & & $x$ & & & & & & $x$ & & \\
\hline & & 6 & 2003 & 150 & & & $x$ & & & & & & $x$ & & \\
\hline
\end{tabular}


C. Interpretatie
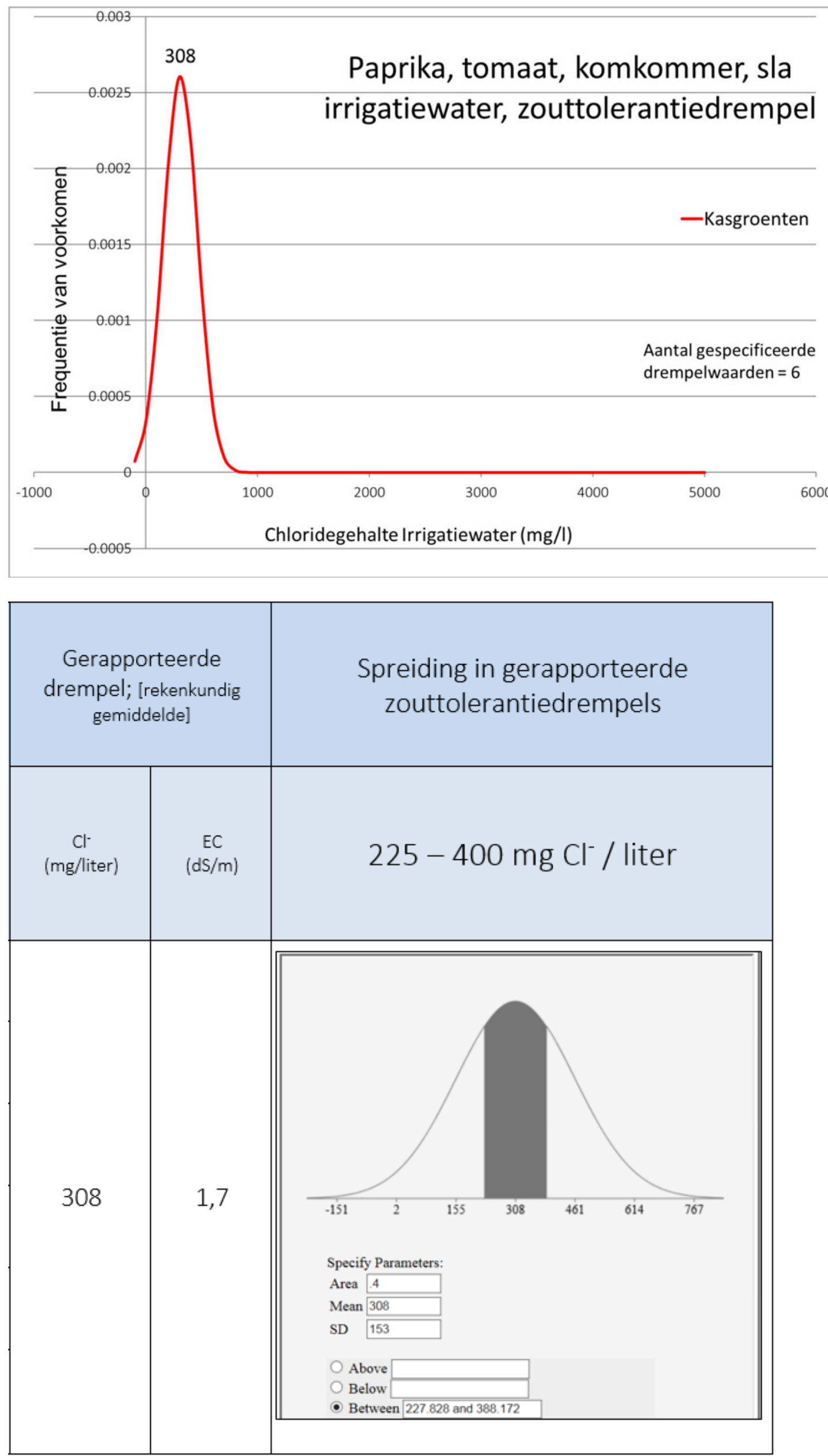


\subsection{Komkommer}

\section{A. Literatuur}

Van den Berg (1967) refereert aan de proeven van Bierhuizen: komkommers zijn zeer gevoelig; de drempelwaarde voor gietwater bedraagt 50 à $75 \mathrm{mg} / \mathrm{l} \mathrm{Cl}$.

In het Jaarverslag van het Instituut voor Cultuurtechniek en Waterhuishouding (ICW) van 1968 wordt een waarde van $200 \mathrm{mg} / \mathrm{l}$ vermeld.

In 1983 wordt in ICW Nota 1461 (P.C. Jansen) 200 mg/l vermeld voor het toelaatbare chloride gehalte in het beregeningswater.

Eurofins (2015d) geeft geen specifieke richtlijnen m.b.t. zouttolerantiedrempels voor komkommer.

Berg, C. van den, 1967. Tuinbouw en waterverontreiniging. Instituut voor Cultuurtechniek en waterhuishouding, Verspreide overdrukken 55, Med. Dir. Tuinb. p $113-122$.

Eurofins, 2015d. Waterkwaliteit in de glastuinbouw. Bijlage/Toelichting. Eurofins Agro Laboratories, Wageningen.

ICW, 1968. Jaarverslag van het Instituut voor Cultuurtechniek en Waterhuishouding (ICW) van het instituut voor cultuurtechniek en waterhuishouding, Wageningen.

\section{Referenties}

Jansen, P.C., 1983. Waterkwaliteit. Een beknopt overzicht van begrippen, parameters, typering en normen. Instituut voor Cultuurtechniek en Waterhuishouding, ICW-Nota 1461, Wageningen. pp. 26-28. 


\section{B. Gegevens}

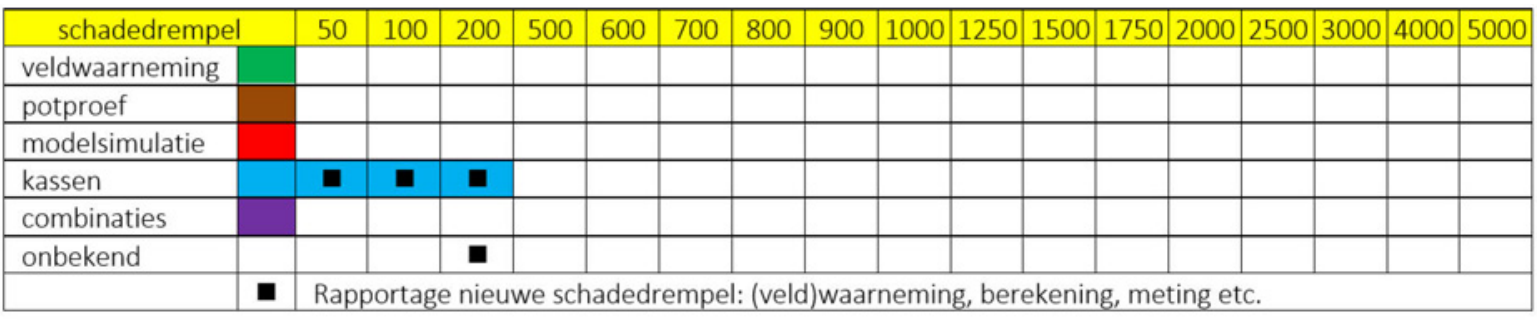

\begin{tabular}{|c|c|c|c|c|c|c|c|c|c|c|c|c|c|c|c|c|c|c|}
\hline jaat & & 1935 & 1940 & 1945 & 1950 & 1955 & 1960 & 1965 & 1970 & 1975 & 1980 & 1985 & 1990 & 1995 & 2000 & 2005 & 2010 & 2015 \\
\hline \multicolumn{19}{|c|}{ (2) } \\
\hline \multicolumn{19}{|c|}{ potproef } \\
\hline \multicolumn{19}{|c|}{ modelsimulatie } \\
\hline kassen & & & & & & & & $\square$ & $\square$ & $\square$ & & & & & & & & \\
\hline \multicolumn{19}{|l|}{ combinaties } \\
\hline onbekend & & & & & & & & & & & & $\mathbf{a}$ & & & & & & \\
\hline
\end{tabular}

\begin{tabular}{|c|c|c|c|c|c|c|c|c|c|c|c|c|c|c|c|}
\hline No & Gewas(groep) & 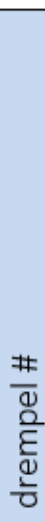 & $\begin{array}{l}\frac{1}{\pi} \\
. \mathbb{0}\end{array}$ & 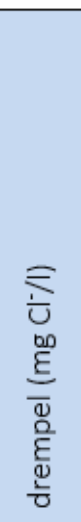 & 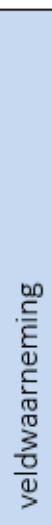 & 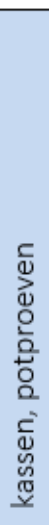 & 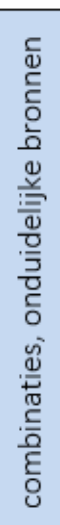 & 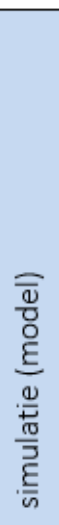 & 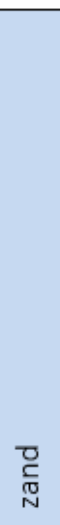 & 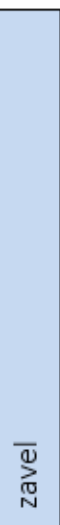 & $\frac{\bar{\omega}}{\underline{y}}$ & 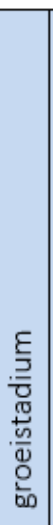 & 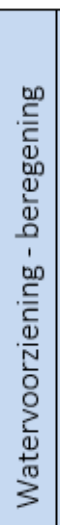 & 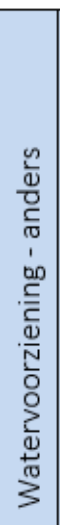 & 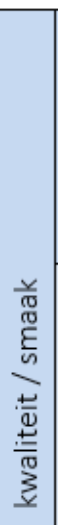 \\
\hline \multirow{5}{*}{30} & \multirow{5}{*}{ Komkommer } & 1 & 1966 & 75 & & $x$ & & & $x$ & & $x$ & & $x$ & & \\
\hline & & 2 & 1967 & 50 & & $x$ & & & $\times$ & & $x$ & & & & \\
\hline & & 3 & 1968 & 200 & & $x$ & & & $\times$ & & $x$ & & & & \\
\hline & & 4 & 1972 & 40 & & $x$ & $x$ & & & & & & & & \\
\hline & & 5 & 1983 & 200 & & $x$ & & & & & & & & & \\
\hline
\end{tabular}


C. Interpretatie
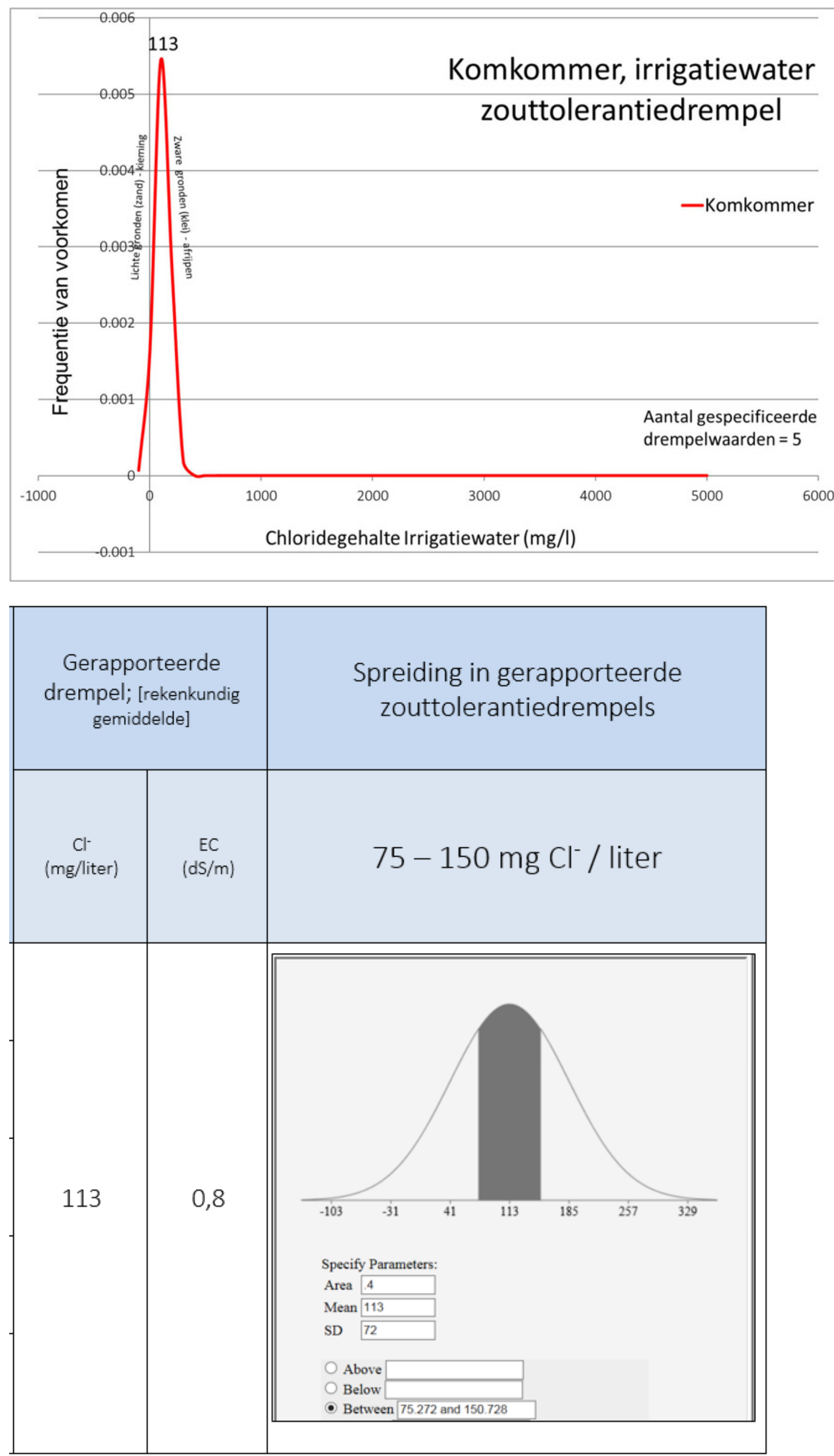


\subsection{Paprika}

\section{A. Literatuur}

In 1983 wordt in ICW Nota 1461 (P.C. Jansen) voor het toelaatbare chloridegehalte van gietwater voor paprika in de glastuinbouw $200 \mathrm{mg} / \mathrm{l}$ vermeld. Voor substraatteelt worden hogere eisen gesteld: $50 \mathrm{mg} / \mathrm{l} \mathrm{Cl}$.

Eurofins (2015d) geeft geen specifieke richtlijnen m.b.t. zouttolerantiedrempels voor paprika.

\section{Referenties}

Eurofins, 2015d. Waterkwaliteit in de glastuinbouw. Bijlage/Toelichting. Eurofins Agro Laboratories, Wageningen.

Jansen, P.C., 1983. Waterkwaliteit. Een beknopt overzicht van begrippen, parameters, typering en normen. Instituut voor Cultuurtechniek en Waterhuishouding, ICW-Nota 1461, Wageningen. pp. 26-28. 
C. Interpretatie
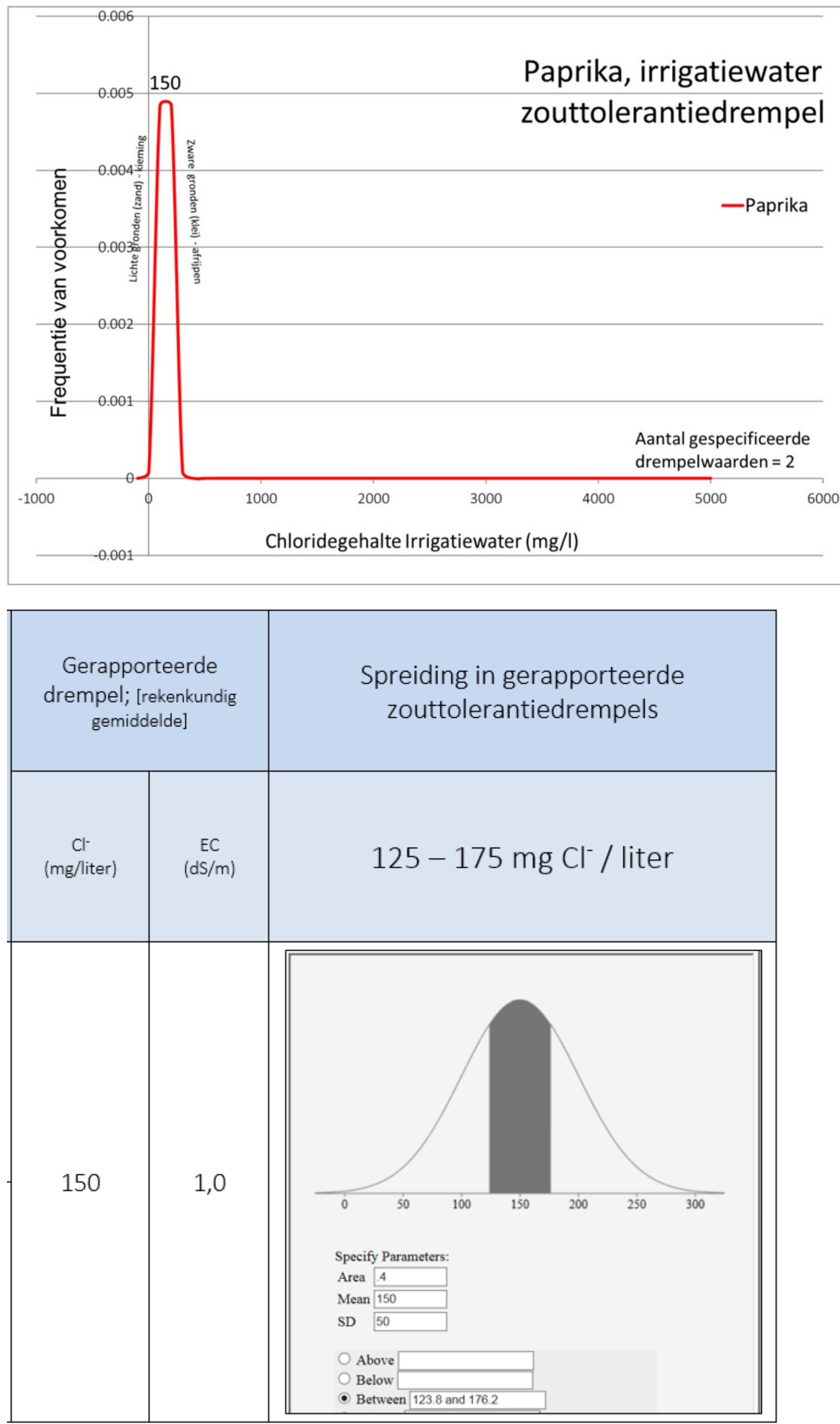


\subsection{Kropsla, IJsbergsla}

\section{A. Literatuur}

Shannon \& Grieve (1999) noemen voor krop-, en ijsbergsla waarden van $225 \mathrm{mg} / \mathrm{l} \mathrm{Cl}$ als zouttolerantiedrempel van beregeningswater.

In Alterra rapport 2201 uit 2011 (Bakel en Stuyt) wordt een drempelwaarde van 375 mg/l Cl genoemd.

\section{Referenties}

Bakel, P.J.T. van en L.C.P.M. Stuyt, 2011. Actualisering van de kennis van de zouttolerantie van landbouwgewassen, op basis van literatuuronderzoek, expertkennis en praktische ervaringen. Wageningen, Alterra-rapport 2201.

Shannon, M.C. \& C.M. Grieve, 1999. Tolerance of vegetable crops to salinity. Scientia Horticulturae 78: 5-38. 


\section{B. Gegevens}

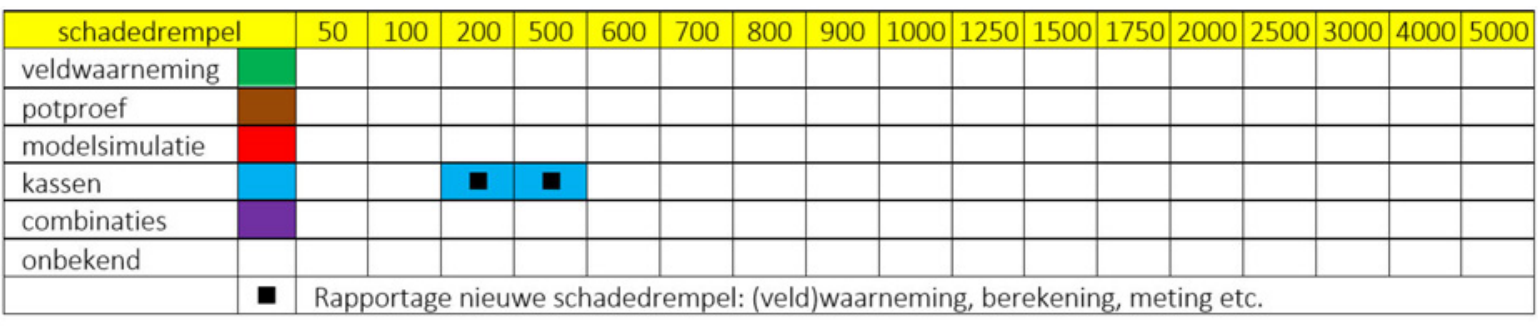

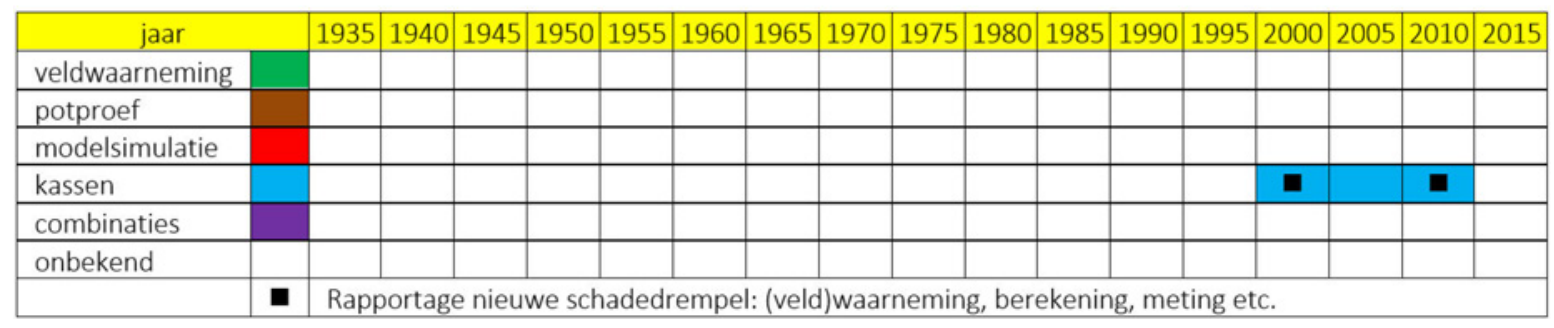

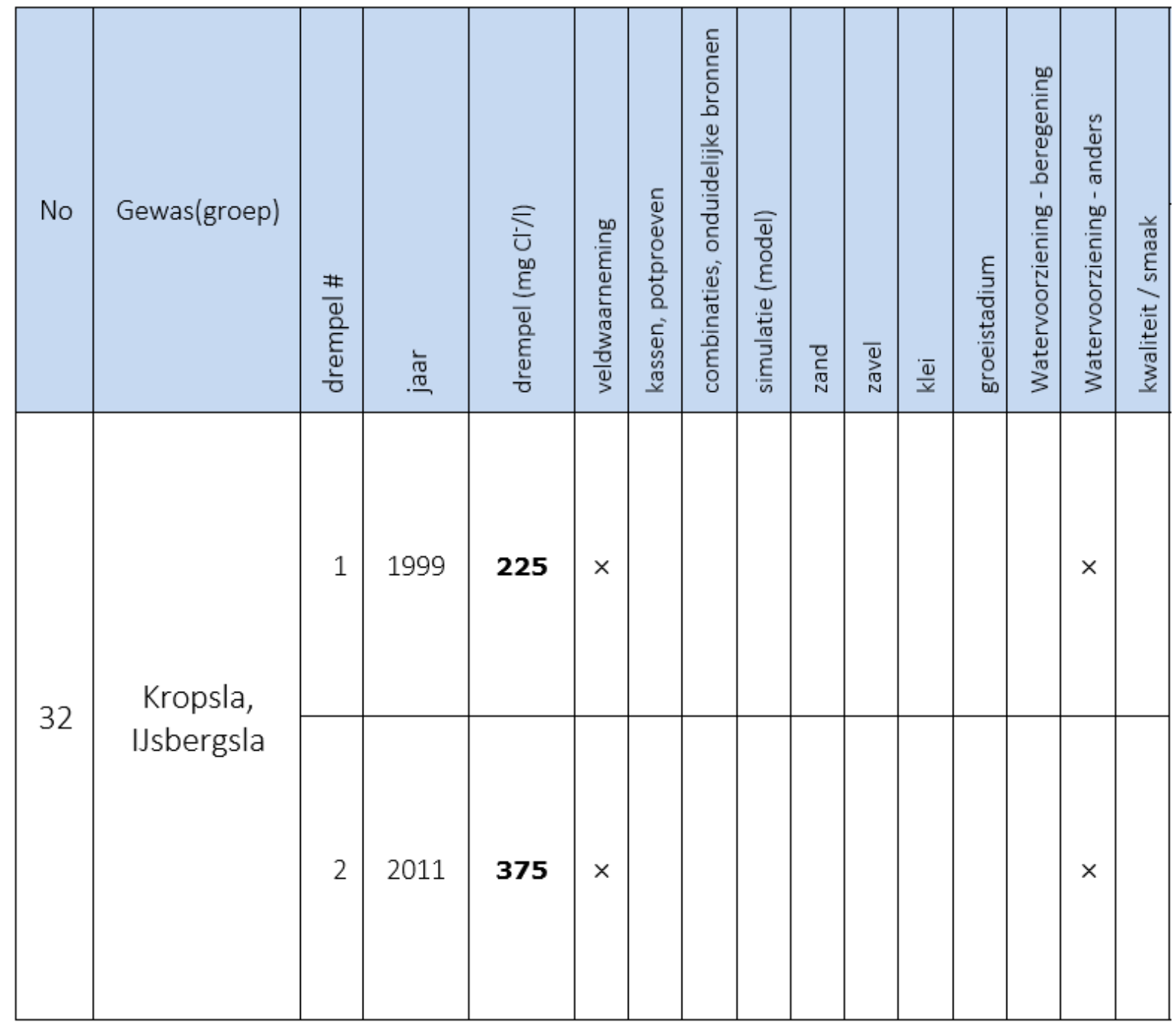


C. Interpretatie

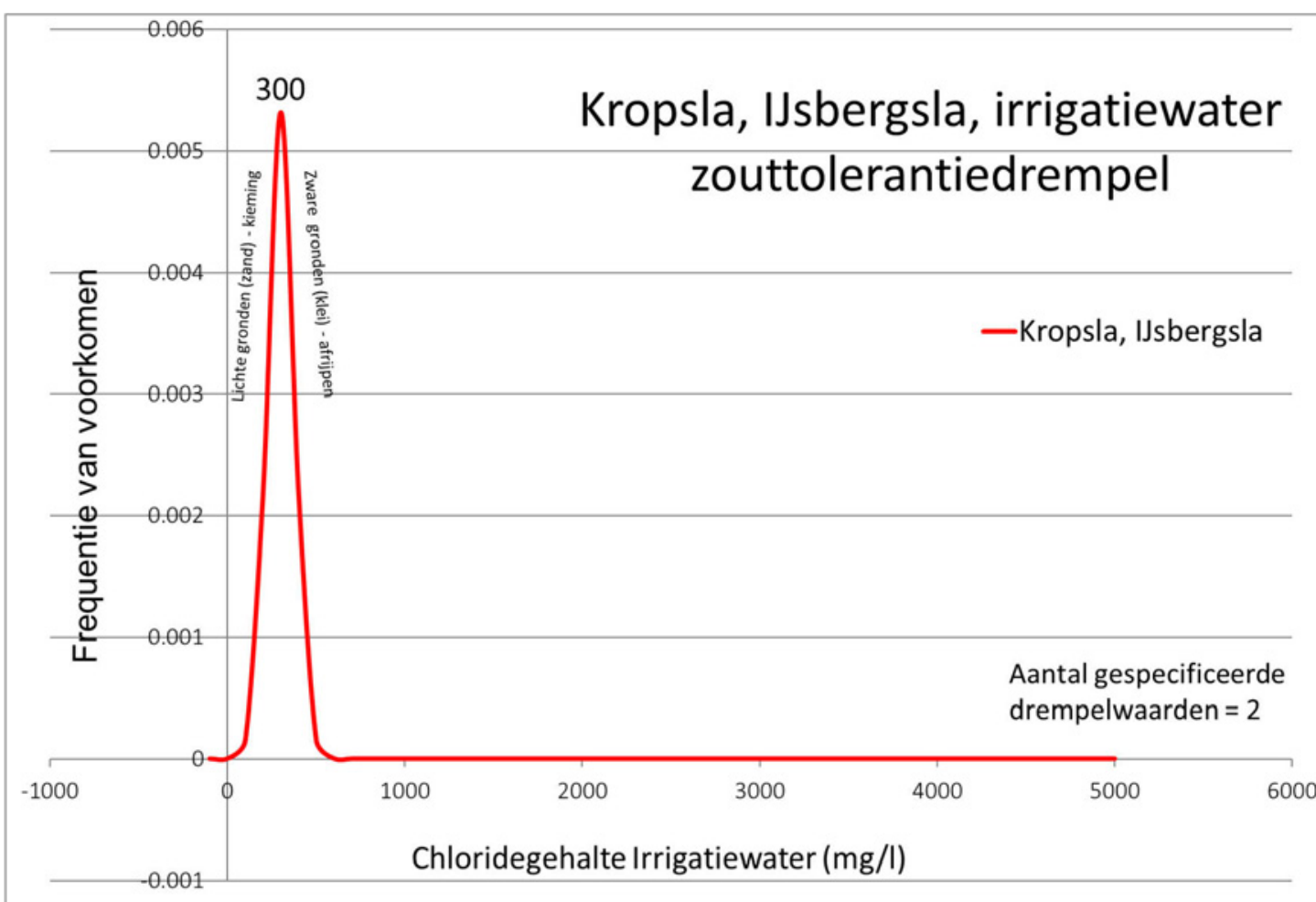

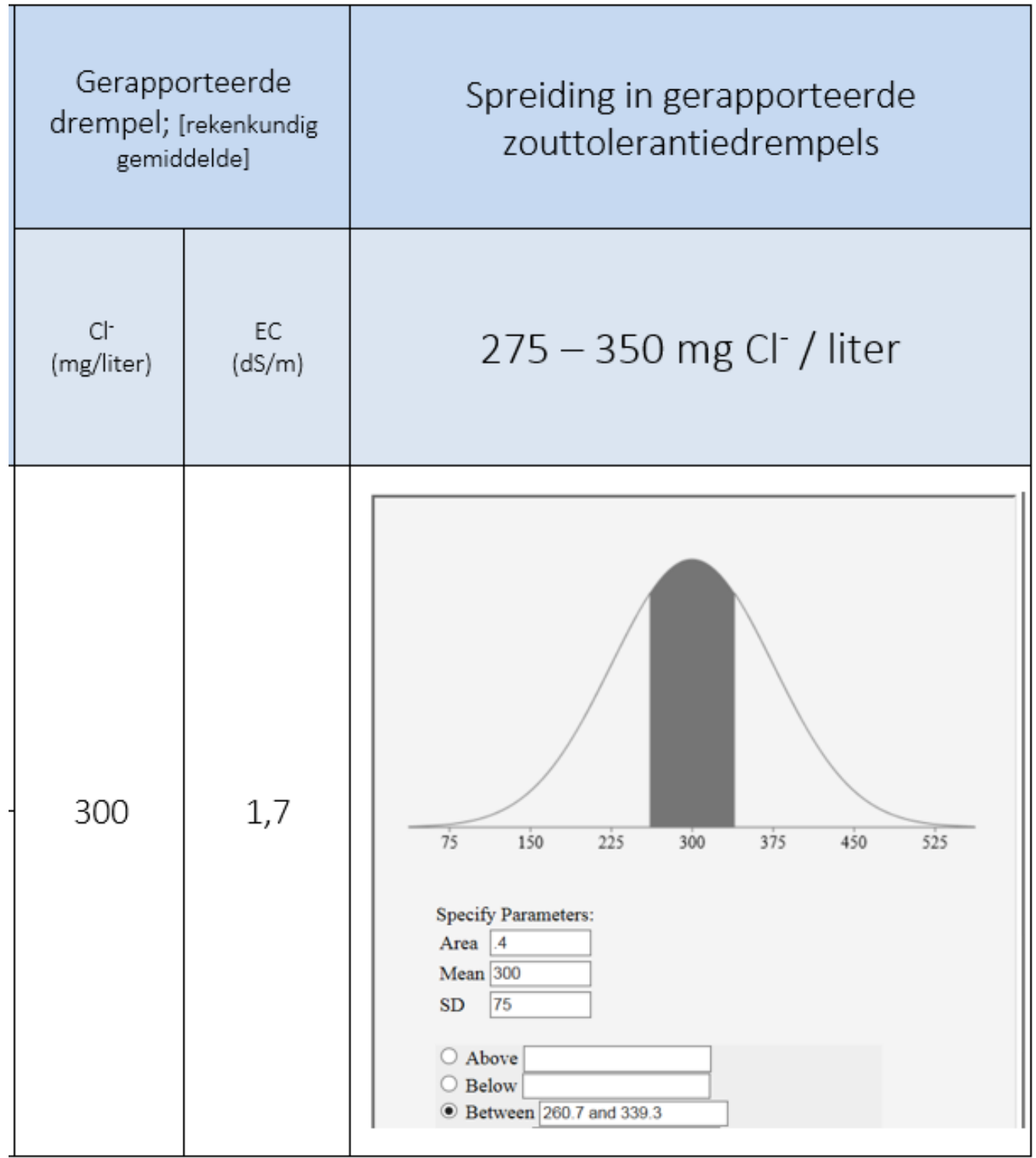




\subsection{Sla}

\section{A. Literatuur}

Van der Valk (ICW 1962) verrichtte onderzoek d.m.v. veldproeven met zout irrigatiewater aan sla, bonen en bloemkool. Doseringen tot $2500 \mathrm{mg} \mathrm{Cl}$ per liter in het beregeningswater bleken in het natte jaar 1962 geen nadelige invloed op de opbrengst te hebben. Wel trad er bij hoge dosering ernstig structuurverval op.

In Alterra rapport 2201 "Actualisering Zouttolerantie" (Bakel en Stuyt, 2011) is de tabel "Risico op zoutschade aan landbouwgewassen bij verschillende zoutgehalten van beregeningswater" beschikbaar gesteld door DLV Plant, die gebruikt wordt voor advisering. Ook is in dit rapport een tabel met zouttolerantiewaarden opgenomen uit het PAGV-handboek (Proefstation voor de akkerbouw en de groetenteelt in de volle grond).

$\begin{array}{lll}\text { Bij lage tolerantie: } & \text { Bron: DLV, } & 340 \mathrm{mg} \mathrm{CL} / \mathrm{I} \\ \text { Bij hoge tolerantie: } & \text { Bron: DLV, } & 500 \mathrm{mg} \mathrm{CL/I} \\ \text { Bij lage tolerantie: } & \text { Bron: PAGV, } & 300 \mathrm{mg} \mathrm{CL/I} \\ \text { Bij hoge tolerantie: } & \text { Bron: PAGV, } & 600 \mathrm{mg} \mathrm{CL/I}\end{array}$

Eurofins (2015a) geeft voor sla (akkerbouw) een zouttolerantiedrempel van $300 \mathrm{mg} \mathrm{Cl} / \mathrm{l}$. De bron(nen) van de in dit informatieblad gespecificeerde grenswaarde( $n)$ konden - ondanks gerichte navraag - niet worden achterhaald.

\section{Referenties}

Bakel, P.J.T. van en L.C.P.M. Stuyt, 2011. Actualisering van de kennis van de zouttolerantie van landbouwgewassen, op basis van literatuuronderzoek, expertkennis en praktische ervaringen. Wageningen, Alterra-rapport 2201.

Eurofins, 2015a. Waterkwaliteit in de akkerbouw. Bijlage/Toelichting. Eurofins Agro Laboratories, Wageningen.

ICW, 1962. Jaarverslag van het Instituut voor Cultuurtechniek en Waterhuishouding (ICW) van het instituut voor cultuurtechniek en waterhuishouding. Mededeling ICW 48, Wageningen, p 11. 
C. Interpretatie

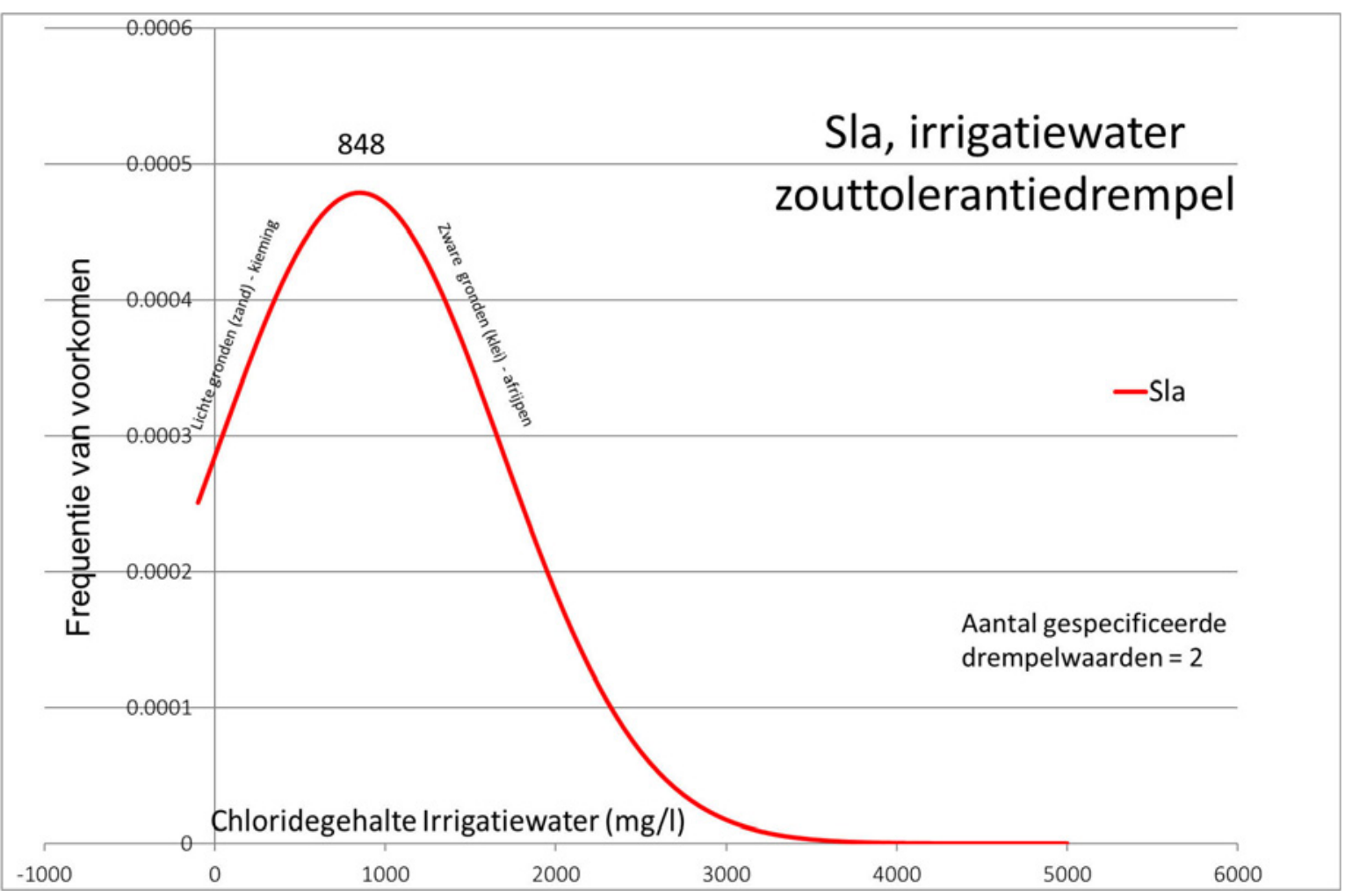

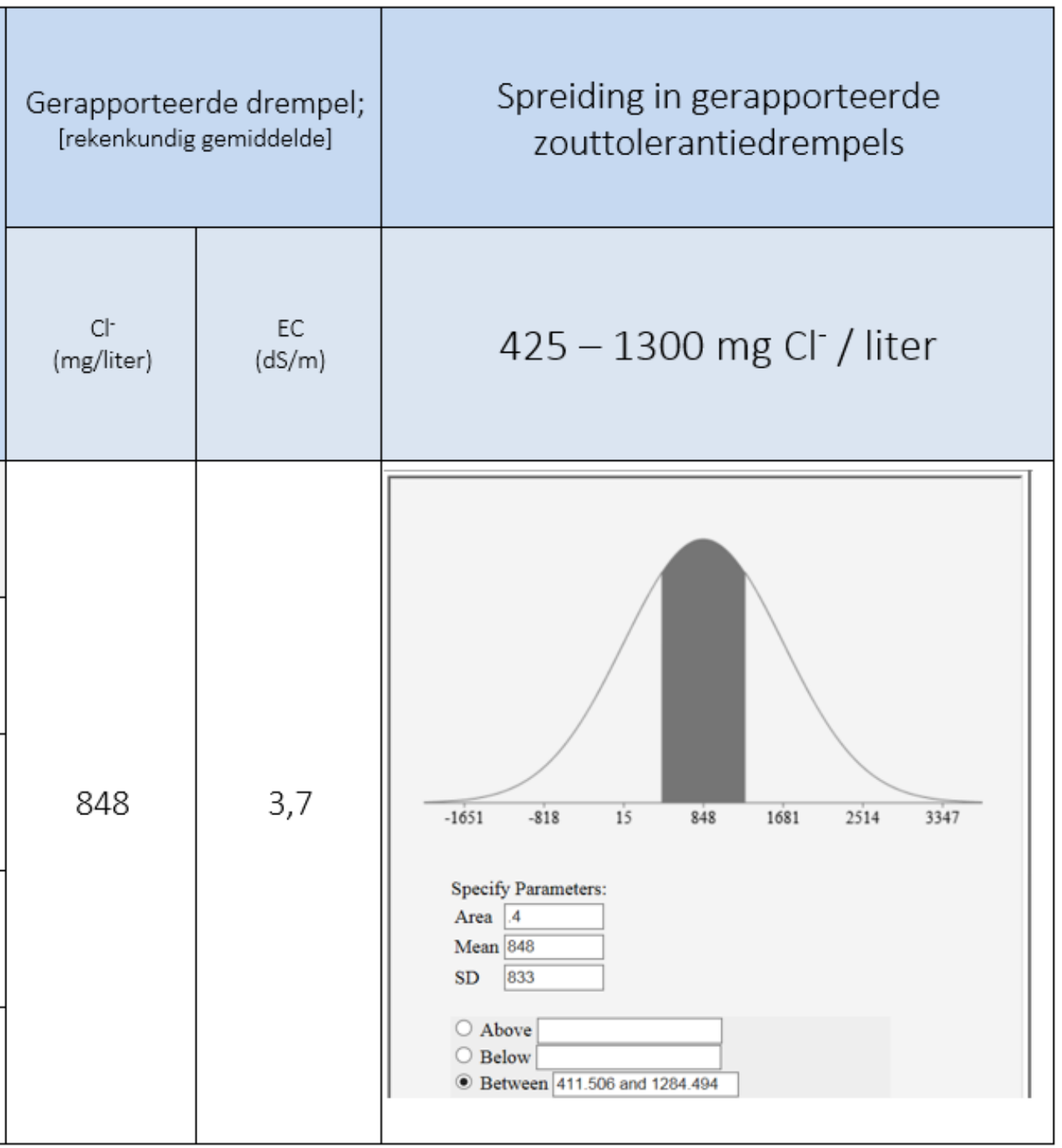




\subsection{Tomaten}

\section{A. Literatuur}

In het Jaarverslag van het Instituut voor Cultuurtechniek en Waterhuishouding (ICW) van 1966 werd voor tomaten een zouttolerantiegrens van $400 \mathrm{mg} / \mathrm{l} \mathrm{Cl}$ in beregeningswater vermeld.

In 1967 refereert van der Berg in een herdruk van proeven, uitgevoerd door Bierhuizen, op kleigrond, naar een tolerantiewaarde van $250 \mathrm{mg} / \mathrm{l} \mathrm{Cl}$ op kleigrond; minder streng dus dan op zandgrond waarvoor $100 \mathrm{mg} / \mathrm{l}$ vereist is.

In 2011 wordt in Alterra rapport 2201 voor tomaten een waarde van 200 mg/l aanbevolen.

\section{Referenties}

Bakel, P.J.T. van en L.C.P.M. Stuyt, 2011. Actualisering van de kennis van de zouttolerantie van landbouwgewassen, op basis van literatuuronderzoek, expertkennis en praktische ervaringen. Wageningen, Alterra-rapport 2201.

Berg, C. van den, 1967. Tuinbouw en waterverontreiniging. Instituut voor Cultuurtechniek en waterhuishouding, Verspreide overdrukken 55, Med. Dir. Tuinb. p $113-122$.

ICW, 1966. Jaarverslag van het Instituut voor Cultuurtechniek en Waterhuishouding (ICW) van het instituut voor cultuurtechniek en waterhuishouding, Wageningen. 


\section{B. Gegevens}

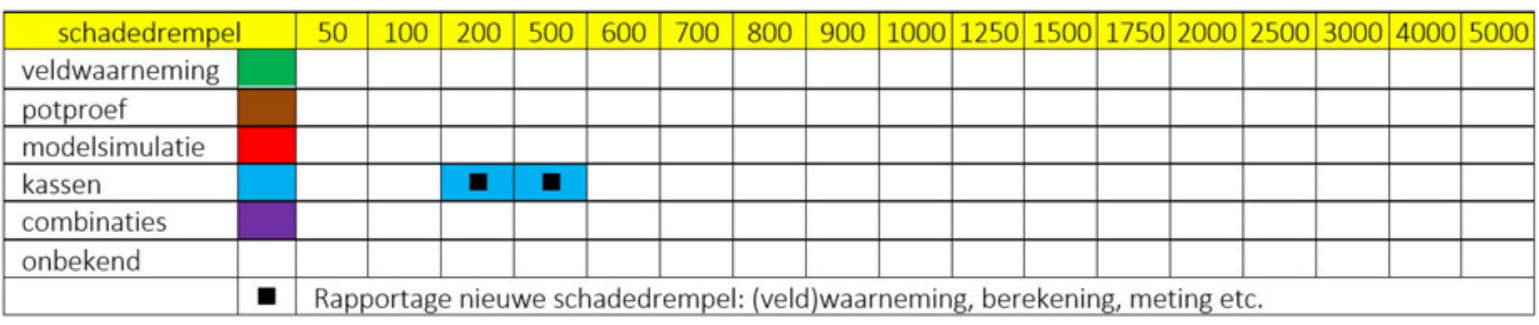

\begin{tabular}{|c|c|c|c|c|c|c|c|c|c|c|c|c|c|c|c|c|c|c|}
\hline jaar & & 1935 & 1940 & 1945 & 1950 & 1955 & 1960 & 1965 & 1970 & 1975 & 1980 & 1985 & 1990 & 1995 & 2000 & 2005 & 2010 & 2015 \\
\hline \multicolumn{19}{|c|}{ veldwaarneming } \\
\hline \multicolumn{19}{|c|}{ potproef } \\
\hline kassen & & ㅁ & & & & & & 口 & - & & & & & & & & & \\
\hline \multicolumn{19}{|l|}{ combinaties } \\
\hline
\end{tabular}

\begin{tabular}{|c|c|c|c|c|c|c|c|c|c|c|c|c|c|c|c|}
\hline No & Gewas(groep) & 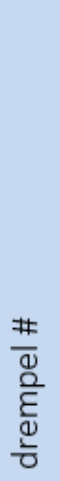 & $\begin{array}{l}\frac{1}{\pi} \\
. \\
.0\end{array}$ & 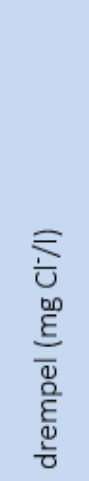 & 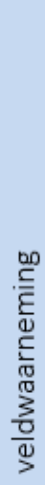 & 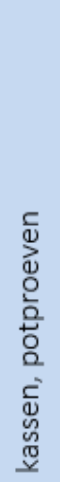 & 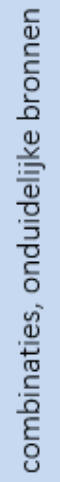 & 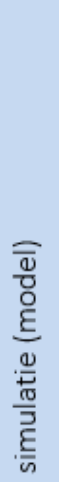 & 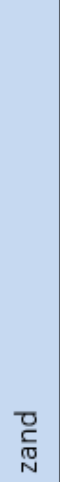 & 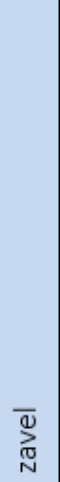 & $\frac{\bar{\omega}}{\underline{y}}$ & 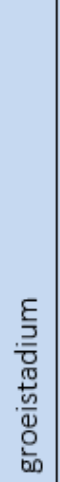 & 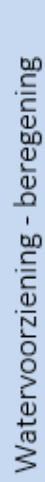 & 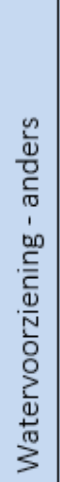 & 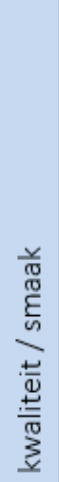 \\
\hline \multirow{4}{*}{34} & \multirow{4}{*}{ Tomaten } & 1 & 1934 & 500 & & $x$ & & & & & & & $x$ & & \\
\hline & & 2 & 1966 & 400 & & $x$ & & & $x$ & & $x$ & & $x$ & & \\
\hline & & 3 & 1967 & 250 & & $x$ & & & & & $x$ & & $x$ & & \\
\hline & & 4 & 1972 & 200 & & $x$ & & & & & & & $x$ & & \\
\hline
\end{tabular}


C. Interpretatie
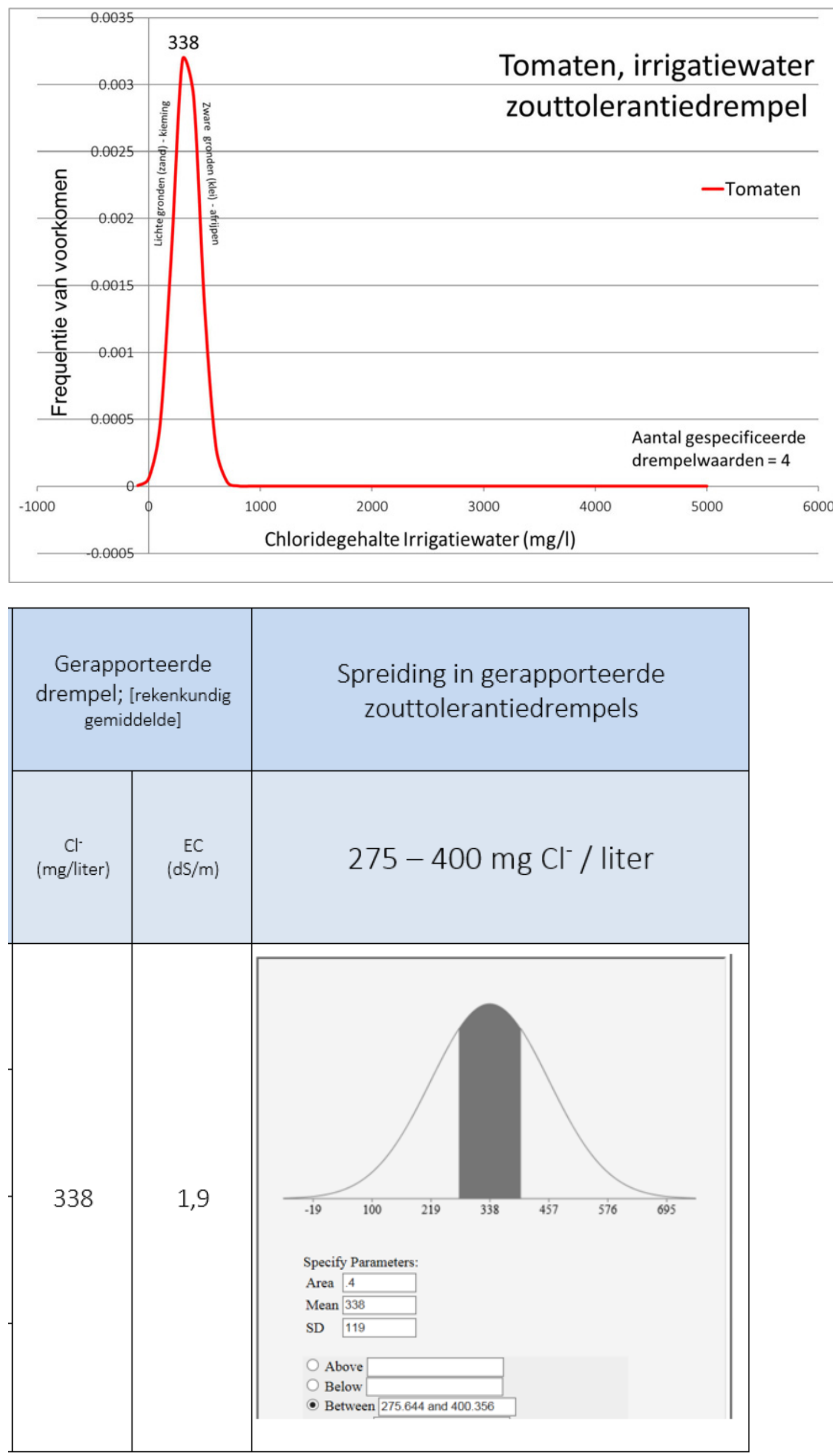


\subsection{Substraatteelt}

\section{A. Literatuur}

In 1983 specificeert P.C. Jansen in ICW Nota $146150 \mathrm{mg} / \mathrm{l}$ voor het toelaatbare chloridegehalte van water, bestemd voor substraatteelt.

In 1998 presenteert Huinink een herhaling van tabellen uit 1994, waarin voor substraat $25 \mathrm{mg} / \mathrm{Cl}$ wordt aanbevolen.

\section{Referenties}

Huinink, J.T.M., 1998. Het economisch belang van water in de landbouw. Rapport Informatie- en Kennis Centrum Landbouw (IKC-Landbouw), Ede, p 26-27.

Jansen, P.C., 1983. Waterkwaliteit. Een beknopt overzicht van begrippen, parameters, typering en normen. Instituut voor Cultuurtechniek en Waterhuishouding, ICW-Nota 1461, Wageningen. pp. 26-28. 


\section{B. Gegevens}

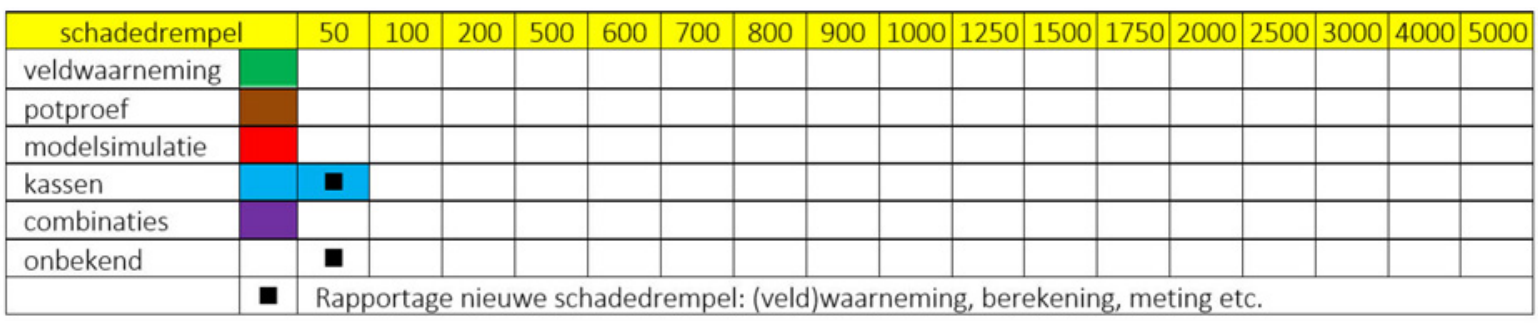

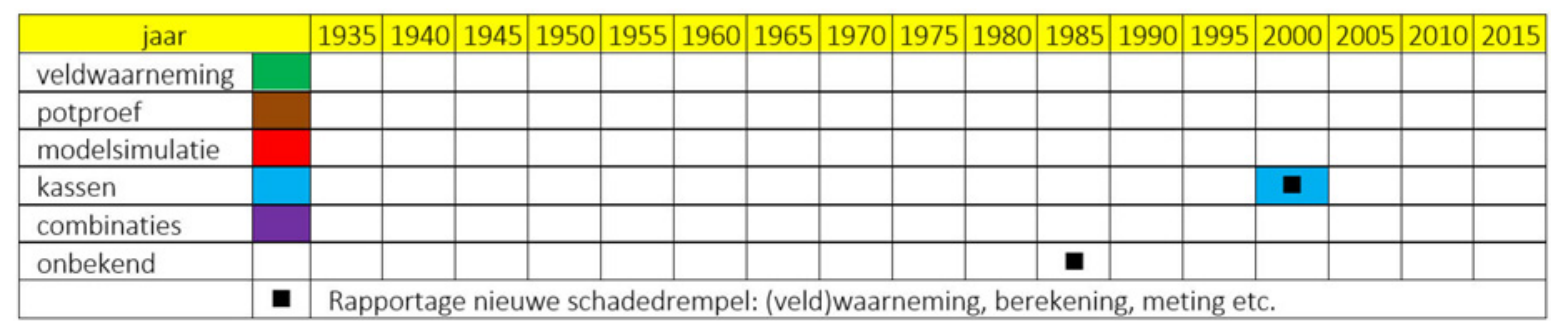

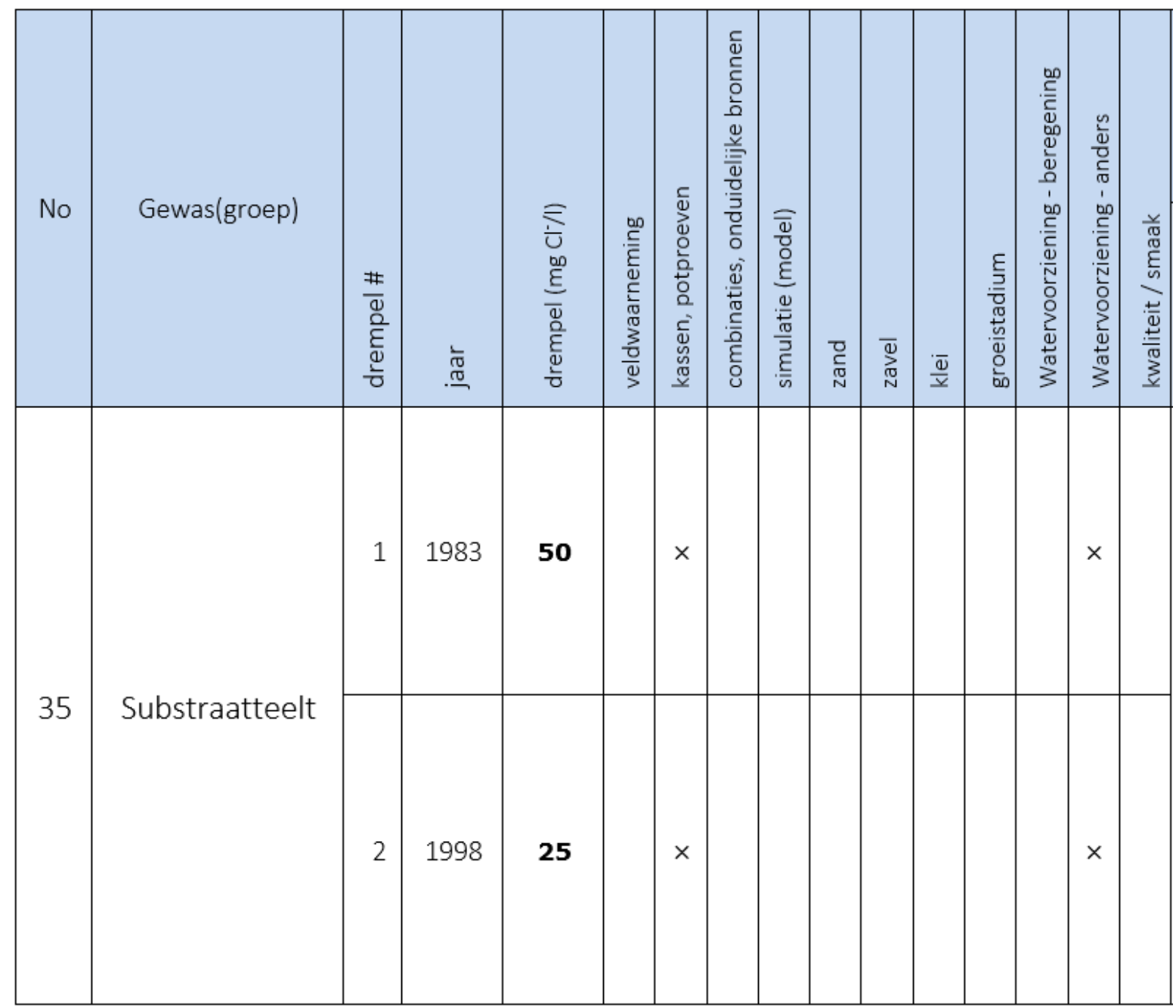



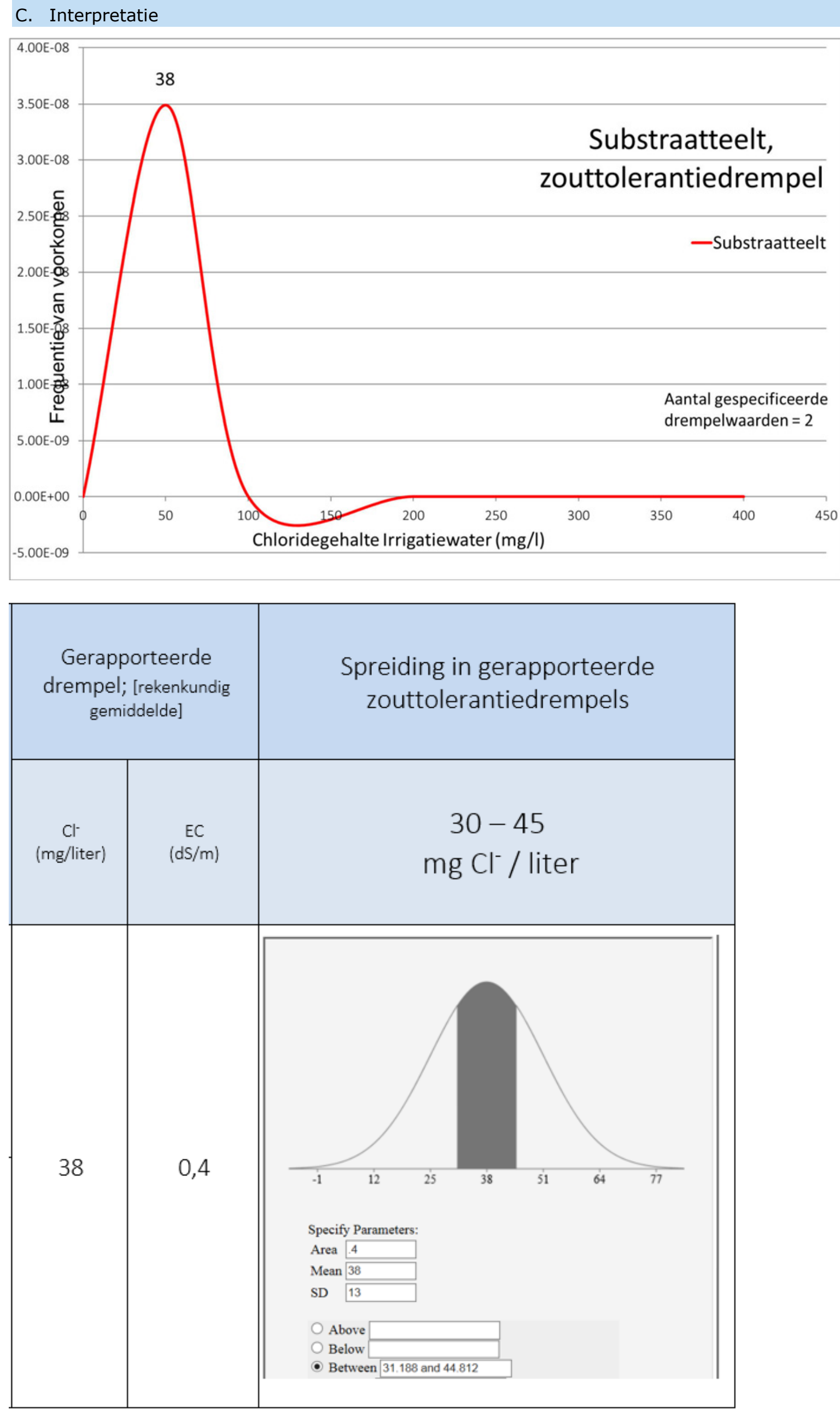


\section{Geraadpleegde bronnen}

Abell, L.F., 1954. De Zoutgevoeligheid van Zaadteeltgewassen. Ministerie van Landbouw, Visserij en Voedselvoorziening, Centrum voor Landbouwdocumentatie, Literatuurlijst 13, Staatsdrukkerij- en Uitgeverijbedrijf, 's-Gravenhage, $32 \mathrm{pp}$.

Abrahamse A.H., G. Baarse \& E. van Beek., 1982. Policy analysis of water management for the Netherlands. Vol.XII. Model for Regional Hydrology. Agricultural Water Demands and Damages from Drought and Salinity. Technical Report, RAND Corporation, Santa Monica, California, USA, $315 \mathrm{pp}$.

Aendekerk, Th.G.L.,1999. Adviesbasis voor de bemesting van boomkwekerijgewassen: pot en containerteelt. Boomteeltpraktijkonderzoek, Boskoop.

Aendekerk, Th.G.L., 2000. Adviesbasis voor de bemesting van boomkwekerijgewassen: vollegrondsteelt. Boomteeltpraktijkonderzoek, Boskoop.

Allen, R.G., L.S. Pereira, D. Raes and M. Smith, 1998. Crop evapotranspiration. Guidelines for computing crop water requirements. FAO Irrigation and drainage paper 56, Rome. http://www.kimberly.uidaho.edu/water/fao56/fao56.pdf

Ayers, R.S. and D.W. Westcott, 1985. Water Quality for agriculture. FAO Irrigation and drainage paper 29, Rome. http://www.water.ca.gov/wateruseefficiency/sb7/docs/FAO29-Chap2.pdf

Bakel P.J.T. van, R.A.L. Kselik, C.W.J. Roest en A.A.M.F.R. Smit. 2009. Review of crop salt tolerance in the Netherlands. Rapport 1926, Alterra, Wageningen.

Bakel, P.J.T. van, Linderhof, C.E. van 't Klooster, A.A. Veldhuizen, D. Goense, H.M. Mulder en H.T.L. Massop. 2009. Definitiestudie Agricom. Rapport 1934, Alterra, Wageningen.

Bakel, P.J.T. van en L.C.P.M. Stuyt, 2011. Actualisering van de kennis van de zouttolerantie van landbouwgewassen, op basis van literatuuronderzoek, expertkennis en praktische ervaringen. Wageningen, Alterra-rapport 2201.

Berg, C. van den, 1950a. De gevaren van toenemende verzilting voor land- en tuinbouw. Commissie voor Hydrologisch Onderzoek. Rijksdienst voor Landbouwherstel, Goes, Verslagen Technische Bijeenkomsten 1-6. p 262-268.

Berg, C. van den, 1950b. De reactie van landbouwgewassen op het zoutgehalte van de bodem. De inundaties gedurende 1944-1945 en hun gevolgen voor de landbouw. In: Verslagen van Landbouwkundige Onderzoekingen 56.16, 87 pp.

Berg, C. van den, 1952. De invloed van opgenomen zouten op de groei en productie van landbouwgewassen op zoute gronden. De inundaties gedurende 1944-1945 en hun gevolgen voor de landbouw. Deel XII. In: Verslagen van Landbouwkundige Onderzoekingen 58.5 - Doctoral thesis Landbouwhogeschool, Wageningen. Staatsdrukkerij Uitgeversbedrijf, 's-Gravenhage, 118 pp. http://edepot.wur.nl/176815

Berg, C. van den, 1959. Zoutgehalte. Mededeling Instituut voor Cultuurtechniek en Waterhuishouding No. 10 , Wageningen

Berg, C. van den, 1967. Tuinbouw en waterverontreiniging. Instituut voor Cultuurtechniek en waterhuishouding, Verspreide overdrukken 55, Med. Dir. Tuinb. p $113-122$. 
Bernstein, L., 1964. Salt tolerance of plants. USDA Agr. Inf. Bull no. 283.

Bierhuizen, J. F., en C. Ploegman, 1967. Zouttolerantie van tomaten. Med. Dir. Tuinb, 30. p 302-310.

Bik, A., 1969. Welke eisen moet men aan de kwaliteit van gietwater stellen. Vakblad voor de bloemisterij 24

Blom-Zandstra, M., W. Wolters, M. Heinen, C.W.J. Roest, A.A.M.F.R. Smit en A.L. Smit, 2014. Perspectives for the growth of salt tolerant cash crops. A case study with potato. Plant Research International, Part of Wageningen UR, Report no. 572. 36 p.

Blom-Zandstra, M. en J. Verhagen, 2015. Potato production systems in different agro ecological regions and their relation with climate change. Position paper, Wageningen UR, Business Unit Agro systems Research, Report 614. 32 p.

Blom-Zandstra, M., 2016. Informatie variabiliteit zouttolerantiewaarden. Overzicht van een aantal artikelen. Ongepubliceerde Memo, 2 p.

Boogerd, A. 2005. Van droge kennis naar natte natuur: de interactie tussen natuurwetenschap en beleid over verdroging. Eburon, Delft

Bruning, B., Katschnig, D., A.C. de Vos, M. van Rijsselberghe, R.A. Broekman en J. Rozema, 2011. Resultaten gewasteelt onder verschillende zoutbehandelingen op proefveld de Petten. Texel, Zilte teelt De Petten. Zilt Perspectief. 8 p.

Couwenhoven, T., 1971. De verzilting en het gebruik van sproeiwater in de akkerbouw. Bedrijfsontwikkeling 2, editie Akkerbouw. Instituut voor Cultuurtechniek en Waterhuishouding, Wageningen, p 53-63.

Cultuurtechnische vereniging, 1988. Cultuurtechnisch Vademecum. Utrecht, p 642-643.

Cultuurtechnisch Vademecum. Handboek voor inrichting en beheer van land water en milieu, 2000. Elsevier, Doetinchem, 1085 pp., paragraaf 4.3.3: Zoutschade.

Dam, J. G. C., 1953. Onderzoek naar de zoutgevoeligheid van de belangrijkste vollegronds groentegewassen. Med. Dir. Tuinbouw 17 nr. 10: 811-824.

Dam, A.M. van, O.A. Clevering, W. Voogt, Th.G.L. Aendekerk en M.P. van der Maas, 2007. Leven met Zout Water. Deelrapport Zouttolerantie van landbouwgewassen. Praktijkonderzoek Plant \& Omgeving BV (PPO) 32340194 00, p 36.

Deckers, S. en J. Vergote, 2006. Waterkwaliteit voor beregening. In: Landbouw \& Techniek 02 (27 januari 2006):36-37.

Dorsman, C. en M. Wattel, 1951. Zoutschade bij tuinbouwgewassen. De inundaties gedurende 19441945 en hun gevolgen voor de landbouw. Deel VII. Versl. Landbouwk. Onderz. 57.8, 54 pp.

Ende, J. van de, en C. Sonneveld, 1968. Zout gietwater bij kasteelt in West Nederland. Landbouwkundig tijdschrift, 80. p 348-353.

Ende, J. van de, 1970. Kwaliteitsnormen voor het gietwater. Bedrijfsontw. ed. Tuinbouw, 1. p 45-51.

Eurofins, 2015a. Waterkwaliteit in de akkerbouw. Bijlage/Toelichting. Eurofins Agro Laboratories, Wageningen.

Eurofins, 2015b. Waterkwaliteit in de boomkwekerij. Bijlage/Toelichting. Eurofins Agro Laboratories, Wageningen. 
Eurofins, 2015c. Waterkwaliteit in de fruitteelt. Bijlage/Toelichting. Eurofins Agro Laboratories, Wageningen.

Eurofins, 2015d. Waterkwaliteit in de glastuinbouw. Bijlage/Toelichting. Eurofins Agro Laboratories, Wageningen.

Eurofins, 2015e. Waterkwaliteit in de groenteteelt vollegrond. Bijlage/Toelichting. Eurofins Agro Laboratories, Wageningen.

FAO, 1976. Ayers, R.S. \& D.W. Westcot. Water quality for agriculture. Irrigation and Drainage Paper 48, FAO, Rome.

Feddes, R.A., P.J. Kowalik and H. Zaradny, 1978. Simulation of field water use and crop yield. Simulation Monographs. Wageningen: Pudoc.

Genuchten, M. Th. van \& G.J. Hoffman, 1984. Management Aspect for Crop Production. Chapter 8.1 Analysis of Crop Salt Tolerance Data. Springer, Berlin-Heidelberg. p 258-338.

Grieve, C.M., S.R. Grattan \& E.V. Maas. 2012. Plant salt tolerance. In: W.W. Wallender and K.K. Tanji. ASCE Manual and Reports on Engineering Practice No. 71. Agricultural Salinity Assessment and Management (2nd Edition), ASCE, Reston, VA, Chapter 13. p 405-459.

Heijden, P.G.M. van der, 2013. Development of integrated aquaculture - agriculture systems with brackish and salt water, Egypt. Centre for Development Innovation, Wageningen UR, Report CDI13-004. 64 p.

Hellings, A.J., 1971. Eisen inzake de kwaliteit van sproeiwater voor vollegrondsgroentegewassen. Mededeling 65. Bedrijfsontwikkeling 2: 4 april, editie tuinbouw, Proefstation voor de groenteteelt in de vollegrond in Nederland. p 31-37.

Heuer, B. \& A. Nadler, 1995. Growth and Development of potatoes under salinity and water deficit. Australian J. Agric. Res. 46. p 1477-1486.

Hissink, D.J., 1906. De chemische en physische inwerking van zout water op den bodem. In: Reprint Chemisch Weekblad 3, 9 pp.

Hissink, D.J., 1907a. Het Zoutgehalte van de op 12 Maart 1906 Ondergeloopen Zeeuwsche Polders. Van Langenhuysen, 's-Gravenhage, 29 pp.

Hissink, D.J., 1907b. De invloed van verschillende zoutoplossingen op het doorlatingsvermogen van den bodem. Chemisch Weekblad 4:663-673.

Hissink, D.J. 1954. De voorgeschiedenis van de verbetering van door zeewater bedorven gronden door bemesting met gips. In: Zuur, A.J. e.a. (Eds.) Langs gewonnen velden: Facetten van Smedings werk. Veenman \& Zn, Wageningen.

Hissink, D.J., Zijlstra, K., 1922. Verslag van het onderzoek naar de oorzaken vanden slechten stand van eenige gewassen in Zeeland. Verslagen van Landbouwkundige Onderzoekingen 27:1-12.

Hoogeveen, M.W., K.H.M. van Bommel en G. Cotteleer, 2003. Beregening in land- en tuinbouw. Rapport voor de Droogtestudie Nederland. Rapport 3.03.02. LEI, Den Haag. 64 p.

Hoorn, J.W. en J.W. van Alphen, 1994. Drainage Principles and Applications. Second Edition. ILRI Publication 16. Wageningen, The Netherlands, Chapter 15, Salinity Control. pp. 533-600.

Huinink, J.T.M., 1978. Waterkwaliteit en landbouwproductie. Ad Fundum, februari 1987. 
Huinink, J.T.M., 1987a. Waterkwaliteit en Landbouwproductie. CAD voor bodem-, Water en Bemestingszaken in de Akkerbouw en Tuinbouw, Wageningen.

Huinink, J.T.M., 1987b. Aantekeningen bij: Ad Fundum nr.4, februari 1987. Ongepubliceerd, 14 p.

Huinink, J.T.M. 1993. Bodemgeschiktheidstabellen voor landbouwkundige vormen van bodemgebruik. IKC-AT, Ede.

Huinink, J.T.M., 1998. Het economisch belang van water in de landbouw. Rapport Informatie- en Kennis Centrum Landbouw (IKC-Landbouw), Ede, p 26-27.

ICW, 1962. Jaarverslag van het Instituut voor Cultuurtechniek en Waterhuishouding. Mededeling ICW 48, Wageningen, p 11.

ICW, 1966. Jaarverslag van het Instituut voor Cultuurtechniek en Waterhuishouding (ICW). Wageningen.

ICW, 1968. Jaarverslag van het Instituut voor Cultuurtechniek en Waterhuishouding (ICW). Wageningen.

ICW, 1970. Jaarverslag van het Instituut voor Cultuurtechniek en Waterhuishouding (ICW). Wageningen.

ICW, 1971. Jaarverslag van het Instituut voor Cultuurtechniek en Waterhuishouding (ICW). Wageningen.

Jansen, P.C., 1983. Waterkwaliteit. Een beknopt overzicht van begrippen, parameters, typering en normen. Nota 1461 ICW, Wageningen, P 26-28.

Katschnig, D., J. Rozema en R. Broekman, 2014. Climate proof fresh water supply. Ongepubliceerde PowerPointpresentatie over klimaat adaptatie van gewassen aan droge(re) en zoute(re) omstandigheden. Kennis voor Klimaat - Vrije Universiteit Amsterdam, 32 pp.

Kroes, J.G., 2015. Ongepubliceerde Memo Logboek SWAP-berekeningen. SWAP-WOFOST toegepast in de Anna Paulownapolder. Een analyse met behulp van €ureyepener, 20 pp.

Landbouw Economisch Instituut. 1978. Vademecum voor de glastuinbouw. LEI, Den Haag.

Landbouw Economisch Instituut. 1977. Vademecum voor de tuinbouw in de open grond. LEI, Den Haag.

Landon, T.R. (1984). Booker tropical soil manual. Longman, London.

Langecker, W., S. Salem \& W. Bartolomeus, 1975. Untersuchungsergebnisse über die Auswirkung salzhaltigen Grundwassers auf Ertrag und Inhaltsstoffe von Gras-Klee-Gemischen. Archiv für Acker- und Pflanzenbau und Bodenkunde, Vol. 1975, 19(10):745-754.

Levy, D. \& G.C.C Tai, 2013. Differential response of potatoes (Solanum Tuberosum L.) to salinity in an arid environment and field performance of the seed tubers grown with fresh water in the following season. Agric. Water Managem. 116:122-127.

Locher, W.P. en H. de Bakker, 1990. Bodemkunde van Nederland. Deel 1, Algemene bodemkunde. Malmberg, Den Bosch.

Maas, E.V. (1990). Crop salt tolerance. http://www.ussl.ars.usda.gov/saltoler.htm 
Maas, E.V. and G.J. Hoffman, 1977. Crop salt tolerance-current assessment. J. Irrig. and Drainage Div., ASCE 103 (IR2):115-134.

Massop H. Th. L., C. Schuiling en A.A. Veldhuizen, 2013a. Buisdrainagekaart 2013. Update landelijke buisdrainagekenmerken t.b.v. NHI op basis van de landbouwmeitellingen 2010. Rapport 2381 Alterra, Wageningen.

Massop H. Th. L., C. Schuiling en A.A. Veldhuizen, 2013b. Potentiële beregeningskaart 2012. Update landelijke potentiele beregeningskaart t.b.v. NHI op basis van de landbouwmeitellingen 2010. Rapport 2382 Alterra, Wageningen.

Mayer, A., 1877. Verslag aan den Minister van Binnenlandse Zaken, Betreffende de Proefnemingen op door Zeewater Overstroomde Gronden. 18 pp.

Molen, W.H. van der, J.M. Beltran \& W.J. Ochs, 2007. Guidelines and computer programs for the planning and design of land drainage systems. FAO Irr. and Drain. paper 62. FAO Rome, p 230.

Munns, R. 2002. Comparative physiology of salt and water stress. Plant, Cell and Environment (2002) $25,239-250$.

Nieuwenhuizen, W., H.P. Wolfert, L.W.G. Higler, M. Dijkman, H.J. Huizinga, J. Kopinga, A. Makaske, B.S.J, Nijhof, A.F.M. Olsthoorn en J.H.M. Wösten, 2003. Standaardmethode Schade aan LNCwaarden als gevolg van overstromingen; methode voor het bepalen van de gevolgen van overstromingen voor de aspecten opgaande begroeiing, vegetatie, aquatische ecosystemen en historische bouwkunde. Alterra-rapport 709, Wageningen.

Nobel, C., 1921. De overstrooming van 13 en 14 Januari 1916 en haar gevolgen voor den landbouw in Waterland. In: Verslagen en Mededeelingen van de Directie van den Landbouw 1, pp. 26-51.

Ploegman, C., 1975. Invloed van infiltratie met chloridehoudend oppervlaktewater op het chloridegehalte in het bodemvocht en de productie bij tulpen. Nota 881 ICW, Wageningen, p 11.

Ploegman, C. en J.F. Bierhuizen, 1970. Zouttolerantie van komkommers. Bedrijfsontw. Ed. Tuinbouw, $1: 32-39$.

Ploegman, C., 1972. De invloed van zout beregeningswater bij de gladiool cv 'Peter Pears'. Nota 68, Instituut voor Cultuurtechniek en Waterhuishouding, Wageningen.

Ploegman, C., 1977. Waterkwaliteit en bloembollenteelt. Nota 954, Instituut voor Cultuurtechniek en Waterhuishouding, Wageningen.

Ploegman, C. en G.G.M. van der Valk, 1972. De invloed van zout beregeningswater op de ontwikkeling van vijf graden tulpen. C.V. Apeldoorn, Bedrijfsontwikkeling 3:1061-1063.

Ploegman, C., 1975. Invloed van infiltratie met chloridehoudend oppervlaktewater op het chloridegehalte in het bodemvocht en de productie bij tulpen. Rapport 881, ICW, Wageningen, $11 \mathrm{pp}$.

Ploegman, C., 1976. Invloed waterkwaliteit bij kasrozen. Rapport 913, ICW, Wageningen.

Ploegman, C., 1978. Het Chloride-ion in de grond in relatie tot de opbrengst bij tulpen. Landbouwkundig tijdschrift (1978) 90-2:40-43.

Ploegman, C. en J. Boontjes, 1981. Invloed van de zoutconcentratie van het bodemwater op de productie van drie leliecultivars. Nota 1248, Instituut voor Cultuurtechniek en Waterhuishouding, Wageningen. 
Ponse, H., 1808. Kleine Verhandeling over de Beste en Minst kostbare Middelen door Proeven Gestaafd, om de met Zout Water Overstroomd Geweest Zijnde klei-, Zand- als Veen Gronden, tot hunne Vorige Vruchtbaarheid te Herstellen. Met een Kort Voorberigt van J. v. Geervliet, 1808. Pols, Rotterdam.

Praktijkonderzoek Veehouderij, 1997. Handboek melkveehouderij. Uitgeverij Praktijkonderzoek Veehouderij, Lelystad:44.

Proefstation voor de Akkerbouw en de Groenteteelt in de Vollegrond., 1977. Kwantitatieve informatie voor de akkerbouw en groenteteelt. Lelystad.

Proefstation voor tuinbouw onder glas, Proefstation voor de bloemisterij en Informatie en Kenniscentrum, Afd. Glasgroente en bestuiving, 1991. Normen voor waterkwaliteit in de glastuinbouw. Serie Voedingsoplossingen glastuinbouw, No. 11, juli 1991.

Prummel, J., 1967. Nogmaals over chloorschade bij aardappelen (op kleigrond). Instituut voor Bodemvruchtbaarheid, Groningen, De Buffer 12(6):12-16.

Pulles, J.W., 1985. Beleidsanalyse voor de waterhuishouding in Nederland/PAWN. Rijkswaterstaat, 's-Gravenhage, pp.148, 153, 227,231.

Raats, P.A.C., 2014. Salinity management in the coastal region of the Netherlands: A historical perspective. Agric. Water Manage. 157:12-30. http://dx.doi.org/10.1016/j.agwat.2014.08.022

Rhoades, J.D., A. Kandiah and A.M. Mashali, 1992. The use of saline waters for crop production. FAO Irr. and Drain. Paper 48, FAO Rome. http://www.fao.org/docrep/T0667E/T0667E00.htm

Rhoades, J.D., F. Chanduvi and S. Lesch, 1999. Soil salinity assessment. Methods and interpretation of electrical conductivity measurements. FAO Irr. and Drain. Paper 57, FAO Rome.

ftp://ftp.fao.org/agl/aglw/docs/idp57.pdf

Riemens, J., 1941. Vraagstukken op het gebied der gezondheidstechniek, die aan het IJsselmeer verbonden zijn. Ingenieur.

Roest, C.W.J., P.J.T. van Bakel en A.A.M.F.R. Smit, 2003. Actualisering van de zouttolerantie van landen tuinbouwgewassen ten behoeve van de berekening van de zoutschade in Nederland met het RIZA-instrumentarium. Memorandum Alterra, Wageningen.

Rowaan, P.A., 1951. Overzicht van inundatie-onderzoek in Nederland tot 1944. De inundaties gedurende 1944-1945 en hun gevolgen voor de landbouw. Landbouwproefstation en Bodemkundig Instituut T.N.O. Verslagen van Landbouwkundige Onderzoekingen 57.3, 36 pp.

Rijkswaterstaat, 1968. De waterhuishouding van Nederland (1e Nota). Ministerie van Verkeer en Waterstaat, Staatsuitgeverij. 's-Gravenhage. $181 \mathrm{pp}$.

Rijtema, P.E., 1975. Water Quality Criteria for Agricultural Water Use. Nota 856 ICW, Wageningen.

Schipper, A. en J. van der Staak, 2011. Gietwater: let op ballastzouten en bicarbonaat. De Boomkwekerij 22 (3 juni 2011):8-9.

Shaterian, J., D. Waterer, H. De Jong en K.K. Tanino, 2005. Differential stress responses to NaCl salt application in early- and late maturing diploid potato (Solanum sp.) clones. Environ. Exp. Bot, 54:202-212.

Shannon, M.C. 1997. Adaptation of plants to salinity. Advances in Agronomy 60, 75-120. 
Shannon, M.C. \& C.M. Grieve, 1999. Tolerance of vegetable crops to salinity. Scientia Horticulturae 78:5-38.

Smeding, S., 1921. De overstrooming van den Anna-Pauwlownapolder in Januari 1916 en haar gevolgen voor den landbouw. In: Verslagen en Mededeelingen van de Directie van den Landbouw $1: 52-139$.

Snellen, W.B., 2012. Berekening Zoutschade. Ongepubliceerd Memorandum, Alterra. 9 pp.

Sonneveld, C. (1988). The salt tolerance of greenhouse crops. Netherlands Journal of Agricultural Science 36 (1988): 63-73.

Sonneveld, C. en J. van de Ende, 1969. De invloed van zout gietwater bij de slateelt onder glas. Tuinbouw Mededelingen 32:139-148.

Sonneveld, C. en J. van de Ende, 1971. De invloed van zout gietwater bij tomatenteelt onder glas. Bedrijfsontw. Ed. Tuinbouw 2:43-51.

Sonneveld, C. en J. van de Ende., 1974. De invloed van zout gietwater bij de teelt van peper en paprika onder glas. Landbouwk. Tijdschr. 86:41-246.

Stuyt, L.C.P.M., P.J.T. van Bakel, J.G. Kroes, E J. Bos, M. van der Elst, B. Pronk, P.J. Rijk, O.A. Clevering, A.J.G. Dekking, M.P.J. van der Voort, M. de Wol en W.A. Brandenburg, 2006. Transitie en toekomst van Deltalandbouw; indicatoren voor de ontwikkeling van de land- en tuinbouw in de Zuidwestelijke Delta van Nederland. Rapport 1132, Alterra, Wageningen.

Stuyt, L.C.P.M., 2009. Power point presentation 'Crop Salt Tolerance Workshop'. Wageningen. June 22, 2009. Alterra, Wageningen.

Stuyt, L.C.P.M., P.J.T. van Bakel en H.T.L. Massop, 2011. Basic Survey Zout en Joint Fact Finding effecten van zout. Naar een gedeeld beeld van het zoetwaterbeheer in laag Nederland. Rapport 2200, Alterra, Wageningen.

Stuyt, L.C.P.M., P.J.T. van Bakel, J. Delsman, H.T.L. Massop, R.A.L. Kselik, M.P.C.P. Paulissen, G.H.P. Oude Essink, M. Hoogvliet en P.N.M. Schipper, 2013. Zoetwatervoorziening in het Hoogheemraadschap van Rijnland. Onderzoek met hulp van €ureyeopener 1.0. Rapport 2439, Alterra, Wageningen.

Stuyt, L.C.P.M, C. Schuiling, P.J.T. van Bakel, H.T.L. Massop, G.H.P. Oude Essink, M. Faneca Sanchez, J. Velstra, N.B.P. Polman en A.C. de Vos, 2014. Mogelijke effecten van actualisatie van zoutschadefuncties van grondgebonden, beregende landbouwgewassen. KV-rapport 116/2014, ISBN 978-94-90070-82-3.

Stuyt, L.C.P.M., N. Kielen \& R. Ruijtenberg., 2015. Is de landbouw echt zo gevoelig voor zout water? Artikel in: Water Matters, Kenniskatern voor professionals, $\mathrm{H}_{2} \mathrm{O}$.

Stuyt, L.C.P.M., 2015. PowerPoint Zoet-Zout Platform. Burg Haamstede, 29 januari 2015.

Tanji, K.K. en N.C. Kielen, 2002. Agricultural drainage water management in arid and semi-arid areas. FAO Irr. \& Drain. Paper 61, FAO, Rome.

Thomas, R.G., 1973. Groundwater Models. FAO Irr. \& Drain. Paper 21 Rev. 1, FAO, Rome.

Valk, G.G.M. van der, 1970. Geschiktheid van zout oppervlaktewater voor beregening van tulpen.

Verhoeven, B., 1953. Over de zout- en vochthuishouding van geïnundeerde gronden. Proefschrift Landbouwhogeschool Wageningen. 
Visscher, C., 1979. De betrouwbaarheid van het pF-onderzoek in het laboratorium. Werkdocument, Rijksdienst voor de IJsselmeerpolders, Lelystad, $5 \mathrm{p}$.

Werkgroep Landbouwwatervoorziening Zoommeer Goes, 1987. Watervoorziening voor de landbouw uit het Zoommeer: onderzoeksrapport. Informatiecentrum, Provincie Zeeland.

Zijlstra, K., 1946. Over de gevoeligheid van eenige landbouwgewassen voor zeewater. Verslagen van Landbouwkundige Onderzoekingen 52(2):25-51. 
Wageningen Environmental Research Postbus 47

6700 AA Wageningen

T 0317480700

www.wur.nl/environmental-research

Wageningen Environmental Research

Rapport 2739

ISSN 1566-7197
De missie van Wageningen University \& Research is 'To explore the potential of nature to improve the quality of life'. Binnen Wageningen University \& Research bundelen Wageningen University en gespecialiseerde onderzoeksinstituten van Stichting Wageningen Research hun krachten om bij te dragen aan de oplossing van belangrijke vragen in het domein van gezonde voeding en leefomgeving. Met ongeveer 30 vestigingen, 5.000 medewerkers en 10.000 studenten behoort Wageningen University \& Research wereldwijd tot de aansprekende kennisinstellingen binnen haar domein. De integrale benadering van de vraagstukken en de samenwerking tussen verschillende disciplines vormen het hart van de unieke Wageningen aanpak. 



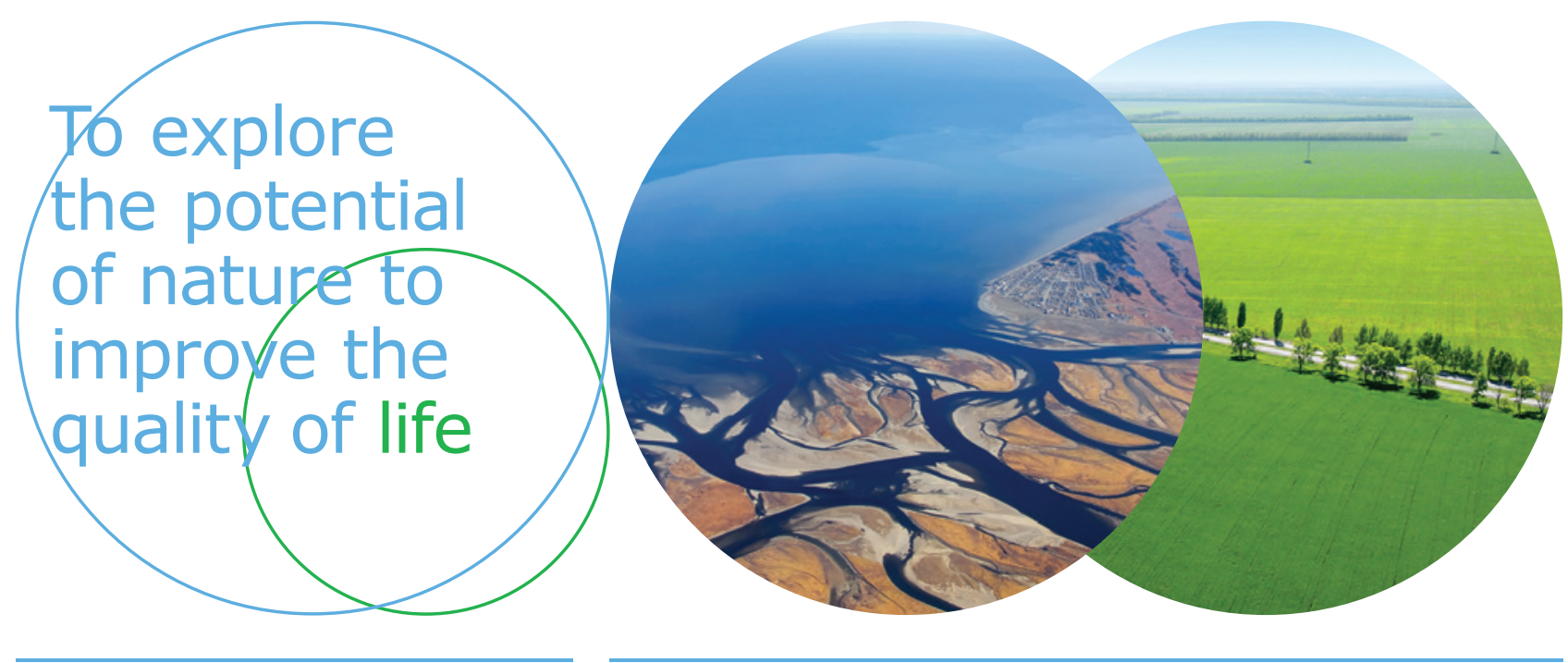

Wageningen Environmental Research Postbus 47

$6700 \mathrm{AB}$ Wageningen

T 317480700

www.wur.nl/environmental-research

Rapport 2739

ISSN 1566-7197
De missie van Wageningen University \& Research is 'To explore the potential of nature to improve the quality of life'. Binnen Wageningen University \& Research bundelen Wageningen University en gespecialiseerde onderzoeksinstituten van Stichting Wageningen Research hun krachten om bij te dragen aan de oplossing van belangrijke vragen in het domein van gezonde voeding en leefomgeving. Met ongeveer 30 vestigingen, 5.000 medewerkers en 10.000 studenten behoort Wageningen University \& Research wereldwijd tot de aansprekende kennisinstellingen binnen haar domein. De integrale benadering van de vraagstukken en de samenwerking tussen verschillende disciplines vormen het hart van de unieke Wageningen aanpak. 